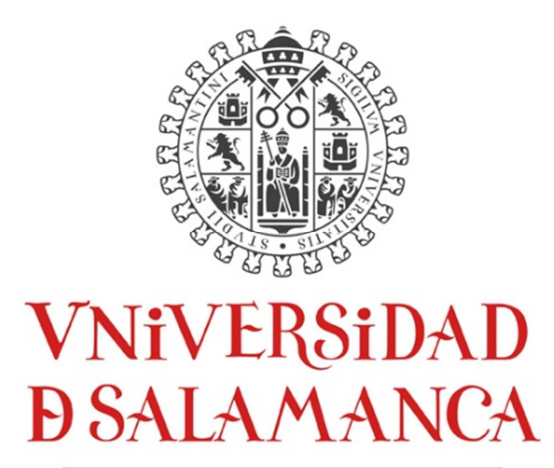

FACULTAD DE DERECHO

DEPARTAMENTO DE DERECHO ADMINISTRATIVO, FINANCIERO Y PROCESAL

\title{
EL NACIMIENTO DE LA DEUDA ADUANERA EN LA UNIÓN EUROPEA Y MÉXICO. ESTUDIO COMPARADO
}

SALAMANCA 2015

Tesis Doctoral presentada por el Lic. Carlos Gerardo Herrera Orozco bajo la dirección del Prof. Dr. José Antonio Chamorro y Zarza para la colación del Grado de Doctor en Derecho por la Universidad de Salamanca

Autor:

Director $($ V. $\stackrel{\circ}{B} . \stackrel{\circ}{)}$ : 



\section{Reconocimiento y agradecimientos:}

A mi esposa por su apoyo incondicional, paciencia, por seguirme literalmente al otro lado del mundo para que consiguiera mi sueño.

A mis hijos, por ser mi motor de vida.

A mis Padres por todo su apoyo.

A los ángeles de la guarda que Dios puso en mi camino en forma de amigos, que hicieron que a $9000 \mathrm{~km}$ de nuestro lugar de nacimiento, yo y mi familia nos sintiéramos en casa.

A Don Eusebio González (Q.E.P.D.).

A mi Director de Tesis, Dr. José Antonio Chamorro y Zarza por haber creído en este proyecto, su paciencia, buena dirección y amistad.

A todos mis profesores por su tiempo, consejos y valiosos conocimientos.

A las instituciones que tan cálidamente me albergaron para mis estancias de investigación.

Especial reconocimiento a la Universidad de Guadalajara, por la beca con la que me beneficio para poder realizar mis estudios de doctorado.

Sobre todo gracias a Dios por haberme puesto a todos Ustedes en mí camino. 
Carlos Gerardo Herrera Orozco 4 “El nacimiento de la deuda aduanera en la Unión Europea y México. Estudio comparado" 


\section{ÍNDICE}

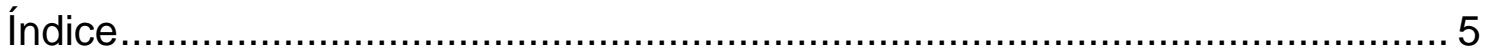

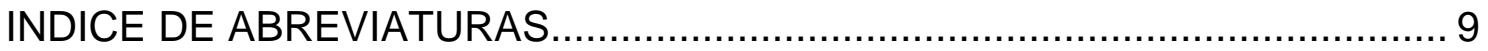

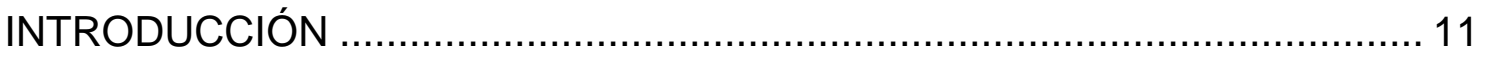

CAPITULO 1. EL DERECHO ADUANERO COMUNITARIO EUROPEO..........13

1.1. El Derecho primario y la atribución de competencias en la materia

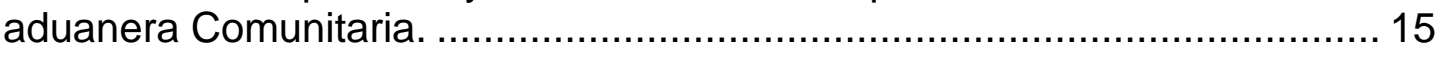

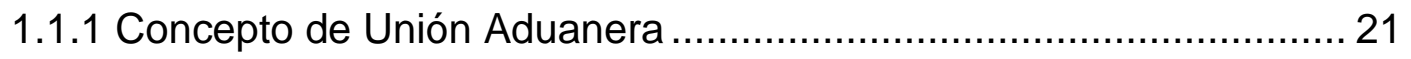

1.1.2 Elementos esenciales de la Unión Aduanera ............................... 28

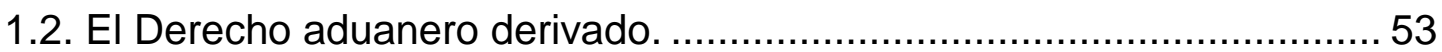

1.2.1. El Reglamento (CEE) no $2658 / 87$ del Consejo de 31 de diciembre de 1987, relativo a la nomenclatura arancelaria y estadística y al Arancel Aduanero Común. ............................................................................... 56

1.2.2. El Código Aduanero Comunitario y el Código Aduanero

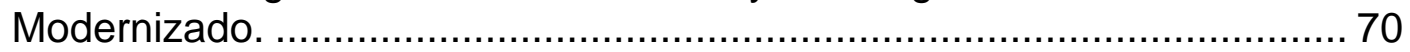

1.3. El Derecho aduanero de los Estados miembros.................................. 87

CAPÍTULO 2. El nacimiento de la deuda aduanera....................................... 99

2.1. El hecho imponible genérico del nacimiento de la deuda aduanera .... 107

2.2. Naturaleza jurídico-tributaria de los Derechos arancelarios................ 115

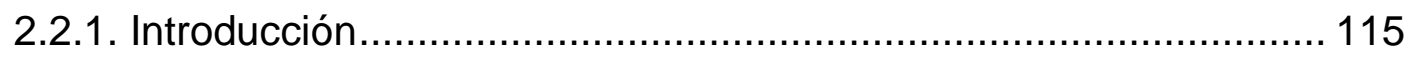

2.2.2. Los derechos arancelarios en su naturaleza jurídica de tasas por utilización de bienes de dominio público ................................................ 119

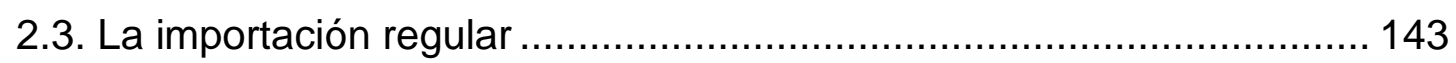

2.3.1. El despacho a libre práctica ............................................... 143

2.3.2. La importación temporal. Naturaleza jurídico-tributaria del cobro por incorporación de la mercancía al régimen de importación temporal. ....... 167

CAPÍTULO 3. LA DEUDA ADUANERA GENERADA POR IRREGULARIDADES

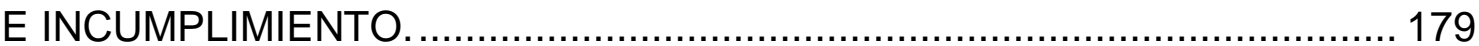

\subsection{EL NACIMIENTO DE LA DEUDA ADUANERA POR IMPORTACIÓN}

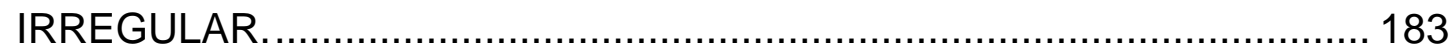

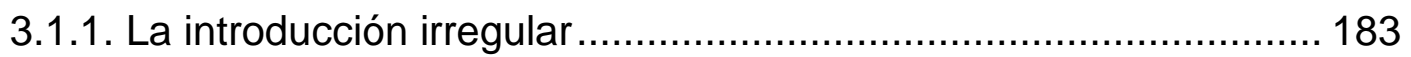

3.1.2. La sustracción a la vigilancia aduanera de una mercancía sujeta a derechos de importación .................................................................... 202

3.2. EL NACIMIENTO DE LA DEUDA ADUANERA POR INCUMPLIMIENTO.

3.2.1. La deuda aduanera por incumplimiento ................................... 207 
3.2.2. La deuda aduanera por consumo en zona franca 212 CAPÍTULO 4. EL DERECHO ADUANERO MEXICANO. 213

4.1. Antecedentes de la tributación aduanera en México......................... 215

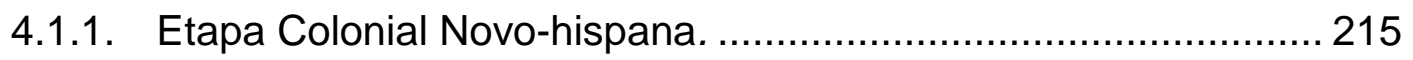

4.1.2. Periodo Post Independentista.................................................. 218

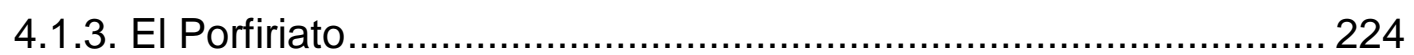

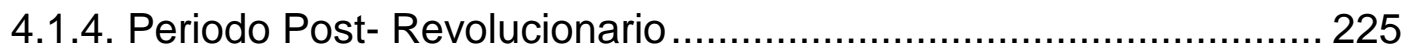

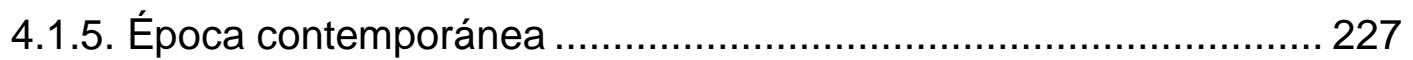

4.2. Fuentes y jerarquía de las normas aduaneras en México …................ 231

4.2.1. La Constitución. El control difuso de constitucionalidad................. 233

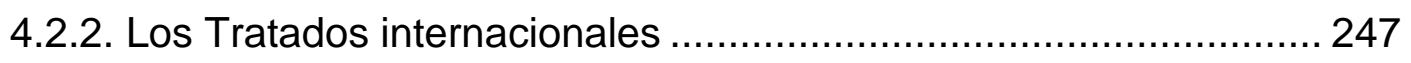

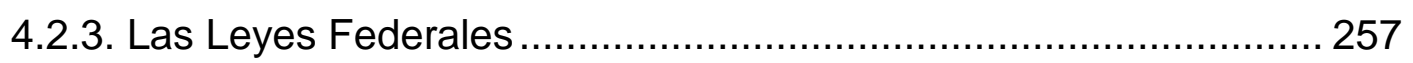

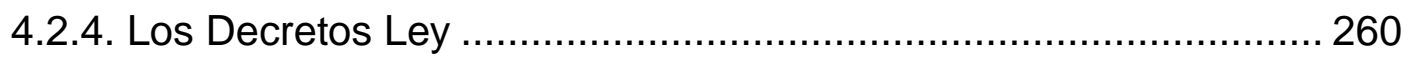

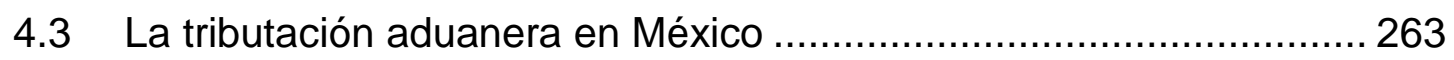

4.3.1. El hecho imponible genérico de la tributación aduanera en México y su naturaleza jurídico-tributaria.

4.3.2. La importación definitiva. La naturaleza jurídico-tributaria de los derechos arancelarios por importación definitiva.

4.3.3. La importación temporal.......................................................... 310

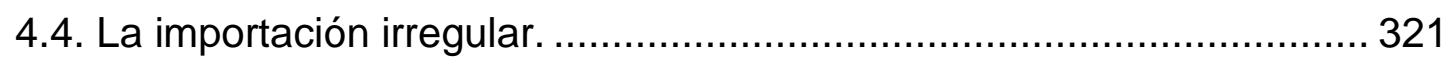

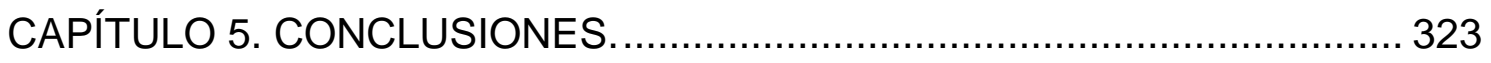

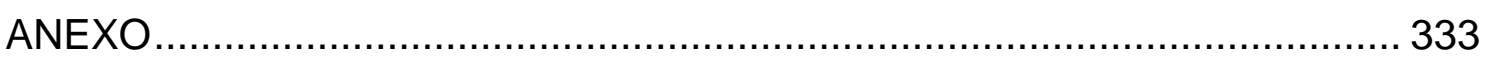

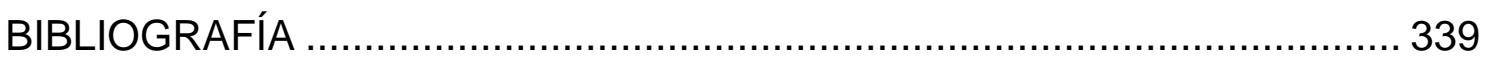

LIBROS:

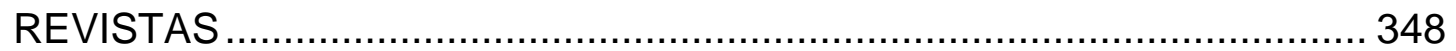

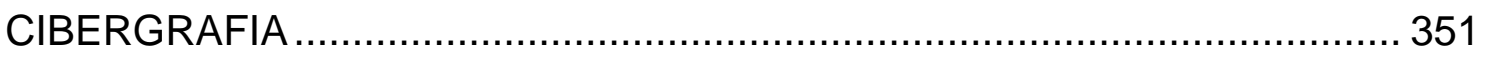

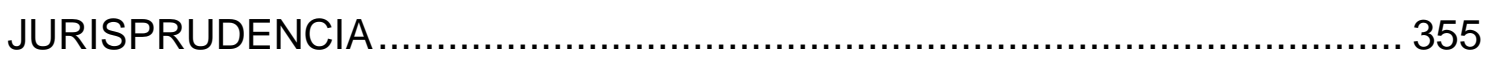

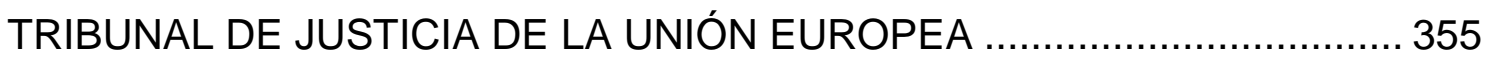

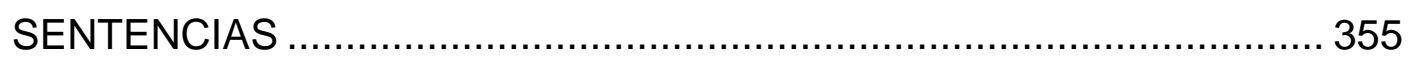

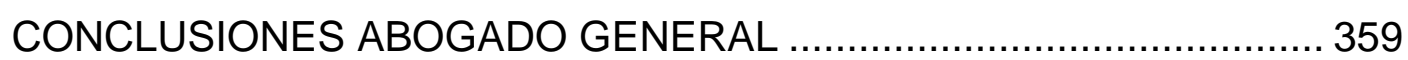

TRIBUNAL DE JUSTICIA DE PRIMERA INSTANCIA DE LA COMUNIDAD

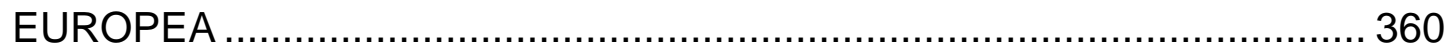

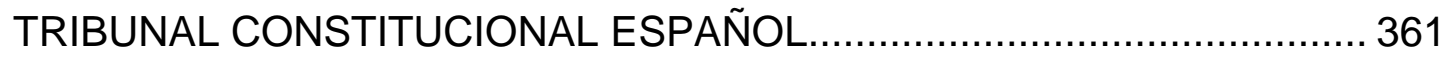

PODER JUDICIAL DE LA FEDERACIÓN (MÉXICO) ................................. 362

TRIBUNAL FEDERAL DE JUSTICIA FISCAL Y ADMINISTRATIVA (ANTES

TRIBUNAL FISCAL DE LA FEDERACIÓN) MÉXICO ................................... 364

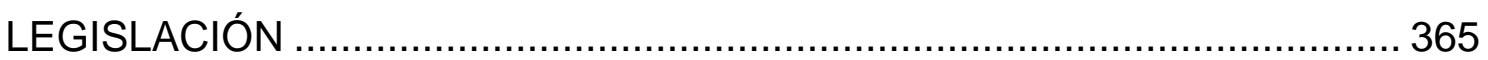


UNIÓN EUROPEA

365

ESTADOS MIEMBROS DE LA UNIÓN EUROPEA.

ESTADOS UNIDOS MEXICANOS 369

ACUERDOS CONJUNTOS UNIÓN EUROPEA - MÉXICO 370 TRATADOS, CONVENCIONES Y PROCEDIMIENTOS INTERNACIONALES 



\section{INDICE DE ABREVIATURAS}

AAC

ALADI

APPRIS

CA

CAM

CAU

CCA

CCP

CCT

CE

CEE

CPEUM

CVSDT

DDS

DDS

DOCE

DOF

EEE

GATT

IGI

LA

LGT

NC

OMA

OMA
Arancel Aduanero Común

Asociación Latinoamericana de Integración

Acuerdos para la Promoción y Protección

Recíproca de las Inversiones

Código Aduanero

Código Aduanero Modernizado

Código Aduanero de la Unión

Consejo de Cooperación Aduanera

Common Commercial policy

Common Customs Tariff

Comunidad Europea

Comunidad Económica Europea

Constitución Política de los Estados Unidos

Mexicanos

Convención de Viena Sobre el Derecho de los

Tratados

Sistema de Difusión de Datos

Sistema de Difusión de Datos

Diario Oficial de la Comunidad Europea

Diario Oficial de la Federación

Exacciones de Efecto Equivalente

Acuerdo General Sobre Comercio y Aranceles. Por sus siglas en Inglés $<<$ General Agreement On Tariffs And Trade >>

Impuesto General de importación

Ley Aduanera

Ley General Tributaria

Nomenclatura Combinada

Organización Mundial de Aduanas

Organización Mundial de Aduanas 


$\begin{array}{ll}\text { OMC } & \text { Organización Mundial de Comercio } \\ \text { OMC } & \text { Organización Mundial de Comercio } \\ \text { PAC } & \text { Política Agrícola Común } \\ \text { PCC } & \text { Política Comercial Común } \\ \text { PITEX } & \text { Programa de Importación Temporal para } \\ \text { RA } & \text { Producir Artículos de Exportación } \\ \text { REC } & \text { Reglamento Aduanero } \\ \text { SA } & \text { Recopilación } \\ \text { SCJN } & \text { Sistema Armonizado } \\ \text { STC } & \text { Suprema Corte de Justicia de la Nación } \\ \text { STJCE } & \text { Sentencia Tribunal Constitucional } \\ \text { STPI } & \text { Sentencia del Tribunal de Justicia de las } \\ & \text { Comunidades Europeas } \\ \text { TARIC } & \text { Sentencia Tribunal de Primera Instancia de la } \\ \text { TCE } & \text { Unión Europea } \\ \text { TFUE } & \text { "Tarif Integré des Communautés européennes" o } \\ \text { TIJ } & \text { arancel integrado de las comunidades europeas } \\ \text { TJCE } & \text { Tratado Comunidad Europea } \\ \text { TLC } & \text { Tratado de Funcionamiento de la Unión Europea } \\ \text { UE } & \text { Tribunal Internacional de Justicia } \\ & \text { Tribunal de Justicia de la Comunidad Europea } \\ & \text { Tratados de Libre Comercio } \\ & \text { Unión Europea }\end{array}$




\section{INTRODUCCIÓN}

El artículo 5 del "Acuerdo de Asociación Económica, Concertación Política y Cooperación entre los Estados Unidos Mexicanos y la Comunidad Europea y sus Estados Miembros", junto con el artículo 17 de la "Decisión 2/2000 del Consejo Conjunto Comunidad Europea - México", los cuales proponen un programa para establecer las divergencias y similitudes de ambos sistemas, para generar propuestas de aproximación de ambos sistemas aduaneros, fueron la inspiración para realizar esta tesis.

En ella realizamos un estudio crítico, descriptivo - analítico de los sistemas jurídicos aduaneros de la Unión Europea y México, con especial énfasis en el nacimiento de la obligación de pago del tributo aduanero, para al final del texto realizar un comparativo entre ambos sistemas y las propuestas de aproximación.

He de confesar que en muchas de las veces me vi rebasado por el tema de investigación, en donde tuve que formarme de forma extracurricular a mi programa de doctorado en diversas materias completamente nuevas para mí. El derecho aduanero europeo fue todo un reto, dada su complejidad por ser un sistema jurídico en desarrollo, que al estar inserto en el derecho comunitario europeo y la materia tributaria, se encuentra prácticamente abandonado, tanto por tributaristas, como por expertos en materia comunitaria, lo que se contrasta revisando la gran mayoría de las obras contemporáneas en materia de derecho aduanero, que son códigos aduaneros comentados. 
Son múltiples las anécdotas académicas y personales sucedidas a lo largo del proceso de elaboración de esta tesis, que de una u otra forma moldearon su forma actual, desde la incorporación del capítulo I, como resultado de los constantes debates en foros y con profesores respecto a las competencias de la Unión y de los Estados en materia de aduanas; así como la oportunidad de realizar estancias de investigación en Portugal y en la Comisión Europea, donde pude nutrir mi investigación de bibliografía y de entrevistas que me fueron de gran utilidad. Pese a las limitaciones de todo tipo que una investigación de estas características representa, quedo satisfecho con mi trabajo, pues considero aporto algo nuevo al Derecho tributario aduanero, sin dejar de ser consciente de que hay mucho que mejorar y que esto no es la culminación sino el inicio de mi vida como investigador. 


\section{CAPITULO 1. EL DERECHO ADUANERO COMUNITARIO EUROPEO}

El estudio de una figura jurídica especifica como es el nacimiento de la deuda aduanera requiere forzosamente el conocimiento del marco jurídico en el que se encuentra, máxime cuando la figura en estudio se encuentra inserta en un sistema jurídico en plena construcción y sin precedente alguno; en su estructura, re-jerarquización e impacto que tiene a nivel internacional como es el derecho comunitario europeo.

Por lo que iniciamos nuestro estudio de las normas básicas que componen el derecho aduanero comunitario. 



\subsection{El Derecho primario y la atribución de}

\section{competencias en la materia aduanera Comunitaria.}

La Comunidad Europea ${ }^{1}$ pese a sus singulares características que la distinguen de otras organizaciones internacionales ${ }^{2}$, al igual que cualquier otro organismo internacional limita sus actuaciones bajo el principio de atribución de competencias que se halla presente en los Tratados Constitutivos. El artículo 5 del Tratado de la Unión Europea (antiguo artículo 5 TCE) así como el artículo 13 del mismo Tratado limitan la actuación de la Comunidad a las competencias atribuidas en los Tratados y a los objetivos asignados.

Hasta antes de la entrada en vigor del Tratado de Lisboa y la consecuente entrada en vigor del Tratado de Funcionamiento de la Unión

\footnotetext{
${ }^{1}$ Aun cuando la abreviatura CE se utiliza regularmente en la doctrina española para referirse a la Constitución Española, nosotros la utilizaremos para referirnos a la Comunidad Europea, siguiendo la pauta de la "nota informativa sobre la cita de los artículos de los tratados en los textos del Tribunal de Justicia de las Comunidades Europeas y del Tribunal de Primera Instancia de las Comunidades Europeas", TJCE Nota de prensa 57/99 de 30 de julio de 1999.

${ }^{2}$ Diferencias que quedan expuestas en la célebre STJCE de 15 de Julio de 1964, asunto 6/64, caso: Flaminio Costa/ ENEL, REC. 1964, Volumen X, parte segunda, Pág.1158-1159, donde expone: "A diferencia de los Tratados internacionales ordinarios, el Tratado de la CEE creó un ordenamiento jurídico propio, integrado en el sistema jurídico de los Estados miembros desde la entrada en vigor del Tratado, y que vincula a sus órganos jurisdiccionales; que en efecto, al instituir una Comunidad de duración indefinida, dotada de Instituciones propias, de personalidad, de capacidad jurídica, de capacidad de representación internacional, y más en particular, de poderes reales derivados de una limitación de competencia o de una transferencia de atribuciones de los Estados a la Comunidad, éstos han limitado su soberanía, aunque en materias específicas, y han creado así un cuerpo normativo aplicable a sus nacionales y a sí mismos».
} 
Europea $^{3}$ (en adelante lo denominaremos TFUE), no existía un catálogo que delimitara cada uno de los ámbitos materiales y niveles de competencias Comunitarias, sino que éstas se encontraban dispersas por sus textos de forma específica o en función de los objetivos asignados a la Comunidad. Los artículos $3^{4}$ y 4 (Artículo 119 TFUE) CE otorgaban pautas generales de los campos sobre los que recae la acción comunitaria ${ }^{5}$, acciones que la mayor de las veces se trasladan al derecho positivo en forma de Políticas (o en parte de ellas) que no son otra cosa que marcos competenciales genéricos con distinto grado de participación comunitaria ${ }^{6}$.

\footnotetext{
${ }^{3}$ Desde el 1 de diciembre de 2009, fecha de entrada en vigor del Tratado de Lisboa: El título "Tratado constitutivo de la Comunidad Europea" se sustituye por "Tratado de Funcionamiento de la Unión Europea" (artículo 2, apartado 1, del Tratado de Lisboa).

${ }^{4}$ El apartado $1^{\circ}$ del artículo 3, fue derogado y sustituido, en sustancia, por los artículos 3 a 6 del TFUE. El apartado 2 es el actual artículo 8 del TFUE. Fuente. Tablas de correspondencias del TFUE. Diario Oficial de la Unión Europea de 9 de mayo de 2008 C-115/367.
}

${ }^{5}$ SÁENZ DE SANTA MARIA, P.A. GONZÁlEZ VEGA, J.A. y FÉRNÁNDEZ PÉREZ, B. Introducción al Derecho de la Unión Europea.1a Ed. Madrid: Eurolex, 1996. Pág. 105 Al referirse al sistema de atribución de competencias, dice: «Los Tratados operan con una técnica singular, enuncian en uno de sus artículos de la Parte General las acciones que deben emprender la Comunidad para la consecución de los objetivos del Tratado-artículo 3 TCE, por ejemplo- $y$ el resto de las disposiciones de índole material precisan el alcance, modalidad e intensidad de las atribuciones que se atribuye mediante los Tratados».

${ }^{6}$ LINDE PANIAGUA, E. "Fines y medios de las Comunidades Europeas. Los derechos fundamentales en la Unión Europea" en Políticas comunitarias. Madrid: Colex, 2001, Pág. 34 «El concepto de política en el contexto del Derecho de las Comunidades Europeas, nos remite, en primer término, a los ámbitos en que las Comunidades tienen competencias. Ámbitos competenciales, por tanto, que encierran títulos competenciales más o menos precisos, o de varios niveles» 
El Tratado de Funcionamiento de la Unión Europea, resuelve esta problemática y por primera vez determina los ámbitos, la delimitación y las condiciones de ejercicio de las competencias de la Unión Europea ${ }^{7}$. El artículo $2^{\circ}$ del TFUE establece los niveles, límites y forma en que se ejercen las competencias por parte de la Unión y de los Estados miembros. Entre las categorías de competencia el referido artículo establece tres niveles de competencia:

- Competencia Exclusiva: «Art. 2.1 TFUE. Cuando los Tratados atribuyan a la Unión una competencia exclusiva en un ámbito determinado, sólo la Unión podrá legislar y adoptar actos jurídicamente vinculantes, mientras que los Estados miembros, en cuanto tales, únicamente podrán hacerlo si son facultados por la Unión o para aplicar actos de la Unión».

- Competencia Compartida: «Art. 2.3 TFUE Cuando los Tratados atribuyan a la Unión una competencia compartida con los Estados miembros en un ámbito determinado, la Unión y los Estados miembros podrán legislar y adoptar actos jurídicamente vinculantes en dicho ámbito. Los Estados miembros ejercerán su competencia en la medida en que la Unión no haya ejercido la suya. Los Estados miembros ejercerán de nuevo su competencia en la medida en que la Unión haya decidido dejar de ejercer la suya».

\footnotetext{
${ }^{7}$ Artículo 1.1 TFUE. «El presente Tratado organiza el funcionamiento de la Unión y determina los ámbitos, la delimitación y las condiciones de ejercicio de sus competencias».
} 
- Competencia Subsidiaria: «Art. 2.5 TFUE. En determinados ámbitos y en las condiciones establecidas en los Tratados, la Unión dispondrá de competencia para llevar a cabo acciones con el fin de apoyar, coordinar o complementar la acción de los Estados miembros, sin por ello sustituir la competencia de éstos en dichos ámbitos».

Los artículos 352 y 353 TFUE fijan las directrices y límites para la aplicación de la competencia subsidiaria. Esta competencia, antes de la entrada en vigor del TFUE, estaba restringida en su aplicación únicamente a actos relativos al mercado único ${ }^{8}$, pues así lo establecía expresamente el artículo 308 CE (Artículos 352 y 353 TFUE). Sin embargo el propio texto de los artículos 2.5 y 352 TFUE, no hacen mención expresa para su aplicación a determinada política, más sí excluye expresamente su aplicación en los ámbitos de "política exterior y de seguridad común”, así como en los casos establecidos por el artículo 353 TFUE.

En cuanto a las materias que están comprendidas dentro de las categorías señaladas por el artículo 2ํㅡ, vienen listadas según la categoría que ocupan. El artículo 3ำTFUE agrupa aquellas materias en las que la Unión Europea tiene competencia exclusiva; y el artículo 4ํㅡ TFUE las competencias compartidas

\footnotetext{
${ }^{8}$ Para el Glosario de la Unión Europea las Competencias subsidiarias son aquellas: «cuando no existe competencia explícita o implícita para lograr algún objetivo del Tratado relacionado con el mercado único, el artículo 308 del Tratado constitutivo de la Comunidad Europea permite al Consejo adoptar por unanimidad las medidas que considere oportunas». http://europa.eu/scadplus/glossary/community_powers_es.htm

${ }^{9}$ Artículo 352.4 TFUE
} 
entre la Unión Europea y los Estados miembros. Las materias comprendidas en la categoría de las competencias subsidiarias serán aquellas en las que no se hayan previsto los poderes de acción necesarios ${ }^{10}$, es decir materias distintas a las listadas en los artículos 3 y 4 del TFUE.

Dada la naturaleza del derecho aduanero comunitario, la generalidad y la interrelación de las competencias de las Políticas de la Comunidad, su regulación se encuentra inmersa en varias políticas comunitarias de distinta categoría competencial entre las que destacan: la Unión aduanera (competencia exclusiva) $^{11}$ y la política comercial común (competencia exclusiva $)^{12}$.

En el presente trabajo no nos detendremos a examinar detenidamente cada una de ellas dada la generalidad de competencias y temas que engloban, lo cual nos desviaría del tema principal de esta investigación y sobrepasaría con mucho los objetivos perseguidos, por lo cual nos centraremos únicamente en aquellos puntos cuya relevancia incide directamente en el tema de nuestra investigación.

\footnotetext{
${ }^{10}$ Artículo 352.1 "Cuando se considere necesaria una acción de la Unión en el ámbito de las políticas definidas en los Tratados para alcanzar uno de los objetivos fijados por éstos, sin que se hayan previsto en ellos los poderes de actuación necesarios a tal efecto, el Consejo adoptará las disposiciones adecuadas por unanimidad, a propuesta de la Comisión y previa aprobación del Parlamento Europeo. Cuando el Consejo adopte dichas disposiciones con arreglo a un procedimiento legislativo especial, se pronunciará también por unanimidad, a propuesta de la Comisión y previa aprobación del Parlamento Europeo».

${ }^{11}$ Artículo 3.1 a) TFUE

${ }^{12}$ Artículo 3.1 e) TFUE
} 
Por otro lado, al hablar del Derecho primario y de la atribución de competencias a un ámbito determinado como lo es la materia aduanera comunitaria, es necesario partir de un concepto esencial aunque amplio de Unión aduanera y los elementos que la componen, aspectos que se analizarán a continuación. 


\subsubsection{Concepto de Unión Aduanera}

El artículo 28.1 TFUE (antiguo Art. 23 del Tratado CE) prescribe lo siguiente: «La Unión comprenderá una Unión aduanera, que abarcará la totalidad de los intercambios de mercancías y que implicará la prohibición, entre los Estados miembros, de los derechos de aduana de importación y exportación y de cualesquiera exacciones de efecto equivalente, así como la adopción de un Arancel Aduanero Común en sus relaciones con terceros países».

Este artículo declara así la importancia de la Unión aduanera como fundamento de la comunidad y de los principios básicos en los que se sustenta: la eliminación de obstáculos al comercio intracomunitario (derechos de aduana, exacciones de efecto equivalente y restricciones cuantitativas) y el establecimiento de un Arancel Aduanero Común en sus relaciones con terceros países $^{13}$. En términos generales es lo más aproximado a una definición de Unión aduanera que otorga el Tratado $\mathrm{CE}$, sin que contenga todos los elementos que integran la Unión aduanera comunitaria.

\footnotetext{
${ }^{13}$ Prueba de ello es que antes del Tratado de Ámsterdam existía la división del capítulo de la Unión aduanera en dos secciones tituladas: "supresión de los derechos de aduana entre los Estados miembros" y "Establecimiento de un Arancel Aduanero Común". Tras la entrada en vigor del Tratado de Ámsterdam el 1 de mayo de 1999, se suprimen las secciones y se derogan 15 de los 18 artículos de que constaba el capitulo. Por lo cual el capítulo de la Unión aduanera en el tratado de CE estaba formado únicamente por los artículos: 25 CE (antiguo Art.12), 26 CE (antiguo Art. 28) y 27 CE (antiguo Art. 29). Los artículos referidos pasaron íntegramente al TFUE, siendo actualmente los artículos 30, 31 y 32.
} 
El punto primero del Entendimiento relativo a la interpretación del artículo XXIV del Acuerdo General Sobre Aranceles Aduaneros y Comercio de 1994, establece que «Para estar en conformidad con el artículo XXIV, las uniones aduaneras, las zonas de libre comercio y los acuerdos provisionales tendientes al establecimiento de una Unión aduanera o una zona de libre comercio deberán cumplir, entre otras, las disposiciones de los párrafos 5, 6, 7 y 8 de dicho artículo».

Es decir, que para considerarse la existencia de una Unión aduanera deben de darse los siguientes elementos:

1. Sustituir dos o más territorios por un solo territorio aduanero;

2. Eliminar los derechos de aduana y demás reglamentaciones comerciales restrictivas al intercambio comercial entre los Estados miembros ${ }^{14}$;

3. Aplicar a las importaciones procedentes de terceros países «derechos de aduana y demás reglamentaciones del comercio que, en substancia, sean idénticos» ${ }^{15}$, y cuya implantación no se traduzca en un incremento en los derechos de aduana y mayor

\footnotetext{
${ }^{14}$ El párrafo 8, no pone como requisito la eliminación total de los derechos de aduanas y restricciones comerciales al comercio entre Estados miembros, sino que éstas deberán al menos eliminarse, en lo que concierne a lo esencial de los intercambios comerciales de los productos originarios de dichos territorios, lo que como veremos más adelante resulta una diferencia importante con la concepción de Unión Aduanera actual.

${ }^{15}$ GATT 1947, Artículo XXIV 8 a ii)
} 
rigor en la normativa comercial, en relación a la aplicada antes de su puesta en marcha; siempre y cuando dichos aumentos no sean resultado de: una carga equivalente a un impuesto interior no discriminatorio, un derecho antidumping o compensatorio ajustado a las reducciones efectuadas en el derecho correspondiente de los demás territorios constitutivos de la Unión y/o derechos u otras cargas proporcionales al costo de los servicios prestados.

4. Las partes contratantes previa integración a la Unión aduanera, deberán proporcionar toda la información necesaria que les permita a las otras partes contratantes evaluar la viabilidad de la Unión y formular las recomendaciones que estimen pertinentes, debiendo informar cualquier modificación que pueda comprometer o diferir indebidamente el establecimiento de la Unión aduanera.

La Organización Mundial de Aduanas (OMA) retoma estos puntos y define de manera más concreta las Uniones aduaneras ${ }^{16}$, definición que si se

\footnotetext{
${ }^{16}$ World Customs Organization. Glossary of international customs terms. Brussels: 2006, Pág.13 "Customs Union: Entity forming a Customs territory replacing two or more territories and having in its ultimate state the following characteristics : - a common Customs tariff and a common or harmonized Customs legislation for the application of that tariff; - the absence of any Customs duties and charges having equivalent effect in trade between the countries forming the Customs Union in products originating entirely in those countries or in products of other countries in respect of which import formalities have been complied with and Customs duties and charges having equivalent effect have been levied or guaranteed and if they have not benefited from a total or partial drawback of such duties and charges.- the elimination of restrictive regulations of commerce within the Customs Union". Hemos preferido sujetarnos a esta definición para realizar la comparación, en virtud de la idoneidad de la fuente al ser un
} 
compara con el artículo 28 TFUE, se comprueba que coinciden en cuanto a las características de la aplicación de un Arancel Aduanero Común y en la eliminación de gravámenes a la importación, más echaremos en falta en el texto del artículo 28 TFUE dos características básicas contempladas por la definición de la Organización Mundial de Aduanas: la prohibición de restricciones cuantitativas y la mención de la armonización de la normativa aduanera para la aplicación del arancel.

Esta presunta omisión por parte del TFUE no obscurece en nada la esencia de la Unión aduanera comunitaria, pues esas omisiones en el artículo 28 TFUE se encuentran reguladas en otros artículos del TFUE, de forma implícita o expresa. Verbigracia la prohibición de restricciones cuantitativas se encuentra legislada en el capítulo 2 del mismo TITULO II (Arts. 34 a 37 TFUE), en tanto la armonización de la normativa aduanera de los Estados miembros se considera ya superada con la adopción en 1968 del Arancel Aduanero Común, el establecimiento en 1992 del Mercado interior y la entrada en vigor en el mismo año del Código Aduanero Comunitario ${ }^{17}$, razón por la cual se deroga por el Tratado de Ámsterdam el antiguo artículo 27 del Tratado CE (Artículo anterior al tratado de Ámsterdam $)^{18}$ que preveía la armonización paulatina de la

organismo internacional especializado en la materia, además de ser una definición más actual y concisa que la proporcionada por el GATT.

${ }^{17}$ Reglamento CEE 2913/92 Del Consejo, de 12 de octubre de 1992.

${ }^{18}$ Artículo 27 del Tratado CEE «Antes de finalizar la primera etapa, los Estados miembros procederán, en la medida necesaria, a la aproximación de sus disposiciones legales, reglamentarias y administrativas en materia aduanera. La comisión dirigirá, a ese fin, las pertinentes recomendaciones a los Estados miembros". 
legislación aduanera. No obstante lo anterior y aun cuando existen múltiples Directivas vigentes que pretenden lograr una armonización integral en la materia, no se han logrado armonizar del todo las normas aduaneras relativas a la gestión y recaudación cuya competencia fue delegada a los Estados miembros como veremos más adelante.

El artículo 207 TFUE (antiguo artículo 133 TCE) vela por la uniformidad de principios relativos al intercambio comercial con terceros países, como pueden ser las modificaciones arancelarias, la celebración de acuerdos arancelarios y comerciales, medidas de liberalización, políticas de exportación, medidas de protección comercial, dumping y subvenciones, en los que se basa la Política Comercial Común. Este artículo es, a mi parecer, el verdadero vínculo entre la política comercial común y la Unión aduanera, más aun que la declaración de intenciones formulada en el artículo 206 TFUE (antiguo 131 CE), pues es en base al $133 \mathrm{CE}$ por el que se han establecido la mayoría de las normas aduaneras de la CE y del que nos ocuparemos en párrafos siguientes.

El Tribunal de Justicia de las Comunidades Europeas en su sentencia de 13 de diciembre de 1973, caso "Fondo de diamantistas", define la Unión aduanera comunitaria, conservando la esencia y estructura del artículo $23 \mathrm{CE}$, pero a la vez, desarrollando aquellas características esenciales que considerábamos omitidas por este artículo, en comparación con la definición de la Organización Mundial de Aduanas. Así el TJCE en la sentencia antes citada, se refiere a la Unión aduanera de la siguiente forma: «Considerando que la Unión aduanera, fundamento de la Comunidad, implica, por una parte, la supresión, entre los 
Estados miembros, de los derechos de aduana y de cualesquiera exacciones de efecto equivalente; que dicha supresión pretende hacer efectiva la libre circulación de productos dentro de la Comunidad; que por lo tanto, debe ser completa, de manera que se supere cualquier obstáculo, económico, administrativo o de otro tipo, para poder lograr la unidad de mercado entre los Estados miembros; considerando que la Unión aduanera implica, por otra parte, el establecimiento de un Arancel Aduanero Común para el conjunto de la Comunidad, como prevén los artículos 18 a 29 del Tratado; que dicha comunidad arancelaria pretende lograr la equiparación de las cargas aduaneras que gravan los productos importados de países terceros en las fronteras de la Comunidad, con el fin de evitar cualquier desviación del tráfico comercial en las relaciones con dichos países y cualquier distorsión en la libre circulación interna o en las condiciones de competencia» ${ }^{19}$.

De los razonamientos anteriores, podemos considerar tres elementos esenciales de la Unión aduanera comunitaria, que tomaremos como esquema para comprender el porqué de la competencia exclusiva de la UE en esta materia:

- La supresión de todos los derechos de aduana y las restricciones entre los Estados miembros.

- La creación de un Arancel Aduanero Común (AAC), aplicable en toda la Comunidad Europea a las mercancías procedentes de terceros países.

\footnotetext{
${ }^{19}$ STJCE de 13 de diciembre de 1973, asuntos acumulados 37 y 38/73, caso FONDO DE DIAMANTISTAS. RC. 1973, tomo II Págs. 1609 a 1626.
} 


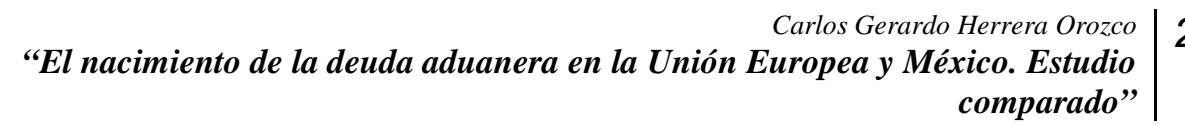

- La política comercial común como componente externo de la Unión aduanera.

A estos elementos nos referiremos a continuación. 


\subsubsection{Elementos esenciales de la Unión Aduanera}

\subsubsection{La supresión de los derechos de aduana y las restricciones al tráfico de mercancías entre los Estados miembros.}

El primero de los tres elementos esenciales de la Unión aduanera a los que hacíamos alusión anteriormente se corresponde íntegramente con la acción prevista por el derogado ${ }^{20}$ inciso a) del artículo $3.1 \mathrm{CE}^{21}$, cuyo fin perseguido es lograr la unidad de mercado entre los Estados miembros, como apuntaba la antes citada STJCE de 13 de diciembre de 1973.

Esta acción se traslada a la esfera del derecho positivo en la parte Tercera del Tratado CE, titulada "Políticas de la Comunidad", hoy conocida en el TFUE como "Políticas y acciones internas de la Unión", en específico en el Título denominado: "Libre circulación de mercancías"22. Éste regula en el Capítulo 1, denominado "Unión aduanera", lo relativo a "la supresión entre los Estados miembros de los derechos de aduana de importación y exportación o

${ }^{20}$ El Tratado de Lisboa deroga el apartado $1^{\circ}$ de este artículo; sustituyéndolo en sustancia por los artículos 3 a 6 del TFUE. Fuente: Tabla de correspondencias artículo 5 Tratado de Lisboa, nota al pie de página 26.

${ }^{21}$ Artículo 3 CE «1. Para alcanzar los fines enunciados en el artículo 2, la acción de la Comunidad implicará, en las condiciones y según el ritmo previstos en el presente Tratado:

a) la prohibición, entre los Estados miembros, de derechos de aduana y de restricciones cuantitativas a la entrada y salida de las mercancías, así como de cualesquiera otras medidas de efecto equivalente».

${ }^{22}$ Título I en el Tratado CE, hoy Título II en el TFUE. 
exacciones de efecto equivalente" en tanto "la prohibición de restricciones cuantitativas" se regula en el Capítulo 2 del mismo nombre ${ }^{23}$.

a) La supresión entre los Estados miembros de los derechos de aduana de importación y exportación o exacciones de efecto equivalente.

"La supresión entre los Estados miembros de los derechos de aduana de importación y exportación o exacciones de efecto equivalente" se trata en el actual artículo 30 TFUE, antiguo artículo $25 \mathrm{CE}^{24}$ que sufrió modificaciones tras el Tratado de Ámsterdam, concentrando en el texto del artículo los principios de la antigua "sección primera" del Capítulo de la Unión aduanera ${ }^{25}$. La supresión de derechos de aduana entre los Estados miembros no representó problema alguno, ya que la entrada en vigor del Arancel Aduanero Común conllevó la eliminación de los aranceles nacionales.

No ocurrió lo mismo con la supresión de las exacciones de efecto equivalente dada su indefinición en el TCE, por lo que el TJCE tuvo que intervenir a efectos de definirla y marcar sus límites. El Tribunal establece que

\footnotetext{
${ }^{23}$ Cabe resaltar que tras el tratado de Lisboa no existió modificación en torno a la numeración de los capítulos citados.

${ }^{24}$ «Artículo 30 TFUE. Quedarán prohibidos entre los Estados miembros los derechos de aduana de importación y exportación o exacciones de efecto equivalente. Esta prohibición se aplicará también a los derechos de aduana de carácter fiscal».

${ }^{25}$ La sección primera estaba constituida en su mayoría por disposiciones transitorias de eliminación progresiva de gravámenes al comercio intracomunitario, que quedaron rápidamente superadas y que requerían por lo tanto una nueva reglamentación
} 
«una carga pecuniaria, aunque sea mínima, impuesta unilateralmente, cuales quiera que sean su denominación y su técnica, que grave las mercancías nacionales o extranjeras a su paso por la frontera, cuando no sea un derecho de aduana propiamente dicho, constituye una exacción de efecto equivalente, en el sentido de los artículos 9 y 12 del Tratado, aunque no sea percibido en beneficio del Estado, ni ejerza ningún efecto discriminatorio o proteccionista y aunque el producto gravado no haga competencia a una producción nacional» ${ }^{26}$.

Otra de las modificaciones efectuadas por el Tratado de Ámsterdam al artículo 25 CE y que persiste en el actual artículo 30 TFUE, es la de hacer extensiva la prohibición de establecimiento de derechos de aduana a "los derechos de aduana de carácter fiscal”, según lo contemplaba el artículo 17 del Tratado CEE (Derogado por el Tratado de Ámsterdam). Prohibición que justifica la jurisprudencia del TJCE a fin de prever fallos ante prácticas fiscales o aduaneras que pudieran obstaculizar la libre circulación de mercancías ${ }^{27}$. Los redactores de los Tratados Constitutivos y el TJCE, no consideran que los derechos de aduana de carácter fiscal estén automáticamente incluidos en el

26 STJCE de 1 de Julio de 1969, asuntos acumulados 2/69 y 3/69, caso Fondo de Diamantistas. (Rec. 1969, Pág. 211 y siguientes).

${ }^{27}$ Ver al respecto a la diferenciación STJCE de 1 de Julio de 1969, asuntos acumulados 2/69 y 3/69, caso Fondo de Diamantistas. (Rec. 1969, Pág. 211 y siguientes) Consideraciones 8 y 9. "que es tal la fuerza de éstas prohibiciones, que para evitar que sean soslayadas por prácticas aduaneras o fiscales, ha querido prevenir cualquier posible fallo en su puesta en práctica; que el artículo 17 precisa, en dicho sentido, que las prohibiciones del artículo 9 serán aplicables incluso si los derechos de aduana tienen carácter fiscal;'». 
concepto de derechos de aduana ${ }^{28}$, y retoman la clasificación de los derechos de aduana en "protectores" o "fiscales", según sea el fin perseguido: "salvaguarda de la producción nacional frente a las importaciones" o "recaudatorio", respectivamente ${ }^{29}$. Clasificación que no está exenta de

${ }^{28}$ STPI de 22 de enero de 1997, asunto T-115/94, caso Opel Austria GmbH contra Consejo de la Unión Europea. (Fuente: CURIA) «112. Sobre este extremo, procede, en primer lugar, desestimar el argumento de la Comisión consistente en alegar que, teniendo en cuenta que del artículo 10 del Acuerdo EEE se deduce que no se considera que los derechos de aduana de carácter fiscal estén automáticamente incluidos en el concepto de derechos de aduana de importación y exportación y exacciones de efecto equivalente, dicho artículo y las disposiciones correspondientes del Tratado CE no son sustancialmente idénticos. En efecto, basta con recordar que el Tratado CE contiene una disposición correspondiente, a saber, el artículo 17 del Tratado, artículo que precisa que las prohibiciones del artículo 9 del Tratado serán aplicables aunque los derechos de aduana tengan carácter fiscal y cuyo objeto es evitar que se eluda la prohibición de los derechos de aduana de importación y exportación y de cualesquiera exacciones de efecto equivalente».

${ }^{29}$ Ver al respecto ALBIÑANA GARCÍA, C. Sistema tributario español y comparado. Madrid: Tecnos, 1992. Pág. 551. «Son fiscales cuando se proponen proporcionar recursos a la Hacienda Pública (para financiar los gastos públicos). Y protectores cuando restringen la entrada de mercancías extranjeras (cuando no la impiden) y estimulan o protegen la producción nacional, puesto que evitan la competencia de los artículos o mercancías de producción extranjera». BERR, C.J. y TRÉMEAU, H. Le droit douanier Communautaire et national. 6” Ed. Paris: Editorial Economica, 2004. Pag. 87 "La distinction des droit de douane à caractère fiscal et des autres ne présente aujourd'hui qu'un intérêt historique, dans la mesure où elle ne touchait qu'à l'établissement de I union tarifaire : partant de l'idée que certains droits qualifiés de droits de douane n'ont en réalité pour but que d'alimenter les Trésors nationaux et ne visent pas à protéger des productions intenes (cas des droits sur le café, le thé et les épces, par exemple), les rédacteurs du traité de Rome invitaient les États à les supprimer tout en autorisant à les remplacer par des taxes intérieures (taxe de consommation, taxe unique, etc.)». CUtRera, A. Principi di diritto e politica Doganale. Padova: CEDAM, 1941. Pág. 183 "Quanto allo scopo i dazidoganalisi distinguono in: a)dazi fiscali, se destinati exclusivamente a procurare un'entrata alla publica finanza; b) dazi economici se, indipendentemente dall' entrache essi procurano all'erario, vengono stabiliti con il propositodi giovare alla industria nazionale». DATTOLA, S. Istituzioni di diritto e tecnica doganale. Milan: A. Giuffrè, 1983. Pág. 13 «Fiscali: quelli diretti esclusivamentea procurare un'entrata financiaría. Economici, quelli diretti a 
polémica, prueba de ello es que ante la dificultad de diferenciación entre fiscalidad y proteccionismo del ya citado artículo 17 del Tratado CE (Anterior al tratado de Ámsterdam), se estipulaba que los Estados miembros debían de hacer del conocimiento de la Comisión sus derechos de aduana de carácter fiscal.

Actualmente hay quien considera que los derechos aduaneros han perdido esa doble finalidad quedando afianzados en su fin proteccionista ${ }^{30}$, posición con la cual discrepo pues no considero que exista esa separación: en primer lugar la cita utilizada por GALERA RODRIGO ${ }^{31}$ para sustentar su posición no

promuover o proteggere determinati rami di produzione». DI LORENZO, M. Corso di diritto doganale. Vol. I. 1ª Ed. Milan: Dott. A. Giuffré editore, 1947, Pág. 140 "Sono dazi fiscali quelli stabiliti per assicurare un provento finanziario allo Stato, ed appunto perció essi sono fissati sempre in misura elevata, perché gravano su merci che non possono essere prodotte nell'interno dello Stato, per ragioni naturali o di convenienza commerciale; onde non vi é alcun pericolo che possano esercitare una influenza dannosa alla vita economica del Paese». LEITE DE CAMPOS, D. "O Mercado comum europeu e a instituçao de barreiras tarifarias ou comopensatorias". En TAVEIRA TORRES, H. Comercio internacional e tributaçao. $1^{\circ} \mathrm{Ed}$. Sao Paulo: Qaurtier Latin, 2005, Pág. 595 "os direitos aduaneiros de carácter fiscal, ou seja, aqueles que se aplicam aos productos importados, mesmo na ausencia de productos similares ou comparáveis no mercado interno, e que visam a, esencialmente, gerar receitas fiscais para as autoridades públicas».

${ }^{30}$ GALERA RODRIGO, S.Derecho Aduanero Español y Comunitario: La Intervención Pública sobre el Comercio Exterior de Bienes, 1르 Ed. Madrid: Civitas, 1995. Pág. 105 «Creemos que la tradicional doble finalidad recaudatoria y proteccionista reconocida a los impuestos $y$ gravámenes aduaneros ha cedido paso a la finalidad de afirmar la finalidad proteccionista de los mismos. Desde esta perspectiva, el nacimiento de deuda aduanera es la necesaria consecuencia del instrumento seleccionado para la intervención».

${ }^{31}$ IBIDEM.cita pie de página 20 [La evolución de la finalidad de estas figuras impositivas, y la progresiva importancia de su carácter protector en F.A. BREÑA CRUZ, «La imposición sobre la la Circulación de Bienes», en la obra colectiva Teoría de la Hacienda Pública, Escuela de Inspección Financiera y Tributaria, Ministerio de Hacienda, 1982 (Pág. 203), quien afirma que 
se refiere a la desaparición del fin recaudatorio, sino a su pérdida de primacía frente al fin proteccionista; en segundo lugar la STJCE ${ }^{32}$ que utiliza como "prueba irrefutable" del fin proteccionista de los derechos aduaneros, no marca de ninguna forma un fin netamente proteccionista, sino simplemente señala "la entrada de la mercancía en el circuito económico de la Comunidad", como el hecho gravado por el tributo, ó lo que es lo mismo su hecho imponible. Por lo que el razonamiento que hace posteriormente no es en torno a su finalidad sino a su naturaleza tributaria, temas de los que nos ocuparemos en otro capítulo. Independientemente de lo anterior basta con observar los considerandos de algunos reglamentos comunitarios para constatar la presencia de la finalidad recaudatoria, al estipular el pago de los derechos aduaneros como elemento a salvaguardar y de forzosa aplicación para la entrada de mercancías en el circuito económico de la Comunidad ${ }^{33}$.

estos impuestos «...pierden importancia recaudatoria a medida que los países se desarrollan... constituyen valiosos instrumentos de regulación indirecta del comercio exterior»].

32 STJCE de 05 de Octubre de 1983, asuntos acumulados 186 y 187/82, caso MinisteroDelleFinanze contra EsercizioMagazzini Generali S.P.A. Y Mellina Agosta S.R.L. (REC. 1983 Págs. 02951).

${ }^{33}$ Ejemplos:

Reglamento (CE) № 82/97 del Parlamento Europeo y del Consejo de 19 de diciembre de 1996 que modifica el Reglamento (CEE) n²913/92 por el que se aprueba el Código aduanero comunitario «3) Considerando que se debe garantizar en todos los casos que las mercancías obtenidas a partir de mercancías no comunitarias incluidas en un régimen suspensivo no entren en el circuito económico de la Comunidad sin pagar derechos a la importación,...».

Reglamento (CE) n 3665/93 de la Comisión de 21 de diciembre de 1993 por el que se modifica el Reglamento (CEE) n²454/93 por el que se fijan determinadas disposiciones de aplicación del Reglamento (CEE) n²913/92 del Consejo por el que se establece el Código aduanero 
Otra posición doctrinal en sentido totalmente opuesto a la anterior, es la expuesta por RAPOSO DE MADEIROS ${ }^{34}$, quien reconoce la interrelación de ambas finalidades, así como la distinción de uno u otro fin en relación a su primacía, ejemplificando con algunos supuestos identificadores de la finalidad perseguida. El autor considera que la mayoría de los derechos de exportación son de carácter netamente fiscal salvo en aquellos casos en que: recaigan sobre mercancías que es necesario tratar de impedir su salida hacia terceros países o que se trate de materias primas necesarias para la industria nacional. En el caso de los derechos de aduana a la importación considera que tendrán carácter exclusivamente fiscal en aquellos supuestos en que recaigan sobre productos que no se produzcan en el territorio, o en aquellos casos en los que los derechos arancelarios sean iguales a los impuestos indirectos cobrados a mercancías similares de producción interna.

comunitario. "Considerando que se ha puesto de manifiesto que los Estados miembros aplican reglas divergentes relativas a la situación aduanera de las mercancías abandonadas en beneficio del Tesoro Público o decomisadas o confiscadas por las autoridades competentes; que mientras dichas mercancías no sean despachadas a libre práctica, una deuda aduanera sigue siendo susceptible de nacer al respecto; que conviene, por lo tanto, dictar disposiciones comunitarias con el fin de garantizar que las mercancías no entren en el circuito económico de la Comunidad sin pagar los derechos a la importación".

${ }^{34}$ RAPOSO DE MADEIROS, E. O dereito aduaneiro sua vertente internacional. Lisboa: Instituto superiores de ciências sociais y políticas, 1985. Pág. 16. "Quando se aplicam directos de exportação, estes têm normalmente uma naturaleza fiscal, exceptuando-se todavía dois casos: quando incidem sobre produtos em que é necesario obstar à sua saida para terceiros países;quando inciden sobre matérias-primas que fazem falta à transformação industrial nacional. Os directos de importação são de naturaleza exclusivamente fiscal quando: incidem sobre mercadorias que não são producidas no interior do territorio;são iguais aos impostos indirectos cobrados para mercadorias similares de produçao interna». 
En primer lugar debemos conceptuar el contexto temporal de la obra y el cambio de políticas económicas a nivel mundial, en las que se pretende fomentar la exportación, llevando a la casi desaparición de los derechos arancelarios y a una inversión de las proporciones aludidas por RAPOSO DE MADEIROS. Así, los pocos derechos arancelarios a la exportación que subsisten, en su mayoría por no decir en su totalidad inciden en los supuestos considerados por el autor con fines proteccionistas, no obstante no dejan de reportar ingresos a las arcas comunitarias. En lo tocante a los derechos de la importación es necesario analizar por separado los dos supuestos planteados por el autor.

En el primero de los supuestos a primera vista resulta bastante lógica la interpretación de atribuir carácter fiscal a los derechos de aduana que recaigan sobre productos que no se produzcan en el territorio aduanero, pues allí no habría producción interna que "proteger" por lo cual la finalidad en teoría sería netamente recaudatoria, aunque no es siempre así: pongamos el ejemplo de una mercancía que efectivamente no se produzca en el territorio aduanero, pero cuyas características la hagan susceptible de entrar en una relación de competencia, aunque sea parcial, indirecta o potencial con algún producto de la Comunidad. En caso de ser gravada, el derecho arancelario no sería netamente fiscal, al estar protegiendo indirectamente a otros productos originarios de la Comunidad $^{35}$, por lo que, bajo estos supuestos, la

\footnotetext{
35 Ver al respecto las sentencias del TJCE de 27 de febrero de 1980 y 12 de julio de 1983 (Comisión contra Reino Unido, 170/78, Rec. 1980, p. 417, y Rec. 1983, p. 2265); así como la sentencia 9 DE JULIO DE 1987. - Comisión de las Comunidades Europeas contra el Reino de Bélgica. - Régimen fiscal del vino y de la cerveza. - asunto 356/85. Las cuales aun cuando
} 
exclusividad del fin recaudatorio en los derechos a la importación se reduciría a contadas mercancías de origen vegetal o mineral que no pudieran entrar en competencia con algún producto comunitario.

Si aplicáramos el segundo de los supuestos, daría como resultado que la totalidad de los derechos aduaneros en la CE son de carácter fiscal, en tanto la totalidad de las mercancías importadas a los territorios de la Comunidad se encuentran gravadas por impuestos indirectos en identidad de condiciones que los productos comunitarios de su segmento. Lo que corrobora la inviabilidad de tratar de separar la fiscalidad y parafiscalidad de los derechos de aduana pues, como hemos visto en estos ejemplos, ambos fines no se manifiestan en exclusividad ya que el derecho de carácter fiscal, en la mayor parte de la veces, estará protegiendo directa o indirectamente un producto determinado, en tanto que los derechos de carácter protector aun cuando su función es desincentivar una importación o exportación y/o equiparar los precios respecto a los productos nacionales, terminan reportando ingresos a las arcas comunitarias. Así, la distinción entre uno y otro fin estará de acuerdo a la primacía del fin perseguido y no a la separación entre ambos.

\section{b) La prohibición de restricciones cuantitativas}

La eliminación de las restricciones cuantitativas no ofrece mayor problemática doctrinal y de aplicación dado que, al igual que los derechos de aduana, se entienden superadas con la entrada en vigor de la Unión aduanera, 
siendo lo más destacable al respecto las excepciones establecidas en el artículo 36 TFUE (antiguo artículo 30 TCE), las cuales se rigen por los principios de salvaguarda del orden público, moral, seguridad, salud, preservación de la flora y fauna, así como la protección del patrimonio histórico y cultural. Estas excepciones se aceptan siempre y cuando no sean discriminatorias o constituyan una restricción encubierta del comercio entre los Estados miembros.

La relevancia de estas prohibiciones para nuestro tema, aparte de lo anteriormente expuesto, radica en la armonización normativa que llevan emparejada, al regular el contenido sustantivo de las normas que rigen el comercio exterior imponiendo la obligación a los Estados miembros de eliminar de su legislación los derechos de aduana, exacciones de efecto equivalente y restricciones cuantitativas al tráfico comercial intracomunitario ${ }^{36}$. Esto, junto al establecimiento de un Arancel Aduanero Común frente al exterior, constituye una cesión de competencias en la materia a favor de la CE que se materializa, como ya vimos anteriormente, en el artículo $3^{\circ}$ del TFUE.

\subsubsection{El establecimiento del Arancel Aduanero Común y la Política Comercial Común.}

\footnotetext{
${ }^{36}$ Entendiendo por tal no únicamente lo relativo al comercio de mercancías comunitarias sino también respecto a las mercancías que se encuentran en libre practica de conformidad a lo establecido en el punto 2 del artículo $23 \mathrm{CE}$.
} 
El objetivo fundamental del Arancel Aduanero Común en términos del TJCE, es uniformizar las cargas aduaneras, impedir la desviación del tráfico comercial y la distorsión en la libre circulación de mercancías en las condiciones de competencia ${ }^{37}$, lo cual sin duda tiene una gran importancia desde la perspectiva económica y también desde la perspectiva jurídica, pues el establecimiento del Arancel Aduanero Común conlleva la implantación de un nuevo orden jurídico comunitario, como veremos en párrafos subsecuentes.

El Arancel Aduanero Común es una de las primeras normas aduaneras comunitarias de aplicación prioritaria, directa y de observancia general para todos los Estados miembros, pues si bien es cierto que al momento del establecimiento del Arancel Aduanero Común, los principios de primacía, aplicación directa y observancia general de los reglamentos comunitarios ya estaban vigentes $^{38}$, también lo es que hasta antes del 28 de junio de $1968^{39}$ la

${ }^{37}$ STJCE de 05 de octubre de 1995, caso Aprile, asunto C- 125/1994, Rec. 1995, párrafo 32 «... un Arancel Aduanero Común que tiene por objeto la consecución de la igualdad de los gravámenes que soportan en las fronteras exteriores de la Comunidad los productos importados de países terceros, para evitar toda desviación de tráfico en las relaciones con dichos países y toda distorsión en la libre circulación de los productos entre los Estados miembros o en las condiciones de competencia entre los operadores económicos».

${ }^{38}$ Ver al respecto de la primacía del derecho comunitario la STJCE de 9 de marzo de 1978, caso: Simmenthal, asunto 106/77, Rec. 1978 ,Considerando 17: «Que por lo demás, en virtud del principio de primacía del Derecho comunitario, las disposiciones del Tratado y los actos de las instituciones directamente aplicables tienen por efecto, en sus relaciones con el Derecho interno de los Estados miembros, no sólo el hacer inaplicable de pleno derecho, por el hecho mismo de su entrada en vigor, toda disposición contraria de la legislación nacional existente, sino también - en cuanto que estas disposiciones y actos forman parte integrante, con rango de prioridad, del ordenamiento jurídico aplicable en el territorio de cada uno de los Estados miembros-, el impedir la adopción válida de nuevos actos legislativos nacionales en la medida en que éstos fueran incompatibles con normas comunitarias». 
generalidad de la regulación aduanera estaba regida por Directivas y/o Acuerdos.

El establecimiento del Arancel Aduanero Común, lleva aparejada la concesión de la competencia exclusiva al Consejo para la determinación de los derechos arancelarios, dotando implícitamente ${ }^{40}$ por este medio de una competencia

El fallido Tratado de Constitución Europea, recopilaba el principio de primacía del derecho comunitario en su Artículo I- 6 titulado "Derecho de la Unión". Inexplicablemente el texto no se reproduce en el TFUE, por lo que la jurisprudencia antes citada sigue siendo un referente inequívoco de este principio. En cuanto a la aplicación directa y observancia general de los reglamentos, ya estaba dispuesto en el artículo 189 del Tratado C.E.E. actual artículo 288 TFUE. No está por demás ver algunos señalamientos doctrinales al respecto. MANGAS MARTÍN, A. y LIÑAN NOGUERAS, D. Instituciones y Derecho de la Unión Europea, Ob. Cit. P. 344 «EI TJCE ha ido elaborando una construcción coherente y sin fisuras reconociendo a un gran número de normas de los Tratados la capacidad de producir efectos directos sobre los particulares, cuando naturalmente la norma tiene ese carácter incondicional y formula con claridad y precisión la obligación o el Derecho». KLAUS-DIETER BORCHARDT. El ABC del Derecho Comunitario.5 ${ }^{\text {a }}$ ed. Luxemburgo: Oficina de Publicaciones Oficiales de las Comunidades Europeas, 2000. P. 23 «al Derecho creado por el Tratado, nacido de una fuente autónoma, no se puede oponer, en razón de su específica naturaleza original una norma interna, cualquiera que sea ésta, ante los órganos jurisdiccionales, sin que al mismo tiempo aquél pierda su carácter comunitario y se ponga en tela de juicio la base jurídica misma de la Comunidad [...]la transferencia realizada por los Estados, de su ordenamiento jurídico interno en favor del comunitario, de los derechos y obligaciones correspondientes a las disposiciones del Tratado, entraña por tanto una limitación definitiva de su soberanía, contra la que no puede prevalecer un acto unilateral ulterior incompatible con el concepto de Comunidad». En tanto lo relativo a la obligatoriedad y aplicación directa del derecho derivado lo consagra titulado "Actos jurídicos de la Unión".

${ }^{39}$ EI ARANCEL ADUANERO COMÚN fue adoptado originalmente mediante Reg. 950/68 del Consejo de 28 de junio de 1968, derogado el 31 de diciembre de 1987 y sustituido por el actual ARANCEL ADUANERO COMÚN mediante Reg. 2658/87 del Consejo de 23 de julio de 1987.

${ }^{40}$ VER MANGAS MARTÍN, A. y LIÑAN NOGUERAS. Instituciones de Derecho de la Unión Europea. Ob. Cit. Pág. 215 «En virtud de la doctrina de los poderes implícitos se admite que una OI (organización internacional), además de las competencias expresamente atribuidas, 
material para regular el correcto funcionamiento de la Unión aduanera. Al ostentar la capacidad de fijar los derechos arancelarios, por lógica lo hace también para regular aquellos rubros que se derivan de dicho establecimiento $^{41}$, excluyendo con ello cualquier competencia de los Estados

puede disponer de las competencias que sean necesarias, incluso nuevas, para la realización de los Objetivos fijados por el Tratado constitutivo, o sean esenciales al ejercicio de las funciones asignadas a la Ol». MARTÍN Y PÉREZ DE NANCLARES, J. "Las competencias comunitarias". En: LÓPEZ ESCUDERO, M. MARTÍN Y PÉREZ DE NANCLARES, J. y OTROS. Derecho comunitario material. 1aㅡ Ed. Madrid: Mc. Graw Hill, 2000. P.17. «En virtud de la denominada teoría de los poderes implícitos (impliedpowers), asumida con anterioridad por el TPJI (Tribunal Permanente de Justicia Internacional) y por el TIJ (Tribunal Internacional de Justicia), las organizaciones internacionales gozarán también de aquellas competencias no expresamente atribuidas por el Tratado fundacional que resulten indispensables $y$ absolutamente necesarias para el eficaz ejercicio de sus funciones». Un ejemplo de reconocimiento de poderes implícitos en nuestra materia lo encontramos en el Dictamen 1/75 de fecha 11 de Noviembre de 1975, mediante el cual el TJCE reconoce competencia a la Comunidad para la celebración de acuerdos internacionales en materia de créditos a la exportación.

${ }^{41}$ Ver al respecto las Conclusiones del Abogado General Sr. Alberto Trabucchi, presentadas el 27 de Junio de 1973, asunto 8/73, caso HAUPTZOLLAMT BREMERHAVEN / MASSEY FERGUSON. RC. 1973, tomo I, Pág. 913 y 914 «la potestad de dirigir la Unión aduanera, que implica en particular la de fijar y modificar los derechos del Arancel Aduanero Común (art. 28 del Tratado), también debe comprender necesariamente la facultad de adoptar las normas que, por afectar directamente a elementos básicos de la materia, son precisas para el correcto funcionamiento de la propia Unión aduanera. Esta consideración podría bastar para reconocer que la potestad de la Comunidad de regular el valor en aduana de las mercancías se deduce del conjunto de facultades y competencias que corresponden a la Comunidad en materia aduanera, sin que sea necesario, por tanto, aplicar el procedimiento del artículo 235 (Artículo $308 \mathrm{CE}$ ) ni basarse en los poderes conferidos a la Comunidad por los artículos 111(Derogado) y 113 (Artículo $133 \mathrm{CE}$ ) en materia de política comercial común. Efectivamente, no estimo que la presencia del artículo 235 del Tratado excluya la aplicabilidad del método de interpretación denominado "doctrina de los poderes implícitos", en la medida en que el reconocimiento de los poderes de acción a la Comunidad sea necesario no ya de modo general, como prevé esta norma, para la prosecución de los objetivos del Tratado, sino más precisamente para el correcto ejercicio de las competencias expresamente conferidas a la Comunidad en sectores 
miembros en la materia, los cuales deben eliminar de sus legislaciones todas aquellas disposiciones que puedan acarrear una disparidad que afecte el intercambio comercial con terceros países ${ }^{42}$.

específicos». EI TJCE no realizo en su sentencia (12 de julio de 1973 RC. 1973, tomo I, Págs. 897 a 911) un pronunciamiento especifico al respecto, más sin embargo reconoce que «el funcionamiento efectivo de la Unión aduanera justifica una interpretación amplia de los artículos 9 (Artículo 23 CE), 27 (Derogado), 28 (Artículo 26 CE), 111 (Derogado) y 113 (Artículo $133 \mathrm{CE}$ ) del Tratado y de las facultades que estas disposiciones confieren a las instituciones, con el fin de permitirles regular de manera coherente, con medidas tanto autónomas como convencionales, los intercambios económicos externos». En el mismo sentido de las conclusiones encontramos a LYONS, T. EC customslaw. $1^{\circ} \mathrm{Ed}$. New York: Oxford University Press, 2005.Pág. 99 «Artícle 26 which provides, as we saw in Chapter 1, that the common duties of the customs union are to be fixed by the Council acting by a quialified majority on a proposal from the Comission. It noted that, in these circumstances, the council could confer on the comissión powers for the implementation of the rules which it lays down".

42 STJCE de 13 de diciembre de 1973, asuntos acumulados 37 y 38/73, caso FONDO DE DIAMANTISTAS. RC. 1973, tomo II Pág.1624, Párrafos 22 y 23 "A partir del establecimiento del Arancel Aduanero Común, los Estados miembros no pueden establecer unilateralmente nuevas exacciones sobre las importaciones directamente procedentes de países terceros ni aumentar el nivel de las existentes en esa fecha; que en lo que se refiere a las exacciones existentes, la aplicación de la política comercial común debe llevar consigo la supresión de todas las disparidades fiscales y comerciales nacionales que afecten a los intercambios con países terceros;"; o explicado de manera aun más grafica encontramos a LINDE PANIAGUA, $E$. "Sistema de distribución de competencias y racionalización del sistema normativo" en Revista de derecho de la Unión Europea, №. 3, 2o Semestre de 2002. Pág. 264. «la Comunidad tiene atribuida la competencia exclusiva para la determinación del Arancel Aduanero Común, que excluye el establecimiento por los Estados miembros de aranceles nacionales. Resulta obvio que nada impedía que se hubiera establecido de modo expreso un texto como el que sigue: "La Comunidad tiene atribuida la competencia exclusiva para el establecimiento del Arancel Aduanero Común. Los Estados miembros no podrán dictar norma alguna en la materia, salvo que la Comunidad lo autorice expresamente. El Consejo, por mayoría cualificada y a propuesta de la comisión, aprobará mediante reglamento el Arancel Aduanero Común». 
Esta prohibición tácita junto a lo dispuesto en el artículo 25 CE (actual artículo 30 TFUE), excluían la participación de los Estados miembros en la regulación del comercio intracomunitario y el intercambio comercial con terceros países, concentrando en la CE la competencia material para normar unilateralmente estos rubros, así como de todas aquellas materias necesarias para regular el correcto funcionamiento de la Unión aduanera comunitaria y garantizar el estricto apego y consecución de los principios postulados en el artículo 27 CE (actual artículo 32 TFUE) ${ }^{43}$, cerrando con ello el círculo de la denominada vertiente interna de la Unión aduanera.

Estos principios, como se puede observar en las múltiples citas que se hacen, siguen vigentes en el actual TFUE bajo otro número o bien dispersos en el texto de nuevos artículos, por lo que no se puede negar que todos y cada uno de ellos sirvieron de base para la adopción del actual texto del TFUE y como fundamento para el reconocimiento expreso en el Tratado de la

\footnotetext{
${ }^{43}$ Artículo $27 \mathrm{CE}$ «En el cumplimiento de las funciones que le son atribuidas en el presente capítulo, la Comisión se guiará por: a) la necesidad de promover los intercambios comerciales entre los Estados miembros y terceros países; b) la evolución de las condiciones de competencia dentro de la Comunidad, en la medida en que dicha evolución tenga por efecto el incremento de la capacidad competitiva de las empresas; c) las necesidades de abastecimiento de la Comunidad en materias primas y productos semielaborados, procurando que no se falseen, entre los Estados miembros, las condiciones de competencia de los productos acabados; d) la necesidad de evitar perturbaciones graves en la vida económica de los Estados miembros y garantizar un desarrollo racional de la producción y una expansión del consumo en la Comunidad".
} 
competencia exclusiva de la UE para legislar en el ámbito de la Unión aduanera $^{44}$.

No obstante lo anterior, el Arancel Aduanero Común no sólo es fruto de las potestades autónomas de la Comunidad, sino que también es consecuencia de acuerdos internacionales suscritos por la Comunidad con terceros países y/o organismos internacionales, facultad que posee la Comunidad en el ámbito material de la "Política comercial común".

El antiguo artículo 133 CE (actual artículo 207 TFUE), establece la base de la Política Comercial Común fundándola en: «principios uniformes, particularmente por lo que se refiere a las modificaciones arancelarias, la celebración de acuerdos arancelarios y comerciales, la consecución de la uniformidad de las medidas de liberalización, la política de exportación, así como las medidas de protección comercial, y, entre ellas, las que deban adoptarse en caso de dumping y subvenciones ${ }^{45}$. Concede con ello una serie de competencias $^{46}$ que inciden directamente en la materia aduanera y más

\footnotetext{
${ }^{44}$ TFUE artículo 3.1 fracción a)
}

${ }^{45}$ El Tratado de Ámsterdam añade un nuevo apartado al artículo $133 \mathrm{CE}$, el cual « prevé que el Consejo, previa consulta al Parlamento Europeo, pueda extender el ámbito del artículo 133 a las negociaciones y acuerdos internacionales relativos a los servicios y a los derechos de la propiedad intelectual en la medida en que ya no están incluidos en el ámbito de la política comercial común». http://europa.eu/scadplus/leg/es/lvb/a20000.htm

\footnotetext{
${ }^{46}$ Las competencias atribuidas en el marco de la política comercial común son de competencia exclusiva de la Comunidad. Ver al respecto: Dictamen 1/75. STJCE de 15 de diciembre de 1976, asunto 41/76, caso Donckerwolke. RC 1976, Pág. 667 aparto 32. «Que la competencia en materia de política comercial ha sido transferida en su conjunto a la Comunidad, de acuerdo con el artículo 113 (Artículo 133 CE), apartado 1, por lo que las medidas de política comercial
} 
específicamente sobre el Arancel Aduanero Común, dando origen a la denominada "vertiente exterior" ${ }^{37}$ de la Unión aduanera, la cual se encarga de

de carácter nacional no son admisibles a partir del final del período de transición más que en caso de una habilitación específica por parte de la Comunidad". STJCE de fecha 18 de febrero de 1986, asunto 174/84, apartados 30 y 31. "furthermore , as the court stated in its opinion of 11 november 1975 (opinion 1/75 , (1975 ecr 1355 ), ' it cannot be accepted that in a field covered by export policy and more generally by the common commercial policy the member states should exercise a power concurrent to that of the community, in the community sphere and in the international sphere . . . to accept that the contrary were true would amount to recognizing that, in relations with third countries, member states may adopt positions which differ from those which the community intends to adopt, and would thereby distort the institutional framework, call into question the mutual trust within the community and prevent the latter from fulfilling its task in the defence of the common interest. It must therefore be concluded, as the court held in its judgment of 15 december 1976 (case 41/76, donckerwolke $v$ procureur de la republique, (1976) ecr 1921 ), that since full responsibility in the matter of commercial policy was transferred to the community by article 113(1) measures of commercial policy of a national character are only permissible after the end of the transitional period by virtue of specific authorization by the community» .

${ }^{47}$ INAMA, S. y VERMULST, E. Customs and Trade Laws of the European Community.Londres: The Hague, 1999, Pág. 6 "Two important aspects of the customs union must be emphasized: the external an internal dimensions. The external dimension relates to the treatment reserved for products from third countries which is determined by the existence of a Common Comercial Policy and its related trade and customs laws. The internal dimension is inherent in the free circulation of gooods originating in the EC Member States and the free circulation whitin the customs union of the third country products put into free circulation». LASOK, D. The Trade and Custmos Law of the Europan Union.3 Ed. London: Kluwer Law, 1997, Pág. 363. "The Common Commercial policy (CCP) is, next to the CCT (Common Customs Tariff), the twin regulator of the Community external trade. The CCP (EC Articles 110-115) is connected with the Community Economic Policy. Whilst the CCT forms the external customs barrier the function of the CCP is to integrate the Member States'trade with third countries into a Community system and to protect the interests of the Community as a whole. As a result the Community should enter the world market as a single trading unit». LYONS, T. EC customs law. Oxford: Oxford University press, 2001, Pág. 40 «The existence of such a common commercial policy is clearly essential for the operation of a customs union and indeed the customs union is essential for a common commercial policy. The policy is implemented by Community legislation, such as that governing imports and exports (often referred to as "autonomus"comercial policy") but also 
regular las relaciones comerciales de la Unión con terceros países ${ }^{48}$ y/o organismos internacionales ${ }^{49}$ a través de la firma de acuerdos arancelarios o comerciales. Estas atribuciones se insertan, de igual manera, en el texto del TFUE y se reconoce la exclusividad de la Unión sobre ellas ${ }^{50}$.

En torno a la potestad para la modificación del Arancel Aduanero Común a que hace referencia el artículo 207 TFUE, la reforma efectuada por el Tratado

by agreements with third countries on trade matters (often referred to as "conventional" commercial policy). This leaves little room for action by the autorities of the Member States». TORRENT, R. "El futuro de la Unión Europea visto desde sus entrañas, la Unión aduanera", en Revista española de Derecho Europeo, № 4, Octubre -Diciembre 2002, Pág. 615 «La política comercial tiene dos vertientes, una interna y otra externa. En la primera debe de producirse toda la legislación necesaria para definir el régimen aplicable en el territorio aduanero al comercio internacional con países terceros; en la segunda, deben negociarse y celebrarse todos los acuerdos internacionales referidos a dicho régimen. La existencia de esta segunda vertiente viene impuesta (afortunadamente) por una realidad internacional que limita el unílateralismo en materia comercial. (...) el artículo 133, "ex»113, TCE, contempla sobre todo, pero no exclusivamente, la vertiente externa mientras que el artículo 26 , “ex» 28 , contempla la pieza esencial de la vertiente interna (la determinación del arancel)».

${ }^{48}$ Ver al respecto Dictamen del TJCE caso: 1/75 de 11 de noviembre de 1975, REC. 1975 Pág. 386. "Al adoptar las medidas necesarias para la aplicación de los principios contenidos en las anteriores disposiciones, principalmente los previstos en el artículo 113 del Tratado, relativos a la política comercial común, la Comunidad está facultada, en virtud de sus competencias, no sólo para adoptar normas internas de Derecho comunitario, sino también para celebrar acuerdos con países terceros de conformidad con el apartado 2 del artículo 113 y con el artículo 114 del Tratado».

49 Dictamen del TJCE caso: 1/94 de 15 de noviembre de 1994, Rec. 1994 "XXXIV. De las consideraciones precedentes se deduce que sólo la Comunidad es competente, conforme a lo dispuesto en el artículo 113 del Tratado CE, para celebrar los Acuerdos Multilaterales sobre el Comercio de Mercancías».

${ }^{50}$ TFUE Artículo 3.1 inciso e) 
de Ámsterdam a la Sección segunda del Capitulo Unión aduanera ${ }^{51}$, plantea un problema doctrinal bastante ilustrativo para dilucidar la adecuada determinación de la base jurídica para las modificaciones arancelarias, que es igualmente válido para el resto de las normas aduaneras comunitarias.

Así, el artículo 28 del Tratado CE (anterior al tratado de Ámsterdam) ${ }^{52}$ establecía la competencia exclusiva del Consejo para fijar, modificar o suspender autónomamente los derechos del Arancel Aduanero Común; sin embargo tras el Tratado de Ámsterdam el texto del artículo cambia por completo y el artículo 26 CE (actual artículo 31 TFUE) alude únicamente a la potestad exclusiva del Consejo para fijar los derechos arancelarios, omitiendo lo concerniente a la modificación y suspensión del Arancel Aduanero Común. Esto plantea una disyuntiva: las capacidades para la modificación y suspensión autónoma de los derechos del Arancel Aduanero Común, bien se consideran implícitas en la capacidad de fijar los derechos del Arancel Aduanero Común o bien se disocian de la capacidad de fijar los derechos del Arancel Aduanero

\footnotetext{
${ }^{51}$ El Tratado de Ámsterdam modifica la antigua Sección segunda de la Unión aduanera relativa al establecimiento del ARANCEL ADUANERO COMÚN derogando la mayoría de sus artículos que en gran medida eran de carácter transitorio y una vez entrado en vigor el ARANCEL ADUANERO COMÚN carecían de sentido, por lo cual se concentró la esencia de esta sección en el texto del artículo 26 CE.

${ }^{52}$ Artículo 28 del Tratado CE. «El Consejo decidirá por mayoría cualificada y a propuesta de la Comisión toda modificación o suspensión autónoma de los derechos del Arancel Aduanero Común».
} 
Común y se trasladan a la política comercial común, que ya gozaba de poderes para modificar los derechos del Arancel Aduanero Común vía convencional ${ }^{53}$.

Cabe destacar que en ambos supuestos la competencia exclusiva ${ }^{54}$ para modificarlos de manera autónoma o convencional recae sobre el Consejo como hasta antes del Tratado de Ámsterdam, por lo cual su naturaleza y tramitación no varían ${ }^{55}$. La variante e importancia del caso radica en la adecuada elección

${ }^{53}$ Postura que sostiene GONZÁLEZ ALONSO, L.N. "Política comercial común" en Derecho comunitario material. Madrid: Mac Graw Hill, 2000. Pág. 429 que comenta lo siguiente al referirse al Art. $26 \mathrm{CE}$ «En su versión anterior al Tratado de Ámsterdam, esta disposición también aludía a la posibilidad de que el Consejo decidiese suspender unilateralmente la aplicación de los derechos del ARANCEL ADUANERO COMÚN, para facilitar, por ejemplo, el aprovisionamiento de determinadas industrias comunitarias durante un periodo de tiempo en concreto. Con buen criterio se ha suprimido aquella referencia, que no hacía mas que complicar la determinación del fundamento jurídico de este tipo de actos, puesto que el artículo 133 CE menciona genéricamente las modificaciones arancelarias entre los instrumentos de la PCC».

${ }^{54}$ STJCE de 13 de diciembre de 1973, asuntos acumulados 37 y 38/73, Ob.cit... Apartado 24 Pág.1625 «la reducción o la supresión de las exacciones que gravan las importaciones directamente procedentes de países terceros son competencia de las instituciones de la Comunidad». STJCE de 27 de septiembre de 1988, caso: Comisión vs Consejo, asunto 165/87, REC. 1988, apartado 9. "Se deduce de esta comprobación que el Consejo dispone en materia arancelaria de una competencia general que, como tal, se apoya tanto en el artículo 28 como en el artículo 113 del Tratado, en la medida en que es independiente de si la modificación de los derechos del ARANCEL ADUANERO COMÚN se realiza de manera autónoma (artículo 28) o en el marco de acuerdos arancelarios u otras medidas de política comercial común (artículo 113)».

${ }^{55}$ STJCE de 27 de septiembre de 1988, caso: Comisión vs Consejo, asunto 165/87 Ob. Cit... apartado 12 «el Acta Única Europea ha equiparado los requisitos de procedimiento del artículo 28 a los del artículo 113 del Tratado». 
de la base jurídica ${ }^{56}$ para la realización de modificaciones o suspensiones a los derechos del arancel aduanero común, pues en caso contrario implicaría la nulidad del acto adoptado ${ }^{57}$.

56 Respecto del tema la opinión del Parlamento Europeo PE 364.661v01-00, Asunto: "Fundamento jurídico de la propuesta de Directiva del Consejo relativa a medidas comunitarias de lucha contra la influenza aviar (COM(2005)0171 -C6 0195/2005 - 2005/0062(CNS))", nos brinda una perspectiva clara de la relevancia de la fundamentación en el sistema legislativo comunitario al decir: "Debe tenerse en cuenta que todos los actos comunitarios deben basarse en un fundamento jurídico establecido en el Tratado (o en otro acto jurídico que deban aplicar). El fundamento jurídico define las competencias de la Comunidad ratione materiae y especifica de qué forma deben ejercerse dichas competencias, en particular, los instrumentos legislativos que pueden utilizarse y el procedimiento de toma de decisión". Para la elección del fundamento jurídico adecuado se deberán tomar a cuenta las siguientes consideraciones: "Según jurisprudencia reiterada, la elección de la base jurídica de un acto comunitario debe fundarse en elementos objetivos susceptibles de control jurisdiccional, entre los que figuran, en especial, la finalidad y el contenido del acto (véanse, en particular, las sentencias Dióxido de titanio, antes citada, apartado 10; de 4 de abril de 2000, Comisión/Consejo, C-269/97, Rec. p. I2257, apartado 43, y de 11 de septiembre de 2003, Comisión/Consejo, C-211/01, Rec. p. I0000, apartado 38).

Si el examen de un acto comunitario muestra que éste persigue un doble objetivo o que tiene un componente doble, y si uno de ellos puede calificarse de principal o preponderante, mientras que el otro sólo es accesorio, dicho acto debe fundarse en una sola base jurídica, a saber, aquella que exige el objetivo o componente principal o preponderante (véanse, en este sentido, las sentencias de 17 de marzo de 1993, Comisión/Consejo, C-155/91, Rec. p. I-939, apartados 19 y 21; de 30 de enero de 2001, España/Consejo, C-36/98, Rec. p. I-779, apartado 59, y de 11 de septiembre de 2003, Comisión/Consejo, antes citada, apartado 39).

Excepcionalmente, si resulta probado que el acto persigue al mismo tiempo distintos objetivos que están inseparablemente unidos, sin que pueda considerarse que uno es secundario y complementario con respecto al otro, dicho acto deberá adoptarse sobre las distintas bases jurídicas pertinentes (véanse, en particular, las sentencias de 19 de septiembre de 2002, Huber, C-336/00, Rec. p. I-7699, apartado 31; de 12 de diciembre de 2002, Comisión/Consejo, C-281/01, Rec. p. I-12049, apartado 35, y de 11 de septiembre de 2003, Comisión/Consejo, antes citada, apartado 40, así como el dictamen 2/00, de 6 de diciembre de 2001, Rec. p. I9713, apartado 23). 
La respuesta al planteamiento nos la otorga la propia estructura tarifaria del Arancel Aduanero Común la cual, como es conocido, alberga en la columna tercera los derechos autónomos ${ }^{58}$ y la otra los derechos convencionales. Los primeros corresponden a los derechos que se aplican normalmente a la importación de terceros países con los cuales la CE no tiene firmados acuerdos preferenciales $^{59}$, por lo cual su establecimiento y modificación son efectuados

Sin embargo, la acumulación de dos bases jurídicas queda excluida cuando los procedimientos previstos para una y otra base jurídica son incompatibles (véanse, en especial, la sentencia Dióxido de titanio, antes citada, apartados 17 a 21, y de 25 de febrero de 1999, Parlamento/Consejo, asuntos acumulados C-164/97 y C-165/97, Rec. p. I-1139, apartado 14)». Fuente: STJCE de fecha 29 de abril de 2004, asunto C-338/01, apartados 54 a 57.

${ }^{57}$ Verbigracia la célebre sentencia de fecha 26 de marzo de 1987, caso: Comisión vs Consejo, asunto 45/86, REC. 1987.

58 Aun cuando el título de la columna sea el de Derecho Convencional, los derechos autónomos están consignados a pie de página. Ver al respecto Reglamento 948/2009, Disposiciones preliminares, Título I, las disposiciones preliminares del, en específico Título I, apartado B .1.

${ }^{59}$ CAÑAS CARBALLIDO, M.: "La gestión del arancel aduanero comunitario y de la economía arancelaría en el marco de la Unión aduanera de la CEE". En: La aduana ante las Comunidades Europeas. 1ํㅡ. Ed. Madrid, Ministerio de Hacienda, Instituto de Estudios Fiscales, 1984. Pág. 246 «Son los que gravan las mercancías clasificadas en las partidas o subpartidas arancelarias en que no existen derechos convencionales o en que, existiendo éstos son mayores que los autónomos». CABELLO PERÉZ, M. Las aduanas y el comercio internacional, 1ํㅡ. Madrid, ESIC, 2000. Pág. 106 «AUTÓNOMOS: Son los derechos normales; los que se aplican a la importación de mercancías de países terceros sin acuerdos o preferencias que supongan rebajas o reducciones de los tipos arancelarios». PELECHA ZOZAYA, F. El Código Aduanero Comunitario y su aplicación en España.1ª Ed. Madrid: Marcial Pons, 1995, Pág. 84 «Entendemos por operaciones no preferenciales (también llamadas operaciones de Derecho común) aquellas que se dan en el comercio entre la CE y otros países con los que aquélla no ha suscrito ningún acuerdo o convenio de carácter preferencial por lo que a los derechos de aduana respecta, y a los que, por lo demás, tampoco otorga unilateralmente un trato preferencial. También son operaciones no preferenciales las que se dan entre la CE y países con los que aquélla sí tiene suscrito un acuerdo o convenio preferencial, o a los que otorga 
de motu propio por la Comisión en base a las potestades concedidas por el artículo 31 TFUE $^{60}$. Por su parte los derechos convencionales, como su nombre indica, son aquellos aranceles nacidos de tratados internacionales y que se aplican a las mercancías originarias de los países contratantes del Acuerdo General sobre Aranceles Aduaneros ${ }^{61}$ o con los que la CE tiene acuerdos comerciales en los que incluya la cláusula de nación más favorecida

unilateralmente un régimen preferencial, pero en relación con productos que no están cubiertos por esos regímenes preferenciales (ya sean concedidos unilateralmente por la CE ya sean por fruto de un acuerdo o convenio preferencial firmado por ésta con uno o varios países terceros)».

60 Un ejemplo modificación autónoma del Arancel Aduanero Común fundamentada en el artículo 26 CE seria el "Reglamento (CE) n 493/2005 del Consejo, de 16 de marzo de 2005, por el que se modifica el anexo I del Reglamento (CEE) $n^{\circ} 2658 / 87$ relativo a la nomenclatura arancelaria y estadística y al Arancel Aduanero Común". DO L 82 de 31.3.2005, p. 1-2. En tanto lo que respecta a la suspensión autónoma del ARANCEL ADUANERO COMÚN ver la: "Comunicación de la Comisión relativa a las suspensiones y contingentes arancelarios autónomos" Diario Oficial $n^{\circ} \mathrm{C} 128$ de 25/04/1998 p. $0002-0005$.

${ }^{61}$ Mejor conocido por sus siglas en Inglés GATT 
en materia arancelaria ${ }^{62}$, por lo cual su instauración y modificación se hace con base en las potestades otorgadas por el artículo 207 TFUE $^{63}$.

Si las modificaciones o suspensiones del Arancel Aduanero Común se efectúan de manera general, dichos actos deben de ser adoptados con base en ambos artículos ${ }^{64}$, lo cual es una consecuencia lógica de integración de las

${ }^{62}$ CABELLO PERÉZ, M. Las aduanas y el comercio internacional,... Ob. Cit. "Convencionales son los derechos (tipos) más bajos, que se aplican en función de reducciones derivadas de la aplicación de acuerdos arancelarios preferenciales». CLAVIJO HERNÁNDEZ, F. Curso de Derecho Tributario parte especial. Madrid: Marcial Pons, 2002. Pág. 777 «Los derechos convencionales son los aplicables a las mercancías originarias de países que son partes contratantes del Acuerdo General sobre Aranceles Aduaneros y Comercio o de países con los que la Comunidad tiene suscritos acuerdos que tienen la cláusula de nación más favorecida en materia arancelaria, y, salvo disposiciones en contrario, también son aplicables a las mercancías distintas de las mencionadas, importadas de terceros países. Los derechos autónomos se aplican cuando sean inferiores a los derechos convencionales».

${ }^{63}$ Ejemplo de modificaciones basadas en el artículo 133 CE ver el : "REGLAMENTO (CE) No 838/2006 DEL CONSEJO de 20 de marzo de 2006 sobre la aplicación del Acuerdo en forma de Canje de Notas entre la Comunidad Europea y la República Popular China en virtud del artículo XXIV, apartado 6, y del artículo XXVIII del Acuerdo General sobre Aranceles Aduaneros y Comercio (GATT) de 1994 sobre la modificación de concesiones en las listas de la República Checa, la República de Estonia, la República de Chipre, la República de Letonia, la República de Lituania, la República de Hungría, la República de Malta, la República de Polonia, la República de Eslovenia y la República Eslovaca en el marco de su adhesión a la Unión Europea, por el que se modifica y completa el anexo I del Reglamento (CEE) no 2658/87 relativo a la nomenclatura arancelaria y estadística y al Arancel Aduanero Común", DO L 154 de 8.6.2006, p. 1/4. En tanto un ejemplo relativo a las suspensiones convencionales basadas en el artículo 133 CE sería el: "Reglamento (CE) No 215/2000 Del Consejo de 24 de enero de 2000 que prorroga para el 2000 las medidas previstas en el Reglamento (CE) no 1416/95 por el que se establecen determinadas concesiones en forma de contingentes arancelarios comunitarios para 1995 de determinados productos agrícolas transformados". DO L 24 de 29.1.2000, p. 9/11.

${ }^{64}$ Ver la ya citada STJCE de 27 de septiembre de 1988, caso: Comisión vs Consejo, asunto $165 / 87$,considerando 11 , que dice «Conviene añadir que en la medida en que la competencia 
vertientes interna y externa de la UE, en las que repercute la aplicación del Arancel Aduanero Común. Son por lo tanto ambas políticas la base jurídica idónea bajo las cuales se han adoptado y deberán de adoptar en lo subsecuente la mayoría de actos que regulan el comercio exterior de la Comunidad y a las que habría que sumarles en la actualidad el ya multicitado artículo 3 que concede en sus fracciones a) y e) facultades exclusivas a la UE para legislar en los ámbitos de Unión aduanera y Política Comercial Común.

de una institución se apoya en dos disposiciones del Tratado, ésta debe adoptar los actos correspondientes basándose en ambas disposiciones». Un ejemplo claro de la aplicación de los artículos 26 y 133 CE como fundamento para la modificación del ARANCEL ADUANERO COMÚN, es el "Reglamento (ce) n²54/2000 del Consejo de 31 de enero de 2000 por el que se modifica el Reglamento (CEE) $n^{\circ} 2658 / 87$ relativo a la nomenclatura arancelaria $y$ estadística del Arancel Aduanero Común"». 


\subsection{El Derecho aduanero derivado.}

Como su propio nombre indica el Derecho aduanero derivado o normativa aduanera comunitaria ${ }^{65}$, nace de la aplicación y/o ejercicio de los principios y competencias de que es dotada la Comunidad en los Tratados Constitutivos para establecer, modificar o suspender el Arancel Aduanero Común, regular las potestades derivadas de estas atribuciones, y adoptar las medidas de política comercial necesarias para garantizar el correcto funcionamiento de la Unión aduanera ${ }^{66}$. No obstante, para Márquez y Márquez, «el Derecho aduanero europeo es y está constituido por el conjunto de normas

\footnotetext{
${ }^{65}$ Estimo necesario realizar una puntualización respecto a este término siguiendo al Ex - Jefe de División de la Dirección General del Mercado Interior y de los Asuntos Industriales de la Comisión de las Comunidades Europeas MATTERA, A. El mercado único europeo sus reglas, su funcionamiento. 1 ${ }^{\text {a }}$ Ed. Madrid: Civitas, 1991. Pág. 537 para quien la expresión normativa aduanera comunitaria «no comprende más que el Derecho derivado, a diferencia de la expresión «Derecho aduanero común» que engloba, además, el Derecho primario es decir los Tratados constitutivos».

${ }^{66}$ Conclusiones del Abogado General Sr. Alberto Trabucchi, presentadas el 27 de junio de 1973, asunto 8/73, Ob. Cit... Pág. 913 "Las mencionadas limitaciones a la aplicabilidad del artículo 235 (Artículo $308 \mathrm{CE}$ ) en materia aduanera resultan del reconocimiento del hecho de que la Comunidad ya dispone en esta materia de una potestad reglamentaria general en virtud tanto del artículo 9 (Artículo $23 \mathrm{CE}$ ), que establece que la Comunidad se basará en una Unión aduanera, como de los artículos 111 (Derogado) y 113 (Artículo133 CE), que atribuyen expresamente a la Comunidad poderes de acción para ejecutar una política comercial exterior propia. Si, basándose en la Unión aduanera, el legislador estimo pertinente reconocer a la Comunidad una potestad reglamentaria general en materia de política comercial exterior, con mayor razón debe la Comunidad disponer de dicho poder para asegurar el correcto funcionamiento del Arancel Aduanero Común. Esta tesis se confirma en las disposiciones del apartado 3 del artículo 23 (derogado) y 28 (Artículo 26 CE) del Tratado, que presuponen una regulación obligatoria y unitaria de la materia arancelaria».
} 
y disposiciones legales de distinto rango, contenido y fines que regulan el comercio exterior $" 67$.

No existe una definición uniforme en torno al concepto de "normativa aduanera" pues el derecho positivo comunitario en distintas disposiciones enumera de manera más o menos amplia los conceptos y normas que la integran. Verbigracia, el aún vigente Código Aduanero ${ }^{68}$ dispone en su artículo $1^{\circ}$ que la normativa aduanera está constituida por el propio Código junto con las normas de desarrollo adoptadas tanto en el ámbito comunitario como en el nacional. No obstante el "Convenio relativo a la asistencia mutua y la cooperación entre las administraciones aduaneras" es más amplio en su definición y considera como normativa aduanera los subconjuntos normativos, a saber:

«- el conjunto de disposiciones comunitarias y de disposiciones adoptadas para la aplicación de la normativa comunitaria que regulan la importación, exportación, tránsito y permanencia de mercancías que sean objeto de intercambios entre los Estados miembros y países terceros, así como entre los Estados miembros en lo que respecta a las mercancías que no tengan estatuto comunitario con arreglo al apartado 2 del artículo 9 del Tratado constitutivo de

\footnotetext{
${ }^{67}$ Márquez y Márquez, A. "El Derecho aduanero español: su aproximación e integración en el Derecho aduanero europeo" en la Revista española de Derecho Financiero. Número 10 de abril/junio 1976, Civitas, Madrid. Pág. 283

68 Pues aun cuando el Código Aduanero Modernizado sustituirá al Código aduanero Comunitario de 1992, cuando las disposiciones de aplicación necesarias sean adoptadas y aplicables, a más tardar el 24 de junio de 2013. Hasta entonces, el código actual continuará aplicándose. Por lo que es necesario su estudio conjunto.
} 
la Comunidad Europea o a las mercancías sujetas a controles o investigaciones complementarios para la determinación de su estatuto comunitario,

- el conjunto de disposiciones adoptadas a nivel comunitario en el marco de la política agrícola común y de las normativas específicas adoptadas respecto a mercancías resultantes de la transformación de productos agrícolas,

- el conjunto de disposiciones adoptadas a nivel comunitario para los impuestos especiales armonizados y para el impuesto sobre el valor añadido sobre la importación, junto con las disposiciones nacionales que los aplican»; ${ }^{69}$

Por su parte, el Código aduanero modernizado define la normativa aduanera de manera muy similar al Código aduanero conceptuándola como un cuerpo legal integrado por el Código aduanero, sus disposiciones de aplicación tanto comunitarias como nacionales y agrega tres párrafos por demás representativos, incluyendo dentro de este cuerpo legal como es obvio al Arancel Aduanero Común, la legislación relativa a franquicias, además de los acuerdos internacionales que afecten a la materia aduanera ${ }^{70}$. Dada su

\footnotetext{
${ }^{69}$ Definición obtenida del artículo 4.2 del Acto del Consejo de 18 de diciembre de 1997 por el que se celebra, sobre la base del artículo K.3 del Tratado de la Unión Europea, el Convenio relativo a la asistencia mutua y la cooperación entre las administraciones aduaneras (98/C 24/01).

${ }^{70}$ Reglamento (CE) № 450/2008 del Parlamento Europeo y del Consejo de 23 de abril de 2008. En adelante será citado bajo las iníciales CAM. "Artículo 4. Definiciones. En el marco del presente Código, se entenderá por: ...2) «normativa aduanera»: el cuerpo legal integrado por:

a) el código y las disposiciones de aplicación de este que se adopten a nivel comunitario y, en su caso, nacional;
} 
vigencia y mayor concreción, nos parece la definición más correcta por lo que en este epígrafe analizaremos brevemente las normas referidas, es decir, el Reglamento (CEE) № 2658/87 del Consejo de 31 de diciembre de 1987, relativo a la nomenclatura arancelaria y estadística y al Arancel Aduanero Común, y el Reglamento (CE) № 450/2008 del Parlamento Europeo y del Consejo de 23 de abril de 2008 por el que se establece el código aduanero comunitario (código aduanero modernizado) ${ }^{71}$.

\subsubsection{El Reglamento (CEE) no $2658 / 87$ del Consejo de 31 de diciembre de 1987, relativo a la nomenclatura arancelaria y estadística y al Arancel Aduanero Común.}

Como advertíamos en el epígrafe relativo al establecimiento del Arancel Aduanero Común ${ }^{72}$ este Reglamento, adoptado el 31 de diciembre de 1987, deroga el Reglamento 950/68 del Consejo de 28 de junio de 1968, adoptando una norma mucho más ambiciosa que la norma derogada, pues como se desprende de su propio título, no solo cumple con el establecimiento del

b) el arancel aduanero comunitario;

c) la legislación relativa al establecimiento de un régimen comunitario de franquicias aduaneras;

d) los acuerdos internacionales que contengan disposiciones aduaneras aplicables en la Comunidad».

${ }^{71}$ En relación con el aún vigente reglamento CEE 2913/92 Del Consejo de 12 de Octubre de 1992, que establece el Código Aduanero Comunitario (CA).

${ }^{72}$ Ver "El establecimiento del Arancel Aduanero Común y la Política Comercial Común", Punto 1.3, Pág. 
arancel aduanero sino que además cumple funciones de estadística, nomenclatura y apoyo a otras políticas, que se refleja en la instauración de la nomenclatura combinada y el arancel integrado de las comunidades europeas $^{73}$

\subsubsection{Fundamentación}

En cuanto a su fundamentación, el Reglamento $2658 / 87$ se funda en los artículos 28 (artículo 26 CE, 31 TFUE), 43 (artículo 37 CE, 43 TFUE) y 113 (artículo 133 CE, 207 TFUE) del Tratado C.E.E, es decir, en la Unión aduanera, la política agrícola común y en la política comercial común respectivamente. El sustento en la Unión aduanera y política comercial común, obedece a las razones ya expuestas en el epígrafe en el cual tratamos los aspectos relativos al establecimiento del Arancel Aduanero Común y la Política Comercial Común, resultando innecesario el desarrollarlas en este párrafo, por lo que nos remitimos a lo expuesto en el citado epígrafe ${ }^{74}$.

La inclusión del artículo 43 del Tratado CE como fundamento, obedece a la finalidad protectora que reviste el Arancel Aduanero Común, de cuya estructura y finalidad se sirve la Política Agrícola Común (PAC), a fin de lograr parte de los objetivos que le son encomendados por los Tratados: estabilización de los mercados, garantizar la seguridad de los abastecimientos, asegurar al

\footnotetext{
73 Comúnmente conocido como TARIC por sus siglas en francés "Tarif Integré des Communautés européennes"

${ }^{74}$ Ver al respecto epígrafe 1.3. El establecimiento del Arancel Aduanero Común y la Política Comercial Común. P. 15
} 
consumidor suministros a precios razonables, etc. Para la realización de estos objetivos el Arancel Aduanero Común incluye en la cuarta columna una serie de gravámenes, ayudas o restricciones a la importación y/o exportación de determinados productos agropecuarios ${ }^{75}$.

\subsubsection{La nomenclatura combinada.}

El referido Código Aduanero Modernizado en su artículo 33.2 a) establece como parte integrante del Arancel Aduanero Común la nomenclatura combinada, la cual se establece bajo la base del "sistema armonizado de designación y codificación de mercancías"76, según lo pone de manifiesto el considerando tercero ${ }^{77}$ de la norma en comento. Este hecho resulta bastante interesante, pues en cierta medida hace de este reglamento un acto de adopción especial del "Convenio de 14 de junio de 1983, por el que se adopta el sistema armonizado de Codificación y designación de mercancías”78.

${ }^{75}$ Ver al respecto ÁLVAREZ GÓMEZ PALLETE, J.M. "Aspectos aduaneros de la política agrícola común”. Aduanas. Revista de comercio internacional y estudios fiscales.1985. Págs. 35 a 42

${ }^{76}$ En adelante "SA" de conformidad al sistema de abreviaturas utilizado por la Organización Mundial de Comercio.

${ }^{77}$ Reglamento (CEE) no 2658/87 del Consejo «Considerando que la Comunidad es signataria del Convenio internacional sobre el sistema armonizado de designación y codificación de mercancías, llamado "sistema armonizado", que está destinado a sustituir al Convenio de 15 de diciembre de 1950 sobre la nomenclatura para la clasificación de mercancías en los aranceles aduaneros; que, por consiguiente, dicha nomenclatura combinada deberá establecerse sobre la base del sistema armonizado»

${ }^{78}$ Convenio de Bruselas del Consejo de Cooperación Aduanera (actualmente Organización Mundial de Aduanas) de 14 de junio de 1983, por el que se adopta el "sistema armonizado de 
Hay que tener en cuenta que la propia naturaleza del convenio imposibilita su aplicación directa pues, lejos de establecer una reglamentación amplia y general, prescribe una serie de directrices de carácter formal que deberán tomarse en cuenta e incorporarse en las legislaciones de las partes contratantes relativas a nomenclatura arancelaria y estadística ${ }^{79}$. Por tanto no significa que las partes contratantes contraigan ningún compromiso en lo que se refiere al tipo de los derechos arancelarios ${ }^{80}$, dejando a salvo su poder tributario.

El propio reglamento 2658/87 en su artículo 1.1 hace una exposición de motivos del establecimiento de la nomenclatura combinada arguyendo la

Codificación y designación de mercancías". Aprobado por la CE mediante Decisión del Consejo 369/87 de 7 de abril de 1987. El referido convenio sustituye al Convenio de 15 de diciembre de 1950 sobre la nomenclatura para la clasificación de mercancías en los aranceles aduaneros.

${ }^{79}$ Convenio Internacional sobre el Sistema Armonizado de Designación y Codificación de mercancías, hecho en Bruselas el 14 de junio de 1983, y su protocolo de enmienda, hecho en Bruselas el 24 de junio de 1986. "Artículo 3. "Obligaciones de las Partes contratantes". 1. Sin perjuicio de las excepciones mencionadas en el artículo 4: a) Las Partes contratantes se comprometen, salvo que apliquen las disposiciones del apartado c) siguiente, a que sus nomenclaturas arancelaria y estadística se ajusten al Sistema Armonizado a partir de la fecha de entrada en vigor del presente Convenio para cada Parte. Se comprometen, por tanto, en la elaboración de sus nomenclaturas arancelaria y estadística: 1.ํ $A$ utilizar todas las partidas y subpartidas de Sistema Armonizado sin adición ni modificación, así como los códigos numéricos correspondientes; 2. $\mathrm{A}$ aplicar las Reglas generales para la interpretación del Sistema Armonizado, así como todas las notas de las secciones, capítulos y subpartidas y a no modificar el alcance de las secciones, de los capítulos, partidas o subpartidas del Sistema Armonizado; 3.ำ A seguir el orden de numeración del Sistema Armonizado».

${ }^{80}$ "ART. 9 "Tipos de los derechos de aduanas". Las partes contratantes no contraen, por el presente Convenio, ningún compromiso en lo que se refiere al tipo de los derechos arancelarios». 
necesidad de satisfacer a un tiempo necesidades derivadas del Arancel Aduanero Común, estadística del comercio exterior, así como otras políticas de la comunidad referentes a la importación o exportación de mercancías. ${ }^{81}$

La composición de la nomenclatura combinada, se rige por el artículo 1.2 del reglamento 2658/87, el cual establece que la nomenclatura combinada contendrá:

a) la nomenclatura del sistema armonizado;

b) las subdivisiones comunitarias de dicha nomenclatura, denominadas «subpartidas NC» cuando se especifiquen los tipos de derechos correspondientes;

c) las disposiciones preliminares, las notas complementarias de secciones o de capítulos y las notas a pie de página que se refieran a las «subpartidas NC».

El sistema de codificación de mercancías de la nomenclatura combinada parte de las características, propiedades objetivas y/o fin del producto de que se trate $^{82}$. Los seis primeros dígitos que conforman la nomenclatura combinada

81 Reglamento 2658/87 Art. 1.1 «Se establece por la Comisión una nomenclatura de mercancías, en adelante denominada "nomenclatura combinada» o en forma abreviada «NC», para satisfacer al mismo tiempo las exigencias del Arancel Aduanero Común, de las estadísticas del comercio exterior de la Comunidad y de las otras políticas de la Comunidad relativas a la importación o exportación de mercancías».

82 Ver al respecto. STJCE de 17 de diciembre de 2009, asuntos acumulados C-410/08 a C-412/08, caso Swiss Caps AG. Consideraciones 27 y 29. «27 Debe recordarse que, según reiterada jurisprudencia, en aras de la seguridad jurídica y de la facilidad de los controles, el criterio decisivo para la clasificación arancelaria de mercancías debe buscarse, por regla general, en sus características y propiedades objetivas, tal como están definidas en el 
están sustentados íntegramente en el sistema armonizado, dando cumplimiento con ello a lo dispuesto en el artículo 3.1 a) del Convenio, que establece la aplicación íntegra del sistema armonizado ${ }^{83}$. El Sistema Armonizado utiliza un sistema deductivo, partiendo de una clasificación en 21 secciones $^{84}$ que no se ven reflejadas propiamente en el código numérico, sino que sirven como sistema de agrupamiento de las mercancías por sus

texto de las partidas de la NC y de las notas de secciones o capítulos (véase, en particular, la sentencia de 18 de junio de 2009, Kloosterboer Services, C-173/08, Rec. p. I-0000, apartado 24 y jurisprudencia citada)... 29 Por otra parte, el destino del producto puede constituir un criterio objetivo de calificación, siempre que sea inherente a dicho producto, debiendo poder apreciarse la inherencia en función de las características y de las propiedades objetivas de éste (véase la sentencia de 11 de junio de 2009, Schenker, C-16/08, Rec. p. I-0000, apartado 25)».

${ }^{83}$ Convenio Internacional sobre el SA... Ob. Cit. «Art. 3. 1 a) las partes contratantes se comprometen a: ... 2 $2^{\circ} 2^{\circ}$. A aplicar las Reglas generales para la interpretación del Sistema Armonizado, así como todas las notas de las secciones, capítulos y sub partidas y a no modificar el alcance de las secciones, de los capítulos, partidas o sub partidas del Sistema Armonizado»

${ }^{84}$ Sección I (capítulos 1 a 5, animales vivos y productos del reino animal); Sección II (capítulos 6 a 14, productos del reino vegetal); Sección III (capítulo 15, grasas y aceites animales 0 vegetales); Sección IV (capítulos 16 a 24, productos de las industrias alimentarias, bebidas y líquidos alcohólicos, tabaco); Sección V (capítulos 25 a 27, productos minerales); Sección VI (capítulos 28 a 38, productos de las industrias químicas); Sección VII (capítulos 39 y 40, plástico y caucho); Sección VIII (capítulos 41 a 43, cueros y artículos de viaje); Sección IX (capítulos 44 a 46, madera, carbón vegetal, corcho); Sección X (capítulos 47 a 49, pasta de madera, papel y cartón); Sección XI (capítulos 50 a 63, materias textiles y sus manufacturas); Sección XII (capítulos 64 a 67, calzado, paraguas, flores artificiales); Sección XIII (capítulos 68 a 70, piedra, cemento, productos cerámicos, vidrio); Sección XIV (capítulo 71, perlas finas, metales preciosos); Sección XV (capítulos 72 a 83, metales comunes); Sección XVI (capítulos 84 y 85, máquinas eléctricas); Sección XVII (capítulos 86 a 89, material de transporte); Sección XVIII (capítulos 90 a 92, instrumentos de óptica, aparatos de relojería, instrumentos musicales); Sección XIX (capítulo 93, armas y municiones); Sección XX (capítulos 94 a 96, muebles, juguetes, manufacturas diversas); Sección XXI (capítulo 97, objetos de arte, antigüedades). 
características generales atendiendo al material de su manufactura o género al que pertenece ${ }^{85}$.

Estas 21 secciones agrupan a los 97 capítulos de que consta el Sistema Armonizado, los cuales engloban las actividades económicas más relevantes y/o estado de las mercancías, lo cual se refleja en los dos primeros dígitos de la nomenclatura ${ }^{86}$. Los dos siguientes dígitos corresponden a la partida, es decir, a una identificación particular de la mercancía dentro del género o sector que se integra en el capítulo ${ }^{87}$. El tercer grupo de dígitos corresponde a la subpartida, fija el fin de la importación o características especiales de la mercancía ${ }^{88}$, este tercer grupo constituye también el último que integra el Sistema Armonizado, conformando un total de 1241 partidas y 5210 subpartidas. El séptimo y octavo dígito corresponden a la subdivisión comunitaria denominadas "subpartidas NC", las cuales reflejan de conformidad al artículo 3.1.1 del Código de conducta para la gestión de la nomenclatura combinada ${ }^{89}$ :

\footnotetext{
${ }^{85}$ Ver al respecto: LUX, M. Guide to Community Customs Legislation. 1ํㅡ. Ed. Brussels: Bruylant, 2002. Pág. 79 "The first section of the nomenclature are mainly arranged according to the material the article is made of (e.g. wood) or the species the animal or plant belongs to (e.g. sheep)».

${ }^{86}$ Verbi gratia: Sección I. Animales Vivos y Productos del reino animal. Capitulo 01. Animales vivos

${ }^{87}$ V.gr. 0101 Caballos, asnos, mulos y burdéganos, vivos.

${ }^{88}$ V.gr. 010101 - Reproductores de raza pura

${ }^{89} 2000 / C 150 / 03$
} 
«a) los compromisos internacionales de la Comunidad Europea (por ejemplo, las concesiones arancelarias de la Organización Mundial de Comercio y las recomendaciones de la Organización Mundial de Aduanas);

b) las diversas necesidades de las políticas de la Comunidad Europea, expresadas por los servicios competentes de la Comisión (cuando estas necesidades no queden satisfechas de otra forma);

c) las necesidades legítimas de interés comunitario de determinados sectores, expresadas por los Estados miembros y por las federaciones europeas».

Cuando una partida o subpartida del Sistema Armonizado no se subdivide adicionalmente con fines comunitarios los dígitos séptimo y octavo son "00"90.

Por lo anterior considero conveniente realizar una ejemplificación gráfica de algunos Códigos NC, aun cuando no sea lo habitual en un trabajo de estas

${ }^{90} \mathrm{Si}$ se desea profundizar más en el tema ver al respecto: BONET MARCO, E. "El arancel aduanero de las CEE (Sistema armonizado, nomenclatura combinada y TARIC)". En: Noticias CEE. 1991. № 79 -80. Pag. 27. GARCÍA TRUJILLO, S. "Acuerdo general sobre Aranceles Aduaneros y Comercio (GATT). Exposición crítica y valoración global". Noticias de la Unión Europea. 1994. № 115 - 116. Pág. 63GIFFONI, M. Droit Dounaier de la C.E. Et aspects economiques. $1^{\circ}$ Ed. Luxemburgo: Oficina de publicacionesoficiales de las ComunidadesEuropeas, 1993. Págs. 88 a 94. GOGUEL, F. "Le classement tarifaire des appareils á fonctions multiples". Revue des Affaires Européennes, Law\&EuropeanAffairs. 2005, № 4, Págs. 615 - 620. PHILIPPE, B. "Los escenarios jurídicos de los frentes aduaneros (origen, valor en aduana, nomeclatura, arancel)". Traducido por DE PABLO VARONA, C. Quincena fiscal. № 12, Junio 2006, Pags. 11-13. RENOUE, J.C. "Le tarif douanier commun". Revue française de finances publiques,1983, № 3. Págs. 189 -200. VORK, R. Y KATTENBUSCH, W. "La Gestión Arancelaria En La Comunidad Europea". En: La Modernización de la Gestión Aduanera en los Procesos de Integración Regional. Uruguay: Centro de Formación para la Integración Regional, 1993, pág. 68-75. 
características. El primer ejemplo corresponde a un Caballo de pura raza que se importa a la comunidad con fines reproductivos. El segundo ejemplo es relativo a la importación de un barco cisterna para navegación marítima ${ }^{91}$.

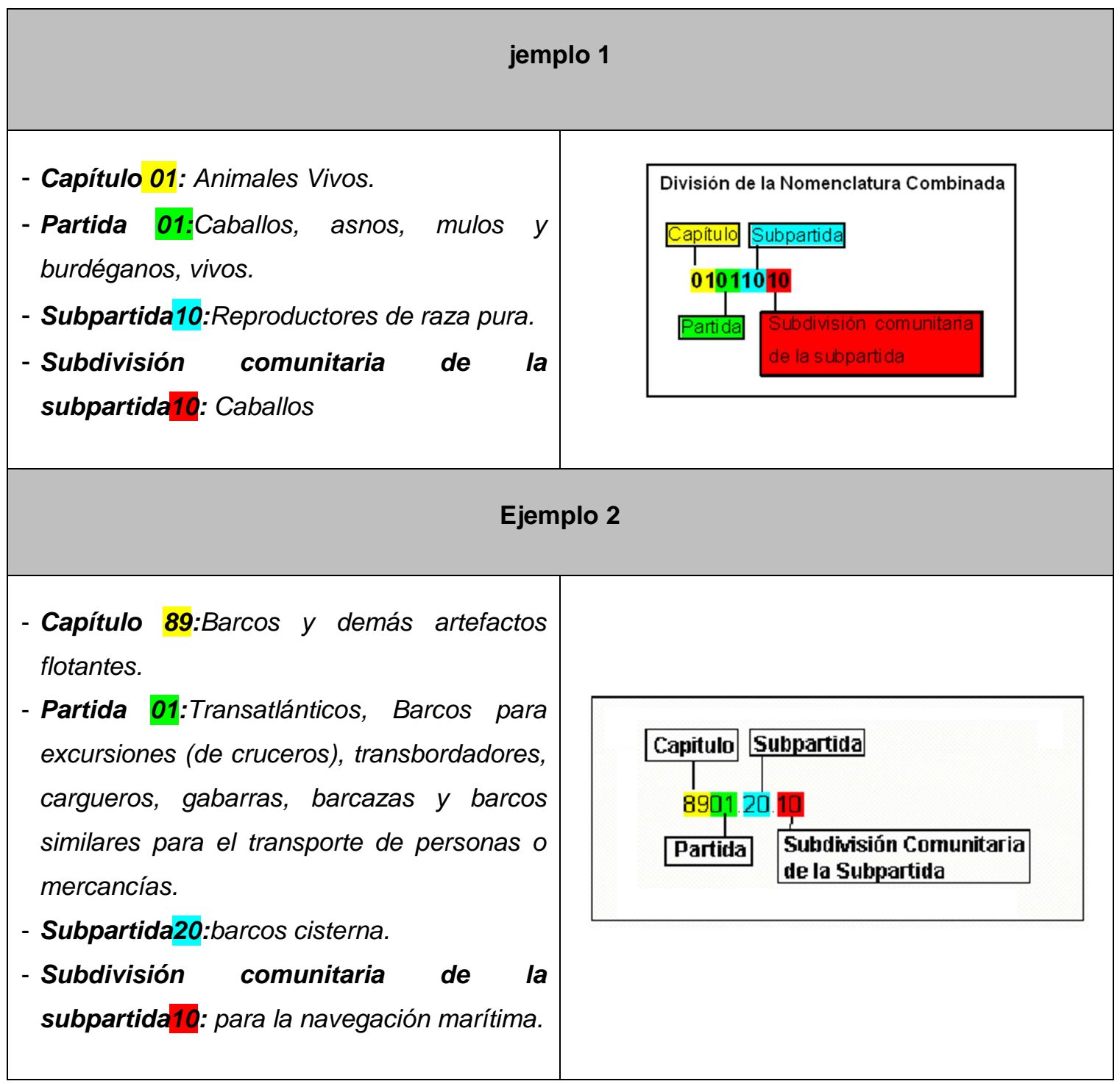

${ }^{91}$ El segundo grafico fue elaborado a partir del ejemplo otorgado por el Prof. CLAVIJO HERNÁNDEZ, F. en Curso de Derecho Tributario, parte especial. Madrid: Marcial Pons, 2002. Pág. 776 


\subsubsection{El Arancel Integrado de las Comunidades Europeas (TARIC)}

El Arancel Integrado de las Comunidades Europeas es establecido por el artículo 2o del reglamento CEE 2658/87. EI TARIC, a diferencia de su predecesor, no se encarga únicamente de la adopción del Arancel Aduanero Común, sino que además aborda cuestiones de las estadísticas del comercio exterior de la Comunidad ${ }^{92}$ y de las políticas de la Comunidad (comerciales, agrícolas o de otra índole) relativas a la importación o exportación de mercancías.

El mismo artículo $2^{\circ}$ establece que el TARIC estará basado en la Nomenclatura Combinada e incluirá:

a) las medidas que contiene el presente Reglamento;

b) las subdivisiones comunitarias complementarias, denominadas «subpartidas TARIC», necesarias para la ejecución de las medidas comunitarias específicas que figuran en el anexo II;

c) cualquier otro elemento informativo necesario para la aplicación o la gestión de los códigos TARIC y de los códigos adicionales contemplados en los apartados 2 y 3 del artículo 3;

d) los tipos de los derechos de aduana y los demás gravámenes sobre la exportación y la importación, incluyendo las exenciones de derechos y los tipos

\footnotetext{
${ }^{92}$ EI TARIC aborda la estadística del comercio exterior, con la ya estudiada NC, que constituye la base del arancel.
} 
preferenciales de derechos aplicables a la importación o la exportación de mercancías específicas;

e) las medidas aplicables a la importación o a la exportación de mercancías específicas que figuran en el anexo II.

Los tipos de los derechos de aduana y demás gravámenes a que hace alusión el inciso d) del artículo 2oㅡ , constituyen los elementos integrantes del Arancel Aduanero Común, que ampliamente describe el artículo 33 del Código Aduanero Modernizado (artículo 20 del CA) ${ }^{93}$. Dichos elementos y el Arancel Aduanero Común como tal, se encuentran recogidos en el anexo I de este reglamento, y se plasman más específicamente en el cuadro de derechos, el cual está conformado por cuatro columnas. La primera establece el "código de la nomenclatura combinada"; la segunda la "designación de la mercancía" que consiste en una breve descripción de la mercancía; la tercera el "Tipo del derecho convencional"94; y en la cuarta la "Unidad suplementaria" ${ }^{\text {". Este }}$

${ }^{93}$ Este artículo al igual que el inciso d), establece que el ARANCEL ADUANERO COMÚN estará compuesto por: la nomenclatura combinada; los tipos aplicables a los derechos de importación y/o exportación; medidas arancelarias preferenciales (díganse unilaterales o convencionales); medidas de suspensión, de reducción o exención, así como cualquier otro tipo de medidas arancelarias.

${ }^{94}$ Como ya hemos mencionado anteriormente aun cuando el título de la columna sea el de Derecho Convencional, no excluye de que en la misma se contengan otros tipos de derechos (autónomos, Autónomos especiales ó preferenciales unilaterales, etc.), los cuales estarán consignados a pie de página. Ver al respecto Reglamento 948/2009, Disposiciones preliminares, Título I, las disposiciones preliminares del, en específico Título I, apartado B .1.

${ }^{95}$ Se denomina Unidad suplementaria a la cuantificación de la mercancía en una medida de unidad, peso o volumen, sobre la que se determinará la base imponible, ya sea ad-valorem, especifica, mixta o compuesta. 
anexo, de conformidad al artículo 12 de la norma en comento, debe sustituirse cada año a más tardar el 31 de octubre y será aplicable a partir del 1 de enero del año siguiente, lo cual se hace mediante un reglamento de la comisión ${ }^{96}$.

Ejemplo:

\begin{tabular}{|c|c|c|c|}
\hline Codigo NC & Designación de la mercancía & $\begin{array}{l}\text { Tipo del derecho } \\
\text { convencional }(x)\end{array}$ & Unidad suplementaria \\
\hline 1 & 2 & 3 & 4 \\
\hline 0101 & Caballos, asnos, mulos y burdéganos, vivos: & & \\
\hline 010110 & - Reproductores de raza pura: & & \\
\hline 01011010 & 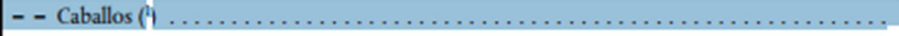 & exención & $\mathrm{p} / \mathrm{st}$ \\
\hline 01011090 & - - Los demás & 7.7 & $\mathrm{p} / \mathrm{st}$ \\
\hline 010190 & $\begin{array}{l}\text { - Los demás } \\
\text { - - Caballos: }\end{array}$ & & \\
\hline 01019011 & 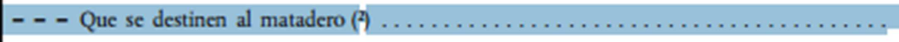 & exención & $\mathrm{p} / \mathrm{st}$ \\
\hline 01019019 & - - Los demás & 11,5 & $\mathrm{p} / \mathrm{st}$ \\
\hline 01019030 & - - Asnos & 7,7 & $\mathrm{p} / \mathrm{st}$ \\
\hline 01019090 & - - Mulos y burdéganos & 10,9 & $\mathrm{p} / \mathrm{st}$ \\
\hline S1m & 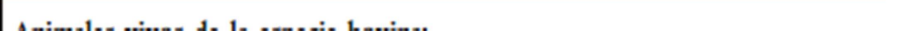 & & \\
\hline
\end{tabular}

La mayor innovación del TARIC frente a las normas que lo anteceden, es sin duda alguna, la incorporación en una sola norma de todas las disposiciones aplicables a un producto dado cuando éste se importe en el territorio aduanero de las Comunidades o, en determinados casos, sea exportado del mismo. Esto se logra a través del denominado código TARIC, que contiene además de la ya estudiada Nomenclatura Combinada, las "sub partidas TARIC" que son una novena y décima cifra, necesarias para la ejecución de las medidas

\footnotetext{
${ }^{96}$ La última modificación realizada durante el periodo de elaboración de esta tesis fue adoptada mediante el Reglamento (CE) no 948/2009 de la Comisión de 30 de septiembre de 2009.
} 
comunitarias específicas que figuran en el anexo ${ }^{997}$, además de los códigos adicionales contemplados en los apartados 2 y 3 del artículo $3^{98}$.

Puede observarse en el cuadro de derechos del anexo I, que ni las sub partidas TARIC, ni los códigos adicionales se encuentran recogidos en el cuadro de derechos del anexo I pues, como resulta lógico, requiere de una actualización constante, lo que difícilmente puede lograrse en un formato escrito o bajo el parámetro de un reglamento. Por esta razón el TARIC, de conformidad con lo previsto en el artículo 12.2 del reglamento, se contiene en una base de datos informatizada que se actualiza diariamente a través del Sistema de Difusión de

${ }^{97}$ El referido Anexo II está contenido en el reglamento 2505/92 de la Comisión, y contempla como medidas especificas: Suspensiones arancelarias, Contingentes arancelarios, Preferencias arancelarias (comprendidas las sometidas a un contingente o limite), Sistema de las preferencias generalizadas aplicables a los países en vías de desarrollo, Derechos antidumping y derechos compensatorios, Deducciones, Montantes compensatorios, Elementos móviles, Montantes compensatorios monetarios, Montantes compensatorios «adhesión» y derechos residuales, Valores unitarios, Precios de referencia y precios mínimo, Prohibiciones a la importación, Restricciones a la importación, Vigilancia a la importación, Mecanismo complementario de los intercambios, Prohibiciones a la exportación, Restricciones a la exportación, Vigilancia a la exportación, Restituciones a la exportación.

98 Estos Códigos adicionales de cuatro dígitos se utilizan para codificar: los derechos antidumping y los derechos compensatorios complejos, los elementos agrícolas, las sustancias farmacéuticas de la sección II, tercera parte de la NC, los productos CITES (Convención de Washington), precio de referencia del pescado, otras ciertas medidas a la importación o a la exportación para las cuales una subdivisión del código NC/TARIC es necesaria. Ver al respecto el Titulo II de la Comunicación de la Comisión 2003/C 103/01 de fecha 30 de abril de 2003. Pág. C 103/9. 
Datos $(\mathrm{DDS})^{99}$, brindando en todas las lenguas comunitarias información arancelaria actualizada a los Estados miembros, las aduanas y los operadores.

Ejemplo de consulta código TARIC y Códigos adicionales:

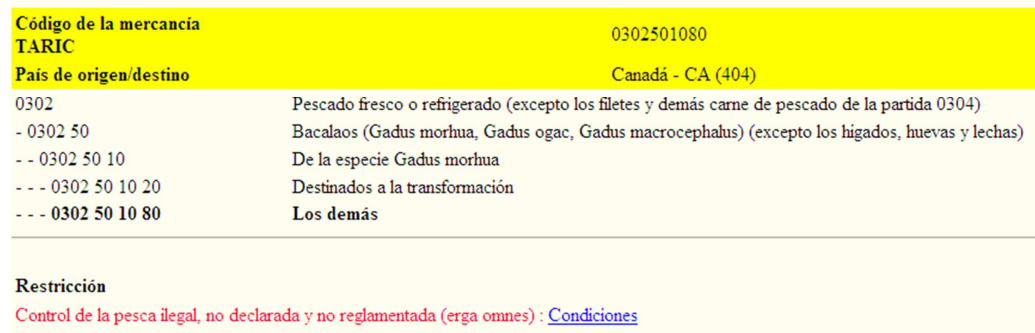

Importación

Derecho terceros paises : $12.00 \%$

En definitiva, el Reglamento 2658/87 es bastante innovador, al establecerse como norma marco y no como norma regulatoria, lo que facilita la actualización y vigencia del Arancel Aduanero Común. Destaca como su máximo logro la incorporación de las sub partidas y códigos adicionales TARIC que como vimos recopilan toda la normativa comunitaria y de los Estados Miembros relativa a las importaciones y exportaciones, dotando de mayor seguridad jurídica a los importadores y/o exportadores, ante la simplicidad de consulta, pudiendo en un mismo acto conocer la totalidad de gravámenes y/o restricciones a las que está sujeta la mercancía que se pretenda importar o exportar.

99 Consultable en la página de internet:

http://ec.europa.eu/taxation_customs/dds/tarhome_es.htm 


\subsubsection{El Código Aduanero Comunitario y el Código Aduanero Modernizado.}

En 1992, con el fin de integrar en un solo texto la dispersa normativa aduanera comunitaria, nace el código aduanero comunitario ${ }^{100}$. Este objetivo no se cumplió en su totalidad, pues sobra decir que la propia naturaleza de la materia aduanera imposibilita dicho $\mathrm{fin}^{101}$. No obstante, el código aduanero comunitario integra gran parte de la normativa aduanera relativa al intercambio de mercancías entre la Unión Europea y terceros países, esencialmente a lo que se refiere a: De manera general a la normativa aduanera, derechos y obligaciones de importadores y exportadores, representación ante la aduana, procedimientos de gestión, tipos de tributos aplicables a la importación y exportación, regímenes aduaneros, etc. ${ }^{102}$

\footnotetext{
${ }^{100}$ Así lo manifiesta expresamente el párrafo primero de consideraciones del propio código.

101 Ver al respecto a PELECHA ZOZAYA, F. El Código Aduanero Comunitario y su aplicación en España. 1를. Madrid: Marcial Pons, 1995. Páginas 11 a 16.

${ }^{102}$ Ver al respecto Fuente: Síntesis de legislación de la Unión Europea. Última modificación: 16.12.2005. http://europa.eu/scadplus/leg/es/lvb/111010.htm. «El código aduanero comunitario refiere principalmente a las disposiciones generales sobre los derechos y las obligaciones de las personas con respecto a la normativa aduanera (derecho de representación, información *, etc.), las disposiciones básicas que regulan el comercio de mercancías, referidas, sobre todo, a los derechos de importación o exportación, el valor en aduana ${ }_{-}^{*}$, el arancel aduanero de la CE y la clasificación arancelaria de las mercancías y su origen, las disposiciones aplicables a las mercancías introducidas en el territorio aduanero de la Comunidad, referidas, sobre todo, a la presentación en aduana, la declaración en aduana * , la obligación de dar un destino aduanero a las mercancías y el depósito temporal, las mercancías no comunitarias que hayan circulado al amparo de un régimen de tránsito, los destinos aduaneros, describiendo la inclusión de las mercancías en un régimen aduanero: el despacho a libre práctica, el tránsito, el depósito aduanero *, el perfeccionamiento activo * y pasivo * , la transformación bajo control aduanero *
} 
El 23 de abril del 2008 se promulgó el Reglamento 450/2008 del Parlamento Europeo y del Consejo, por el cual se establece el denominado Código aduanero modernizado ${ }^{103}$, que sustituirá totalmente al anterior Reglamento 2913/92, a más tardar el 24 de junio de 2013, fecha hasta la cual seguirán aplicándose simultáneamente en la forma que establece el artículo 188 del CAM. Son evidentes las similitudes entre ambos reglamentos en su estructura y contenido. El código aduanero modernizado se diferencia del anterior, por reducir y simplificar los procedimientos y regímenes aduaneros, la informatización de los procesos como la declaración en aduana, la autorización centralizada y el intercambio de información, etc. ${ }^{104}$

y la importación temporal y la exportación, y la introducción de mercancías en un zona franca o en un depósito franco *, la reexportación, la destrucción y el abandono de éstas en beneficio de la Hacienda Pública».

${ }^{103}$ En lo subsecuente nos referiremos al Código aduanero modernizado de manera abreviada por las siglas CAM.

${ }^{104}$ Garrigues. Boletín Aduanas. Madrid, Junio 2008. $\quad$ P. 3. http://www.garriguesmedioambiente.com/doc/AreaComunicacion/Publicaciones/Novedades/Bol etines/Boletin Aduanas 1062008 17062008120412.pdf «Racionalizar y reducir el número de procedimientos aduaneros y facilitar el seguimiento de mercancías. Reducir y simplificar los regímenes aduaneros con el fin de aumentar la competitividad de las empresas. Garantizar la progresiva informatización de todos los trámites aduaneros, con vistas a considerar el soporte papel como excepción y las declaraciones y tramitación electrónica como la norma. El establecimiento del intercambio de información electrónica entre autoridades aduaneras nacionales y con otras autoridades competentes. La promoción, en el marco de la cooperación y la asunción compartida de responsabilidades de las autoridades aduaneras, del concepto de "autorización centralizada", según el cual los operadores autorizados podrán declarar mercancías electrónicamente y pagar sus aranceles en el lugar donde estén establecidos, con independencia de cuál sea el lugar físico de su importación. El suministro de las bases para el desarrollo de los conceptos de "ventanilla única" o "servicio centralizado" según los cuales la información que suministren los operadores económicos será, siempre con respeto a las 


\subsubsection{La fundamentación del Código Aduanero y del Código Aduanero Modernizado.}

Como hemos venido realizando con anteriores ordenamientos estudiados, es preciso partir del origen que da sustento a la norma, es decir desde su fundamentación ya que, como hemos comentado en ocasiones anteriores, una inadecuada fundamentación puede conllevar a la nulidad de la norma adoptada como lo ha venido reiterando el Tribunal de Justicia de las Comunidades Europeas.

El fundamento de ambos Códigos Aduaneros, el de 1992 y el Código modernizado, se encuentra en las facultades de regulación exclusiva en los ámbitos de comercio exterior y Unión aduanera a que hace referencia el artículo 3.1 del TFUE, competencias que como vimos en el epígrafe correspondiente al establecimiento del Arancel Aduanero Común ${ }^{105}$, se deducían de los artículos 26 y 133 CE $^{106}$ (actuales 31 y 207 TFUE), amén de disposiciones en materia de protección de datos, intercambiada por las autoridades aduaneras y los demás organismos que participen en el control, permitiendo que el operador sólo tenga que presentar la información una vez y que las mercancías sean controladas al mismo tiempo y en el mismo lugar por dichas autoridades. Una mayor racionalización y armonización de los sistemas de garantía aduanera. Otras cuestiones: eliminación de las restricciones en materia de representación, posible ampliación de informaciones arancelarias vinculantes a otras áreas, establecimiento de principios comunes en el régimen sancionador, simplificación de las normas relativas a la no contracción, condonación o devolución de derechos, etc. ”

${ }^{105}$ Epígrafe 1.3 El establecimiento del Arancel Aduanero Común Y La Política Comercial Común. P. 15.

${ }^{106}$ Anteriores 28 y 113 del Tratado CE en los cuales se fundamente el Código aduanero de 1992, toda vez que el referido código es anterior al tratado de Ámsterdam (2 de octubre de 1997), que modifica la numeración del Tratado de la Comunidad Europea. 
dotar a la UE de facultades específicas en materia de comercio exterior, y más concretamente en materia arancelaria. Así pues, dada la naturaleza del Código Aduanero y de las materias que en el mismo se regulan, ambos artículos son de obligada inserción, constituyendo la base idónea para su fundamentación.

En los fundamentos tanto del Código actual como del modernizado encontramos un artículo que requiere especial atención: se trata del artículo 95 $\mathrm{CE}^{107}$ (antiguo artículo $100 \mathrm{~A}^{108}$, actual Artículo 114 TFUE), el cual es referente al proceso a seguir para la adopción de las medidas relativas a la aproximación de las disposiciones legales, reglamentarias y administrativas de los Estados miembros que tengan por objeto el establecimiento y el funcionamiento del mercado interior. Hasta cierto punto es lógico adoptar una norma aduanera con base en el citado artículo, pues la Unión aduanera y el mercado interior como vimos anteriormente, son consecuencia directa uno del otro, además de que los propios fines armonizadores del Código aduanero resultan congruentes con las potestades concedidas por el referido artículo.

\footnotetext{
${ }^{107}$ Artículo 95.1. No obstante lo dispuesto en el artículo 94 y salvo que el presente Tratado disponga otra cosa, se aplicarán las disposiciones siguientes para la consecución de los objetivos enunciados en el artículo 14. El Consejo, con arreglo al procedimiento previsto en el artículo 251 y previa consulta al Comité Económico y Social, adoptará las medidas relativas a la aproximación de las disposiciones legales, reglamentarias y administrativas de los Estados miembros que tengan por objeto el establecimiento y el funcionamiento del mercado interior.2. El apartado 1 no se aplicará a las disposiciones fiscales, a las disposiciones relativas a la libre circulación de personas ni a las relativas a los derechos e intereses de los trabajadores por cuenta ajena.

${ }^{108}$ Antes del Tratado de Ámsterdam
} 
No obstante el párrafo 2 de este artículo, proscribe de su aplicación a las disposiciones fiscales, lo cual nos plantea la disyuntiva de una posible nulidad del Código aduanero o bien la exclusión del carácter fiscal del derecho aduanero comunitario. Por desgracia y pese a su relevancia, inexplicablemente no ha sido abordado por la doctrina, salvo por alguna escueta referencia hecha por GALERA RODRIGO ${ }^{109}$, quien se inclina a favor de considerar la exclusión del derecho aduanero de la materia fiscal, sin hacer un estudio más detallado, de manera que consideramos de especial importancia abordarlo aquí.

La piedra angular del problema radica en la concepción de "disposiciones fiscales", en el marco del artículo 95.2 pues, si bien dentro de nuestra tradición latina, resultaría evidente el encuadrar como disposición fiscal a toda norma que regula los ingresos del Estado indistintamente de su naturaleza de derecho público o privado ${ }^{110}$, no necesariamente será así en el resto de las

109 GALERA RODRIGO, S. Derecho Aduanero Español y Comunitario: La Intervención Pública sobre el Comercio Exterior de Bienes. 1ํㅡㄹ Ed. Madrid: Civitas, 1995, P. 189. «El matiz es interesante, no tanto por las divergencias en el número de votos requeridos sino por la calificación de la materia aduanera que se deduce del procedimiento seguido para la aprobación del Código: la exclusión del carácter de «materia fiscal»

110 Vid al respecto GONZÁLEZ GARCÍA, E. "Derecho Fiscal, Derecho financiero y Hacienda Pública Revista de Derecho Financiero y Hacienda Pública", en Revista de Derecho Financiero y Hacienda Pública, № 104, 1973. «El Derecho Tributario y el Derecho Fiscal. Teóricamente este último sería más amplio que el primero, al contar en su haber con la regulación jurídica de los ingresos de Derecho Público y de Derecho Privado (no incluyo al gasto público y el Presupuesto, por la sencilla razón de que la regulación jurídica de estos sectores es relativamente moderna: su aparición hizo surgir otras tantas ramas jurídicas, y esta coexistencia múltiple forzó el nacimiento del Derecho Financiero como concepto comprensivo de todos ellos). Pero prácticamente su contenido es equiparable, pues tanto bajo el concepto amplio de Derecho Fiscal (relativo a los ingresos del Estado) como bajo el más preciso Derecho Tributario (relativo a los ingresos coactivos del Estado), la pieza central objeto del 
legislaciones de los Estados miembros de la UE, y en el sistema jurídico comunitario mismo, que se nutre de distintas tradiciones jurídicas.

EI TJCE en su sentencia de fecha 29 de abril de 2004, Comisión/Consejo (C338/01, Rec. p. 1-4829) establece en el apartado 67, lo siguiente: «procede interpretar los términos «disposiciones fiscales», que figuran en el artículo $95 \mathrm{CE}$, apartado 2, en el sentido de que abarcan no sólo las disposiciones que determinan los sujetos pasivos, las operaciones imponibles, la base imponible, los tipos impositivos y las exenciones de los impuestos directos e indirectos, sino también las relativas a los procedimientos de recaudación de éstos».

Debemos de entender en consecuencia que la denominación de "normas fiscales" a que hace alusión el apartado 2 del artículo 95 CE, debe emplearse a toda norma que regule material o formalmente cualquier tipo de tributo, pues si bien en la jurisprudencia antes citada se menciona expresamente el término impuestos, esto deriva de un uso indiscriminado del término "impuesto" por parte de las autoridades comunitarias ${ }^{111}$, y de una traducción literal del inglés ${ }^{112}$

estudio son los impuestos». TRIBUNAL FISCAL DE LA FEDERACIÓN. Jurisprudencia Plenaria de fecha16 de noviembre de 1937. "Debe atribuirse el carácter de fiscal a cualquier ingreso del Erario, a toda prestación pecuniaria a favor del Estado, sin que interese distinguir si el deudor es un particular, persona física o moral, algún establecimiento que tienen cierto aspecto funciones estatales, o algún ente público, ya sea entidad federativa u organismo municipal. Es decir, lo que da el carácter de fiscal a un crédito es la circunstancia de que el sujeto activo de él sea el poder público y no afecte el sujeto pasivo para precisar el carácter de la prestación adecuada; el sujeto activo y no el pasivo proporciona el criterio necesario para precisar si la relación jurídica es de naturaleza fiscal’».

${ }^{111}$ En el mismo sentido AMATUCCI, A. y GONZÁLEZ GARCÍA, E. "El concepto de Tributo", en: AMATUCCI, A. (Coordinador) Tratado de Derecho Tributario. 1를 Ed. Bogotá: Temis, 2001, Tomo Segundo, P. 4. En el pie de página 6 «Los ordenamientos disponen a menudo de 


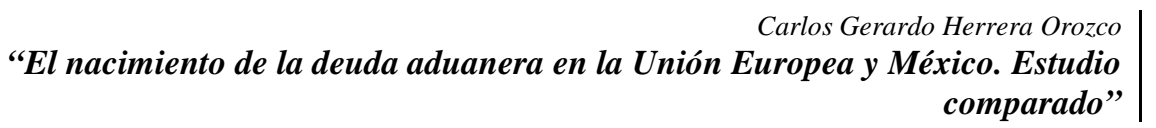

al español del término "tax" "113. Hay que tener en cuenta en primer lugar, que el término "tributo" en lengua inglesa no es equiparable en su significado ni en su aplicación a nuestra tradición jurídica, pues el término "tribute", que sería la traducción literal al inglés, en ninguna de sus acepciones hace referencia a la figura del tributo tal y como lo entendemos; quizás la acepción que más se acerca es aquella que lo entiende como: «pago otorgado por una nación más débil a otra nación más fuerte a cambio de protección», siendo por demás evidente la incompatibilidad terminológica ${ }^{114}$.

normas específicas para los tributos. A veces el legislador usa en vez de "tributo", otras expresiones, como "derechos", "cánones" y "tarifas" y define como "tasa" aquella que es un "impuesto". Menos rigurosa es la normativa comunitaria por la heterogeneidad de los ordenamientos nacionales y también por cuestiones lingüísticas». CASADO OLLERO, G. "Ordenamiento comunitario europeo y ordenamiento tributario interno". En JIMÉNEZ GONZÁLEZ, A (Coordinador). Grandes temas del Derecho tributario. 1르. Gd. Guadalajara, Jalisco, México: Unidad Editorial Gobierno del Estado de Jalisco, 1995, P. 173 «Respecto al significado y alcance del concepto de tributo, cuando éste se emplea en el ámbito comunitario; pues, sabido es $-y$ lo recuerda a menudo el TJCE- que las definiciones y clasificaciones propias de los Ordenamientos nacionales de los Estados miembros, no son pertinentes en derecho comunitario. $Y$, en efecto, la doctrina ha destacado en relación con las "figuras tributarias comunitarias", la inadecuación de las elaboraciones doctrinales sobre el instituto jurídico del tributo en el Derecho Interno».

${ }^{112}$ Idioma en el que se tramito el proceso original.

${ }^{113}$ Diccionario Inglés- Español Collins, «Tax (=contributtion) impuesto m, tributo» P. 1968

${ }^{114}$ Ver al respecto: GARNER, B.A. Black's Law Dictionary. Seventh edition.West group, St. Paul, Minn, U.S.A, 1999. «Tribute (trib-yoot), n. 1.An acknowledgment of gratitude or respect. 2. A contribution that a sovereign raises from its subjects to defray the expenses of state. $E$. Money paid by an inferior sovereign or state to superior on to secure the latter's friendship and protection". SIMPSON, J.A.; WEINER E.S.C. The Oxford English dictionary.Second edithion, Oxford, U.K., Oxford University Press, 1991.Volumen XVIII, P. 507. " 1. A tax or impost paid by one prince or state to another in acknowledgement of submission or as the Price of pace, 
En segundo lugar hay que recordar que en el idioma inglés bajo el concepto de "tax" se agrupa a la totalidad de tributos, hecho que se ratifica con la propia definición del término "tax" "15, la cual tiene concordancia con el concepto de tributo en nuestro sistema jurídico.

Todo ello corrobora que la consideración de normas fiscales no atañe únicamente a la figura tributaria de los impuestos, sino al conjunto de los tributos, reiterando por lo tanto que toda norma que regule material o formalmente un tributo será considerada como una norma de carácter fiscal y por ende proscrita de sustentarse en base al artículo 95 CE. Por lo que bajo

security, and protection; rent or homage paid in Money or an equivalent by a subject to his sovereign or a vassal to his lord. ...”

${ }^{115}$ Ver al respecto GARNER, B.A. Black's Law, Dictionary. Ob. Cit. P. 1469 «Tax, $n$. A monetary charge imposed by the government on persons, entities, or property to yield public revenue. Most broadly, the term embraces all governmental impositions on the person, property privileges, occupations, and enjoyment of the people, and includes duties, imposts, and excises. Although a tax is often thought of as being pecuniary in nature, it is not necessary payable in Money". MARTIN E.A. A Dictionary of law.Fourth edition. Oxford University Press, Great Britain, 1997. "A compulsory contribution to the States Funds it is levied either directly on the taxpayer by means of income tax, capital gains tax, in heritance tax, an corporation tax; or indirectly trough tax on purchases of goods and services (see value-added tax) and throuig various kinds of duty, road tax, stamp duty, and duties on betting and gaming». SIMPSON,J.A.; WEINER E.S.C. The Oxford English dictionary. Ob, Cit. Volumen XVII. P. 677 «Tax is the most inclusive term for these contributions, esp. When spoken of as the matter of taxation, and in such phrases as direct and indirect tax». Internal Revenue Service United States Departament of the Treasury http://www.irs.gov/app/understandingTaxes/student/glossary.jsp\#T «Taxes Required payments of money to governments that are used to provide public goods and services for the benefit of the community as a whole». 
estas premisas habría que considerar si el Código Aduanero se trata de una norma de carácter fiscal ${ }^{116}$.

\subsubsection{El Código aduanero como norma de Derecho Tributario.}

El primer rubro a evaluar para la determinación del carácter fiscal del CA, es el del carácter tributario de los derechos arancelarios que se regulan en el cuerpo del citado Código, pues como se desprende de lo ya visto, la naturaleza jurídica del ingreso que regula la norma será el factor determinante para decretar la naturaleza de la norma misma.

El carácter tributario de los derechos arancelarios ha sido aceptado por la mayoría de la doctrina, salvo la teoría que a principios del Siglo XX encabezara LABAND, para quien los impuestos arancelarios no son una obligación ex lege,

\footnotetext{
${ }^{116}$ En respaldo a éste razonamiento, encontramos en los alegatos de la misma sentencia C338/2001, el alegato vertido por el Consejo, en el párrafo 36 (Que a la postre es el que considero el TJCE como acertado), en el cual "afirma que son «disposiciones fiscales" en el sentido del artículo $95 \mathrm{CE}$, apartado 2, todas las medidas que regulan los ingresos públicos. Así, estos términos abarcan no sólo la definición y la descripción de los impuestos, sino también la forma en que éstos se liquidan y se recaudan. El término "fiscales" constituye una remisión al concepto de ingresos públicos. El Consejo destaca que, en la tercera parte del Tratado CE, dentro del título VI de ésta, el título en inglés del capítulo 2, "Tax provisions", acentúa más el carácter obligatorio de estos ingresos públicos. Pues bien, dicho carácter obligatorio, derivado de la prioridad y de las facultades tan especiales de que disponen los Estados miembros para liquidar y recaudar los ingresos fiscales, es una característica importante de los impuestos o de las cargas fiscales y se manifiesta con mayor claridad en la palabra "fiscal», utilizada en otras versiones lingüísticas. En principio, el "Derecho fiscal» se refiere tanto a la estructura como a la liquidación y recaudación de los impuestos. La interpretación del artículo 95 CE, apartado 2, debe tener en cuenta esta circunstancia y, en consecuencia, la prohibición contenida en él es aplicable a todas las disposiciones relativas a la estructura, a la liquidación y a la recaudación de los impuestos de que se trata».
} 
sino una carga sobre la mercancía, argumentando un poder de secuestro de las mercancías a favor del Estado que garantiza el pago del tributo; y una vez realizado el pago libera la mercancía del secuestro del Estado ${ }^{117}$. Teoría que como no podía ser de otra forma, fue combatida ampliamente quedando demostrado el error de su planteamiento, pues la relación jurídica no es entre el Estado y la mercancía, sino entre el Estado y el obligado al pago que sería el importador y/o exportador, siendo la mercancía únicamente una garantía del pago $^{118}$.

${ }^{117}$ LABAND, P. Le droit public de L'empire Allemand, Tome VI, Et Dernier Les Finances de I'Empire allemand. LARNAUDE, F. (Prol.) ; BOUYSSY (Trad.). 5a Ed. Paris : V. Giard \& E. Briere Libraires - éditeurs, 1904, P. 180 «l'obligation douanière ne pèse pas, á la manière d'une obligation, sur un débiteur déterminé, mais, á la manière d'un droit réel, sur une marchandise déterminée. Ce droit réel apparait tout d'abord en ce que l'autorité douanière prend la marchandise sous sa garde totale ou partielle ou sous son contrôle et qu'elle s'oppose á tout acte par lequel la marchandise serait mise dans le commerce intérieur. L'assujettissement des marchandises aux droits de douane donne lieu á un droit de rétention et de confiscation au profit de l'administration des douanes".

${ }^{118}$ BERLIRI, A. "La obligación tributaria aduanera". Aduanas... Ob. Cit. P. 6 «Cutrera y Giannini, quienes observaron que, si el Estado tiene potestad de percibir el derecho, tiene que haber también alguien obligado a pagarlo y que no se podía pensar tampoco en una relación entre el Estado y la mercancía a importar. Además, en bastantes casos, la figura del importador adquiere relieve incluso con respecto al derecho, lo cual, según los autores citados, demostraría cómo también en este caso se está en presencia de una obligación. (....) la tesis de Laband es desde luego inaceptable, en cuanto no podía ver en el derecho de aduanas sólo un gravamen real sobre la mercancía, una relación entre ésta y el Estado». CLAVIJO HERNÁNDEZ, F. "Impuestos Aduaneros". Curso de Derecho Ob. Cit. P. 751 y 752 . «El impuesto aduanero no es una "carga real», porque ésta es una categoría jurídico privada, y por tanto no "transportable» al derecho público, ya que si bien las situaciones pueden ser análogas, no podrán ser nunca similares, dada la diversidad de los fines e intereses de ambas ramas del Derecho"». Agrega que los impuestos aduaneros no se pueden considerar derechos reales en virtud que el Estado no tiene un dominio eminente sobre el bien, ya que el derecho de retención que ostenta el Estado, no es extrapolable al derecho de un crédito real, pues nos 
Después de LABAND, no ha existido controversia respecto del carácter tributario de los derechos arancelarios, centrándose el debate en la ubicación de los derechos arancelarios en una determinada figura tributaria; pues aun la teoría de la "carga" en el sentido técnico jurídico que encabeza BERLIRI, le niega exclusivamente el carácter impositivo, pero lo ubica dentro de la figura tributaria del gravamen fiscal ${ }^{119}$, más ya hablaremos con mayor profundidad del tema en epígrafes posteriores.

Ya sea partiendo de una definición gramatical de tributo ${ }^{120}$, o de definiciones más complejas como la que hace la $\mathrm{LGT}^{121}$ o la doctrina ${ }^{122}$, resulta innegable el

encontramos ante un ius in re alinea y no frente a un ius in re propia. Además que el impuesto aduanero contiene una obligación personal, frente al deudor; y «la mercancía se presenta únicamente como garantía del crédito aduanero».

${ }^{119}$ Aun cuando BERLIRI en el volumen II de sus Principios de Derecho Tributario conceptuaba a los derechos arancelarios como tasas, en su ya multicitado artículo "La obligación tributaria aduanera". Aduanas. № 272 -273. P. 9 Concluye: «Todos los argumentos que hemos examinado hasta ahora y que hacen dudar de la posibilidad de calificar el derecho de aduanas como un impuesto, están a favor de su inclusión entre los gravámenes fiscales».

120 Diccionario de la Real Academia de la Lengua Española. http://buscon.rae.es/drael/SrvltConsulta?TIPO BUS=3\&LEMA=tributo "Obligación dineraria establecida por la ley, cuyo importe se destina al sostenimiento de las cargas públicas»

121 Art. 2.1 LGT «Los tributos son los ingresos públicos que consisten en prestaciones pecuniarias exigidas por una Administración pública como consecuencia de la realización del supuesto de hecho al que la ley vincula el deber de contribuir, con el fin primordial de obtener los ingresos necesarios para el sostenimiento de los gastos públicos.

Los tributos, además de ser medios para obtener los recursos necesarios para el sostenimiento de los gastos públicos, podrán servir como instrumentos de la política económica general y atender a la realización de los principios y fines contenidos en la Constitución”.

${ }^{122}$ CALVO ORTEGA, R. Curso de derecho financiero I. Derecho tributario parte general. 6ª Ed. Madrid: Civitas, 2002, p. 55 «Prestación monetaria, coactiva, establecida por la ley y debida a 
carácter tributario de los derechos aduaneros comunitarios, al cumplir a cabalidad dos de las características esenciales del tributo generalmente aceptadas: su carácter de ingreso público coactivo y de obligación "ex lege".

Así, con relación a la primera característica señalada cabe decir que, como de todos es conocido, el presupuesto de la Unión está financiado con cargo a los recursos propios ${ }^{123}$, los cuales están integrados bien por los ingresos que una administración Pública por la realización de un hecho lícito que manifiesta capacidad económica». D`AMATI. "El derecho tributario" en: AMATUCCI, A.(Coordinador) Tratado de

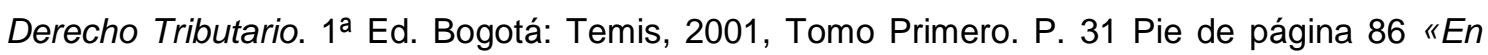
nuestro concepto, el tributo constituye un medio técnico (es decir, un instrumento operativo) para contribuir en forma coactiva y proporcionalmente al sostenimiento del conjunto de las cargas tributarias, y para hacer conseguir al ente supranacional, nacional o regional, la entrada de ingresos públicos derivados del cumplimiento de la obligación tributaria». JARACH, D. El hecho imponible teoría general del derecho tributario sustantivo. 3를 Ed. Buenos Aires: AbeledoPerrot, 1982. P.11-12 «El tributo es una prestación pecuniaria, objeto de una relación cuya fuente es la ley, entre dos sujetos: de un lado el que tiene derecho a exigir la prestación, el acreedor del tributo, es decir el Estado o la otra entidad pública que efectivamente, por virtud de una ley positiva, posee ese derecho, y de otro lado el deudor, o los deudores, quienes están obligados a cumplir la prestación pecuniaria». MARTÍN QUERARLT,J. LOZANO SERRANO, C. y OTROS. Curso de derecho financiero y tributario. 13 Ed. Madrid: Tecnos, 2002. P. 78 «El tributo es un ingreso público de derecho público, obtenido por un ente público, titular de un derecho de crédito frente al contribuyente obligado, como consecuencia de la aplicación de la ley a un hecho indicativo de capacidad económica, que no constituye la sanción de un ilícito".

${ }^{123}$ Artículo 311 TFUE (antiguo artículo 269 TCE) La Unión se dotará de los medios necesarios para alcanzar sus objetivos y para llevar a cabo sus políticas.

Sin perjuicio del concurso de otros ingresos, el presupuesto será financiado íntegramente con cargo a los recursos propios. Comisión Europea. Síntesis de legislación. Bruselas. Última modificación: 04.09.2007. Consultada 20/08/2010. Disponible en la web: http://europa.eu/legislation summaries/budget//34011 es.htm «Los recursos propios pueden definirse como medios de financiación propios e independientes de los Estados miembros. Se trata de ingresos destinados definitivamente a la Comunidad para financiar su presupuesto y a los que tiene derecho sin que las autoridades nacionales deban aprobarlos. Así, los Estados miembros se ven obligados a poner a disposición de la Comunidad fondos destinados al 
percibe la Unión por el ejercicio de sus competencias conferidas en los Tratados y en la aplicación de las políticas comunitarias (recursos propios tradicionales $)^{124}$, o bien por aportaciones de los Estados de un porcentaje del IVA recaudado por los Estados y de un porcentaje del Producto Nacional Bruto (recursos propios de equilibrio).

Los derechos arancelarios, como resulta evidente, forman parte de los recursos propios tradicionales con los que se financia el gasto comunitario, así lo manifiesta el artículo 2.1 a) de la Decisión Del Consejo de 7 de junio de 2007 sobre el sistema de recursos propios de las Comunidades Europeas $(2007 / 436 / C E \text {, Euratom })^{125}$, resultando innegable su carácter de ingreso público comunitario $^{126}$.

presupuesto». FALCÓN Y TELLA, R. Introducción al derecho financiero y tributario de las Comunidades Europeas. 1a Ed. Madrid: Civitas, 1988. P111 «En sentido amplio, podemos calificar como recursos tributarios propios de las Comunidades todos aquellos tributos establecidos y gestionados por los órganos comunitarios, es decir, todos los tributos respecto a los que las competencias normativas, las facultades de gestión y la titularidad de las sumas recaudadas corresponde íntegramente a las Comunidades».

${ }^{124}$ http://europa.eu/legislation summaries/budget/34011 es.htm «Los recursos propios tradicionales (RPT) se consideran como recursos propios "por naturaleza", ya que se trata de ingresos recaudados en el marco de las políticas comunitarias y no procedentes de los Estados miembros en concepto de contribuciones nacionales».

125 Decisión del Consejo de 7 de junio de 2007 sobre el sistema de recursos propios de las Comunidades Europeas (2007/436/CE, Euratom) «Artículo 2. 1. Constituyen recursos propios, consignados en el presupuesto de la Unión Europea, los siguientes ingresos:

a) exacciones, primas, montantes suplementarios o compensatorios, importes o elementos adicionales, derechos del Arancel Aduanero Común y otros derechos que hayan fijado 0 puedan fijar las instituciones de las Comunidades en los intercambios comerciales con terceros países, derechos de aduana sobre los productos regulados por el Tratado constitutivo de la 
En cuanto a su carácter de Obligación "ex Lege", la coercitividad de los derechos arancelarios está en relación directa con su establecimiento mediante Reglamento comunitario ${ }^{127}$, que como de todos es sabido correspondería a la figura de una Ley estatal o de derecho interno comunitaria ${ }^{128}$, pues procede de un acto legislativo del Parlamento que conjuntamente con el Consejo, adoptan una norma de alcance general, obligatoria en todos sus elementos y

Comunidad Europea del Carbón y del Acero, ya expirado, así como cotizaciones y otros derechos previstos en el marco de la organización común de mercados en el sector del azúcar;».

${ }^{126}$ CLAVIJO HERNÁNDEZ, F. "Impuestos Aduaneros". Curso de Derecho Ob. Cit. P. 753 «Los derechos de aduana a la importación son, en nuestro ordenamiento jurídico, un ingreso de Derecho público percibido por las Comunidades Europeas en el ejercicio de su poder financiero, que se hacen efectivos, (...) mediante el desarrollo de la actividad financiera de la Administración de los Estados miembros, a los que corresponde el ejercicio- no la titularidadde las potestades de gestión tributaria».

${ }^{127}$ Los elementos esenciales de los derechos arancelarios se encuentran normados como veremos en párrafos siguientes en el Código aduanero, y la tarifa se establece en el ya multicitado reglamento $2658 / 87$.

${ }^{128}$ Tal y como se les pretendía nombrar en la fallida Constitución Europea en su artículo I-33. Para KLAUS-DIETER BORCHARDT, en la ya citada obra "El ABC del Derecho Comunitario". Pág. 65 "Las similitudes entre estos actos jurídicos y las leyes nacionales saltan a la vista. En la medida en que se adopten en régimen de codecisión con el Parlamento Europeo (según el llamado procedimiento de codecisión, que se describe en el siguiente capítulo), pueden denominarse «leyes europeas». En el mismo sentido LIÑAN NOGUERAS, D. en Instituciones y Derecho de la Unión Europea. 3" Ed, Madrid: Tecnos, 2003 P. 355 "Se trata indiscutiblemente del instrumento de regulación jurídica más acabado dentro del sistema comunitario. Buena parte de la doctrina, en particular la más empeñada en hacer entrar el sistema comunitario dentro de los sistemas de fuentes estatales, resaltan aquellos caracteres de este tipo normativo más similares a los de las leyes (generalidad, abstracción, efectos erga omnes y otros caracteres con los que la teoría tradicional cualifica a la ley)». 
directamente aplicable en cada Estado miembro ${ }^{129}$. Por lo que al establecer por este medio el supuesto general que da origen a la obligación tributaria (Hecho imponible), se cumple con el requisito de legalidad dotando a los derechos arancelarios de la obligatoriedad y coercitividad que reviste a todo tributo.

Por otro lado, partiendo del reconocimiento del carácter tributario de los derechos de aduana, podemos considerar al Código aduanero como una norma tributaria de carácter material y formal. Lo primero, en tanto en su Título III $^{130}$ determina los elementos cualitativos y subjetivos de los derechos arancelarios. Elementos que, como apuntaba PELECHA ZOZAYA, se encuentran expresados en términos distintos a los tradicionales del Derecho tributario $^{131}$ por lo que no se emplean términos como "hecho imponible", aunque sí encontramos el origen de la deuda aduanera y una descripción del supuesto de Ley que da lugar al nacimiento a la obligación dineraria, lo que en términos prácticos es lo mismo al hecho imponible ${ }^{132}$. De igual forma se describe a los sujetos pasivos de la relación aduanera bajo el concepto de

\footnotetext{
${ }^{129}$ Artículo 288 TFUE (antiguo artículo 249 TCE)... El reglamento tendrá un alcance general. Será obligatorio en todos sus elementos y directamente aplicable en cada Estado miembro.

${ }^{130}$ TÍTULO III. DEUDA ADUANERA Y GARANTÍAS

${ }^{131}$ PELECHA ZOZAYA, F. El Código aduanero comunitario y su aplicación en España. Ob. Cit. P. 18 "También se buscará en vano en el CA o en su RA conceptos tales como el hecho imponible, base imponible, tipo, sujeto pasivo, etc., por más que la regulación de los mismos aunque no de todos-'pueda encontrarse en aquéllos, aunque sin utilizar esas expresiones, a las que, por lo demás, tampoco es muy aficionado, que digamos, el sector de la doctrina española que ha tratado el Derecho aduanero, quizá por haberse sabido librar de la arcaica terminología y sistemática de buena parte de la normativa aduanera española».

${ }^{132}$ Capítulo I. Origen de la deuda aduanera. Artículos 44 al 49 del CAM.
} 
"deudor", establece el momento en que se origina la obligación, o lo que es lo mismo en términos tributarios tradicionales el "Devengo" y, además contiene un capítulo específico de "Exención de derechos de importación"133.

En lo que respecta a su carácter de norma tributaria formal, se evidencia tanto desde los propios considerandos del Código de 1992 como del modernizado, los cuales justifican su adopción en virtud de la necesidad crear, agrupar y, en el caso de la última de las normas referidas, de mejorar las normas de recaudación de los tributos aduaneros, englobando los distintos regímenes aduaneros, las declaraciones y los trámites aduaneros, en diversos títulos y capítulos. Así podemos observar en el capítulo 2 del Título I, lo relativo a los derechos y obligaciones de las personas en el marco de legislación aduanera, o el Título III referente a los elementos en que se basa la aplicación de los derechos de importación o exportación y otras medidas en el comercio exterior. Por lo que, al quedar demostrado que el Código aduanero se refiere a disposiciones fiscales en los términos del apartado 67 de la multicitada sentencia del TJCE, de fecha 29 de abril de 2004, Comisión/Consejo (C338/01, Rec. p. I-4829), se concluye de conformidad al apartado $94^{134}$ dela misma sentencia que el artículo $95 \mathrm{CE}$, no es la base jurídica adecuada para la

\footnotetext{
${ }^{133}$ Artículos 130 al 134 del CAM.

${ }^{134}$ Sentencia del TJCE, de fecha 29 de abril de 2004, Comisión/Consejo (C-338/01, Rec. p. I4829). Apartado 94 «Habida cuenta de las consideraciones anteriores, procede declarar que la Directiva 2001/44 se refiere a "disposiciones fiscales» en el sentido del artículo 95 CE, apartado 2, por lo que este artículo no puede constituir la base jurídica adecuada para la adopción de dicha Directiva».
} 
adopción de los códigos aduaneros tanto de 1992 como el modernizado de 2008, debiendo haber sido adoptado con base en los artículos 93 y 94, en virtud del carácter impositivo de los derechos arancelarios. En consecuencia, debería de decretarse la nulidad de ambos ordenamientos en los términos de artículo 264 del TFUE. 


\subsection{El Derecho aduanero de los Estados miembros.}

Es este sin duda el punto más desconocido del Derecho aduanero comunitario pues, si partimos de la exclusividad de la materia aduanera a favor de la Unión Europea, descartaríamos de entrada toda participación legislativa de los Estados miembros. Sin embargo esto no es así de tajante, Si bien es cierto que la materia aduanera es exclusiva de la Unión y que el artículo 2.1 del TFUE, establece que «Cuando los Tratados atribuyan a la Unión una competencia exclusiva en un ámbito determinado, sólo la Unión podrá legislar y adoptar actos jurídicamente vinculantes», también es cierto que el mismo numeral en el mismo párrafo, abre la posibilidad de que los Estados miembros legislen en materias exclusivas de la Unión, condicionándolos a la permisión expresa de la Unión o la aplicación de actos de la Unión ${ }^{135}$.

Como hemos visto a lo largo de este capítulo, la Unión ha legislado en torno a la parte sustantiva del derecho aduanero, es decir, nacimiento de la obligación aduanera, regímenes, sujetos pasivos, tarifa, etc. La parte procedimental la ha delegado a los Estados miembros en virtud de que son estos los encargados de la gestión y recaudación de los tributos aduaneros, centrándose sobre todo en la parte de organización, estatutos de las autoridades aduaneras, sanciones y procesos de impugnación.

\footnotetext{
135 TFUE «Artículo 2.1 Cuando los Tratados atribuyan a la Unión una competencia exclusiva en un ámbito determinado, sólo la Unión podrá legislar y adoptar actos jurídicamente vinculantes, mientras que los Estados miembros, en cuanto tales, únicamente podrán hacerlo si son facultados por la Unión o para aplicar actos de la Unión”.
} 
Muchas de estas competencias normativas en materia aduanera de las que aun gozan los Estados, se encuentran dispersas en sus sistemas jurídicos, sin estar en muchos de los casos codificadas. Salvo el caso de Francia que si tiene un Código aduanero ${ }^{136}$ el resto de los Estados miembros, en el mejor de los casos, tienen alguna legislación basada en directivas anteriores a la entrada en vigor del Código aduanero comunitario ${ }^{137}$, lo que suscita incertidumbre jurídica en el ámbito del comercio exterior y pudiera derivar en un desequilibrio de la Unión.

Resulta hasta cierto punto incomprensible el que siendo la Unión aduanera uno de los puntos clave de la Unión Europea, no se haya concentrado tanto legislativa como operativamente en ella todo lo relativo a la tramitación aduanera. Se podría presuponer que es cuestión de tiempo para que esto

${ }^{136}$ BERR, J.C. y TRÉMEAU, H. Le droit douanier Communautaire et national. 6a Ed. Paris : Economica, 2004, P. 63 "La subsistance d'un Code national en matière douanière peut sembler en elle -même difficilement compatible avec l'achèvement du marché intérieur. D'un point de vue abstrait, la mise en œuvre du Code des douanes communautaire aurait du Code des douanes communautaire aurait dû mettre fin á une coexistence qu'imposait jusqu'alors dans une certaine mesure la nature de certains normes (directives) et qui justifiât l'existence d'un corps de règles nationales. D'un point de vue pratique, il convient de relativiser ce point de vue : le code national traite en effet de nombreuses questions qui ne sont pas abordées dans le code communautaire (organisation et fonctionnement du service des Douanes, fiscalité pétrolière, régime administratif des navires, taxes diverses, contentieux) et qui demeurent de la compétence des autorités nationales».

${ }^{137}$ Caso español con el Real decreto 1299/86. Considero relevante señalar que en el 2005 existió una propuesta de crear un Código aduanero español, propuesta encabezada por el ex secretario de Estado GIMENEZ REYNA, que al final de cuentas no tuvo consecuencia alguna. 
ocurra, pero sin embargo en la práctica no lo vemos tan cercano, aun cuando esto ya ha sido objeto de una reclamación internacional ${ }^{138}$.

En septiembre de 2004, Estados Unidos interpuso ante la Organización Mundial de Comercio una solicitud de solución de diferencias, a la que se sumaron otros países ${ }^{139}$, argumentando: «que las Comunidades Europeas ("CE") aplican las leyes, reglamentos, decisiones judiciales y disposiciones administrativas a que se refiere el párrafo 1 del artículo $X$ del Acuerdo General sobre Aranceles Aduaneros y Comercio de 1994 ("GATT de 1994") no es uniforme, imparcial y razonable, y, por lo tanto, es incompatible con el párrafo 3 a) del artículo $X$ del GATT de 1994» ${ }^{140}$.

Este proceso nos servirá de base para el planteamiento del problema, pues toca incisivamente el problema planteado en los primeros párrafos de este

${ }^{138}$ GALERA RODRIGO, S. Derecho Aduanero Español y Comunitario. Ob. Cit. P. 157 «sin embargo, como veremos, no pueden considerarse los anteriores ámbitos de competencias nacional exclusiva, ejercitada sin interferencias de la legislación o de la actividad de los órganos comunitarios (Se refiere a la Organización y estatuto de la Administración Aduanera, y Procedimientos e instancias litigiosas). Por el contrario, se observa un creciente interés comunitario en estas materias, en razón a su conexidad con los ámbitos materiales de competencia comunitaria, especialmente la aduanera. Ello manifiesta una progresión hacia la comunitarización completa de la intervención en materia aduanera, incluyéndose no sólo el derecho sustantivo sino también los aspectos orgánicos, procedimentales y contenciosos».

${ }^{139}$ Argentina; Australia; Brasil; China; Taipei Chino; Hong Kong, China; India; Japón; República de Corea.

${ }^{140}$ Ver comunicación, de fecha 13 de enero de 2005, dirigida por la delegación de los Estados Unidos a la Presidenta del Órgano de Solución de Diferencias de la Organización Mundial de Comercio. Disponible en la página Web: http://www.wto.org/spanish/tratop_s/dispu_s/cases_s/ds315_s.htm\#top 
epígrafe: la falta de una normativa aduanera comunitaria única respecto a la parte formal, procesal y penal del derecho aduanero.

Los alegatos presentados por la Comunidad Europea podrían resumirse en tres puntos concretos: destacar que el Tratado de la OMC, no obliga a una armonización de la normativa aduanera de sus miembros ${ }^{141}$, el respeto de la soberanía de la Unión y en la concepción del "federalismo ejecutivo"142, explicando en su primera Comunicación escrita el proceso de supervisión del Comité del Código aduanero en la aplicación de los Tratados y como responsable de la reglamentación aduanera ${ }^{143}$, con lo cual intenta justificar la Unidad en la aplicación de la normativa comunitaria.

La declaración final de la Segunda declaración oral de los Estados Unidos, contenida en el informe del Grupo Especial de fecha 13 de noviembre de 2006,

${ }^{141}$ INFORME GRUPO ESPECIAL. Primera Comunicación Escrita de la Comunidad Europea. Apartado. 4.50 «El párrafo 3 del artículo X del GATT es una disposición que establece normas mínimas para la aplicación de la legislación aduanera y no una base jurídica para la armonización de los sistemas de administración aduanera de los Miembros de la OMC».

142 INFORME GRUPO ESPECIAL. Primera Comunicación Escrita de la Comunidad Europea. Apartado. 4.54 "No obstante, con la excepción de un número reducido de esferas normativas, las CE no aplican el derecho comunitario por medio de una administración a nivel de las CE, sino que la ejecución de las leyes comunitarias se lleva a cabo por medio de las administraciones nacionales de los Estados miembros y, de forma análoga, por medio de los tribunales de esos Estados. Este principio de administración por medio de los Estados miembros puede calificarse de "federalismo ejecutivo"».

143 Ver. INFORME GRUPO ESPECIAL. Primera Comunicación Escrita de la Comunidad Europea. Apartados 4.99 a 4.107 
párrafos 4.914 a $4.917^{144}$, pone el dedo en la llaga de la problemática, pues plantea de forma clara y concreta las disparidades que se dan en las distintas

\footnotetext{
$\overline{144}$ «La manera en que las CE han argumentado la presente diferencia da la impresión de que las cuestiones son mucho más complicadas de lo que en realidad son. Las CE han sostenido en ocasiones que la diferencia versa sobre cuestiones filosóficas más amplias, tales como diferencias en las doctrinas que apuntalan el federalismo en los Estados Unidos y en las CE. En otras ocasiones han sostenido que la diferencia versa sobre la minucia de si una u otra autoridad aduanera de las CE decidió correctamente una cuestión concreta. Es fácil perderse en las idas y venidas entre la teoría política y los misterios técnicos, pero cuando se despejan los argumentos sobre cuestiones que no guardan relación con esta diferencia, el asunto en realidad es muy sencillo.
}

Con respecto al párrafo 3 a) del artículo X, las CE están obligadas a aplicar sus leyes aduaneras de manera uniforme. En la práctica, las aplican mediante 25 autoridades distintas en diferentes partes de su territorio. Las decisiones de una autoridad no obligan a ninguna de las demás autoridades. Si la autoridad comunitaria en España emite información arancelaria vinculante mediante la que se clasifica un producto de una manera determinada, la autoridad comunitaria en Alemania no está obligada a dar valor alguno a esa decisión (salvo en el caso muy limitado en que el titular invoque la IAV). Si un tercero insta a la autoridad comunitaria en Alemania a seguir la decisión de clasificación de la autoridad comunitaria en España, aunque ese tercero sea una filial del titular, la autoridad comunitaria en Alemania no está obligada a hacerlo. En resumen, una parte del mecanismo de administración de aduanas de las CE no está obligada a actuar de manera coherente con otras partes de ese mecanismo.

Las CE afirman que no es así. Declaran que existen procedimientos e instituciones para garantizar que distintas partes del mecanismo de administración de aduanas de las CE actúen de manera uniforme. Sin embargo, esta afirmación no resiste el análisis. Con una excepción (los recursos ante los tribunales de los Estados miembros), los procedimientos e instituciones son obligaciones de carácter general, orientaciones no vinculantes y mecanismos discrecionales. Este aspecto quedó bien ilustrado en la respuesta preliminar de las CE a la pregunta 164 a) del Grupo Especial. Cuando se les pidió que se refirieran a la observación de que las CE no aluden a medidas que hagan operativo el artículo 10 del Tratado de la CE -el deber general de cooperación de los Estados miembros- en el contexto de la administración de aduanas, las CE siguieron sin mencionar medidas específicas. Dijeron simplemente que el deber de cooperación establecido en el artículo 10 es una obligación jurídica vinculante que puede exigirse mediante el procedimiento por incumplimiento. Las CE afirman reiteradamente que se pueden remitir asuntos al Comité del Código Aduanero, que se pueden plantear reclamaciones por infracción, que los Estados miembros pueden dar deferencia a las 
aduanas, concretamente la falta de obligatoriedad de los criterios adoptados por un Estado en materia aduanera para ser aplicado por otro Estado miembro, que por obvias razones crea disparidad en la aplicación de la norma.

En apoyo de lo anterior resulta de lo más ejemplificativo el cuadro comparativo presentado por Estados Unidos, respecto a las diferencias de aplicación de la normativa aduanera que se pueden dar de un Estado a otro de la Comunidad.

decisiones de otros Estados miembros. Sin embargo, lo esencial es que todos estos denominados instrumentos son discrecionales.

Al no existir procedimientos ni instituciones que obliguen a las distintas partes del mecanismo comunitario de administración de aduanas a actuar de manera uniforme, el diseño y la estructura del sistema comunitario de administración de aduanas es tal que necesariamente da lugar a la aplicación no uniforme. Incluso el único instrumento obligatorio al que se han referido las CE no resuelve este problema. Incluso cuando se enfrenta a pruebas directas de que existe divergencia en la aplicación de la legislación aduanera en los Estados miembros, un tribunal de un Estado miembro no está obligado a remitir la cuestión al TJCE». 


\begin{tabular}{|c|c|c|c|c|}
\hline $\begin{array}{l}\text { Estado } \\
\text { miembro }\end{array}$ & $\begin{array}{c}\text { Requisitos } \\
\text { previos al } \\
\text { levante }\end{array}$ & $\begin{array}{c}\text { Intervención de } \\
\text { la aduana antes } \\
\text { del levante }\end{array}$ & $\begin{array}{c}\text { Requisitos } \\
\text { posteriores al } \\
\text { levante }\end{array}$ & $\begin{array}{l}\text { Requisitos sobre } \\
\text { conservación de } \\
\text { comprobantes }\end{array}$ \\
\hline Reino Unido & $\begin{array}{l}\text { Los datos del } \\
\text { manifiesto se } \\
\text { presentan por vía } \\
\text { telemática a la } \\
\text { aduana sin } \\
\text { modificarlos. }\end{array}$ & Ninguna & $\begin{array}{l}\text { Se transmiten a la } \\
\text { aduana por vía } \\
\text { telemática datos } \\
\text { complementarios } \\
\text { sobre la } \\
\text { clasificación, la } \\
\text { valoración y el } \\
\text { origen. }\end{array}$ & $\begin{array}{l}\text { El importador } \\
\text { debe conservar } \\
\text { los comprobantes } \\
\text { durante } 4 \text { años. }\end{array}$ \\
\hline Francia & $\begin{array}{l}\text { Los datos del } \\
\text { manifiesto se } \\
\text { complementan } \\
\text { con otros sobre la } \\
\text { clasificación, la } \\
\text { valoración, etc. y } \\
\text { se registran en el } \\
\text { sistema de } \\
\text { inventario del } \\
\text { importador; el } \\
\text { importador } \\
\text { transmite la } \\
\text { declaración inicial } \\
\text { a la aduana. }\end{array}$ & $\begin{array}{l}\text { Se puede hacer } \\
\text { una inspección } \\
\text { dentro de un } \\
\text { plazo } \\
\text { determinado } \\
\text { antes del levante. }\end{array}$ & $\begin{array}{c}\text { Se deben } \\
\text { presentar a la } \\
\text { aduana en forma } \\
\text { impresa datos } \\
\text { complementarios, } \\
\text { entre ellos } \\
\text { comprobantes, el } \\
\text { formulario de } \\
\text { valoración DV1, } \\
\text { facturas y } \\
\text { certificados. }\end{array}$ & \\
\hline
\end{tabular}




\begin{tabular}{|c|c|c|c|c|}
\hline $\begin{array}{l}\text { Estado } \\
\text { miembro }\end{array}$ & $\begin{array}{c}\text { Requisitos } \\
\text { previos al } \\
\text { levante }\end{array}$ & $\begin{array}{l}\text { Intervención de } \\
\text { la aduana antes } \\
\text { del levante }\end{array}$ & $\begin{array}{c}\text { Requisitos } \\
\text { posteriores al } \\
\text { levante }\end{array}$ & $\begin{array}{l}\text { Requisitos sobre } \\
\text { conservación de } \\
\text { comprobantes }\end{array}$ \\
\hline Alemania & $\begin{array}{c}\text { Se transmiten a la } \\
\text { aduana los datos } \\
\text { del manifiesto, } \\
\text { incluida la } \\
\text { traducción al } \\
\text { alemán de la } \\
\text { descripción de las } \\
\text { mercancías; la } \\
\text { declaración } \\
\text { inicial, con } \\
\text { información sobre } \\
\text { la clasificación, la } \\
\text { valoración y el } \\
\text { origen, se } \\
\text { presenta a la } \\
\text { aduana. }\end{array}$ & $\begin{array}{l}\text { Se puede hacer } \\
\text { una inspección } \\
\text { dentro de un } \\
\text { plazo } \\
\text { determinado } \\
\text { antes del levante. }\end{array}$ & $\begin{array}{c}\text { Se deben } \\
\text { presentar a la } \\
\text { aduana datos } \\
\text { complementarios, } \\
\text { entre ellos } \\
\text { comprobantes, el } \\
\text { formulario de } \\
\text { valoración DV1, } \\
\text { facturas y } \\
\text { certificados. }\end{array}$ & $\begin{array}{c}\text { El importador } \\
\text { debe conservar } \\
\text { los comprobantes } \\
\text { durante } 6 \text { años. }\end{array}$ \\
\hline
\end{tabular}




\begin{tabular}{|c|c|c|c|c|}
\hline $\begin{array}{l}\text { Estado } \\
\text { miembro }\end{array}$ & $\begin{array}{c}\text { Requisitos } \\
\text { previos al } \\
\text { levante }\end{array}$ & $\begin{array}{l}\text { Intervención de } \\
\text { la aduana antes } \\
\text { del levante }\end{array}$ & $\begin{array}{c}\text { Requisitos } \\
\text { posteriores al } \\
\text { levante }\end{array}$ & $\begin{array}{l}\text { Requisitos sobre } \\
\text { conservación de } \\
\text { comprobantes }\end{array}$ \\
\hline Italia & $\begin{array}{l}\text { Se transmiten a la } \\
\text { aduana los datos } \\
\text { del manifiesto. }\end{array}$ & $\begin{array}{l}\text { Se puede hacer } \\
\text { una inspección } \\
\text { dentro del plazo } \\
\text { de } 1 \text { hora. }\end{array}$ & $\begin{array}{c}\text { La declaración } \\
\text { complementaria } \\
\text { se transmite por } \\
\text { vía telemática; no } \\
\text { se exige el } \\
\text { formulario de } \\
\text { valoración DV1. }\end{array}$ & $\begin{array}{l}\text { El importador } \\
\text { debe conservar } \\
\text { los comprobantes } \\
\text { durante } 5 \text { años. }\end{array}$ \\
\hline Países Bajos & $\begin{array}{c}\text { La declaración } \\
\text { inicial se hace } \\
\text { con una } \\
\text { anotación en el } \\
\text { sistema de } \\
\text { inventario del } \\
\text { importador; el } \\
\text { contenido de la } \\
\text { declaración inicial } \\
\text { se negocia a nivel } \\
\text { local. }\end{array}$ & $\begin{array}{l}\text { Se puede hacer } \\
\text { una inspección } \\
\text { dentro de un } \\
\text { plazo } \\
\text { determinado } \\
\text { antes del levante. }\end{array}$ & $\begin{array}{c}\text { El formulario de } \\
\text { valoración DV1 se } \\
\text { transmite por vía } \\
\text { telemática. Con } \\
\text { la declaración } \\
\text { suplementaria se } \\
\text { exigen algunos } \\
\text { documentos (por } \\
\text { ejemplo, licencias } \\
\text { y certificados que } \\
\text { prueban el } \\
\text { derecho a un trato } \\
\text { arancelario } \\
\text { preferencial, pero } \\
\text { no se exigen } \\
\text { facturas ni }\end{array}$ & $\begin{array}{c}\text { El importador } \\
\text { debe conservar } \\
\text { los comprobantes } \\
\text { durante } 10 \text { años. }\end{array}$ \\
\hline
\end{tabular}




\begin{tabular}{|c|c|c|c|l|}
\hline Estado & Requisitos & Intervención de & Requisitos \\
miembro & previos al & la aduana antes & posteriores al \\
levante & del levante & levante & $\begin{array}{c}\text { conservación de } \\
\text { comprobantes }\end{array}$ \\
\hline & & & $\begin{array}{c}\text { conocimientos de } \\
\text { embarque. }\end{array}$ & \\
& & & & \\
\hline
\end{tabular}

Con este planteamiento no pretendo inclinarme doctrinalmente en favor de alguna de las partes en el conflicto sino simplemente plantear una realidad de una problemática que está viviendo la Unión.

Las resoluciones finales del Grupo Especial y ratificadas por el Órgano de Apelación nos reflejan parte de esa realidad, pues si bien concluyen que « $\underline{n o}$ se puede completar el análisis con respecto a la alegación de los Estados Unidos de que el sistema de administración aduanera de las Comunidades Europeas en su conjunto o en general no se aplica de manera uniforme, como prescribe el párrafo 3 a) del artículo X del GATT de 1994» ${ }^{145}$ por no estar legítimamente autorizados para ello, en lo que respecta a las clasificaciones arancelarias y a las ventas sucesivas si existió un pronunciamiento que demostró la falta de uniformidad en la aplicación de la normativa aduanera.

Esto nos lleva a concluir en la necesidad de unificar la normativa aduanera de gestión pues siendo la composición del Derecho aduanero en su mayor parte normas de carácter formal, es indispensable evitar distorsiones en su

\footnotetext{
${ }^{145}$ Informe del Órgano de Apelación. De Fecha: 13 de noviembre de 2006. Conclusiones b) V.
} 
aplicación, requiriéndose su regulación desde Bruselas, sin importar que su gestión siga a cargo del personal de los Estados miembros.

Una vez vistos de manera panorámica los aspectos más generales del Derecho Aduanero Comunitario Europeo, el siguiente Capítulo se dedica al estudio del núcleo de este trabajo como es el nacimiento de la deuda aduanera. 



\section{CAPÍTULO 2. EL NACIMIENTO DE LA DEUDA}

\section{ADUANERA.}

El artículo 4. 13 del CAM define la deuda aduanera cómo: «la obligación de una persona de pagar el importe de los Derechos de importación o exportación aplicables a mercancías específicas con arreglo a la legislación aduanera vigente». En términos de la doctrina española se identificaría con la obligación tributaría $^{146}$ más que con la deuda tributaría pues, como acertadamente refiere SÁNCHEZ GONZÁLEZ, I., “el término "deuda” se refiere tanto a la obligación de pago, como a la cuantía de dicha obligación expresada en la moneda apta para extinguirla. Las normas comunitarias se refieren a la acepción simple, al decir que deuda aduanera es "la obligación de una persona de pagar el importe de los Derechos de importación (deuda aduanera de importación) o de los Derechos de exportación (deuda aduanera de exportación)» ${ }^{147}$.

\footnotetext{
${ }^{146}$ CALVO ORTEGA, R. Curso de Derecho financiero I. Derecho Tributario parte general. $6^{\underline{a}}$ Ed. Madrid: Civitas, 2002, P. 161 «La obligación tributaria, debido a su carácter legal, nace de la realización de un hecho establecido en ley. Se trata de un hecho jurídico no sólo por su origen, sino también por sus efectos: una vez realizado el sujeto queda vinculado y debe efectuar una prestación obligatoria a favor de una Administración Pública como acreedor». MARTíN QUERALT, J. LOZANO SERRANO, C. CASADO OLLERO, G. TEJERIZO LÓPEZ, J. Curso de Derecho financiero y tributario. 20쯜. Ed. Madrid: Tecnos, 2009, P. 262-263 «Obligación tributaria es, por consiguiente, el vínculo jurídico del cual el sujeto pasivo debe ingresar al ente público la cuota del tributo. Esta es, a su vez, el objeto de dicha obligación de dar»

${ }^{147}$ SÁNCHEZ GONZÁLEZ, I. "La deuda aduanera”. Noticias/ C.E.E. 1991, № 79/80, P. 109
} 
Esa doble composición de la deuda tributaria, lleva a que en muchas ocasiones sea utilizada como sinónimo de la obligación tributaria ${ }^{148}$, siendo éste el caso de la deuda aduanera ${ }^{149}$, en cuya configuración queda claro que se refiere tan solo a la obligación de pago de los Derechos arancelarios ${ }^{150}$, mas no así a la cuota tributaria y demás elementos que conforman la deuda tributaria. En consecuencia, los supuestos que dan origen a la deuda aduanera son, en nuestra doctrina, los hechos imponibles de los tributos aduaneros ${ }^{151}$.

148 GONZÁLEZ GARCÍA, E. Y LEJEUNE, E. Derecho Tributario I. 2ª Ed. Salamanca: Plaza Universitaria Ediciones, 2000. P. 259 «pese a la especificación de sus distintos contenidos por el artículo 58 de la L.G.T., está usa en numerosos preceptos, y sin matices, el concepto de deuda tributaria cuando en realidad se está refiriendo a uno solo de sus componentes (la cuota tributaria), a la vez que se utiliza el concepto a veces como sinónimo de obligación tributaria y en ocasiones para referirse al contenido de la prestación de dar que constituye el objeto de la obligación tributaria material».

${ }^{149}$ PELECHA ZOZAYA, F. El Código aduanero comunitario y su aplicación en España. Ob. Cit. P. 139 "Como vemos, el concepto que de deuda aduanera se deriva de lo establecido en el artículo cuarto del CA no es muy feliz que digamos, toda vez que configura la deuda aduanera como una deuda tributaria; deuda tributaria en la que no se integran, por lo demás, las cantidades a pagar por la realización del hecho imponible a tributos que no son los Derechos del ACC ni las exacciones de efecto equivalente a los mismos ni, en fin, las exacciones adoptadas en el marco de la PAC, pero que son tributos en los que la entrada de mercancías en el territorio constituye un hecho imponible (caso del IVA, por ejemplo)"

150 DIRECCIÓN GENERAL DE ADUANAS E IMPUESTOS ESPECIALES. "La deuda aduanera". Aduanas informa sobre Comunidades Europeas. № 31 (mayo - junio 1989) P.4 «En la normativa comunitaria, la deuda aduanera queda limitada, pues a la obligación de pagar el importe de los Derechos de importación y de exportación». Entendiendo por Derechos a la importación de conformidad lo establece el artículo 4.15 «los Derechos de aduana que deben de pagarse por la importación de mercancías»

151 DIRECCIÓN GENERAL DE ADUANAS E IMPUESTOS ESPECIALES. "La deuda aduanera". Aduanas informa sobre Comunidades Europeas. № 31 (mayo - junio 1989) P.4 «A la hora de determinarlos hechos o situaciones que dan origen a la deuda aduanera, el Derecho 
Más allá del eterno debate en torno a la naturaleza jurídico-tributaria de los Derechos arancelarios, en el caso que nos ocupa resulta inviable generalizar una postura en cuanto a su naturaleza jurídico tributaria, ya que nos encontramos ante una pluralidad de supuestos de muy distinta naturaleza ${ }^{152}$. El CA contempla ocho supuestos que dan origen a la deuda aduanera a la importación ${ }^{153}$, mientras que el Código aduanero modernizado contempla

Comunitario una vez más pone de manifiesto su carácter eminentemente práctico y lejos de discusiones filosófico - jurídicas, que posiblemente hubieran llevado a doce países a debates interminables, elude dar una definición de hecho imponible y se limita a enumerar supuestos que dan lugar al nacimiento de la deuda aduanera». PELECHA ZOZAYA, F. El Código aduanero comunitario y su aplicación en España. Ob. Cit. P.40-41 «El legislador comunitario optó por no entrar en disquisiciones sobre lo que es el hecho imponible de los Derechos del $A A C$, y sí regular, en cambio, el cuándo nace la deuda aduanera, con lo que en gran parte está condicionando el concepto nacional de hecho imponible, puesto que aquélla - la deuda aduanera- no puede nacer si previamente no se ha realizado éste. En este sentido, ya la Directiva (CEE) del Consejo 79/623/CEE, de 25 de junio, y, posteriormente, el Reglamento (CEE) del Consejo 2144/1987, de 3 de febrero - en unos términos que luego han pasado a los arts. 189 a 242 del CA y a los arts. 857 a 867 de su RA-, determinaron cuándo surge la deuda aduanera, con lo que, indirectamente, estaban determinando qué hechos, por lo menos, debían ser considerados como hecho imponible de los Derechos del AAC».

${ }^{152}$ MÁRQUEZ Y MÁRQUEZ, A. Renta de Aduanas. 1aㅡ Ed. Madrid: EDERSA, 1979, P.66 «Esta concepción es de aplicación al hecho imponible aduanero de carácter complejo ya que supone la presencia de una multiplicidad de hechos reunidos de tal manera que constituye una unidad teleológica objetiva. En efecto, el paso de la línea aduanera, el destino a consumo, la nacionalización o la entrada de la mercancía forman parte de ese conjunto de hechos, de fases temporales, de actuaciones previas de diversa naturaleza que dan carácter complejo al hecho imponible aduanero de la importación».

${ }^{153}$ Despacho a Libre práctica "Art. 201.1 a)»; Inclusión de la mercancía a un régimen de importación temporal «Art. 201.1 b)»; Introducción irregular en el territorio aduanero de la Comunidad de una mercancía sujeta a Derechos de importación «Art. 202.1 a)»; Introducción irregular en el resto del territorio aduanero de la Comunidad de una mercancía sujeta a Derechos de importación, que se encuentre en una zona franca o depósito franco. "Art. 202.1 b)»; Sustracción de la vigilancia aduanera de una mercancía sujeta a Derechos de importación. 
cinco $^{154}$ supuestos agrupados en dos categorías: "Despacho a libre práctica e importación temporal” y “Deuda aduanera nacida por incumplimiento”.

Esta última clasificación parece parcialmente acertada, debiendo de completarse con una tercera categoría correspondiente a la importación irregular que no en todos los casos corresponde a una omisión de trámite, sino que nace de una naturaleza distinta como es la "Sustracción de la vigilancia aduanera de una mercancía sujeta a Derechos de importación”. De forma que, a nuestro parecer, debería agruparse de la siguiente manera:

"Art. 203. 1»; El incumplimiento de cualquiera de las obligaciones a que quede sujeta una mercancía sometida a Derechos de importación como consecuencia de su estancia en depósito temporal o de la utilización del régimen aduanero en el que se encuentre. "Art. 204. 1 a)»; La inobservancia de las condiciones señaladas para la concesión de tal régimen o para la concesión de un Derecho de importación reducido o nulo para la autorización de la mercancía para fines especiales. "Art. 204. 1 b)»; El consumo o la utilización, en la zona franca o en un depósito franco, en condiciones distintas de las previstas por la normativa vigente, de una mercancía sujeta a Derechos de importación. «Art. 205. 1».

${ }^{154}$ La reducción de ocho a cinco supuestos generadores de la deuda aduanera no significa la desaparición de ninguno de ellos, pues tan solo se agruparon en el apartado 1. A) del artículo 46 del CAM, los supuestos previstos en los artículos 202 y 203 del Código aduanero de 1992. 


\begin{tabular}{|c|c|}
\hline \multirow{2}{*}{ Regular } & Despacho a Libre práctica \\
\hline & Inclusión de la mercancía a un régimen de importación temporal \\
\hline \multirow{3}{*}{ Irregular } & $\begin{array}{l}\text { Introducción irregular en el territorio aduanero de la Comunidad de una } \\
\text { mercancía sujeta a Derechos de importación }\end{array}$ \\
\hline & $\begin{array}{l}\text { Introducción irregular en el resto del territorio aduanero de la } \\
\text { Comunidad de una mercancía sujeta a Derechos de importación, que se } \\
\text { encuentre en una zona franca o depósito franco. }\end{array}$ \\
\hline & $\begin{array}{l}\text { Sustracción de la vigilancia aduanera de una mercancía sujeta a } \\
\text { Derechos de importación. }\end{array}$ \\
\hline \multirow{3}{*}{ Por incumplimiento } & $\begin{array}{l}\text { El incumplimiento de cualquiera de las obligaciones a que quede sujeta } \\
\text { una mercancía sometida a Derechos de importación como } \\
\text { consecuencia de su estancia en depósito temporal o de la utilización del } \\
\text { régimen aduanero en el que se encuentre. }\end{array}$ \\
\hline & $\begin{array}{l}\text { La inobservancia de las condiciones señaladas para la concesión de tal } \\
\text { régimen o para la concesión de un Derecho de importación reducido o } \\
\text { nulo para la autorización de la mercancía para fines especiales }\end{array}$ \\
\hline & $\begin{array}{l}\text { El consumo o la utilización, en la zona franca o en un depósito franco, } \\
\text { en condiciones distintas de las previstas por la normativa vigente, de } \\
\text { una mercancía sujeta a Derechos de importación. }\end{array}$ \\
\hline
\end{tabular}


Independiente de la clasificación anterior que lista los "hechos imponibles específicos" que dan surgimiento a la deuda aduanera, la jurisprudencia reiterada del TJCE así como algunas consideraciones de la propia normativa ${ }^{155}$, ha establecido "la Importación en la Comunidad y la subsiguiente introducción de la mercancía en el circuito económico de la Comunidad”156, como el supuesto de hecho generador de los Derechos arancelarios a la importación. Es decir, el elemento objetivo o material del tributo que a la vez se constituye en el "hecho imponible genérico"157 en el que confluyen la totalidad

\footnotetext{
${ }^{155}$ Ejemplos:
}

Reglamento (CE) N $N^{\circ}$ 82/97 del Parlamento Europeo y del Consejo de 19 de diciembre de 1996 que modifica el Reglamento (CEE) $n^{\circ}$ 2913/92 por el que se aprueba el Código aduanero comunitario «3) Considerando que se debe garantizar en todos los casos que las mercancías obtenidas a partir de mercancías no comunitarias incluidas en un régimen suspensivo no entren en el circuito económico de la Comunidad sin pagar Derechos a la importación,...».

Reglamento (CE) n 3665/93 de la Comisión de 21 de diciembre de 1993 por el que se modifica el Reglamento (CEE) n²454/93 por el que se fijan determinadas disposiciones de aplicación del Reglamento (CEE) n² 2913/92 del Consejo por el que se establece el Código aduanero comunitario. "Considerando que se ha puesto de manifiesto que los Estados miembros aplican reglas divergentes relativas a la situación aduanera de las mercancías abandonadas en beneficio del Tesoro Público o decomisadas o confiscadas por las autoridades competentes; que mientras dichas mercancías no sean despachadas a libre práctica, una deuda aduanera sigue siendo susceptible de nacer al respecto; que conviene, por lo tanto, dictar disposiciones comunitarias con el fin de garantizar que las mercancías no entren en el circuito económico de la Comunidad sin pagar los Derechos a la importación»;

156 SENTENCIA DEL TRIBUNAL DE JUSTICIA (Sala Tercera) de 29 de abril de 2010, En el asunto C-230/08, Dansk Transport og Logistiky Skatteministeriet. Apartado 91. Ob. Cit

157 SENTENCIA DEL TRIBUNAL DE JUSTICIA (Sala Tercera) de 29 de abril de 2010, En el asunto C-230/08, Dansk Transport og Logistiky Skatteministeriet. Apartado 91. "Además, de la jurisprudencia del Tribunal de Justicia relativa a la aplicabilidad de la Sexta Directiva a la 
de supuestos específicos que generan la deuda aduanera, aun cuando este supuesto genérico no viene expresamente contemplado en la legislación positiva como hecho generador de la deuda aduanera. Esto hace necesario estudiar los Derechos arancelarios de acorde a su naturaleza genérica y posteriormente con relación a cada uno de sus hechos específicos.

importación ilegal de estupefacientes, resulta que, en esos casos, el hecho imponible y la exigibilidad de los Derechos de aduana y del impuesto sobre el valor añadido son esencialmente los mismos. En efecto, ambos regímenes poseen características esenciales análogas, por cuanto tienen su origen en la importación en la Comunidad y en la subsiguiente introducción de las mercancías en el circuito económico de los Estados miembros (véanse, en este sentido, las sentencias de 28 de febrero de 1984, Einberger, 294/82, Rec. p. 1177, apartado 18, así como de 6 de diciembre de 1990, Witzemann, C-343/89, Rec. p. I-4477, apartado 18)». 



\subsection{El hecho imponible genérico del nacimiento de la}

\section{deuda aduanera}

Aun cuando pareciera redundante hablar de importación e incorporación de la mercancía en el circuito económico de la Comunidad, se trata de hechos distintos pues “importación”, en el sentido que lo interpreta el TJCE, se traduce en la simple introducción de la mercancía en el territorio comunitario, sin que necesariamente produzca el nacimiento de la obligación aduanera. No dista mucho de la definición dada por la Organización Mundial de Aduanas que define en su glosario de términos aduaneros internacionales la importación como «el acto de introducir o de actuar para que se introduzca en un territorio aduanero cualquier mercancía» ${ }^{158}$. Por otra parte, la incorporación al circuito económico va más allá, como veremos a continuación.

Muy a pesar de que las instituciones comunitarias se refieren frecuentemente al "circuito económico de la Comunidad"159 encontramos dicho término indefinido por parte de la jurisprudencia y de la propia legislación comunitaria. Todo haría aparentar que se trata de un concepto económico universalmente aceptado y que por lo tanto no requeriría mayores comentarios, sin embargo, resulta todo lo contrario pues no encontramos referencias a dicho término en la doctrina comunitaria.

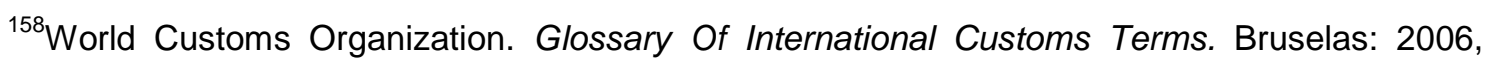
P.16 «Importation: The act of bringing or causing any goods to be brought into a Customs territory».

${ }^{159}$ Citado en por lo menos 67 normas y jurisprudencias desde 1976 a la fecha.
} 
El problema que se plantea en este caso va más allá de lo conceptual pues, la indeterminación de la expresión "circuito económico de la Comunidad" en el Derecho positivo comunitario crea una incertidumbre jurídica al ser el factor determinante para el nacimiento de la deuda aduanera. ¿En qué momento entenderemos que se tiene por incorporada la mercancía al circuito económico de la Comunidad, si no sabemos a ciencia cierta qué es el circuito económico y mucho menos sus elementos?

El término "circuito económico" hace alusión a la actividad económica (transacciones de bienes y servicios) que se realiza en un país o economía determinada $^{160}$. En el caso que nos ocupa, esa delimitación espacial del

\footnotetext{
${ }^{160}$ ANDERSEN, A. Diccionario de economía y negocios. Madrid: Espasa Siglo XXI, 1999. P.91 - 92 «Transacciones de bienes y servicios que se producen en la economía de un país, de forma que relacionan entre sí al sector productivo y a las economías domésticas y entre los que se establece un flujo económico real y otro monetario. Las economías domésticas proporcionan a las empresas el capital y la mano de obra necesarios para que produzcan los bienes y servicios que demandan las primeras, de forma que se cierra el ciclo real. Por otro lado, las empresas pagan, por los factores de producción, salarios y otras rentas a las economías domésticas que éstas emplean para el consumo, con lo que cierra también el flujo monetario.
} Esquema que se complica con la intervención de otros dos factores con funciones específicas, el sector público y el exterior, y que se interaccionan con el resto». GRECO, O. Diccionario de Economía. 3를 Ed. Buenos Aires Argentina: Valleta ediciones, 2006. P.126. «Flujos permanentes entre familias y empresas. En realidad constituyen movimientos de intercambios que se producen entre los diferentes agentes económicos. Los circuitos son complejos, ya que las empresas almacenan e invierten y las familias ahorran y no gastan la totalidad de sus ingresos inmediatamente». LEON C. P. y MARCONI SALVADOR, La contabilidad nacional: Teoría y métodos. 3를. Ed. QUITO: Ediciones ABYA-YALA, 1999, P. 25 Y 26. «Una forma- la más simplede representación del circuito económico es la que considera dos tipos de sujetos: Los capitalistas - empresarios y los trabajadores - consumidores; los primeros, utilizando la fuerza de trabajo proporcionada por los trabajadores, producen bienes y servicios destinados a la venta en el mercado. La clase de los trabajadores-consumidores está formada por quienes "venden" su fuerza de trabajo a cambio de un salario con el que adquieren bienes y servicios. 
circuito económico es el "mercado interior"161, que es el espacio físico ${ }^{162}$ en el que se desarrolla el intercambio de bienes, servicios y capital entre los distintos

Entre estos dos agentes se desarrollan un doble intercambio de medios de pago y de bienes; es decir, dos tipos de circuito estrechamente relacionados. El primero - el de los medios de pago- se manifiesta en un flujo de sueldos y salarios que tienen origen en la empresa y termina en los trabajadores, y en un flujo de sentido contrario, que representa el pago por los bienes que los trabajadores - consumidores compran a las empresas. El segundo circuito- el de los bienes y servicios reales- puede ser representado también mediante dos flujos: uno constituido por los servicios (fuerza de trabajo) prestados por los trabajadores, y otro constituido por los bienes finales (mercancías que las empresas ofrecen en el mercado a los consumidores). .http://www.economia48.com/spa/d/circuito-economico/circuito-

economico.htm "Circuito económico" (En inglés: economic circuit) Transacciones de bienes y servicios que se producen en la economía de un país, de forma que relacionan entre sí al sector productivo y a las economías domésticas y entre los que se establece un flujo económico real y otro monetario. Las economías domésticas proporcionan a las empresas el capital y la mano de obra necesarios para que produzcan los bienes y servicios que demandan las primeras, de forma que se cierra el ciclo real. Por otro lado, las empresas pagan, por los factores de producción, salarios y otras rentas a las economías domésticas que éstas emplean para el consumo, con lo que se cierra también el flujo monetario. Este esquema se complica con la intervención de otros dos sectores con funciones específicas, el sector público y el exterior, y que interaccionan con el resto».

161 Definiciones: Art. 26. 2 TFUE «El mercado interior implicará un espacio sin fronteras interiores, en el que la libre circulación de mercancías, personas, servicios y capitales estará garantizada de acuerdo con las disposiciones de los Tratados".STJCE defecha05 de mayo de 1982, asunto C-15/81, Caso: Shul, apartado 33, «(...) the concept of a common market as defined by the court in a consistent line of decisions involves the elimination of all obstacles to intra-community trade in order to merge the national markets into a single market bringing about conditions as close as possible to those of a genuine internal market.lt is important that not only commerce as such but also private persons who happen to be conducting an economic transaction across national frontiers should be able to enjoy the benefits of that market». LÓPEZ ESCUDERO, M. "El mercado interior: cuestiones generales". En: LÓPEZ ESCUDERO, M. MARTíN Y PÉREZ DE NANCLARES, J. y OTROS. Derecho comunitario material. Ob. Cit. P.29 «El mercado interior se identifica, por tanto, con un espacio económico unificado sin fronteras interiores y con la libertad de circulación de los factores productivos en condiciones de competencia no falseada. En definitiva, la circulación de mercancías, personas, servicios y capitales entre los Estados miembros debe de realizarse en condiciones similares a las 
actores del circuito (consumidores, productores, vendedores), al amparo de las cuatro libertades fundamentales que consagra el mercado interior: libre circulación de personas, bienes, capitales y servicios ${ }^{163}$.

De lo anterior se deduce que "la entrada de la mercancía al circuito económico de la Comunidad", equivale a que la mercancía importada pueda ser objeto de comercialización o consumo en el mercado interior europeo, como lo deja ver la sentencia del TJCE de fecha 29 de abril de 2010, caso: C-230/08, en su considerando $63^{164}$, y que nos ratifica de manera indirecta el artículo 129.1 del

existentes en un mercado nacional»». MATTERA, A. El mercado único europeo sus reglas de funcionamiento. Ob. Cit. P. 42. Define el mercado interior como: «un espacio económico común a los Estados que componen la Comunidad, en el marco del cual los ciudadanos y los agentes económicos (ya se trate de personas físicas o jurídicas) deben poder actuar libremente, gozando de los Derechos que les reconocen las reglas previstas por el propio Tratado, o establecidas al amparo de las disposiciones de éste, relativas a las cuatro libertades fundamentales de la Comunidad: la libre circulación de mercancías, personas, servicios y capitales. (....) Dichas reglas pretenden, por otra parte, el desarrollo de políticas comunes y de normas armonizadas en los distintos sectores de la vida económica con objeto de completar los resultados obtenidos al amparo de las disposiciones anteriormente mencionadas y de conseguir, así, una liberalización de los intercambios, en el seno de ese espacio económico común, comparable a la que rigen en el territorio nacional».

${ }^{162}$ Resulta necesario el puntualizar que al referirnos al mercado interior en su carácter de espacio físico, no significa que le neguemos sus otras características, pues basta con remitirnos a la cita anterior para verificar de la voz de diversos autores que el mercado único implica mucho más que un espacio físico.

${ }^{163}$ Ver. Diagrama Anexo 1.

${ }^{164}$ Sentencia del TJCE de fecha 29 de abril de 2010, caso: C-230/08, asunto: Dansk Transport og Logistiky Skatteministeriet. Aparatado 63, «A este respecto, procede señalar que el artículo 233, párrafo primero, letra d), del Código aduanero, por un lado, no hace referencia alguna a una eventual transmisión de la propiedad de las mercancías y, por otro lado, se refiere exclusivamente a la retirada definitiva del poder de disposición del propietario inicial y al hecho de evitar la comercialización en el circuito económico de la Comunidad sin pagar impuestos por 
Código aduanero modernizado. Éste al referirse al ámbito de aplicación del despacho a libre práctica refiere que «Las mercancías no comunitarias destinadas a ser introducidas en el mercado comunitario o destinadas a utilización o consumo privados dentro de la Comunidad se incluirán en el régimen de despacho a libre práctica». Por consiguiente y bajo esta perspectiva, la entrada de una mercancía extracomunitaria en el territorio aduanero de la Comunidad, junto con la factibilidad de comercialización o consumo de la mercancía extracomunitaria en el citado territorio, es el objeto material del supuesto.

Resulta evidente que queda superada la teoría propuesta por Giannini ${ }^{165}$, el cual atribuye el nacimiento de la deuda aduanera al paso de la línea aduanera, y nos acercamos más a la teoría propuesta por Jarach, Ferlazzo, Basaldúa y Pelecha para los cuales el hecho imponible de los Derechos arancelarios consiste en la introducción de la mercancía a fin de destinarla a consumo en el territorio aduanero ${ }^{166}$.

dichas mercancías. Pues bien, puesto que la destrucción de dichas mercancías bajo control estatal impide definitivamente la entrada de las mismas en el circuito económico, no es necesario saber si el Estado adquiere la propiedad de las mercancías intervenidas».

165 GIANNINI, A.D. Instituciones de Derecho Tributario. Traducido por SAINZ DE BUJANDA, F. $1^{\underline{a}}$ Ed. Madrid: Editorial de Derecho financiero, 1957, P. 523 -524

${ }^{166}$ BASALDUA, R.X. "Gravámenes al comercio exterior". En: INSTITUTO COLOMBIANO DE DERECHO TRIBUTARIO. Memorias / XXX Jornadas Colombianas de Derecho Tributario, Cartagena de Indias, 16, 17 Y 18 de Febrero de 2006. 1르. Ed. Bogotá: Instituto Colombiano de Derecho Tributario, 2006. P. 23 y 24. «En las legislaciones modernas, se distingue entre las importaciones y exportaciones tradicionales, que suponían el acceso a los respectivos mercados, de otras formas o modalidades de importar o exportar que no están sujetas al 
Esto no se debe de confundir con la teoría defendida por Cutrera, en la que identifican el hecho imponible aduanero en "la declaración de destino a consumo"167 pues, en primer lugar, en el caso que nos ocupa no es obligado

arancel aduanero, por ser transitorias o implicar únicamente el traslado a través del territorio aduanero de que se trate o el almacenamiento de las mercaderías. Por eso, en tales legislaciones se precisa, generalmente, que la introducción y el egreso relevantes a los efectos de la aplicación de los Derechos aduaneros son la importación y la exportación para consumo, es decir aquellas que autorizan en forma definitiva - sin sujeción a plazo alguno- la permanencia de las mercaderías en el territorio aduanero de que se trate. Este ingreso sine die posibilita su utilización económica irrestricta ("libre practica"), por lo que se dice la mercadería ha ingresado a consumo de plaza o a la circulación económica interna». FERLAZZO NATOLI. "El hecho imponible". Traducido por: CHAMORRO Y ZARZA, J.A. En: AMATUCCI.A. Tratado de Derecho tributario. Tomo II. 1aㅡ Ed. Bogotá - Colombia: Temis, 2001, p. 86. «Condición primaria del inicio del hecho imponible es el destino de la mercancía a consumo". JARACH, D. EL hecho imponible. 3" Ed. Ob. Cit. p. 59 «En el impuesto aduanero y en el impuesto interno al consumo, el hecho jurídico que da nacimiento al tributo no es la existencia de una mercadería, sino un acto de la vida económica, el de la introducción de una mercadería dentro de la frontera aduanera para destinarla al mercado interno o de la introducción en el mercado libre de una mercadería de consumo». PELECHA ZOZAYA, F. Fiscalidad sobre el Comercio exterior: el Derecho aduanero tributario. $1^{\text {a }}$ Ed. Madrid: Marcial Pons, 2009, P. 34 «Podemos considerar como "hecho imponible" de los Derechos del AAC la entrada de mercancías no comunitarias en el territorio aduanero de la Comunidad, normalmente para ser despachadas a libre práctica».

167 Ver al respecto CLAVIJO HERNÁNDEZ, F. "impuestos aduaneros". En: FERREIRO LAPATZA, J.F. et al. Curso de Derecho tributario parte especial: sistema tributario. Los tributos en particular. 18 ${ }^{\mathrm{a}}$ Ed. Madrid: Marcial Pons, 2002. P 755 -756. CORTÉS DOMíNGUEZ, M. "Introducción al Derecho aduanero". Aduanas, № 166 (Noviembre 1967) P. 3 - 9. CUTRERA, A. Principi di diritto e politica Doganale. 1aㅡ. Ed. Padova: CEDAM, 1941. P. 5 - 7. pie de página 2 «ll passaggio della línea doganale non determina, a favore dello Stato, il diritto subbiettivo all'imposta, ma stabilisce, a favore di esso, una semplice pretesa. Una volta varcata la linea doganale le merci estere sono sottoposte al potere di finanza dello Stato, il quale é autorizzato a prendere tutte le misure e tutte le cautele attead impedire la evasione del tributo. II diritto dello Stato allimposta, da parte dello Stato, si appeggia sulla determinazione del propietario della merce di destinarla al consumo dello Stato nonché sull'adempimiento delle obbligazioni accessorie e preliminari al pagamento (presentazione della dichiarazione e visita della merce). 
que exista una declaración, ya que no todos los supuestos generadores de deuda aduanera nacen de una declaración o la fijación de un destino en específico. Y, en segundo lugar, la declaración constituye una obligación de carácter formal que por sí misma no es reveladora de capacidad contributiva y su realización no siempre trae aparejado el nacimiento de la obligación tributaria $^{168}$

Por otra parte, hay que diferenciar la factibilidad de comercialización o consumo en el territorio comunitario del despacho a consumo. En el primero de los casos se refiere a la posibilidad fáctica y no siempre legal, de que la

Finché la merce non é stata dichiarata e non é stata visitata non sorge nello Stato alcun diritto all'imposta.

In altri termini el passagio della linea doganale nom stabilisce un diritto che lo Stato possa in un modo qualsiasi far valere, perché se cosí fosse si avrebbe un diritto sfortino di azione. Infantti contro chi lo Stato potrobbe farla valere quest'azione?

Il passaggio della linea doganale determina nello Stato la pretesa all'imposta nel senso che da questo momento la merce diventa oggetto del potere diritenzione, potere che lo Stato fa valere, non soltano ai fini del soddisfacimento dell'imposta, ma anche prima che sia nato un debito d'imposta, ma anche prima che sia nato un debito d'imposta, nonché per le merci per le quali un debito d'imposta forse non sorgerá mai».

168 AGULLÓ AGÜERO, A. La renta de Aduanas: configuración técnico jurídica y aspectos penales. 1' Ed. Madrid: IEF, 1978, P. 42 «La declaración aduanera por otra parte no es presupuesto de hecho de ninguna obligación, sino contenido de una obligación impuesta por la Ley a fin de proporcionar los datos que la administración exige. Es un acto debido que no puede tener como efecto la constitución de una obligación tributaria». CLAVIJO HERNÁNDEZ, F. "Impuestos aduaneros". Ob. Cit. P. 755 - 756. GARRE, F. "Importación, mercancía, territorio". En: GARRE,F. MARQUEZ, A. MUÑOZ, F. VICENTE, B. SANCHEZ, I. Estudios aduaneros. 1르 Ed. Madrid: IEF, 1974, P. 164 «La declaración no es el presupuesto de hecho, es una obligación impuesta por la ley a fin de proporcionar los datos que la administración le exige. La declaración aduanera es un acto que ordena la Ley, un acto debido y no puede tener como efecto la constitución de una obligación tributaria». 
mercancía pueda ser objeto de cualquier tipo de transacciones comerciales tales como la venta, el intercambio, etc. $\mathrm{O}$ bien que esta pueda ser utilizada 0 consumida en el territorio aduanero comunitario. En tanto el despacho a consumo, se refiere a la incorporación de las mercancías al circuito económico de manera legal, habiendo cubierto la totalidad de sus obligaciones formales y tributarias a fin de que pueda ser libremente destinada a cualquiera de las operaciones antes descritas $^{169}$.

${ }^{169}$ GONZÁLEZ GRAJERA, F. "Novedades en el procedimiento de gestión aduanera”. Aduanas. № 354 (1986). P. 59 «El despacho a consumo por su parte supone, no sólo el cumplimiento de las formalidades aduaneras y el pago de los correspondientes Derechos de importación, sino también el pago de los restantes impuestos indirectos (IVA, II.EE) aplicables de modo que la mercancía pueda ser "consumida" en el mercado interno y se incorpore a la corriente económica nacional en las mismas condiciones que el resto de las mercancías». WORLD CUSTOMS ORGANIZATION. Glossary Of International Customs Terms. Brussels, 2006. P.4 « The Customs procedure which provides that imported goods enter into free circulation in the Customs territory upon the payment of any import duties and taxes chargeable and the accomplishment of all the necessary Customs formalities" 


\subsection{Naturaleza jurídico-tributaria de los Derechos arancelarios.}

\subsubsection{Introducción}

La naturaleza jurídica tributaria de los Derechos arancelarios ha sido durante muchos años el centro del debate doctrinal de la imposición al comercio exterior. Las posturas han sido por demás variadas e inclusive contradictorias entre sí, desde aquellas que les niegan la naturaleza de tributaria a los Derechos arancelarios, hasta aquellas que los ubican en los más distintos tipos de tributos. Por lo que ante tal controversia y la diversidad de supuestos generadores de deuda aduanera que contempla el Código Aduanero, se hace necesario el estudio individualizado de la naturaleza jurídico-tributaria de cada uno de los supuestos. Iniciando como es lógico por el supuesto genérico en estudio.

En algunos reglamentos, directivas y sentencias comunitarias, se declara como fundamento de la norma aduanera "el deber de garantizar que las mercancías extracomunitarias no ingresen al territorio comunitario sin haber pagado los Derechos arancelarios correspondientes" ${ }^{\text {170 }}$, lo que nos podría llevar a pensar que la normativa aduanera comunitaria estuviese de acorde a la ya comentada tesis de LABAND, en la que se consideran los Derechos arancelarios como una carga real, que tiene que pagar la mercancía como requisito previo a su incorporación. Sin embargo, como ha quedado demostrado en el capítulo

\footnotetext{
${ }^{170}$ Ver los ejemplos ya citados en el pie de página 33.
} 
anterior, existe un error de planteamiento, ya que si bien el pago es un requisito previo, la relación jurídica no es entre el Estado y la mercancía, sino entre el Estado y el obligado al pago que sería el importador y/o exportador, siendo la mercancía únicamente una garantía del pago ${ }^{171}$.

No obstante, este mismo planteamiento sirvió de base a Berliri para concebir los Derechos arancelarios como una "carga en sentido técnico jurídico", propuesta más sólida que la formulada por Laband y que le llevó a considerar en un primer momento los Derechos arancelarios como tasas, para posteriormente replantearse su hipótesis y ubicarlos bajo la figura de los gravámenes fiscales.

El primero de los planteamientos lo realiza BERLIRI en el volumen II de sus Principios de Derecho tributario, diciendo: «Puede suceder que según el ordenamiento jurídico de un determinado país en momento dado el impuesto aduanero no constituya un verdadero debido por el tránsito de la línea aduanera, sino una carga a la que viene sujeto dicho tránsito o, más exactamente, la nacionalización de las mercancías extranjeras; es decir, puede suceder, utilizando una terminología a nuestro juicio más correcta, que el gravamen aduanero no sea un impuesto, sino una tasa» ${ }^{172}$. Comentario en el

\footnotetext{
${ }^{171}$ Ver al respecto CORTÉS DOMíNGUEZ, M. "Introducción al Derecho aduanero". Aduanas, № 160, 1967 P. 9 -11. AGULLÓ AGÜERO, A. "La renta de aduanas: configuración jurídica y aspectos penales". Ob. Cit. P. 36 -37. CLAVIJO HERNÁNDEZ, F. "impuestos aduaneros". Ob. Cit. P.751-752

${ }^{172}$ BERLIRI, A. Principios de Derecho tributario, Volumen II. AMORÓS RICA, N. (Trad. y Prol.); GONZÁLEZ GARCÍA, E. (Trad. y Prol). Madrid: Editorial de Derecho Financiero, 1971, P. 174
} 
que ahonda a píe de página diciendo: «Así pues, no parece tan absurdo (aunque ello no obsta para investigar en cada caso si ha sido ésta la construcción adoptada por el legislador) que el deber de pagar el impuesto no constituya una obligación, sino una carga imprescindible para obtener el permiso de importación o de exportación de las mercancías o, mejor, para conseguir su nacionalización o desnaturalización ${ }^{173}$.

Esta construcción doctrinal que ubica los Derechos arancelarios como tasas por la prestación de un servicio es ampliamente rebatida por CORTÉS DOMíNGUEZ seguido por AGULLÓ AGÜERO y CLAVIJO HERNÁNDEZ, quienes argumentan su negativa en la ausencia de actividad del Estado en la realización del hecho imponible de los derechos arancelarios ${ }^{174}$, por lo que bajo esa perspectiva no podrían ser catalogados como tasas por prestación de servicios al incumplir el elemento esencial de la prestación de un servicio de forma directa e individualizada por parte de la administración pública ${ }^{175}$, esta

173 Ibidem

${ }^{174}$ Por su parte CORTÉS DOMíNGUEZ, M. "Introducción al Derecho aduanero". Aduanas, № 160 , ob. Cit. P.12 «cualquiera que sea la tesis que se sustente respecto a cuál sea el hecho imponible del impuesto aduanero, parece evidente que siempre se trata de una actividad del sujeto pasivo, sin que la administración colabore en la realización del hecho imponible, aunque intervenga de una manera directa y extensa controlando e inspeccionando la actuación en las operaciones aduaneras del contribuyente». En el mismo sentido y parafraseando a CORTÉS DOMÍNGUEZ se pronuncian: AGULLÓ AGÜERO, A. "La renta de aduanas: configuración jurídica y aspectos penales". Ob. Cit. P. 38 "cualquiera que sea el presupuesto de hecho elegido como base del mismo, nos encontraremos siempre con el presupuesto de hecho propio de un impuesto y no de una tasa". CLAVIJO HERNÁNDEZ, F. "impuestos aduaneros". Ob. Cit. P.753 cita textualmente a CORTÉS DOMÍNGUEZ.

${ }^{175}$ GIANNINI, A.D. Instituciones de Derecho Tributario. Ob. cit. P. 50 «la prestación pecuniaria debida a un ente público, en virtud de una norma legal y en la medida que en ésta se 
falta de contraprestación del Estado sirvió a BERLIRI para replantearse su teoría y negarle a los Derechos arancelarios el carácter de "tasas por prestación de un servicio"176.

Queda claro que la incorporación de una mercancía al circuito económico de la comunidad, no siempre implica la prestación de algún servicio directo e individualizado por parte de la Administración, máxime que no en todos los supuestos generadores de la deuda aduanera existe intervención de la autoridad, en tanto la incorporación de la mercancía al circuito económico no se da siempre por los medios legales correspondientes, originándose en algunas ocasiones la incorporación de la mercancía de manera irregular, y por lo tanto al margen de la intervención de la autoridad. Con relación a esta última posición cabe decir que si bien es cierto que en el supuesto genérico no existe una actividad directa del Estado que se refleje en la prestación de un servicio

establezca, por la realización de una actividad del propio ente que afecta de modo particular al obligado». P.7 «La tasa se caracteriza por tener «frente a la prestación del ciudadano una contraprestación del ente público. (...) La prestación del ciudadano no constituye el cumplimiento de una obligación, sino un hecho jurídico, libremente deseado por el contribuyente, mientras que la prestación de la Administración -que no es una verdadera obligación- nace de la ley y no de una manifestación de voluntad. Dicho de manera más clara hay una tasa cuando se está en presencia de una norma de este tipo; quien quiera tener Derecho a tal prestación tiene que pagar. Así, pues, el ente público está obligado a prestar tal servicio no porque lo haya deseado, sino porque se ha verificado un hecho - el pago de la tasa- que, por efecto de la ley, ha determinado el nacimiento en él de la obligación».

${ }^{176}$ BERLIRI, A. "La obligación tributaria aduanera". Aduanas. 272 -273. P. 7 al cuestionarse como debe de calificarse el Derecho de aduanas refiere "Evidentemente hay que excluir tanto la contribución, porque faltan todos los elementos, como la tasa, en cuanto al pago del Derecho de aduanas no confiere al contribuyente el Derecho a una prestación por parte de la administración pública». 
de forma directa a favor del contribuyente, esto no significa la inexistencia de actividad del Estado, pues está se refleja en la gestión y conservación del bien de dominio público que lo hace seguir siendo susceptible de uso y aprovechamiento, además de que en algún otro de los supuestos contemplados por el CA pudiera existir contraprestación directa por parte del Estado.

\subsubsection{Los derechos arancelarios en su naturaleza jurídica de tasas por utilización de bienes de dominio público}

Las consideraciones vertidas en párrafos anteriores nos lleva a plantearnos si los derechos arancelarios pudieran ser tasas por la utilización de un bien de dominio público dada la incorporación de la mercancía al circuito económico de la Comunidad, es decir por el uso y aprovechamiento del mercado interior europeo. En este sentido, aun cuando la jurisprudencia y la normativa hablan de la incorporación de la mercancía al circuito económico como hecho imponible, queda claro que esa incorporación no es otra cosa que la factibilidad de que la mercancía pueda ser sujeta a comercialización, uso o consumo en el mercado interior. Actividades que son una forma de utilización del mercado interior, pues se valen de la estructura y libertades creadas en el mercado interior para su realización, por lo que bajo este razonamiento, el elemento objetivo del gravamen sería el uso o aprovechamiento del mercado interior. 
Un primer problema que puede surgir, es que a pesar de que en el Derecho positivo de algunos Estados miembros, entre ellos España y Portugal, se contempla la utilización de un bien de dominio público como hecho generador de la tasa ${ }^{177}$, no es muy común en la doctrina de estos países hacer referencia a las tasas por utilización de bienes del dominio público, refiriéndose en la mayoría de las ocasiones tan sólo a las tasas que se pagan como contraprestación o con motivo de la prestación de un servicio público, sin que esto signifique su ausencia total en la doctrina. Esta ausencia parcial ha servido para que algunos autores como DE LA GARZA les nieguen a las tasas por utilización o aprovechamiento de bienes de dominio público el carácter de tasa, ubicando a tales prestaciones como un impuesto ${ }^{178}$, sin embargo algún sector

\footnotetext{
${ }^{177}$ Ley General Tributaria Española artículo 2.2 «a) Tasas son los tributos cuyo hecho imponible consiste en la utilización privativa o el aprovechamiento especial del dominio público, la prestación de servicios o la realización de actividades en régimen de Derecho público que se refieran, afecten o beneficien de modo particular al obligado tributario, cuando los servicios o actividades no sean de solicitud o recepción voluntaria para los obligados tributarios o no se presten o realicen por el sector privado. Se entenderá que los servicios se prestan o las actividades se realizan en régimen de Derecho público cuando se lleven a cabo mediante cualquiera de las formas previstas en la legislación administrativa para la gestión del servicio público y su titularidad corresponda a un ente público».
}

Léi Geral Tributaria Portuguesa artículo 4.2 "As taxas assentam na prestação concreta de um serviço público, na utilização de um bem do domínio público ou na remoção de um obstáculo jurídico ao comportamento dos particulares».

${ }^{178}$ DE LA GARZA, S.F. (Derecho Financiero Mexicano. 16 Ed. México: Porrúa, 1990, P. 338339) hace el señalamiento de la ausencia total en la doctrina española, de referencias o análisis de las tasas por utilización de bienes de dominio público, tomando como referencia a: SÁINZ DE BUJANDA, NARCISO AMORÓS, ADOLFO CARRETERO, FERREIRO LAPATZA, PÉREZ DE AYALA y GONZÁLEZ GARCÍA. Ausencia que lleva al autor a concluir : P. 341 «que independientemente del nombre de Derechos que le da el legislador, las contraprestaciones que se pagan al Estado por el uso o el aprovechamiento de bienes del dominio público no 
de la doctrina contemporánea ha retomado su estudio reconociéndole su carácter singular y distinto al impuesto ${ }^{179}$. La jurisprudencia del Tribunal Constitucional se ha ocupado del tema en su Sentencia $185 / 1995^{180}$, en la cual

tienen el carácter de una actividad del Estado, referida inmediata ni mediatamente, ni directa ni indirectamente, al obligado. Por consecuencia el tributo que se establece tiene el carácter de impuesto». Las conclusiones a las que llega el autor pueden ser ampliamente discutidas y rebasan el objeto de esta investigación.

179 Por otra parte habría que objetarse, que si bien es cierto en los autores que señala DE LA GARZA, y en la mayoría de la doctrina española no se comentan las tasas por utilización de un bien de dominio público ello no significa su ausencia total, muestra de ello son: MARTIN QUERALT, J. y OTROS. Curso de Derecho Financiero y Tributario. Ob. Cit. P. 89 - 90 «La utilización por un particular de los bienes que son de dominio público, o su aprovechamiento especial, requiere que los Entes públicos titulares de esos bienes demaniales concedan, con carácter previo, una autorización u otorguen una concesión. En consecuencia, si el particular quiere utilizar o aprovechar el dominio público tiene que obtener una autorización, pagando la oportuna tasa». LAGO MONTERO, J.M. Comentario a la Ley de Tasas y Precios públicos de la Comunidad de Castilla y León. 1aㅡ Ed. Madrid: Dykinson, S.L. 2005, P.117 “ Como anunciábamos en el comentario al art. 1 de esta L.T.P.P.M., para acometer adecuadamente la tarea de fijar criterios de cuantificación de las tasas es necesario tratar por separado, al menos, tres grandes grupos de tasas, exigibles por tres tipos de presupuestos de hecho: a) la utilización privativa o aprovechamiento especial del dominio público; b) la prestación o utilización de servicios públicos no esenciales; y c) la prestación o utilización de servicios públicos esenciales. Y ello porque la presencia del principio de capacidad económica en cada uno de estos tres grupos se aprecia de manera diferente. El grupo a) comprendería los supuestos de hecho especialmente aptos para el establecimiento de tasas, de cuantía a graduar primordialmente en función de la intensidad del uso privativo o especial verificado por cada sujeto pasivo, del valor del aprovechamiento a realizar, indicador claro de la riqueza=Derecho que afluye a su patrimonio».

${ }^{180}$ STC de 14de diciembre de 1995 (RTC 1995, 185) «Los bienes que componen el demanio son de titularidad de los Entes públicos territoriales y su utilización privativa o su aprovechamiento especial están supeditados a la obtención de una concesión o una autorización que corresponde otorgar exclusivamente a esos Entes. Existe, por tanto, una situación que puede considerarse de monopolio ya que si un particular quiere acceder a la utilización o al aprovechamiento citados para realizar cualquier actividad debe acudir forzosamente a los mismos. La única alternativa que le cabe al particular para eludir el pago del 
pone de manifiesto en primer lugar la obligatoriedad del pago de la tasa y en segundo lugar la contraprestación del Estado en forma de concesión o autorización para hacer uso del demanio.

A los efectos de esta investigación resulta más acorde la dualidad de la tasa que formula el Derecho positivo y la jurisprudencia es decir, la posibilidad de que éste tributo nazca indistintamente por la prestación de un servicio público, o por la utilización o aprovechamiento de un bien de dominio público. Ello suscita dos cuestiones: la primera es si el Mercado Único de la Comunidad europea es un bien de dominio público; la segunda es si la incorporación de la mercancía al circuito constituye un aprovechamiento especial.

Para ello debemos de partir del concepto de bienes de dominio público, en el que nuevamente existen diferencias sustanciales: un sector de la doctrina sostiene la relación de propiedad del Estado sobre los bienes de dominio público $^{181}$, en tanto otro sector doctrinal sostiene que un bien de dominio

precio público es la abstención de la realización de la actividad anudada a la utilización o aprovechamiento del demanio, pero ya hemos dicho que la abstención del consumo no equivale a libre voluntariedad en la solicitud».

${ }^{181}$ BERMEJO VERA, J. - GARCÉS, A. - GARCÍA ALVAREZ, G. - GIMENO, J.M. - OLIVÁN, J. TEJEDOR, J.C. - TENA.V. Derecho administrativo parte especial. 1a Ed. Madrid: Civitas, 1994, p. 307 «Otra postura doctrinal, mayoritaria en nuestro país y con un sólido respaldo en los textos legales vigentes, es continuadora de la tesis expuesta por M. HAURIOU. EI insigne jurista francés considera a los bienes de dominio público como aquellas propiedades administrativas afectadas a la utilidad pública y que, por consecuencia de esta afectación, resultan sometidas a un régimen especial de utilización y protección. Indudablemente el criterio de la afectación constituye el criterio definidor del dominio público con arreglo a estos principios. Para la opinión más destacada y mayoritaria de la doctrina española (GARCÍA DE ENTERRÍA y GARRIDO FALLA), el dominio público es una relación de propiedad que las diferentes Administraciones Públicas de base territorial tienen sobre determinados bienes, en 
público, no se refiere de manera exclusiva al Derecho de propiedad del Estado sobre un bien tangible y concreto, sino más bien al ejercicio de un poder soberano de regulación, administración y aprovechamiento tanto de bienes tangibles como intangibles ${ }^{182}$.

cuanto sometidos a un régimen jurídico exorbitante del Derecho civil». PARADA, R. Derecho Administrativo III Bienes públicos. Derecho urbanístico. 20를 Ed. Madrid: Marcial Pons, 2010, P. 53 «A nuestro juicio, y desde la recelosa perspectiva de que ninguna tesis resuelve satisfactoriamente todas las cuestiones, al menos la tesis dominio público como propiedad ha servido, aparte de otras utilidades, para establecer un régimen de protección y seguridad jurídica (Como el acceso a registros, acciones defensivas, deslinde, etc.) perfectamente encajables, aunque derogatorias por exorbitantes, en el concepto de propiedad; y sigue sirviendo para algo fundamental: para que los particulares puedan plantear "cuestiones de propiedad" ante tribunales civiles, cuando las suyas son desconocidas o invalidas so pretexto de su condición demanial que la Administración invoca; una garantía fundamental, difícil de imaginar si las Administraciones Públicas no fueran propietarias de los bienes de dominio público sino simples titulares de soberanía, funciones públicas o títulos de intervención contra las que resultan inimaginables acciones civiles en defensa de la propiedad privada».

${ }^{182}$ BANDEIRA DE MELLO, C.A. Curso de Derecho administrativo. LABRAÑA PARRA, V.E. (Trad.).1 Ed. México: Porrúa y UNAM, 2006, P. 773 «El conjunto de bienes públicos forma el "dominio público", que incluye tanto bienes inmuebles como muebles. Esta noción incluye las procedentes lecciones del brillante especialista en Derecho público, Rui Cirne Lima, según el cual la noción de dominio público es más extensa que la propiedad, pues en ella se incluyen bienes que no pertenecen al poder público; la marca específica de los que componen tal dominio es que participan de la actividad administrativa pública, estando, en consecuencia, bajo el signo de la relación de la administración, que domina y paraliza la propiedad pero que

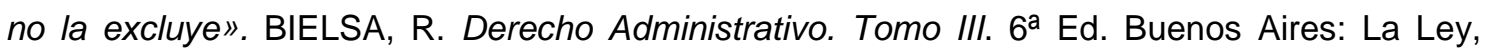
1964, P. 455 Nota pie de página 1 «Pero en nuestro sistema se ha establecido- de acuerdo con la división que hace el Código civil- una doble categoría de bienes: de dominio público y de dominio privado del Estado (Terry), siendo así que considerando al Estado como persona jurídica que es, no puede tener sino "un patrimonio", es decir, un conjunto de bienes que lo constituyen, aunque en razón de su utilidad -que es siempre pública-, sea ésta mediata o inmediata, siempre su único destinatario es la colectividad. Además no debe de olvidarse que el concepto de dominio no es aquí el de la Ley civil, entendiendo como "derecho de propiedad sobre cosas", es decir, derecho de propiedad sobre "bienes corporales", sino que en el 
concepto de dominio público compréndense un derecho o una atribución jurídica de uso sobre un conjunto de cosas que pueden ser usadas por todos, ya uti singuli (individualmente), ya uti universo (en su conjunto, pero en manera indirecta). El Estado en sentido lato: Nación, provincia y comuna) regla ese uso. La potestad de afectar o reglar el uso de los bienes públicos es de índole legislativa». MARIENHOFF, M.S. Tratado de Derecho administrativo. Tomo V. Dominio Público. 4aㅡ Ed. Buenos Aires: Abeledo-Perrot, 1998 P. 37 «puede afirmarse que, aparte de las "cosas" -objetos corporales-, no sólo los "Derechos" constituidos por servidumbres públicas integran el dominio público: también lo integran otros "Derechos", como asimismo ciertos "objetos inmateriales", que no son precisamente "Derechos". Vale decir que, además de las "cosas", pueden revestir calidad dominical los "bienes" en general». MARTíNEZ MORALES, R.I. Diccionarios jurídicos temáticos. Derecho administrativo. $2^{\mathrm{a}}$ Ed. México: Oxford University Press, 2000, P. 82 «Sector de los bienes del estado sobre los cuales éste ejerce una potestad soberana, conforme a las reglas del Derecho público, a efecto de regular su uso o aprovechamiento, y de esa manera asegurar su preservación o explotación racional». NAVA NEGRETE, A. QUIROZ ACOSTA, E. "Bienes de dominio público". En: INSTITUTO DE INVESTIGACIONES JURÍDICAS. Enciclopedia jurídica mexicana. Tomo I. 1aㅡ. Ed. México: Porrúa - UNAM, 2002, P.540 «El dominio público es un Derecho de gestión, de regulación, de vigilancia, pero no un Derecho de propiedad que implica los Derechos de gozar y disponer de las cosas casi en forma absoluta». OTTO MAYER. Derecho Administrativo Alemán. Tomo III Parte especial. El Derecho de las cosas públicas. HEREDIA, H. y KROTOSCHIN, E (Traductores). 1를 Ed. Buenos Aires: Editorial Depalma, 1951, P. 121 «la cosa representa por sí misma una parte de la administración pública; cuando, por ella, el Estado administra directamente y cuando el interés del servicio es demasiado importante y está ligado demasiado íntimamente al estado jurídico de la cosa, para dejarla expuesta a las vicisitudes de los actos del Derechos civil». En otros párrafos OTTO MAYER, al referirse a las "cosa públicas" manifiesta que: P. 114 «la existencia intacta y funcionamiento tranquilo forman parte del buen orden público; es lógico que la protección contra los trastornos que pudieran ocasionárseles, tome el nombre y el carácter de policía». Es en este rubro me parece por demás revelador de la posibilidad de intangibilidad de la cosa pública la cita que el autor hace de F. SHULTZ, el cual dice: P.115, cita a pie de página 21. "Aunque la policía no puede tener una posesión de Derecho privado, se le permitirá, sin embargo, designar como posesión al poder de hecho que la policía ejerce aquí sobre la cosa".VANESTRALEN, H. "bienes de titularidad pública: patrimoniales y de dominio público. Una aproximación al sistema español". Estudios SocioJurídicos. Bogotá, Colombia, № 6 (enero-junio de 2004), P. 218 «En Alemania el panorama de los bienes públicos es un poco más complicado. Se habla de cosas públicas, concepto que abarca un amplio espectro de objetos con algún tipo de contenido económico tanto corporales como incorporales, que están destinados a un fin público y por tal razón están protegidos por un estatus jurídico público, lo cual desplaza su condición normal de sometimiento a un régimen 
En la práctica se ha tenido la necesidad de regular ciertos bienes intangibles como bienes de dominio público incluyendo aquellos países en los que su doctrina mayoritaria identifica el dominio público con la propiedad, siendo ejemplo de ello la denominación del espacio radioeléctrico como bien de dominio público ${ }^{183}$. En consecuencia, resulta evidente que ha prevalecido el sector doctrinal que reconoce el carácter de bienes de dominio público a los bienes inmateriales, por lo que en este contexto podemos definir los bienes de dominio público como el bien mueble o inmueble, tangible o intangible, destinado al uso público, que representa por sí mismo una parte del Estado, quien ejerce sobre él un poder soberano de regulación, administración y/o aprovechamiento y que por su misma naturaleza se encuentra fuera del mercado y normado por el Derecho público, pues «su destino no permite que

privado. Sin embargo, es esencial la afectación -acto formal del Estado en el que se dispone su destinación a un fin público-, ya que pueden aparecer cosas destinadas a uso público, pero que no están afectadas, y por lo tanto, están sometidas al régimen privado. El estatus público se construye a partir de las nociones de poder jurídico absoluto, es decir, tiene que ser respetado por todo el mundo, y de Derechos relativos, los cuales establecen el deber de conducta de los terceros frente al titular del Derecho. La calificación pública proviene del legislador que llena su contenido del conjunto de Derechos y obligaciones del propietario y los terceros. Sin embargo, se presenta excepcionalmente la dualidad o doble estatus cuando se enfrentan los conceptos de propiedad y señorío (potestad del Estado) sobre un mismo bien, aunque bajo una sola titularidad pública».

${ }^{183}$ Verbigracia España. El artículo 43.1 de la Ley General de Comunicaciones (Ley 32/2003), establece que: «El espectro radioeléctrico es un bien de dominio público, cuya titularidad, gestión, planificación, administración y control corresponden al Estado». 
esté en poder de un particular que dispondría de él según sus intereses personales ${ }^{184}$.

Postura que convalida el Tribunal Constitucional Español en su STC 227/1988 de 29 de noviembre de 1988 en la que consideró que «la incorporación de un bien al dominio público supone no tanto una forma específica de apropiación por parte de los poderes públicos, sino una técnica dirigida primordialmente a excluir el bien afectado del trafico jurídico privado, protegiéndolo de esta exclusión mediante una serie de reglas exorbitantes de las que son comunes en dicho trafico iure privato ${ }^{185}$.

En concordancia con lo anterior es preciso analizar si el mercado de un país en general y, más específicamente, el mercado común, concuerda con los preceptos señalados con antelación, para determinar si se trata de un bien de dominio público ${ }^{186}$.

Definir el concepto "mercado" no es una tarea sencilla, basta con ver la definición que brinda el diccionario de la Real Academia Española ${ }^{187}$ o la

${ }^{184}$ OTTO MAYER. Derecho Administrativo Alemán. Tomo III Parte especial. El Derecho de las cosas públicas. Ob. Cit. P. 91

${ }^{185}$ España. Tribunal Constitucional (Pleno) [Internet]. Sentencia 227/1988, de 29 de noviembre de 1988 [consultado 05 de marzo de 2013]. Disponible en: http://www.boe.es/diario_boe/txt.php?id=BOE-T-1988-29199

${ }^{186}$ No está por demás acotar que la presente tesis no pretende ser un estudio económico, por lo que el tema del mercado se abordara desde la perspectiva netamente jurídica y en relación directa con el caso planteado.

187 REAL ACADEMIA ESPAÑOLA. "Mercado". En: Diccionario de la Lengua (En línea). http://buscon.rae.es/drael/SrvltConsulta?TIPO BUS=3\&LEMA=mercado

(Consultado 
enciclopedia británica ${ }^{188}$ para darnos cuenta de ello. En sus distintas acepciones identifica como mercado a muy diversos conceptos, cuyas

11/09/2015). «mercado. (Del lat. mercātus). 1. m. Contratación pública en lugar destinado al efecto y en días señalados. Aquí hay mercado los martes. 2. m. Sitio público destinado permanentemente, o en días señalados, para vender, comprar o permutar bienes o servicios. 3. $\mathrm{m}$. Concurrencia de gente en un mercado.El mercado se alborotó. 4. m. Conjunto de actividades realizadas libremente por los agentes económicos sin intervención del poder público. 5. m. Conjunto de operaciones comerciales que afectan a un determinado sector de bienes. 6. m. Plaza o país de especial importancia o significación en un orden comercial cualquiera. 7. m. Conjunto de consumidores capaces de comprar un producto o servicio. 8. m. Estado y evolución de la oferta y la demanda en un sector económico dado.

${ }^{188}$ ENCICLOPEDIA BRITANICA. "Market". En: Britannica Online Encyclopedia. http://www.britannica.com/EBchecked/topic/365647/market (Consultada 11/09/2015). «market, a means by which the exchange of goods and services takes place as a result of buyers and sellers being in contact with one another, either directly or through mediating agents or institutions. Markets in the most literal and immediate sense are places in which things are bought and sold. In the modern industrial system, however, the market is not a place; it has expanded to include the whole geographical area in which sellers compete with each other for customers. Alfred Marshall, whose Principles of Economics (first published in 1890) was for long an authority for English-speaking economists, based his definition of the market on that of the French economist A. Cournot: Economists understand by the term Market, not any particular market place in which things are bought and sold, but the whole of any region in which buyers and sellers are in such free intercourse with one another that the prices of the same goods tend to equality easily and quickly. To this Marshall added: The more nearly perfect a market is, the stronger is the tendency for the same price to be paid for the same thing at the same time in all parts of the market. The concept of the market as defined above has to do primarily with more or less standardized commodities, for example, wool or automobiles. The word market is also used in contexts such as the market for real estate or for old masters; and there is the "labour market," although a contract to work for a certain wage differs from a sale of goods. There is a connecting idea in all of these various usages-namely, the interplay of supply and demand. Most markets consist of groups of intermediaries between the first seller of a commodity and the final buyer. There are all kinds of intermediaries, from the brokers in the great produce exchanges down to the village grocer. They may be mere dealers with no equipment but a telephone, or they may provide storage and perform important services of grading, packaging, and so on. In general, the function of a market is to collect products from scattered sources and channel them to scattered outlets. From the point of view of the seller, dealers channel the 
diferencias resultan más que evidentes (espacio físico, actividad económica, población, consumidores, etc.); no obstante sus diferencias, cada uno de los conceptos con los que se identifica al mercado forman a su vez los elementos esenciales de una concepción más amplia de mercado. En el ámbito de la economía, se alude al mercado como un mecanismo o proceso por medio del cual se resuelven los tres problemas fundamentales de la economía: Qué producir, para quién producir, cómo producir ${ }^{189}$.

demand for his product; from the point of view of the buyer, they bring supplies within his reach. There are two main types of markets for products, in which the forces of supply and demand operate quite differently, with some overlapping and borderline cases. In the first, the producer offers his goods and takes whatever price they will command; in the second, the producer sets his price and sells as much as the market will take. In addition, along with the growth of trade in goods, there has been a proliferation of financial markets, including securities exchanges and money markets».

189 BEGG,D. FISCHER, S. DORNBUSCH, R. y FERNÁNDEZ DÍAZ, A. Economía. 8aㅡ. Ed. Madrid: Mc Graw Hill, 2006, P. 9 «Un mercado es un proceso por el que las decisiones de los hogares sobre los bienes que van a consumir, las decisiones de las empresas sobre lo que van a producir y cómo van a producirlo y las decisiones de los trabajadores sobre la cantidad que van a trabajar y para quién van a trabajar se concilian entre ellas por medio del ajuste de los precios". HÄBERLE, P. "Siete tesis para una teoría constitucional del mercado". Traducido del alemán por AZPITARTE SÁNCHEZ, M. Revista de Derecho constitucional europeo. № 5, Enero-Junio de 2006, 11-30. «El significado del mercado se desvela en un primer acercamiento con ayuda de las claves propias del lenguaje cotidiano: "por mercado ha de entenderse el intercambio producido entre la oferta y la demanda"; "el mercado es el espacio del intercambio, en el que se forman los precios con el cruce de la oferta y la demanda"; "el mercado es el proceso en el que la especial propiedad sobre los medios de producción, basada en la participación de los trabajadores (economía de mercado), dirige la producción para lograr de la mejor manera la satisfacción de las necesidades más urgentes de los consumidores"». SAMUELSON, P.A. y NORDHAUS, W.D. Economía. 13a Ed. Madrid: Mc Graw Hill, 1990, P. 47 «Un mercado es un mecanismo por medio del cual los compradores y los vendedores de un bien determinan conjuntamente su precio y su cantidad». 
Si nos constriñéramos a la concepción de mercado como espacio físico no existiría duda alguna en cuanto a su naturaleza demanial, pues el territorio como elemento esencial del Estado es por su propia naturaleza un bien de dominio público. No obstante, es evidente que no nos podemos centrar únicamente en el ámbito espacial, pues es tan sólo uno de los elementos que componen el mercado; en segundo lugar, de seguir esa teoría estaríamos afirmando que el elemento objetivo del hecho imponible de los derechos arancelarios es la entrada de la mercancía en el territorio aduanero, lo cual es erróneo, pues como hemos venido reiterando el hecho imponible de los derechos arancelarios es la entrada de la mercancía en el circuito económico de la Comunidad, que se identifica mayormente con aspectos más abstractos del mercado como la actividad económica y un poco menos con el aspecto físico espacial, pues la propia concepción de "Circuito económico" se refiere más a la actividad económica que se desarrolla en el Mercado interior que a la demarcación territorial en la que se desarrolla. Por lo que bajo esa idea la demanialidad del mercado estará dada en gran medida por la intervención del Estado en el proceso económico, pues como dijera BOB JESSOP «La "economía nacional" es solamente un espacio imaginado posible de la actividad económica. En consecuencia, en vez de buscar criterios objetivos para identificar los límites necesarios del espacio económico (o cualquier escala funcional o territorial), es más provechoso plantear este tema en términos de una constitución imaginaria (naturalización) de la economía. Al mismo tiempo, 
los modos sociales de regulación económica ayudan a constituir y naturalizar sus objetos en y a través de los mismos procesos de regulación ${ }^{190}$.

Según las formas de intervención del Estado en los mercados se pueden clasificar en tres categorías:

- Economía autoritaria: Es aquella en la que el Estado decide unilateralmente, e impone los mecanismos a seguir en el proceso ${ }^{191}$.

- Libre mercado: «Conjunto de actividades realizadas libremente por los agentes económicos sin intervención del poder público» ${ }^{192}$.

- Economía Mixta: Es el punto medio de las dos antes descritas, en la cual tanto el Estado como los particulares intervienen en el proceso ${ }^{193}$.

190 JESSOP, B. ¿Narrando el futuro de la economía nacional y el estado nacional? Puntos a considerar acerca del replanteo de la regulación y la re-invención de la gobernancia. Documentos y Aportes en Administración Pública y Gestión Estatal. 2006, № 7, P.32. Disponible en: http://dialnet.unirioja.es/servlet/articulo?codigo=3992784.

${ }^{191}$ BEGG,D. FISCHER, S. DORNBUSCH, R. y FERNÁNDEZ DÍAZ, A. Economía. 8ª Ed. Ob. Cit. P.9 «En una economía autoritaria, una oficina pública de planificación decide qué se va a producir, cómo se va a producir y para quién se va producir. A continuación da detalladas instrucciones a los hogares, las empresas y los trabajadores". SAMUELSON, P.A. y NORDHAUS, W.D. Economía. 13를 Ed. Ob. Cit. P. 45 «Una economía autoritaria es aquella en la que la asignación de los recursos es decidida por el gobierno, obligando a los individuos y a las empresas a seguir los planes económicos del Estado».

192 REAL ACADEMIA ESPAÑOLA. "Mercado". En: Diccionario de la Lengua (En línea). http://buscon.rae.es/drael/SrvltConsulta?TIPO BUS=3\&LEMA=mercado (Consultado 02/12/2011). BEGG, D. FISCHER, S. DORNBUSCH, R. y FERNÁNDEZ DÍAZ, A. Economía. 8aㅗ Ed. Ob. Cit. P.9 «En los libres mercados, los individuos buscan su propio provecho sin dirección ni intervención del Estado». SAMUELSON, P.A. y NORDHAUS, W.D. Economía. 13"a Ed. Ob. Cit. P. 45 «El mecanismo de mercado es un tipo de organización económica en la cual los consumidores y las empresas resuelven conjuntamente a través del mercado los tres problemas fundamentales de la organización económica» 
En el supuesto de la economía autoritaria, en el que el Estado tiene el control total de los procesos y es propietario de los factores de producción no habría problema alguno en identificar el mercado como bien de dominio público. En contrapartida, el mercado libre difícilmente podría otorgar tal carácter pues su propia naturaleza aleja al Estado de toda participación en los procesos económicos. En la práctica no existe un sistema económico totalmente autoritario, ni uno totalmente apegado al libre mercado; en palabras de SAMUELSON, «el mercado no siempre se comporta de una manera ideal. De hecho, probablemente nunca ha habido un mercado competitivo absolutamente puro y perfecto, sino que en las economías de mercado hay monopolios, contaminación, desempleo, inflación y una distribución de la renta que a veces es inaceptable para los votantes. Ante estos fallos del mecanismo del mercado, las democracias han decidido introducir la mano visible del Estado en la economía mixta» ${ }^{194}$.

La participación del Estado en los mercados tiene una justificación ético jurídica, pues el fin primordial del Estado es el de garantizar el bien común ${ }^{195}$,

${ }^{193}$ BEGG,D. FISCHER, S. DORNBUSCH, R. y FERNÁNDEZ DÍAZ, A. Economía. 8ª Ed. Ob. Cit. P.9 «El Estado y el sector privado resuelven conjuntamente los problemas económicos». SAMUELSON, P.A. y NORDHAUS, W.D. Economía. 13" Ed. Ob. Cit. P.45 «Una economía mixta, en la que tanto las instituciones privadas como las públicas ejercen el control económico»

${ }^{194}$ SAMUELSON, P.A. y NORDHAUS, W.D. Economía. 13를 Ed. Ob. Cit. P.55

${ }^{195}$ BERZOSA, C. Mercado, Estado y Economía Mundial. Revista de Economía Mundial. 1999, no 1,P. 40 «El Estado necesita del mercado para que tenga lugar el desarrollo en el sistema capitalista, pero también el mercado necesita del Estado. Sin embargo, la función del Estado ha variado en los tiempos modernos y se ha pasado de un Estado apenas regulador del mercado, propio del siglo XIX, a un Estado que ha ido desempeñando un papel creciente en la 
de manera que las funciones del Estado en la economía son las de fomento de la eficiencia, la equidad y la estabilidad del mercado ${ }^{196}$. El marco jurídico

vida económica y que ha sido el rasgo principal del siglo XX. Este paso es fruto de la evidente decadencia del capitalismo y del mercado autorregulado (sic), de las transformaciones que el capitalismo estaba atravesando a finales del siglo XIX y principios del XX y también de una idea mantenida por Polanyi que me resulto muy sugerente y es que la sociedad tuvo que protegerse contra los peligros inherentes de un sistema de mercado autorregulador (sic). Así mientras los mercados se propagaban por toda la faz del globo, por la otra, una red de medidas y normas era integrada en instituciones poderosas destinadas a contener la acción del mercado relativa al trabajo, la tierra y el dinero». FERULLO, H. El Estado, el mercado y el proceso deliberativo de la sociedad civil. Revista Valores en la Sociedad Industrial. 2005, № 63, P. 20. Disponible en Web: http://dialnet.unirioja.es/servlet/articulo?codigo=1309101 «Cuando el pensamiento económico actual analiza el tema del Estado, como cualquier otra cuestión económica de cierta envergadura, lo hace en relación con el mercado. En ese contexto, la principal función que la teoría económica asigna al Estado es, justamente, la de servir de guardián del buen funcionamiento del mecanismo de mercado, de donde resulta la muy conocida predilección de los economistas por un Estado mínimo y coercitivo, dueño del poder político estrictamente necesario para definir con precisión los derechos de propiedad de las personas y para garantizar su defensa y seguridad". HÄBERLE, P. "Siete tesis para una teoría constitucional del mercado". Ob. Cit. P.13 «el mercado del Estado constitucional no es un espacio ajeno al Estado y a la ética. La «invisible hand" del mercado (A. Smith) y la "mano aseguradora del Derecho" (E.J. Mestmäcker) han de pensarse simultáneamente. La red de millones de contratos regulados por el Derecho, que requieren una confianza previa para ser realizados, se asemejan a los contratos sociales, que conducen desde el estado originario ("status naturales») al "status civilis vel culturalis», caracterizando así al Estado constitucional: contrato y carga permanente del ciudadano. El mercado es un sector abarcado por el contrato social: «life, liberty, estate, property» y el trabajo igual de todos las partes contratantes. El estudio empírico de las relaciones contractuales en el mercado ("socios de mercado") debería encontrar un vínculo entre las nuevas y las clásicas teorías del contrato (y teorías de la justicia, hasta J. Rawls). El mercado, como toda forma de vida social, está estructurado, funcionalizado, conformado normativamente y constituido jurídicamente en el Estado constitucional. En un punto de vista ideal y real se transforma desde el estado de naturaleza al estado de civilización: por ejemplo, a través de los postulados constitucionales materiales y procesales relativos a la justicia y el bien común».

196 SAMUELSON, P.A. y NORDhAUS, W.D. Economía. 13" Ed. Ob. Cit. P. 51 «Cuando analizamos el papel del Estado, generalmente damos por sentado que éste fija las normas de 
constitucional de la intervención del Estado en la economía se le denomina "Constitución Económica" ${ }^{197}$ que, de acuerdo con la jurisprudencia del Tribunal Constitucional Español «Designa el marco jurídico fundamental para la estructura y funcionamiento de la actividad económica o, dicho sea de otro modo, para el orden del proceso económico» ${ }^{198}$.

La Unión Europea no es ajena a esta construcción jurídico-económica en la que la mayor parte del Tratado de Funcionamiento de la Unión, y sus predecesores, tienen un espíritu de regulación netamente económica, ya que no en vano, sus antecedentes primarios fueron "La Comunidad Europea del Carbón y el Acero"199, y la "Comunidad Económica Europea”. Es, por lo tanto, su objetivo la consecución de esa unión económica y por supuesto su

tráfico, legislando y velando por el cumplimiento de los contratos. Pero ¿cuáles son sus funciones económicas? Fomentar la eficiencia, la equidad y la estabilidad. Las intervenciones del Estado relacionadas con la eficacia son intentos de corregir los fallos del mercado como el monopolio. Los programas públicos destinados a fomentar la equidad se valen de los impuestos del gasto para redistribuir la renta cuando la sociedad muestra su preocupación por los pobres o por determinados grupos. La política de estabilización intenta limar las cimas y los fondos del ciclo económico, reduciendo el desempleo y la inflación y fomentando el crecimiento económico».

${ }^{197}$ Que se pueden identificar en la Constitución Española en: Título VII "Economía y Hacienda" (Arts. 128 a 136); Capítulo III del Título I, "De los principios rectores de la Política social y económica" (Arts. 39 a 52), conjuntamente con los artículos 33, 38 y 149.1 apartados 10 y 13.

198 Sentencia del Tribunal Constitucional Español de fecha 16 de noviembre de 1981, en el asunto $184 / 1981$.

199 Tratado firmado el 18 de abril de 1951, en París, que entró en vigor el 23 de julio de 1952 y que se pactó por un periodo de cincuenta años, expirando el 23 de julio de 2002. 
preservación y desarrollo, tal y como se planteó en el primer capítulo en lo referente a las competencias de la Unión.

El artículo 26.2 del TFUE, se refiere a la estructura del mercado interior, que es uno de los elementos esenciales de la Unión, de cuya estructura podemos desprender su naturaleza demanial. El citado artículo prescribe: «El mercado interior implicará un espacio sin fronteras interiores, en el que la libre circulación de mercancías, personas, servicios y capitales estará garantizada de acuerdo con las disposiciones de los Tratados».

De la fragmentación de sus elementos encontramos, en primer lugar, que se refiere a un espacio físico territorial, en el que se garantizan la realización de sus otros elementos en forma de libertades, políticas y principios. Al hablar de un espacio físico, hablamos de un bien determinado del Estado, como lo es el territorio. En segundo término, el resto de sus elementos conforman bienes de carácter inmaterial que conjuntamente identifican al mercado común como una parte inherente a la propia Unión, pues basta con revisar cualquiera de los Tratados constitutivos ${ }^{200}$ o la reciente Comunicación de la Comisión (COM final $2010608)^{201}$ para verificarlo.

Resulta evidente que el mercado forma parte inherente al Estado y en este caso a la Unión Europea, por lo que resulta innecesario buscar la naturaleza de algo que es intrínseco a sí mismo. Sea cual sea la teoría en torno a la

\footnotetext{
${ }^{200}$ Verbigracia: Artículos 2, 3, 4, 14... todos del Tratado de la Comunidad Europea ${ }^{201}$ COM final 2010608 de fecha 27 de Octubre de 2010. Hacia un Acta del Mercado Único. Por una economía social de mercado altamente competitiva.
} 
naturaleza de los bienes demaniales, todas coinciden que un bien de dominio público es algo que por su propia naturaleza es inherente al Estado ${ }^{202}$ por lo que, bajo este contexto, la incorporación de una mercancía extranjera al circuito económico que se desarrolla al interior del mercado único es un acto de aprovechamiento de esos bienes materiales e inmateriales que componen el mercado. En este sentido, debe tenerse en cuenta que, siendo cierto que el mercado único es general y garantiza la libre circulación mercancías, esta libertad se constriñe a las mercancías comunitarias, es decir, a las que fueron producidas dentro del multicitado circuito económico, pues en palabras de BIELSA «En principio la disponibilidad de la cosa pública pertenece a la colectividad que ejerce esa facultad dentro de un régimen originalmente legal»203. Esto deja automáticamente fuera de ese derecho a las mercancías extracomunitarias, por lo que si se quiere que estas mercancías gocen de las mismas prerrogativas que las mercancías comunitarias, es necesario el pago del tributo que legítima su incorporación al circuito económico y que por lo tanto, puedan hacer uso de la estructura y libertades que se desarrollan en el circuito económico de la comunidad.

Sea cual sea la acepción de mercado a la que nos refiramos es evidente que siempre hablamos de un bien finito ${ }^{204}$, por lo tanto la incorporación de una

${ }^{202}$ Ver al respecto notas al pie de página 36 y 37.

${ }^{203}$ BIELSA, R. Derecho Administrativo. Tomo III. 6를. Ed. Ob. Cit. P. 500

${ }^{204} \mathrm{Si}$ nos referimos al mercado en su aspecto físico lógicamente tendrá una limitación territorial, si nos referimos al mercado como un sector también tiene sus limitantes en cuanto al número de consumidores posibles, etc. 
mercancía no comunitaria al circuito económico de la Comunidad, implicará una reducción de las cuotas de mercado, disminuyendo las oportunidades de comercialización de las mercancías comunitarias o inclusive pudiesen las mercancías extracomunitarias desplazar totalmente a las comunitarias en el mercado, lo que representa un menoscabo del bien común denominado mercado $^{205}$, siendo por lo tanto un uso especial de un bien de uso general ${ }^{206}$.

Muchos de los argumentos que formula Berliri para negar el carácter impositivo de los Derechos aduaneros ${ }^{207}$ tienen respuesta al concebir los Derechos aduaneros como tasas por el aprovechamiento de un bien de dominio público, como veremos a continuación.

Uno de los argumentos de mayor repercusión de los vertidos por Berliri es aquel que le niega el carácter impositivo a los Derechos de aduana en virtud de la variación del importe de estos derechos en función del origen de la mercancía; visto desde la perspectiva del impuesto se rompe con el principio

${ }^{205}$ Un lamentable ejemplo de ello lo tengo en mi país donde la importación de maíz de los Estados Unidos de Norte América, satura el mercado interno haciendo casi imposible para los productores locales lograr desplazar sus productos. Un ejemplo más seria el caso el de la industria zapatera en Elche que se ha visto casi al borde de la desaparición por la importación indiscriminada de zapato chino a España.

${ }^{206}$ PARADA, R. Derecho Administrativo III Bienes públicos. Derecho urbanístico. Ob. Cit. P. 63 "Como se advirtió, los principios de libertad, gratuidad e igualdad característicos del uso común general no son siempre fáciles de garantizar. Por ello sufren excepciones, que dan lugar a regímenes particulares, es decir, a usos comunes especiales. En esta categoría entran, como también se dijo, los usos en que concurren circunstancias singulares de peligrosidad, intensidad de uso o cualquiera otra semejante y que puede originar un exceso de utilización sobre el uso que corresponde a todos o un menoscabo de éste».

${ }^{207}$ Ver al respecto BERLIRI, A. "La obligación tributaria aduanera”. Aduanas. 272 -273. Ob. Cit. 
de capacidad contributiva, pues efectivamente el origen de la mercancía no revela una capacidad contributiva. Esto no ocurre si abordamos el tributo desde la perspectiva de las tasas ya que como es conocido, la capacidad contributiva en este tipo de tributos se mide por el principio del beneficio, al que le sumarian las características, la naturaleza del bien, su disponibilidad, los efectos que se causan con su aprovechamiento y la posibilidad de restitución del bien.

Lo anterior justificaría en parte la utilización de los parámetros de cuantificación de las tasas por prestación de servicios que propone MARTIN QUERALT, pues a nuestro gusto pueden establecerse fácilmente para el caso que nos ocupa, pues si bien es cierto nuestra tesis propuesta es la de una tasa por utilización de un bien de dominio público, dicha utilización no puede ser determinada en valores de mercado, máxime que se trata de un bien inmaterial, cuya reconstrucción o reparación no se da en medios físicos sino de equilibrio, que poco tienen que ver con el valor de mercado y la utilidad derivada de la utilización del bien. El mencionado Autor, indica que:

«Para determinar el importe de las tasas exigidas por la realización de una actividad administrativa o por la prestación de un servicio, hay que tomar en consideración los costes directos o indirectos, inclusive los de carácter financiero, amortización del inmovilizado y, en su caso, los necesarios para garantizar el mantenimiento y un desarrollo razonable del servicio o actividad por cuya prestación o realización se exija la tasa, con independencia del presupuesto con cargo al cual se satisfagan. Su cuantía no puede exceder, en su conjunto, del coste real o previsible de la actividad o, en su defecto, del valor 
de la prestación recibida. (....) Además, cuando la utilización privativa o el aprovechamiento especial del dominio público lleve aparejada una destrucción o deterioro del mismo no prevista en la memoria económico financiera, el sujeto pasivo, sin perjuicio del pago de la tasa a que hubiera lugar, estará obligado también al reintegro del coste total de los respectivos gastos de reconstrucción o reparación» ${ }^{208}$.

El origen de la mercancía, visto desde la perspectiva de la tasa, puede tener distinto coste para el Estado receptor en función de la reciprocidad que exista con el país de origen de la mercancía. Siendo el bien jurídico tutelado el mercado interior, se prevé que las mercancías que se incorporen a su circuito económico generen el menor desequilibrio posible, así pues las mercancías que provengan de un Estado con el que la Comunidad mantiene relaciones comerciales generará menos desequilibrio en función de la posibilidad de la incorporación de mercancías comunitarias en el circuito económico del Estado extranjero, estableciéndose un flujo entre ambos mercados que permite la estabilidad de ambos mercados y de su respectiva economía. Por el contrario si la mercancía procede de un Estado con el que la Comunidad no tiene acuerdos comerciales, las mercancías podrían entrar en competencia directa con las mercancías comunitarias sin la posibilidad de que los productos comunitarios pudieran incorporarse en el mercado del otro Estado, lo que conllevaría consigo un mayor riesgo de desequilibrio en el mercado y por ende un mayor coste para la Unión a fin de estabilizarlo.

\footnotetext{
${ }^{208}$ MARTÍN QUERALT, J. LOZANO SERRANO, C. CASADO OLLERO, G. TEJERIZO LÓPEZ, J. Curso de Derecho financiero y tributario. Ob. Cit. P. 96-97.
} 
En consecuencia, desde la perspectiva de la tasa por la utilización de bienes de dominio público, cobrar los Derechos de aduana de forma diferenciada dependiendo del origen de la mercancía no rompe con el principio de capacidad contributiva, pues el aprovechamiento del circuito económico por mercancías provenientes de orígenes distintos ocasiona un impacto distinto en el mercado interior que se refleja en un mayor o menor coste en el funcionamiento del mercado interior y por ende para la Comunidad.

Otra de las objeciones que se hacen respecto de la naturaleza impositiva de los Derechos de aduana es en torno a las divergencias existentes entre la declaración aduanera y la declaración tributaria tradicional, sobre todo en lo relativo a la posibilidad de modificación de las primeras frente a lo inmutable de las declaraciones en los impuestos. Esta posición apunta a la factibilidad de considerar los Derechos de aduana como tasas, pues como bien señala $\left.B E R L I R\right|^{209}$, la declaración aduanera hace del conocimiento de la autoridad el destino que tendrá la mercancía importada, pudiendo o no generarse la deuda aduanera según el destino, según veremos en capítulos siguientes. Ese destino de la mercancía puede traducirse, en primer lugar en declarar si la mercancía se incorporará o no al circuito económico; y en segundo lugar, la forma en que esa mercancía se incorporará, es decir, en qué forma utilizará el circuito pues no todos los destinos aduaneros son generadores de la deuda aduanera, ni todos incorporan la mercancía al circuito económico, ni todos lo hacen de igual

\footnotetext{
${ }^{209}$ BERLIRI, A. "La obligación tributaria aduanera”. Aduanas. 272 -273. Ob. Cit.
} 
forma, por lo que nuevamente vemos que el factor a gravar es la utilización del bien de dominio público.

Además de lo anterior, BERLIR| $\left.\right|^{210}$ objeta la exclusión de la obligación tributaria por la falta de pago, en el sentido de que si la mercancía queda abandonada en los términos del artículo 86 del Código aduanero modernizado, se extingue la obligación tributaria a diferencia de los impuestos, en los que subsiste la deuda. En este sentido habría que matizar la postura de BERLIRI: hay una extinción de la deuda tributaria pero no se realiza el supuesto de ley que da origen a la obligación tributaria, que es la incorporación de la mercancía al circuito económico, pues la mercancía queda en custodia de las autoridades aduaneras. Lo que no denota distinción alguna entre tipos de tributos, pues si no se realiza el hecho imponible, no nace obligación tributaria alguna.

Una vez demostrado que el hecho imponible genérico de los derechos arancelarios no puede ser considerado impuesto, es necesario apuntalar nuestra postura respecto a su naturaleza de tasa por utilización de un bien de dominio público, por lo cual es necesario ver todas las posibilidades. En párrafos anteriores comentamos que BERLIRI se había replanteado el considerar los derechos arancelarios como tasas por prestación de servicios y los ubicaba como gravámenes fiscales, por lo que procederemos a su análisis.

BERLIRI argumenta que: «Si se admite que el Derecho de Aduanas no es un impuesto, sino un gravamen fiscal pagado para que las mercancías puedan

${ }^{210}$ Ibidem 
pasar la línea aduanera y tomar el calificativo de mercancías nacionales, se deriva:

1. Que la posibilidad de aumentar los Derechos a titulo de retorsión mediante un decreto presidencial, no está en oposición con el artículo 23 de la Constitución.

2. Que no hay necesidad alguna de que la subida del gravamen esté en relación con la capacidad contributiva del importador y, por lo tanto, el legislador puede establecer la cuantía del Derecho en relación con la naturaleza de las mercancías y con los países de origen.

Además, la posibilidad de cambiar la declaración aduanera hasta el momento en que la mercancía es reconocida y de abandonar la misma, incluso después de la aceptación de la declaración, encuadra fácilmente en el esquema del gravamen tributario, mientras que la posibilidad de pasar la línea aduanera - es decir, el faltar, por efecto del pago de una suma, a la prohibición general de pasar dicha línea- y la adquisición de una condición jurídica particular por efecto del pago de una suma, son elementos típicos del gravamen fiscal»» ${ }^{211}$.

Vemos en las conclusiones aportadas por BERLIRI elementos por demás sugerentes respecto a la naturaleza de gravamen tributario de los Derechos aduaneros, sin embargo, el elemento que a mi gusto es el determinante, es sin duda alguna la autonomía que existe entre el ilícito tributario denominado contrabando y la deuda aduanera, pues indistintamente del surgimiento y

\footnotetext{
${ }^{211}$ BERLIRI, A. "La obligación tributaria aduanera”. Aduanas. 272 -273. Ob. Cit.
} 
represión del ilícito, surge la deuda aduanera. Además que la acción penal no se suspende por el pago de la deuda, ya que atienden a naturaleza y jurisdicciones distintas, pues la deuda aduanera como lo hemos expresado en este trabajo, es materia exclusiva de la Unión, en tanto la represión del ilícito y su tipificación siguen estando en la jurisdicción del Estado ${ }^{212}$. Por lo cual no se cumple con el requisito básico del gravamen fiscal, que es retirar una prohibición por efectos del pago de una suma.

${ }^{212}$ Verbigracia Ley Orgánica 6/2011, de 30 de junio, por la que se modifica la Ley Orgánica 12/1995, de 12 de diciembre, de represión del contrabando. 


\subsection{La importación regular}

Al inicio de este capítulo comentamos la pluralidad de hechos imponibles contemplados por el Código aduanero, la forma en que el Código aduanero modernizado los agrupa y nuestra propuesta de agrupamiento de acorde a la naturaleza o afinidad de los hechos imponibles específicos. Corresponde, por tanto, a este epígrafe, el estudio de los hechos imponibles que catalogamos como importación regular, es decir, aquellos que se realizan cumpliendo con todos los requisitos formales y materiales que establece la norma ${ }^{213}$, y que el Código aduanero modernizado agrupa en el artículo 44 (Anterior artículo 201) bajo el titulo Despacho a libre práctica e importación temporal ${ }^{214}$. Aun cuando ambos supuestos están contenidos en el mismo apartado y representan el medio jurídicamente correcto para realizar la importación, tienen características muy distintas que hacen necesario su estudio de manera independiente.

\subsubsection{El despacho a libre práctica}

El código aduanero modernizado describe en su artículo 129 (anterior artículo 79 del Código Aduanero) la aplicación, implicaciones y efectos del despacho a libre práctica. El apartado 1 indica su aplicación a todas «las mercancías no

${ }^{213}$ Clasificación que comparte CLAVIJO HERNÁNDEZ, F. Impuestos aduaneros. Ob. Cit. P. 757 quien le denomina «introducción legal de la mercancía en el territorio aduanero de la Comunidad»

214 La redacción entre ambos artículos es análoga, cuya única variante sustancial la encontramos en la redacción del último párrafo, en el cual el artículo 44 del CAM, ya no hace mención alguna a las «disposiciones nacionales vigentes» a las que se refería el artículo 201 del CA. 
comunitarias destinadas a ser introducidas en el mercado comunitario o destinadas a utilización o consumo privados dentro de la Comunidad».

Aplicaciones que, como se pueden observar, comprenden los elementos objetivos del hecho imponible aduanero comunitario que estudiamos en el epígrafe anterior y que es común a la generalidad de hechos imponibles específicos. La particularidad del despacho a libre práctica respecto del ya estudiado hecho imponible genérico se encuentra por una parte en las implicaciones o deberes formales y materiales previstos en el apartado 2, los cuales se deben cumplir para que las mercancías puedan ser legalmente introducidas en el mercado comunitario o destinadas a utilización o consumo privados dentro de la Comunidad, que es el verdadero hecho imponible y no el despacho a libre práctica, que es la formalización de esa introducción legal ${ }^{215}$. Por otra parte el efecto o estatus de mercancías comunitarias que concede el despacho a libre práctica a las mercancías no comunitarias, en el apartado 3, es sin duda alguna otro elemento accesorio y de distinción, respecto del hecho imponible genérico. Estas particularidades serán objeto de estudio a continuación.

${ }^{215}$ CLAVIJO HERNÁNDEZ, F. Impuestos aduaneros. Ob. Cit. P. 757 «el hecho imponible no es, como pudiera parecer en una rápida lectura del Código Aduanero, «el despacho a libre práctica de una mercancía», sino la introducción legal de la mercancía en el territorio aduanero de la Comunidad, como ya había señalado en el Derecho español la profesora Agulló Agüero, en relación con el Texto refundido de la Renta de Aduanas de 1977. La introducción legal de la mercancía, (...) es una entrada, cualificada por su destino o intención, que se pone de manifiesto a través de una serie de actuaciones exigidas por el Código Aduanero Comunitario a la persona que introduce las mercancías y que nos permite afirmar que se trata de un «hecho" distinto a la importación, en cuyo proceso queda inserta» 


\subsubsection{Las implicaciones del despacho a libre práctica.}

La revisión de las implicaciones que marca el párrafo 2 del artículo 129, es decir, de las obligaciones formales y materiales que se deben de cumplir para despachar una mercancía a libre práctica, nos confirman que el despacho a libre práctica no es ni puede ser el hecho imponible de la tributación aduanera, pues no es un presupuesto de hecho que dé nacimiento a tributo alguno, sino que es el resultado del cumplimiento de las diversas obligaciones formales y materiales a que está sujeta la importación ${ }^{216}$. Como se desprende del propio texto del artículo, el cumplimiento de dichas obligaciones representa no sólo el pago de los Derechos a la importación sino que, como pone de manifiesto el referido apartado, implica el pago de otros gravámenes que se generen, además de la aplicación de las medidas de política comercial y formalidades aduaneras $^{217}$.

\footnotetext{
216 IBIDEM. P.758 «<el despacho a libre práctica>, que supone, como examinaremos, el cumplimiento de las formalidades aduaneras previstas en el proceso de importación y pago de los Derechos de importación. De ahí que haya que afirmar en rigor jurídico que el hecho imponible que aparece contemplado en el Código Aduanero Comunitario no es el despacho a libre práctica de la mercancía, sino la introducción legal de la mercancía en el territorio aduanero de la Comunidad, que inexorablemente conducirá a dicho despacho a libre práctica»

217 En el mismo sentido apunta BERR, C,J. y TRÉMEAU, H. Le droit douanier Communautaire et national. 6a Ed. Paris: Economica, 2004, P. 215 «En ce qui concerne la mise en libre pratique, il y a lieu d'ajouter à cette situation le cas de marchandises placées sous le régime national de la mise à la consommation qui couvre toutes les obligations auxquelles sont assujettis les importateurs tant au regard du droit communautaire que du droit national: exigences relatives à la mise en libre pratique et obligations découlant de réglementations nationales diverses".
} 
Esta serie de implicaciones fueron introducidas por el Código aduanero modernizado, ya que en el artículo 79 del Código aduanero, tan solo se contemplaban como implicaciones el pago de los Derechos de aduana y la aplicación de las medidas de la política comercial. El nuevo texto incorpora otras implicaciones como son el pago de otros gravámenes que se generen por la importación y la obligación del cumplimiento de las demás formalidades aduaneras, abarcando con ello la totalidad de obligaciones formales y materiales requeridas para la legal importación de una mercancía a territorio comunitario. Desaparece con ello la distinción existente entre despacho a libre práctica y despacho a consumo, ya que la diferencia entre ambos despachos consistía en que este último era más amplio que el de libre práctica pues incorporaba el pago de otros impuestos, lo que no contemplaba el despacho a libre práctica ${ }^{218}$.

${ }^{218}$ CLAVIJO HERNÁNDEZ, F. Impuestos aduaneros. Ob. Cit. 781 «El despacho «a consumo» o importación a consumo; a diferencia del de libre práctica, este despacho supone, no sólo el cumplimiento de las formalidades aduaneras y pago de los correspondientes Derechos de importación, sino también el pago de los restantes impuestos indirectos aplicables (IVA e impuestos especiales, en su caso), de modo que la mercancía pueda ser «consumida» en el mercado interno e incorporarse a la corriente económica nacional en las mismas condiciones que el resto de las mercancías nacionales". IBAÑEZ MARCILLA, S. "Tributos Aduaneros". En: CAYON GALIARDO, A.; MARTÍN QUERALT, J.; y TEJERIZO LOPEZ, J.M. (Directores). Manual de Derecho Tributario parte especial. 2a Ed. Navarra: Thomson Aranzadi, 2004. P.764 "La distinción entre «despacho a libre práctica» $y$ «despacho a consumo». El segundo de los conceptos referidos comporta, además del contenido del primero, que se han satisfecho pro las mercancías los tributos internos al consumo que correspondan a las mercancías de que se trate (fundamentalmente, IVA a la importación e Impuestos Especiales, en su caso)».MINISTERIO DE ECONOMÍA Y HACIENDA. "Deuda aduanera”. En: Revista aduanas Informa sobre Comunidades Europeas. No. 31. Mayo - Junio 1989. P.7 «... como es sabido el despacho a consumo supone, no solo el cumplimiento de las formalidades aduaneras y el pago 
a) La percepción de los Derechos de importación debidos.

Al ser la deuda aduanera la obligación de pago del importe de los Derechos de importación o exportación debidos, resulta evidente la incorporación de esta obligación al despacho a libre práctica. Esta obligación de pago ya tratada en el supuesto genérico, adquiere en este supuesto como nota distintiva la legalidad y formalidad que no son elementos esenciales en el supuesto genérico, pero que sin embargo desvanecen cualquier duda respecto al carácter tributario de los Derechos de aduana. Si bien anteriormente establecimos que la legalidad o ilegalidad de la incorporación de la mercancía en el circuito económico no era una condicionante para la determinación de su carácter tributario ${ }^{219}$, el hecho de que se establezca el pago del tributo en estricto apego a la legalidad y por el cumplimiento de una obligación generada por la realización del supuesto a que la ley le atribuye el deber de contribuir, diluye cualquier duda respecto a la naturaleza tributaria de los Derechos arancelarios.

b) La percepción, según proceda, de otros gravámenes, con arreglo a las disposiciones pertinentes en vigor relativas a la percepción de dichos gravámenes.

La incorporación de esta obligación hace desaparecer la diferencia entre el despacho a libre práctica y el despacho a consumo y por otra parte deja claro

de los correspondientes Derechos y gravámenes de importación sino también el pago de otros impuestos indirectos como el IVA y los II.EE., los cuáles quedan fuera de la obligación aduanera propiamente dicha»

${ }^{219}$ En virtud de que tributo y sanción se derivan de jurisdicciones distintas, y por lo tanto la obligación tributaria y la sanción nacen de forma paralela 
que el despacho a libre práctica no es ni puede ser el hecho imponible de la tributación aduanera, al no ser un supuesto de hecho al que la ley le atribuye el deber de contribuir, sino el conjunto de obligaciones formales y materiales por la que se concreta la importación legal de la mercancía, dejando a la mercancía en aptitud de incorporarse legalmente en el circuito económico.

El hecho de que el despacho a libre práctica incorpore dentro de sus implicaciones el pago de otros gravámenes es un elemento más para determinar que no se trata de hecho imponible alguno y menos aún de los Derechos arancelarios, pues el propio Código aduanero modernizado en el artículo 4. 13) ${ }^{220}$, determina que la deuda aduanera es: «la obligación de una persona de pagar el importe de los Derechos de importación o exportación aplicables a mercancías específicas con arreglo a la legislación aduanera vigente».

En consecuencia, la deuda aduanera está comprendida única y exclusivamente por los Derechos de importación y exportación, entendiendo por tales los derechos de aduana $^{221}$ que se tienen que pagar por la importación o exportación de la mercancía según sea el caso $^{222}$. Cabe destacar que en el

\footnotetext{
${ }^{220}$ Al igual que su antecesor el Código aduanero comunitario en el artículo 4.9)

${ }^{221}$ Los Derechos de aduana son según el Capítulo 2 del Anexo General de la Convención de Kyoto, son: «los Derechos establecidos en los aranceles de Aduana, a los cuales se encuentran sometidas las mercancías tanto a la entrada como a la salida del territorio aduanero».

${ }^{222}$ Código aduanero modernizado artículo 4, apartados «15) «Derechos de importación»: los Derechos de aduana que deben pagarse por la importación de mercancías; 16) «Derechos de exportación»: los Derechos de aduana que deben pagarse por la exportación de mercancías».
} 
anterior Código aduanero comunitario se establecían como Derechos de importación en el artículo 4, apartado 10) «los Derechos de aduana y exacciones de efecto equivalente establecidos para la importación de las mercancías, los gravámenes a la importación establecidos en el marco de la política agrícola común o en el de los regímenes específicos aplicables a determinadas mercancías resultantes de la transformación de productos agrícolas».

La exclusión en el nuevo código de elementos anteriormente considerados como integrantes de los derechos de importación obedecen, en primer lugar, a que como señala PELECHA ZOZAYA, «las exacciones de efecto equivalente a Derechos de aduanas son, normalmente, tributos de carácter nacional destinados a nutrir las arcas de los Estados miembros» ${ }^{223}$, por lo cual quedan al margen de la tributación aduanera comunitaria, además de existir una prohibición expresa de su aplicación, como hemos visto en el capítulo anterior $^{224}$. Por lo que se refiere a las exacciones de efecto equivalente que tuvieran su origen en la normativa comunitaria, al igual que los gravámenes provenientes de la PAC, la Unión Europea, tras su incorporación a la Organización Mundial de Comercio $^{225}$, se comprometió a eliminar dichas

${ }^{223}$ PELECHA ZOZAYA, F. El Código Aduanero Comunitario y su aplicación en España. 1ª Ed. Madrid: Marcial Pons, 1995, P. 140.

\footnotetext{
${ }^{224}$ Ver al respecto el apartado 1.1.2.1 La supresión entre los Estados miembros de los derechos de aduana de importación y exportación o exacciones de efecto equivalente.

${ }^{225} 01$ enero de 1995
} 
figuras e incorporarlas como Derechos arancelarios ${ }^{226}$. En consecuencia, dentro de la deuda aduanera, no se contempla el IVA u otro tipo de tributo $^{227}$, que sí están contenidos en el despacho a libre práctica.

${ }^{226}$ STJCE de 25 de noviembre de 2010, asunto C-213/09, en el Caso: Barsoum Chabo y Hauptzollamt Hamburg-Hafen. Apartado 29. «Por el contrario, la imposición de un Derecho de aduana, como aquel sobre cuyo montante versa la cuestión de validez planteada por el órgano jurisdiccional remitente, constituye la única medida que las instituciones de la Unión Europea podían adoptar en relación con las importaciones de las mercancías en cuestión con arreglo a los compromisos asumidos por la Unión en el marco de la OMC. En efecto, del artículo 4 del Acuerdo sobre la Agricultura se desprende que todas las barreras comerciales no arancelarias en el sector agrícola deben quedar suprimidas y convertidas en Derechos de aduana, y que los tipos máximos de esos Derechos de aduana quedan establecidos en las listas de concesiones de los miembros de la OMC». RONDA DE URUGUAY. Acuerdo sobre la Agricultura. Parte III: Artículo 4. Acceso a los mercados. "1.Las concesiones sobre acceso a los mercados consignadas en las Listas se refieren a consolidaciones y reducciones de los aranceles y a otros compromisos en materia de acceso a los mercados, según se especifique en ellas. 2 Salvo disposición en contrario en el artículo 5 y en el Anexo 5, ningún Miembro mantendrá, adoptará ni restablecerá medidas del tipo de las que se ha prescrito se conviertan en Derechos de aduana propiamente dichos».

${ }^{227}$ STJCE de 29 de julio de 2010, asunto C-248/09, caso: Pakora Pluss SIA y Valsts ieņēmumudienests. «44. Según el artículo 4, punto 10, del Código aduanero, los Derechos de importación comprenden, entre otros, los Derechos de aduana y exacciones de efecto equivalente establecidos para la importación de las mercancías. 45. Por otra parte, el artículo 2, apartado 2, de la Sexta Directiva establece que las importaciones de bienes están sujetas al IVA. El artículo 11, parte B, apartado 3, letra a), de dicha Directiva precisa en particular que los impuestos, Derechos, exacciones y demás gravámenes que se devenguen con motivo de la importación, excepto el IVA que haya de percibirse, deben incluirse en la base imponible en la medida en que no lo estén. 46. De estas disposiciones resulta que los Derechos de importación, en el sentido del artículo 4, punto 10, del Código aduanero, están incluidos en la base imponible del IVA que haya de percibirse por la importación de bienes. 47. Por consiguiente, procede responder a la cuarta cuestión que el artículo 4, punto 10, del Código aduanero debe interpretarse en el sentido de que los Derechos de importación no incluyen el IVA que haya de percibirse por la importación de bienes». 
Otra peculiaridad es la falta de uniformidad en la aplicación de otros gravámenes. Verbigracia el caso del IVA, el cual se encuentra armonizado por la Directiva 112/2006, sin embargo la Directiva marca tan solo un límite inferior del $15 \%{ }^{228}$, lo que provoca marcadas diferencias en cuanto a los tipos aplicables entre los distintos Estados miembros. De igual forma los impuestos especiales están normados por la Directiva 118/2008, la cual establece tipos mínimos aplicables a determinados productos, pero no establece un tipo único, provocando el mismo efecto de disparidad.

La conclusión respecto a la implicación de la percepción de otros gravámenes, como parte del despacho a libre práctica, no puede ser otra más que la incompatibilidad de esta figura con el concepto del hecho imponible, pues como vimos, se trata de una figura que engloba un sinfín de tributos y que por sí misma no es cuantificable.

c) La aplicación de medidas de política comercial y de prohibiciones y restricciones en la medida en que no se hayan aplicado en una fase anterior.

Como se vio en el capítulo anterior, el artículo 207 TFUE (antiguo artículo 133 TCE) vela por la uniformidad de principios relativos al intercambio comercial con terceros países, modificaciones arancelarias, celebración de acuerdos arancelarios y comerciales, medidas de liberalización, políticas de exportación, medidas de protección comercial, dumping y subvenciones en los que se basa la Política Comercial Común. El ámbito de aplicación de los referidos principios constituye las medidas a que hace referencia el apartado en estudio, medidas

\footnotetext{
${ }^{228}$ Límite fijado por la Directiva 88/2010, que modifica el artículo 97 de la directiva 112/2006.
} 
que en su mayoría afectan directa o indirectamente al nacimiento y/o importe de la deuda aduanera y que vienen reguladas en distintos Reglamentos.

El Reglamento 260/2009 sobre el régimen común aplicable a las importaciones, en palabras de la propia Comisión, tiene por objeto: «establecer un régimen común aplicable a las importaciones en la Comunidad Europea (CE) que se base en el principio de la libertad de importación y definir los procedimientos para que la Comunidad aplique, en caso de necesidad, las medidas de vigilancia y de salvaguardia pertinentes para proteger sus intereses» ${ }^{229}$.

Las medidas de vigilancia establecen un régimen aduanero especial, de carácter netamente formal, sin crear directamente una obligación de pago, salvo en caso de su incumplimiento, del que hablaremos más adelante cuando nos ocupemos del estudio de la deuda aduanera por incumplimiento. Las medidas de salvaguardia ${ }^{230}$ por su parte pueden consistir en cambiar la

${ }^{229}$ COMISIÓN EUROPEA. "Régimen común aplicable a las importaciones". En: Síntesis de legislación. Disponible en: http://europa.eu/legislation summaries/external trade/r11002 es.htm. Este reglamento es adoptado en base al artículo XIX del Acuerdo General, el cual "autoriza a los miembros del GATT a adoptar medidas de "salvaguardia" para proteger a una determinada rama de producción nacional de un aumento imprevisto de las importaciones de cualquier producto que cause, o pueda causar, un perjuicio grave a dicha rama de producción» Organización Mundial del Comercio. "Resumen del Acta Final de la Ronda Uruguay". En: Textos jurídicos: Los Acuerdos de la OMC. Disponible en: http://www.wto.org/spanish/docs_s/legal_s/ursum_s.htm\#lAgreement.

${ }^{230}$ Organización Mundial del Comercio. Información técnica sobre salvaguardias. Disponible en: http://www.wto.org/spanish/tratop s/safeg s/safeg info s.htm «Las medidas de salvaguardia se definen como medidas "de urgencia" con respecto al aumento de las importaciones de determinados productos cuando esas importaciones hayan causado 0 amenacen causar un daño grave a la rama de producción nacional del Miembro importador 
duración de la validez de los documentos de importación establecidos en caso de vigilancia o bien establecer un procedimiento de autorización de importación y, especialmente, establecer contingentes de importación.

Por lo general los contingentes tienen un sentido permisivo en tanto determinan la cantidad de mercancía que puede ingresar al territorio comunitario en un periodo determinado, con tarifas preferenciales o libres de derechos arancelarios $^{231}$. En lo que se refiere a los contingentes como medidas de (artículo 2). Esas medidas, que en general adoptan la forma de suspensión de concesiones u obligaciones, pueden consistir en restricciones cuantitativas de las importaciones o aumentos de los Derechos por encima de los tipos consolidados».

${ }^{231}$ Asociación Latinoamericana de Integración. Glosario, Voz: Contingente. [En línea]Fecha Consulta: 11/09/2015. Disponible en web: http://www.aladi.org/nsfaladi/vbasico.nsf/vbusqueda/47FAA8B29343D48E032574A2005B2528 «Volumen o monto de las importaciones de un producto determinado que un país se compromete a aceptar en su mercado, como parte de los compromisos de acceso mínimo o acceso corriente, sin aplicar medidas restrictivas al acceso de dicho producto. Los Contingentes o Cuotas de importación se consideran barreras no arancelarias cuando no forman parte de un acuerdo específico de acceso al mercado en el marco de un acuerdo comercial multilateral o bilateral». Comisión Europea. Trade Glosary. Disponible en: http://ec.europa.eu/trade/glossary. "Quota - The quantity of goods of a specific kind that a country permits to be imported without restriction or imposition of additional duties».DE FRANCISCO, V. Contingentes arancelarios y contingentes cuantitativos : rebajas y veda en el comercio internacional [En línea]. Fecha publicación: 14/05/2004. Fecha Consulta:11/09/2015. Disponible en web: http://www.comercio-exterior.es/es/action-articulos.articulos+art-78+cat$10+$ pag-

2/Articulos+de+comercio+exterior/Aduanas/Contingentes+arancelarios+y+contingentes+cuantit

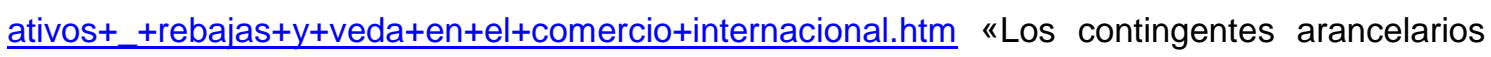
hacen referencia a unas determinadas cantidades de mercancía de importación en la UE, que durante cierto período de tiempo, están total o parcialmente exentas del pago de Derechos arancelarios. Los contingentes arancelarios en los países de la UE tienen carácter comunitario $y$, en consecuencia, son establecidos por la Comisión Europea y publicados en el DOCE (Diario Oficial de la UE). Por otra parte, el TARIC refleja los contingentes existentes del siguiente modo: señala su existencia con una letra $R$ (situada junto a los Derechos a pagar) y 
salvaguarda se presentan en dos formas distintas, la primera como un incremento en el tipo aplicable a las mercancías provenientes de un país determinado y/o que sobrepasen la cantidad permitida ${ }^{232}$. La segunda consiste en una limitación en cuanto al tiempo y volumen de la mercancía susceptible a ser importada, que puede llegar a una prohibición total de importación de determinada mercancía, siendo conocido este tipo de contingentes como $\operatorname{cupos}^{233}$. La mayoría de estas medidas limitantes son aplicables junto con los Derechos arancelarios o están integradas en los mismos por lo que su aplicación se da en el mismo proceso de la constricción de la deuda.

posteriormente indica el DOCE donde se hallan regulados.
A través de un contingente, durante un período de tiempo determinado, se concede la posibilidad de importar una determinada cantidad de mercancía originaria de un determinado país, sin satisfacer Derechos arancelarios o satisfaciendo Derechos arancelarios inferiores a los que correspondería pagar en situación normal».

232 Verbigracia: Reglamento 1864/2004 relativo a la apertura y el modo de gestión de contingentes arancelarios de conservas de setas importadas de terceros países.

${ }^{233}$ Artículo 17 del Reglamento 260/2009. "Cuando así lo requieran los intereses de la Comunidad, el Consejo, por mayoría cualificada y previa propuesta de la Comisión, elaborada según el procedimiento previsto en el capítulo III, podrá adoptar las medidas adecuadas para impedir que se importe en la Comunidad un producto en cantidades tan elevadas o en condiciones tales que se provoque o corra el riesgo de provocar un perjuicio grave a los productores comunitarios de los productos similares o directamente competidores». Asociación Latinoamericana de Integración. Glosario, Voz: Cupos. [En línea]Fecha Consulta: 11/09/2015. Disponible en web: http://www.aladi.org/nsfaladi/vbasico.nsf/vbusqueda/A242350077A749490325749C006BB0C0 «Medida de protección que sirve para limitar las importaciones o exportaciones de mercancías en su valor o cantidad. Los cupos pueden ser: globales (que se permite exportar o importar un volumen total de mercaderías sin tener en cuenta su procedencia o por países (discriminándose la asignación del límite admisible en función a los países de origen)» 
Otras medidas que son adoptadas por la política comercial común son las relativas a las disposiciones antidumping, reguladas por el Reglamento 1225/2009, en apego a lo previsto por el artículo VI del GATT de 1994. Estas medidas, a diferencia de las anteriores, se establecen en contra de productos que gozan de una subvención o precio inferior para su exportación respecto del que aplica en su mercado interior, realizando con ello una competencia desleal $^{234}$. Pero al igual que los Derechos de salvaguardia, los Derechos antidumping se determinan con un aumento en los tipos arancelarios por lo cual no son aplicables en un momento posterior ${ }^{235}$, y sin duda afectan la deuda aduanera.

En conclusión, las medidas de política comercial en su gran mayoría se reflejan en los elementos cuantitativos del tributo en forma de tipos diferenciados, no siendo aplicables en fases posteriores, por lo que las implicaciones a las que se refiere el apartado c) del artículo 129, se reducirían a algún tipo de restricciones a la importación por cuestiones sanitarias, de propiedad

\footnotetext{
${ }^{234}$ Organización Mundial de Comercio. Glosario de términos, Voz: Derechos antidumping. [En línea]Fecha Consulta: 11/09/2015. Disponible en web: http://www.wto.org/spanish/thewto s/glossary s/Derechos antidumping s.htm «El artículo VI del GATT permite la imposición de Derechos antidumping a las importaciones que se considera son objeto de dumping y causan daño a los productores de productos competidores en el país importador. Estos Derechos son equivalentes a la diferencia entre el precio de exportación de las mercancías y su valor normal, si el dumping causa daño».
}

235 Ejemplo: Partida Arancelaria 87120030. Correspondiente a Bicicletas. Derecho ERGAOMNES 14.00\%. Procedente de China, Derecho Antidumping definitivo (15-07-2005): 48.50\% (Reglamento 838/06). Procedente de México: 0\% (Preferencias arancelarias). 
intelectual o seguridad, como lo deja claro el artículo 1.7 del Reglamento $2454 / 93^{236}$

d) el cumplimiento de las demás formalidades aduaneras previstas para la importación.

Este apartado en particular no tiene mayor relevancia en torno al surgimiento de la obligación tributaria, en tanto se tratan de obligaciones formales y no de carácter impositivo, reforzando con ello el argumento de que el despacho a libre práctica no es ni puede ser considerado como hecho imponible de los derechos arancelarios, pues está compuesto por un sinfín de particularidades ajenas a cualquier naturaleza económica.

\subsubsection{El efecto del despacho a Libre práctica.}

El apartado 3 del artículo 129 del CAM, señala que «el despacho a libre práctica conferirá a las mercancías no comunitarias el estatuto aduanero de mercancías comunitarias". Este efecto remite de nuevo al debate en torno al hecho imponible de los tributos aduaneros y a su naturaleza jurídico tributaria. Si bien es cierto que en el epígrafe anterior relativo al hecho imponible

\footnotetext{
${ }^{236}$ Reglamento (CEE) № 2454/93 De La Comisión de 2 de julio de 1993, Por el que se fijan determinadas disposiciones de aplicación del Reglamento (CEE) n o 2913/92 del Consejo por el que se establece el Código Aduanero Comunitario. Artículo 1.7 «Medidas de política comercial: las medidas no arancelarias establecidas, en el marco de la política comercial común, por disposiciones comunitarias aplicables a las importaciones y a las exportaciones de mercancías, tales como las medidas de vigilancia o de salvaguardia, las restricciones o límites cuantitativos y las prohibiciones de importación o exportación»;
} 
genérico, nos referimos de manera general a la nacionalización de la mercancía como hecho imponible de los Derechos arancelarios, concluimos en ese supuesto genérico que era inoperante, pues desde la perspectiva genérica no se cumplían los requisitos previstos en las formas y modos ya expuestos ${ }^{237}$. En el supuesto específico que nos ocupa el planteamiento es distinto, primero por tratarse de algo expresamente contemplado en la norma y, segundo, por tener características análogas mas no iguales, al supuesto anterior.

Así mismo ha de partirse de la reiteración de que en el supuesto que nos ocupa habremos de referirnos única y exclusivamente a la "importación legal y definitiva de la mercancía", excluyendo por lo tanto cualquier otra figura de importación, como "despacho de libre práctica" o importación temporal. El primero, como hemos visto, no se trata de un hecho imponible sino un conjunto de supuestos formales a cumplirse conjuntamente con la obligación de pago de los Derechos arancelarios ${ }^{238}$, en tanto la importación temporal se trata de otro supuesto totalmente distinto.

CORTES DOMINGUEZ encabezó por parte de la doctrina española la teoría de la nacionalización de las mercancías como el hecho imponible de los Tributos aduaneros argumentando ${ }^{239}$, en primer lugar, que «la nacionalización supone el

\footnotetext{
${ }^{237}$ Ver al respecto el epígrafe 2.1 de esta tesis.
}

${ }^{238}$ STJCE de 15 de diciembre de 1976, asunto C-41/76, en el caso: Donckerwolcke. Apartado 17. «que del artículo 9 resulta, por lo que se refiere a la libre circulación de mercancías en el interior de la Comunidad, que los productos que se encuentran en «libre práctica» se equiparan definitiva y totalmente a los productos originarios de los Estados miembros».

${ }^{239}$ Si bien es cierto la doctrina posterior a CORTES DOMINGUEZ no sigue la teoría formulada por esté respecto a la nacionalización de la mercancía como hecho imponible de los derechos 
acceso a la categoría de mercancías nacionales. No se trata, por tanto, exactamente de un destino al consumo interno, sino más bien de la posibilidad de ese consumo, de la susceptibilidad de que se produzca el consumo» ${ }^{240}$. Esta postura confirma nuestra posición respecto al hecho imponible genérico en el que se identifica el hecho imponible con la posibilidad de consumo de la mercancía en el territorio aduanero, con la variante del estatus de legalidad que le confiere la adopción del carácter de comunitaria o nacional a una mercancía que no lo es, frente al supuesto genérico en que la susceptibilidad de consumo no siempre se da en un marco de legalidad. Así el factor determinante en este supuesto es la legitimidad de acceso de la mercancía al circuito económico, legitimidad que se concreta con el otorgamiento del estatus de mercancía comunitaria, lo que permite que la mercancía pueda incorporarse en el circuito económico de la Comunidad en paridad de condiciones con las mercancías comunitarias $^{241}$. Esta conceptualización en cualquier caso, no es novedosa

arancelarios, es el referente primordial de esta teoría y son sus argumentos la base del debate respecto a la Teoría que nos ocupa. Basta revisar a los ya multicitados AGULLÓ AGÜERO, CLAVIJO HERNANDEZ y SÁNCHEZ GÓNZALEZ para confirmarlo.

240 CORTÉS DOMínGUEZ, M. "Introducción al Derecho aduanero". En: Aduanas, № 166 (Noviembre 1967) P. $3-9$.

${ }^{241}$ Respecto a la equiparación de mercancías extracomunitarias y comunitarias ver: STJCE de 15 de diciembre de 1976, asunto C-41/76, en el caso: Donckerwolcke. Apartado 18. "Que el artículo 9 del Tratado parece que, en lo que concierne a la libre circulación de mercancías en el interior de la Comunidad, los productos que se beneficien de la «libre práctica» son asimilados total y definitivamente a los productos originarios de los Estados miembros". STJCE de 23 de septiembre de 2003, asunto C-30/01, en el caso: Comisión Europea vs Reino Unido. Apartado 54 «Del artículo 23 CE se desprende que, por lo que se refiere a la libre circulación de mercancías en el interior de la Comunidad, los productos que se encuentran en libre práctica se equiparan definitiva y totalmente a los productos originarios de los Estados miembros. Dicha 
pues DI LORENZO ${ }^{242}$ ya definía en términos similares a la importación en su sentido técnico aduanal.

Como toda teoría, tiene sus detractores ${ }^{243}$, entre los que se encuentra AGULLÓ AGÜERO, quien argumenta que el hablar de la nacionalización como hecho imponible de los Derechos a la importación se trata de una confusión terminológica entre los conceptos de importación y nacionalización que, en su opinión, se pretenden homologar en esta teoría ${ }^{244}$. La autora tiene a bien diferenciar ambos términos apuntando que: «la nacionalización, sin entrar en la naturaleza de la misma, es algo que se produce por el pago de los Derechos

equiparación supone que las disposiciones del artículo $28 \mathrm{CE}$, relativas a la supresión de las restricciones cuantitativas y de cualquier medida de efecto equivalente, son indistintamente aplicables a los productos originarios de la Comunidad y a los que hayan sido despachados a libre práctica en cualquiera de los Estados miembros, independientemente del origen de dichos productos (véase la sentencia Donckerwolcke y Schou, antes citada, apartados 17 y 18)».

${ }^{242}$ DI LORENZO, M. Inztituzioni di diritto Doganale. Vol 2. Roma: Guido Pastena Editore, 1958, P. 173 «Lí importazione é, nel senso tecnico doganale, l'operazione mediante la quale si sottopone una merce ai permessi e controlli prescritti e ai conseguentiadempimenti tributrari per poterla poi destinare liberamente a una funzione economica di uso, di produzione o di consumo, al pari de una merce similare nazionale»

${ }^{243}$ AGULLÓ AGÜERO, CLAVIJO HERNANDEZ, SÁNCHEZ GÓNZALEZ.

244 AGULLÓ AGÜERO, A. La renta de Aduanas: configuración técnico jurídica y aspectos penales. Ob. Cit. P. 44 «A nuestro entender, la confusión arranca de atribuir a los conceptos de importación y nacionalización un mismo significado. Estos conceptos ciertamente pueden ser identificados desde un punto de vista económico si es que es posible hablar de nacionalización en sentido económico, en tanto en cuanto los dos aluden a mercancías extranjeras que están equiparadas a las mercancías nacionales en el mercado interior, pero de ningún modo se produce esta confusión desde el punto de vista jurídico». 
de Arancel, mientras que la importación es algo que obliga al pago de los citados Derechos ${ }^{245}$.

No obstante, a mi juicio, de acuerdo con la interpretación del TJCE y de la OMA importación es: «el acto de introducir o de actuar para que se introduzca en un territorio aduanero cualquier mercancía» ${ }^{246}$, lo que no siempre lleva aparejada la obligación de pago, pues el fin que se persigue con la introducción de la mercancía en el territorio aduanero no es en todos los casos incorporarla al circuito económico de la Comunidad, que es el hecho gravado según vimos en el epígrafe anterior. La nacionalización por su parte, se refiere a la acción de otorgar a las mercancías procedentes de un tercer país los Derechos y deberes de las mercancías comunitarias ${ }^{247}$ para que sean susceptibles de incorporarse al circuito económico de la Comunidad en igualdad de circunstancias, evitando con ello cualquier disparidad que atentara en contra del flujo natural del circuito económico.

${ }^{245}$ IBIDEM.

${ }^{246}$ World Customs Organization.Glossary Of International Customs Terms. Bruselas, 2006. P.16 Ob. Cit.

247 Ver al respecto Diccionario de la Real Academia de la Lengua Española. Voces: Nacionalización, Nacionalizar y Naturalizar. (En Línea) consultadas: 17/09/2015. Disponible en: http://buscon.rae.es/drael/SrvltConsulta?TIPO BUS=3\&LEMA=nacionalizaci\%F3n

http://buscon.rae.es/drael/SrvltConsulta?TIPO BUS=3\&LEMA=nacionalizar

http://buscon.rae.es/drael/SrvltConsulta?TIPO BUS=3\&LEMA=naturalizar 
Ahora bien, la ruptura cronológica que argumentan tanto AGULLÓ AGÜERO como FELIPE GARRE ${ }^{248}$, al realizarse la nacionalización como consecuencia del pago del tributo no implica que éste no sea el hecho imponible, lo que nos indica es que tiene una naturaleza jurídico tributaria distinta a la impositiva, pues en los tributos que conllevan una contraprestación directa del Estado, la prestación nace como consecuencia de la solicitud y el pago de la contraprestación.

En consecuencia a mi parecer no existe confusión terminológica alguna, pues queda claro que importación y nacionalización son cuestiones distintas: la

${ }^{248}$ AGULLÓ AGÜERO, A. La renta de Aduanas: configuración técnico jurídica y aspectos penales. Ob. Cit. P. 45 «La obligación de pago de los Derechos, si es que existe y no se trata de un pago voluntario, tiene su origen en un imperativo de la ley que señala un momento determinado, un presupuesto de hecho para el nacimiento de la misma, y es dicho presupuesto lo que constituye el hecho imponible (art. 28 L.G.T.) y no un suceso posterior. Un suceso posterior en todo caso podría afectar a la obligación ya nacida si el Ordenamiento le atribuye efectos jurídicos sobre la misma, pero no podría darle origen. Esto no quiere decir claro está que pueda considerarse como hecho imponible cualquier presupuesto anterior a la existencia propiamente dicha de la obligación, sino que es imprescindible que dicho presupuesto cumpla todos los requisitos exigidos al hecho imponible del impuesto en cuestión». GARRE, F. "Importación, Mercancía, Territorio...". En: GARRE, F. MARQUEZ, A. MUÑOZ, F. VICENTE, B. SANCHEZ, I. Estudios aduaneros. Ob. Cit. P.167 «El artículo 28 de la Ley General Tributaria al decir: "el hecho imponible es el presupuesto de naturaleza jurídica o económica fijado por la Ley para configurar cada tributo y cuya realización origina el nacimiento de la obligación tributaria" establece un orden cronológico entre hecho imponible y nacimiento de la obligación tributaria. Se ha de realizar necesariamente el presupuesto fáctico para que nazca la obligación que consiste en el pago del impuesto. Según el artículo 25 de la misma Ley el impuesto se exigirá con arreglo a la verdadera naturaleza jurídica o económica del hecho imponible, aquí, una vez más, aparece bien clara la prelación del hecho imponible. Difícilmente se puede exigir el impuesto con arreglo a la verdadera naturaleza jurídica o económica del hecho imponible, si éste es el último presupuesto que se realiza, al identificarlo con la nacionalización de la mercancía». 
primera constituirá la acción de introducción, y la segunda es la finalidad que se persigue con la introducción de la mercancía, lo que constituye el objeto real del tributo. Así que, siendo el objeto de la introducción de la mercancía al territorio aduanero de la Comunidad la incorporación legal de la misma al circuito económico de la Comunidad, ésta sólo puede darse previa nacionalización de la mercancía.

Por su parte ILDEFONSO SÁNCHEZ para desvirtuar la nacionalización como hecho imponible basa su argumentación en dos supuestos:

a) «La existencia de casos en que se concede la nacionalización de la mercancía y no nace obligación tributaria alguna ni por tanto, se produce hecho imponible. Tal sucede con las mercancías objeto de decomiso por contrabando. El decomiso nacionaliza dichas mercancías sin que exista hecho imponible alguno.

b) la producción de hecho imponible y consiguiente obligación tributaria sin nacionalización. Es el caso de las importaciones temporales" ${ }^{249}$

El segundo de los supuestos lo damos por descontado pues, tal y como señalamos al principio de este apartado, la importación temporal constituye un supuesto distinto al que se comenta ahora. En lo que concierne al primero de los supuestos, relativo a la nacionalización de mercancías decomisadas, habría que partir del concepto de decomiso ${ }^{250}$, el cual debe de entenderse como la

\footnotetext{
${ }^{249}$ SÁNCHEZ, I. "El hecho imponible del impuesto aduanero". Aduanas. 1968, № 174, p. 6

${ }^{250}$ RAMíREZ GUTIÉRREZ, J.A. "Decomiso". En: MÁRQUEZ ROMERO, R. Nuevo diccionario jurídico mexicano, Tomo $D-H$. ${ }^{\text {a }}$ Ed. México: Instituto de Investigaciones Jurídicas, Universidad
} 
pérdida de la propiedad de un bien de un particular a favor del Estado, decretada por una autoridad, aplicada como sanción. El decomiso no genera tributo a la importación pues existe una confusión de derechos en tanto acreedor y deudor recaen sobre una misma persona, extinguiéndose por lo tanto la obligación ${ }^{251}$.

En lo que respecta a las franquicias arancelarias que contempla el Reglamento C.E.E. 918/83, son exenciones a los Derechos de importación que se establecen cuando las condiciones de importación de determinadas mercancías (cantidad, uso y/o destino, etc.), no requieren la aplicación de las medidas habituales de protección de la economía ${ }^{252}$. Estos supuestos son de muy diversa naturaleza ${ }^{253}$, pero con el común denominador de que la Nacional Autónoma de México, 2000, p. 994 «Es la privación de los bienes de una persona, decretada por la autoridad judicial a favor del Estado, aplicada como sanción a una infracción». ${ }^{251}$ Ver al respecto Real decreto de 24 de julio de 1889 por el que se publica el Código Civil. Artículo 1192. "Quedará extinguida la obligación desde que se reúnan en una misma persona los conceptos de acreedor y de deudor».

${ }^{252}$ Ver considerandos primero, segundo y tercero del mencionado Reglamento.

253 Comisión Europea. "Régimen comunitario de franquicias aduaneras", en: Síntesis de legislación de la UE. Bruselas: Oficina de publicaciones Oficiales de la Comisión, Ultima actualización 06.01.2006, Fecha de consulta: 11/09/2015. Disponible en: http://europa.eu/legislation summaries/customs/111002 es.htm. La franquicia de Derechos de importación se refiere a múltiples categorías de mercancías, las cuales pueden enumerarse y resumirse como sigue: Bienes personales: Bienes personales de las personas que trasladan su residencia normal de un tercer país a la $C E$, durante al menos doce meses consecutivos. *Bienes importados con motivo de un matrimonio. Únicamente pueden beneficiarse de esta franquicia las personas que hayan tenido su residencia fuera de la CE durante doce meses consecutivos y que demuestren haber contraído matrimonio.*Bienes personales recibidos en herencia por personas físicas que tengan su residencia en la CE. Mobiliario: Efectos y mobiliario destinados a amueblar una residencia secundaria en territorio comunitario e 
importados por una persona física que tenga su residencia fuera de la CE. *Equipo, material de estudio y demás mobiliario de alumnos o estudiantes que vengan a hacer sus estudios en la Comunidad. Envíos sin valor estimable o sin carácter comercial y bienes de inversión: Envíos sin valor estimable, esto es, de 22 euros como máximo, a excepción de los productos alcohólicos, tabacos, perfumes y colonias. *Envíos sin carácter comercial de un particular de un tercer país a un particular de la Comunidad. El Reglamento fija límites cuantitativos específicos, por envío, para los productos alcohólicos, tabacos, perfumes y colonias. Para los demás productos, el valor máximo es de 45 euros. *Bienes de inversión y de equipo de una empresa que cesa definitivamente sus actividades en un tercer país para establecerse en el territorio de la Comunidad. Estos bienes tienen que haber sido utilizados por la empresa durante doce meses antes del cese de actividad. *Mercancías contenidas en los equipajes personales de los viajeros procedentes de un tercer país, si no tienen carácter comercial. El Reglamento fija límites cuantitativos por viajero en lo que respecta al tabaco, las bebidas alcohólicas y los perfumes. En relación con las demás mercancías, el límite se fija en un valor de 175 euros. Productos agrarios, biológicos, químicos, farmacéuticos y médicos: Productos de la agricultura, la ganadería, la apicultura, la horticultura o la silvicultura obtenidos por ciudadanos europeos. *Semillas, abonos y productos para el tratamiento del suelo y los vegetales importados por agricultores de terceros países para utilizarlos en el territorio de la Comunidad limítrofe de estos países. *Animales y sustancias biológicas o químicas destinados exclusivamente a la investigación. *Sustancias terapéuticas de origen humano y reactivo para la determinación de los grupos sanguíneos y tisulares. ${ }^{*}$ Instrumentos y aparatos destinados a la investigación médica, el establecimiento de diagnósticos o la realización de tratamientos médicos. *Sustancias de referencia para el control de la calidad de los medicamentos. *Productos farmacéuticos importados a la Comunidad con motivo de manifestaciones deportivas internacionales. Otras categorías: Objetos de carácter educativo, científico o cultural, así como instrumentos y aparatos científicos. *Mercancías destinadas a organismos de carácter caritativo y filantrópico y objetos destinados a los invidentes y otras personas discapacitadas. ${ }^{*}$ Condecoraciones y recompensas honoríficas, obsequios recibidos en el marco de las relaciones internacionales, así como mercancías destinadas a los monarcas y Jefes de Estado. *Mercancías importadas con fines de prospección comercial, examen, análisis o ensayos. *Envíos destinados a los organismos competentes en materia de protección de los Derechos de autor o protección de la propiedad industrial o comercial, documentación turística y documentos y artículos diversos" 
importación estará desprovista de todo carácter comercial ${ }^{254}$ y el uso de la mercancía estará restringido únicamente para el importador y el fin específicamente señalado; el importador en ningún momento podrá alquilarlas, prestarlas, entregarlas en prenda o cederlas ${ }^{255}$. En ambos casos se entiende que las mercancías se encuentran al margen del circuito económico de la Comunidad al no estar sujetas a fines de lucro o comercialización. De incumplirse cualquiera de estos principios se entenderá que persiguen un fin comercial y que por lo tanto se incorporan al circuito económico de la Comunidad.

Aun cuando en algunos supuestos de franquicias arancelarias se pudiera presumir que se les concedió el carácter de comunitarias a mercancías que no lo son, es de resaltar las limitaciones de uso a las que están sujetas las mercancías despachadas bajo franquicia, pues en ningún momento gozan de

${ }^{254}$ De acorde con el Reglamento en estudio, en sus artículos 29, 45, 89 «se entenderá por «importaciones desprovistas de todo carácter comercial» las importaciones relativas a envíos que, al mismo tiempo:

— presenten un carácter ocasional;

- comprendan exclusivamente mercancías reservadas para el uso personal o familiar de los destinatarios, sin que su naturaleza o cantidad reflejen intención alguna de carácter comercial;

— sean enviados por el remitente al destinatario sin pago de ninguna clase».

${ }^{255}$ Ver al respecto el artículo $7.2 ; 15.2 ; 24.2 ; 37.2 ; 57.2 ; 58$. Los cuales refieren: «El préstamo, la entrega en prenda, el alquiler o la cesión realizados antes de que transcurra el plazo señalado en el apartado 1, dará lugar a la aplicación de los Derechos de importación correspondientes a las mercancías afectadas, según el tipo en vigor en la fecha del préstamo, entrega en prenda, alquiler o cesión, sobre la base de la especie y el valoren aduana reconocidos o admitidos en esa fecha por las autoridades competentes». 
los Derechos y libertades que goza una mercancía comunitaria, razón por la cual tampoco se cumpliría con esa característica impositiva, quedando por lo tanto al margen de toda tributación, conforme a los supuestos genéricos y especifico. Si bien nos queda claro que la comunitarización de la mercancía no es el elemento objetivo de los Derechos de importación, sí se puede considerar un hecho imponible específico en tanto es una forma de incorporación de la mercancía al circuito económico. La naturaleza jurídico-tributaria en este supuesto, al igual que en el supuesto genérico, no puede ser otra que la de una tasa aun cuando CORTES DOMINGUEZ y el resto de la doctrina contemporánea ${ }^{256}$, ubican este tributo dentro de los impuestos.

En lo expuesto en este epígrafe resulta obvio el rompimiento de este tributo con los elementos esenciales del impuesto, desde la cronológica hasta el principio básico de capacidad contributiva según se analizó en el supuesto genérico. Si bien para CORTES DOMÍNGUEZ no existe intervención alguna por parte de la autoridad en la realización del hecho imponible, aun cuando el mismo señala «la intervención directa y extensa de la Administración, controlando e inspeccionando la actuación de las operaciones aduaneras »257, deja de lado el resultado final de esa inspección y control, consistente en el levante de las mercancías, que no es otra cosa que una certificación por parte de la autoridad, que es lo que autoriza la legítima incorporación de las mercancías al circuito económico de la Comunidad. ¿Quién podría negarle hoy en día el carácter de

\footnotetext{
256 AGULló AGÜERO, BERLIRI, CLAVIJO HÉRNANDEZ, CUTRERA, DI LORENZO, SÁNCHEZ GÓNZALEZ.

${ }^{257}$ CORTES DOMINGUEZ. Ob. Cit.
} 
tasa, al pago que se hace por la obtención de un título o un certificado por parte de la Administración?

En conclusión, nos encontramos en este supuesto con una tasa en la que concurren los dos presupuestos elementales: la utilización de un bien de dominio público que es el circuito económico y, por ende, el mercado común y por otra parte, la prestación de un servicio de forma directa y particularizada, que es la certificación de que la mercancía se encuentra en condiciones de acceder al circuito económico en igualdad de circunstancias que las mercancías comunitarias, cubriendo como pago la proporción del coste económico que tiene para el circuito económico de la Comunidad la incorporación de la mercancía.

\subsubsection{La importación temporal. Naturaleza jurídico-tributaria del cobro por incorporación de la mercancía al régimen de importación temporal.}

Como apuntábamos anteriormente, el segundo supuesto de importación regular previsto por el apartado b) del artículo 44.1 del CAM presenta particularidades que hacían necesario su estudio por separado del supuesto anterior, como veremos en el transcurso de este sub-epígrafe. En primer lugar habría que apuntar que, además de lo previsto en el Código aduanero modernizado y en el Reglamento 2454/93, el régimen de importación temporal está regulado por la Decisión del Consejo 93/329/CEE, que a su vez es un acto de adopción del Convenio Internacional de Estambul relativo a la importación 
temporal de 26 de Junio de 1990 (en lo progresivo será citado únicamente como Convenio de Estambul).

El Código aduanero de 1992, en su artículo 137 describe el régimen de importación temporal de forma sucinta, señalando que «El régimen de importación temporal permitirá el uso en el territorio aduanero de la Comunidad, con exención total o parcial de los Derechos de importación, y sin que estén sometidas a medidas de política comercial, de las mercancías no comunitarias destinadas a ser reexportadas sin haber sufrido modificaciones, a excepción de su depreciación normal causada por el uso que se haga de ellas». El Código aduanero modernizado, en su artículo 162 (sustituto del artículo 137) es más extenso en su descripción del régimen de importación temporal, aglutinando además las condiciones en las que éste se puede otorgar.

Llama especialmente la atención el cambio de expresión que se realizó en la versión en inglés del Código Modernizado: el artículo 137 del CA se refería al régimen como "The temporary importation", en tanto su correspondiente en el Código aduanero modernizado (Artículo 162 CAM), hace referencia al régimen como "The temporary admission". Resulta evidente se trata de una aproximación de la normativa comunitaria a los textos y formas dadas por la Organización Mundial de Aduanas pues si contrastamos la definición dada por el glosario de términos aduaneros de la Organización Mundial de Aduanas al 
concepto de "Temporary Admission" 258 , observaremos una definición análoga a la descripción dada por el artículo 137 del CA, de lo que se debe de comprender por importación temporal. No obstante, a pesar de que el glosario de la Organización Mundial de Aduanas y la legislación aduanera europea consideran ambos términos como sinónimos, es evidente que no es lo mismo “importation,259 que "admission",260, pues la primera se refiere a la entrada de una mercancía de un país al territorio de otro país, en tanto la segunda implica la acción de consentir su entrada. Esta diferencia terminológica nos puede dar mayor luz respecto de la verdadera naturaleza del régimen.

\footnotetext{
${ }^{258}$ World Customs Organization. Glossary Of International Customs Terms. Bruselas, 2006. P. 27 "Temporary Admission": The Customs procedure under which certain goods can be brought into a Customs territory conditionally relieved totally or partially from payment of import duties and taxes; such goods must be imported for a specific purpose and must be intended for re-exportation within a specified period and without having undergone any change except normal depreciation due to the use made of them $\left({ }^{*}\right)$. $\left(^{*}\right)$ Specific Annex G, Chapter 1 of the revised Kyoto Convention.»
}

${ }^{259}$ Black's Law Dictionary.Importation. (17c) The bringing of goods into a country from another country.

${ }^{260}$ Black's Law Dictionary.Admission (ad-mish-ən), n. (15c) 1.Anystatement or assertion made by a party to acase and offered against that party; anacknowledgment that facts are true. 2. Acceptance of a lawyer by the establishedlicensing authority, such as a state bar association, as a member of the practicing bar, usu. after the lawyer passes a bar examinationand supplies adequate character references <admission to the bar>. • The entry of a lawyer on the rolls of an integrated bar, usu. after the fulfillment of two prerequisites: graduating from law school and passing astate bar examination. - Also termed admission to practice law. [Cases: Attorney and Client 4-7.]. ADMISSION, fuente: http://www.thefreedictionary.com/admission, Consultado el 08/11/2011. « $a$. The act of admitting or allowing to enter. $b$. The state of being allowed to enter.

2. Right to enter; access.3. The price required or paid for entering; an entrance fee. 4. A confession, as of having committed a crime. 5. A voluntary acknowledgment of truth. 6. A factorstatementgrantedoradmitted; a concession». 
Fuera de lo gramatical, el primer planteamiento que se nos presenta es saber si la importación temporal con exención parcial es un verdadero hecho imponible o es una exención, en tanto la importación temporal con exención total de Derechos, presenta un matiz totalmente distinto y la controversia radica en si nos encontremos ante verdaderas exenciones o sean más bien supuestos de no sujeción a los derechos arancelarios, al no generar deuda aduanera ${ }^{261}$. Centrándonos ahora en los supuestos de exención parcial, y con el fin de responder a la interrogante de si la importación temporal con exención de derechos es un hecho imponible o una exención, habrá que acudir al concepto de importación temporal recogido en los Códigos, descomponer sus elementos y estudiarlos de manera individual. El concepto de los artículos se refiere a la importación temporal de la siguiente manera:

\begin{tabular}{|c|c|}
\hline $\begin{array}{l}\text { Código Aduanero Reglamento CE } \\
2913 / 1992\end{array}$ & $\begin{array}{l}\text { Código Aduanero Modernizado } \\
\text { Reglamento CE 450/2008 }\end{array}$ \\
\hline $\begin{array}{l}\text { Artículo 137. El régimen de } \\
\text { importación temporal permitirá el uso } \\
\text { en el territorio aduanero de la } \\
\text { Comunidad, con exención total o } \\
\text { parcial de los Derechos de }\end{array}$ & $\begin{array}{l}\text { Artículo 162. Ámbito de aplicación } \\
\text { 1. En el marco del régimen de } \\
\text { importación temporal, las mercancías } \\
\text { no comunitarias destinadas a la } \\
\text { reexportación podrán ser utilizadas en }\end{array}$ \\
\hline
\end{tabular}

${ }^{261}$ El supuesto planteado es un apunte que se realiza, pero que no será tocado en esta tesis por estar fuera del objeto central de la misma, pues el tema daría material suficiente para hacer otro estudio en lo individual. 


\begin{tabular}{|c|c|}
\hline $\begin{array}{l}\text { importación, y sin que estén } \\
\text { sometidas a medidas de política } \\
\text { comercial, de las mercancías no } \\
\text { comunitarias destinadas a ser } \\
\text { reexportadas sin haber sufrido } \\
\text { modificaciones, a excepción de su } \\
\text { depreciación normal causada por el } \\
\text { uso que se haga de ellas. }\end{array}$ & $\begin{array}{l}\text { el territorio aduanero de la Comunidad } \\
\text { con exención total o parcial de } \\
\text { Derechos de importación y sin estar } \\
\text { sometidas a lo siguiente: } \\
\text { a) a otros gravámenes prescritos por } \\
\text { otras disposiciones pertinentes en } \\
\text { vigor; } \\
\text { b) a medidas de política comercial en } \\
\text { la medida en que no prohíban la } \\
\text { entrada de mercancías en el territorio } \\
\text { aduanero de la Comunidad o su salida } \\
\text { de él. }\end{array}$ \\
\hline
\end{tabular}

De la lectura de ambos artículos podemos concretar los siguientes puntos característicos de la importación temporal:

1. En primer lugar el Código de 1992 nos marca que se trata de una permisión, que si bien el Código aduanero modernizado en su versión en castellano no hace mención expresa, recordaremos que en su versión en inglés se refiere al término "Temporaly Admissión", a la que identificábamos con el mismo concepto de permisibilidad.

2. En segundo término, podemos destacar que se restringe el fin de su entrada únicamente al uso de la mercancía, lo que supone una 
diferencia diametral con el hecho genérico y con el despacho a libre práctica, pues existe una limitación del tipo de mercancías que están sujetas a este régimen, además de existir una limitación directa de dominio.

3. La temporalidad de la permisión y de la permanencia de la mercancía en el territorio aduanero de la Comunidad.

4. La exención parcial o total de los derechos de aduana.

5. La no sujeción de las mercancías a las medidas de política comercial.

Bajo estas características estamos en posición de decir que efectivamente se trata de un hecho imponible pues, en primer lugar, de su realización se desprende la obligación de pago de los Derechos arancelarios ${ }^{262} y$, en segundo término, porque no se puede entender como una exención del despacho a libre práctica en tanto goza de características individuales y propias que lo distinguen: principalmente en lo que se refiere a sus restricciones pues en este supuesto, a diferencia del de libre práctica, la importación se restringe única y

\footnotetext{
${ }^{262}$ CLAVIJO HERNÁNDEZ, F. "Tributos aduaneros". En: FERREIRO LAPATZA, J. Curso de Derecho Tributario, parte especial. 18 Ed. Madrid: Marcial Pons, 2002, P. 758 «La introducción de la mercancía en el régimen de importación temporal con exención parcial de los Derechos de importación. (...) el artículo 201.1.b) del Código Aduanero Comunitario considera la inclusión en esas condiciones de la mercancía en el régimen de importación temporal como hecho imponible de los Derechos de aduanas que hace surgir la obligación tributaria por este impuesto». MÁRQUEZ Y MÁRQUEZ, A. Renta de Aduanas, 1aㅡ Ed. Madrid: EDERSA, 1979, P. 219 «El régimen aduanero de importación temporal se configura, como un supuesto de sujeción exento. Con la importación temporal de mercancías se produce una relación jurídico aduanera no impositiva, por el juego de la condición a término (reexportación dentro de plazo) que motiva la exención tributaria, e impide los efectos jurídicos tributarios normales de la realización del hecho imponible aduanero".
} 
exclusivamente al uso de la mercancía sin que pueda sufrir alteración alguna, por lo que está reservado únicamente para mercancías no fungibles.

De igual forma, contrario a lo que sucede con el despacho a libre práctica en el que las mercancías adquieren el carácter de mercancías comunitarias con todos sus Derechos y obligaciones, en el caso de la importación temporal están restringidas a un uso específico, sin poder ser comercializadas en el interior de la Unión, siendo por ello su cobro reducido de los Derechos arancelarios en cuanto no se integran plenamente al circuito económico de la Comunidad.

La otra gran diferencia que encontramos es, lógicamente, la temporalidad pues, en cuanto el régimen de libre práctica es de carácter indefinido, bajo este otro régimen las mercancías podrán estar en el territorio por un periodo determinado $^{263}$ teniendo la obligación el importador, una vez concluido el término, de sacar o de hacer salir la mercancía del territorio comunitario.

\footnotetext{
${ }^{263}$ Código aduanero modernizado. «Artículo 163. Plazo de permanencia de las mercancías en el régimen de importación temporal. 1. Las autoridades aduaneras fijarán el plazo al término del cual las mercancías incluidas en el régimen de importación temporal deberán ser reexportadas o incluidas en un régimen aduanero posterior. Este plazo deberá ser suficiente para que se pueda alcanzar el objetivo del destino autorizado. 2. El plazo máximo de permanencia de las mercancías en el régimen de importación temporal, para el mismo destino y bajo la responsabilidad del mismo titular de la autorización, será de 24 meses, aun cuando el régimen se hubiera ultimado por inclusión de las mercancías en otro régimen especial, a su vez seguido de una nueva inclusión en el régimen de importación temporal. 3. Cuando, en circunstancias excepcionales, el destino autorizado no pueda alcanzarse dentro de los plazos mencionados en los apartados 1 y 2, las autoridades aduaneras, a petición debidamente justificada del titular de la autorización, podrán prorrogar por un tiempo razonable dichos plazos».
} 
La exención parcial de los Derechos arancelarios, como ya comentábamos en párrafos anteriores, es otro de los distintivos de este régimen frente al régimen del despacho a libre práctica, en tanto la mercancía sujeta a importación temporal no se incorpora plenamente al circuito económico de la Comunidad, siendo esta misma la razón por la cual la mercancía se encuentra exenta de las restricciones de la política comercial común.

Como se ha visto, son evidentes las diferencias existentes entre el despacho a libre práctica y el régimen de importación temporal, pero quizás la mayor diferencia la podemos encontrar en la constitución de su hecho imponible. En el apartado correspondiente al hecho imponible genérico concluimos que el cobro de los tributos aduaneros se generaba por la incorporación de las mercancías al circuito económico de la Comunidad; en el caso específico de la importación realizada bajo el despacho a libre práctica esta incorporación se realiza otorgándole el carácter de comunitaria a una mercancía que no lo es, es decir, que puede circular libremente por el circuito económico de la Comunidad en paridad de derechos y obligaciones con las mercancías comunitarias, pero en el caso que tratamos ¿Podríamos hablar de una incorporación limitada al circuito económico de la Comunidad?

Sostenemos en párrafos anteriores que la simple introducción de la mercancía al territorio aduanero comunitario no es ni puede ser considerada el hecho imponible aduanero, ya que existen mercancías que se introducen al territorio y 
no producen deuda aduanera alguna. Ejemplo de ello es la importación temporal de mercancías con exención total de Derechos.

Para encontrar el elemento objetivo del hecho imponible del régimen en estudio, es necesario plantearnos qué hace que una importación temporal esté exenta totalmente de Derechos y otra no.

De acorde al artículo 1 apartado a), del Anexo E del Convenio de Estambul estarán sujetas a importación con suspensión parcial «Las mercancías que se mencionan en los demás Anexos al presente Convenio, pero que no reúnen todas las condiciones previstas para beneficiarse del régimen de importación temporal con suspensión total de los Derechos e impuestos de importación, así como las mercancías que no se mencionan en los demás Anexos al presente Convenio y que se destinen a ser utilizadas temporalmente con fines como la producción o la ejecución de trabajos».

Con este precepto está parcialmente contestada nuestra pregunta, mas no resuelta del todo, pues tendremos que identificar, en primer lugar, de qué mercancías se trata y sus condiciones de sujeción para así determinar en qué casos es aplicable la exención parcial.

El multicitado Convenio de Estambul está conformado por trece anexos de los cuales once describen las mercancías que están sujetas al régimen de 
importación temporal con exención total de Derechos ${ }^{264}$. Con solo revisar los títulos de las mercancías sujetas al régimen es suficiente para percatarse que son mercancías destinadas a su utilización en espacios, tiempos, personas y fines específicos fuera de toda actividad comercial o de lucro, es decir, fuera del circuito económico de la Comunidad. No podrán ser sujetas de exención las mercancías que no sean destinadas al fin específico que fue declarado para su importación ${ }^{265} \mathrm{y}$, aquellas cuyo volumen sea mayor del requerido para la consecución de los fines previstos para su importación y que el sobrante de la mercancía pueda ser sujeto de comercialización. Por lo que podemos resumir que serán sujetas al gravamen cuando de una u otra forma se incorporen al circuito económico de la Comunidad. En términos similares a los nuestros se expresa la Comunidad Andina al entender: « El principio que rige la imposición

${ }^{264}$ Anexo B.1: relativo a las mercancías destinadas a exhibiciones o exposiciones, ferias, reuniones o acontecimientos similares. Anexo B.2: relativo al equipo profesional. Anexo B.3: relativo a contenedores, paletas, envases, muestras y otras mercancías importadas en relación con una operación comercial. Anexo B.4: relativo a las mercancías importadas en relación con una operación de fabricación. Anexo B.5: relativo a las mercancías importadas con fines educativos, científicos o culturales. Anexo B.6: relativo a los efectos personales de los viajeros y mercancías importadas con fines deportivos. Anexo B.7: relativo al material de publicidad turística. Anexo B.8: relativo a las mercancías importadas como tráfico fronterizo. Anexo B.9: relativo a las mercancías importadas con fines humanitarios. Anexo C: relativo a los medios de transporte. Anexo D: relativo a los animales. Si se desea ver una descripción más amplia de estos anexos puede consultarse a: GORMLEY, L.W. EU law of free movement of goods and customsUnion. $1^{\circ}$ Ed. New York: Oxford University Press, 2009, P. 258 - 270. LYONS, T. EC Customs Law. $1^{\circ}$ Ed.New York: Oxford UniversityPress, 2005 (Segunda impresion), P. 331 337.

${ }^{265}$ Dentro de los cuales se engloba el caso específico de: "que se destinen a ser utilizadas temporalmente con fines como la producción o la ejecución de trabajos" que cita el antes referido artículo $1^{\circ}$ del Anexo E. 
de Derechos de aduana, que tiene su origen en las legislaciones nacionales basada en el Convenio de Kyoto, prevé el cobro de Derechos de importación sólo cuando las mercancías no originarias entran efectivamente en el ciclo económico de los Países Miembros de la Comunidad Andina. Por consiguiente, la aplicación de Derechos de importación a mercancías cuyo destino final es ser reexportadas, tras ser utilizadas transitoriamente de acuerdo con su finalidad dentro del territorio aduanero.

Sin embargo, debe evitarse que la importación temporal de mercancías pueda causar un perjuicio económico a los fabricantes de mercancías similares dentro de la Comunidad o a los usuarios de mercancías no originarias despachadas en libre práctica» ${ }^{266}$.

El elemento objetivo del hecho imponible sigue siendo el mismo que en el supuesto genérico y que en el despacho a libre práctica, "la incorporación de la mercancía en el circuito económico de la Comunidad", por lo que la naturaleza jurídico-tributaria sería la misma, en un principio. El tipo aplicable va en proporción al grado de utilización del circuito económico pero, como ya hemos venido apuntando en párrafos anteriores, encontramos un rasgo muy marcado en este régimen que es lo referente a la autorización previa ${ }^{267}$. Esto implica una

${ }^{266}$ SECRETARÍA GENERAL COMUNIDAD ANDINA. "Comunidad Andina - Unión Europea análisis de regímenes y aspectos aduaneros". Documentos informativos. 24 de agosto de 2009. P. 34

${ }^{267}$ Además del ya expuesto artículo 162 del CAM, el Reglamento de aplicación del Código Aduanero, hace continua referencia al trámite y solicitud de autorización, ver por ejemplo: Arts. $498,500,501,511$. 
actuación de autoridad a fin de que se pueda llevar a cabo el hecho imponible, por lo que al consistir en un acto de permisión es una contraprestación directa de la autoridad que otorga al importador.

Sin embargo, como apunta la profesora AGULLÓ AGÜERO, «En el caso del gravamen aduanero, el establecimiento del mismo resulta obvio que responde a un deseo de gravar las mercancías extranjeras que se introducen en el interior para equipararlas en el mercado a los productos nacionales; de ningún modo por tanto, para financiar una actividad de la Administración o de la Aduana en particular» ${ }^{268}$, lo que nos regresa a nuestra posición genérica de considerarla una tasa por la utilización de un bien de dominio público.

268 AGULLÓ AGÜERO, A. La renta de Aduanas: configuración técnico jurídica y aspectos penales. Ob. Cit. P. 60. 


\section{CAPÍTULO 3. LA DEUDA ADUANERA GENERADA POR IRREGULARIDADES E}

INCUMPLIMIENTO.

El artículo 79 del Código Aduanero de la Unión (CAU) (Anterior 46 del Código Aduanero Modernizado «CUM») regula lo que denomina: "Deuda aduanera nacida por incumplimiento". Este artículo agrupa los supuestos anteriormente contenidos en los artículos 202, 203, 204 y 205 del Código Aduanero. Para su estudio hemos decidido dividir los supuestos contemplados en este artículo en dos grupos, un primer grupo al que denominamos «nacimiento de la deuda aduanera por importación irregular», y otro respetando el nombre que da el Código Aduanero de la Unión «nacimiento de la deuda aduanera por incumplimiento». La división obedece que el primer grupo propuesto, trata de supuestos que marcan una acción directa de contravención a la norma, al incorporar la mercancía al circuito económico de la Comunidad eludiendo el control de las aduanas y por consecuencia el pago correspondiente de los derechos, es por ello que se titulan irregulares. En tanto el segundo grupo habla de omisiones a la norma, pues la mercancía ya se había incorporado de forma regular y el cobro nace por un incumplimiento de las formalidades o fines a los que se sujetaba la incorporación ${ }^{269}$.

\footnotetext{
${ }^{269}$ STJCE de fecha11 de julio de 2013, asunto C-273/12, en el caso: Directeur général des douanes et droits indirects, Chef de l'agence de poursuites de la Direction nationale du renseignement et des enquêtes douanières vs Harry Winston SARL. «27. Tampoco el artículo 204, apartado 1, letra a), del Código aduanero resulta de aplicación al presente asunto, puesto
} 
Es necesario recalcar en este rubro que la Unión Europea carece de facultades sancionadoras, y que son los Estados miembros los encargados de regular el derecho sancionador ${ }^{270}$; El artículo 42 del CAU establece expresamente que «Cada Estado miembro establecerá sanciones en caso de incumplimiento de la legislación aduanera comunitaria. Dichas sanciones serán efectivas, proporcionadas y disuasorias».

No obstante que aun cuando en la mayoría de los supuestos a estudiar en este capítulo se tratan de hechos que en la legislación nacional consideran como ilícitos, como ya se dijo en el capítulo anterior el nacimiento de la obligación tributaria aduanera es independiente de las sanciones que se generen ${ }^{271}$ y así

que, como es preciso señalar, se refiere al nacimiento de una deuda aduanera de importación en casos de incumplimiento de cualquiera de las obligaciones a que queda sujeta una mercancía sometida a derechos de importación como consecuencia de la utilización del régimen aduanero en el que se encuentre, en casos distintos de los contemplados en el artículo 203 del Código. En efecto, los ámbitos de aplicación de los artículos 203 y 204 del Código aduanero están claramente diferenciados: el primero contempla comportamientos que tienen como resultado la sustracción de la mercancía a la vigilancia aduanera y el segundo tiene por objeto los incumplimientos de las obligaciones y de los requisitos ligados a los distintos regímenes aduaneros».

270 DURBAN ACIEN, J. "Sistema aduanero". En: Aduanas Informa. Núm. 77, abril - junio 1998.

P. 11 «La normativa aduanera comunitaria no entra siquiera a regular los aspectos sustantivos: no tipifica $o$ no define como infracciones al régimen aduanero determinadas acciones $u$ omisiones de los operadores de comercio exterior, ni por tanto estableces sanciones en este régimen".

${ }^{271}$ LYONS, T. EC Customs Law. Ob. Cit. P.377 «A customs debt is, nevertheless, deemed to have been incurred for the purposes of criminal law, where the criminal law of a Member State uses customs duties as the basis for determining penalties, or where the existence of a customs debt provides grounds for taking criminal proceedings». 
lo deja en claro el artículo 83 del $\mathrm{CAU}^{272}$, el cual establece como requisito básico para el nacimiento de la deuda aduanera que se traten de mercancías que, por su propia naturaleza y sus características particulares, puedan comercializarse lícitamente e integrarse en el circuito económico; o en el caso de ser ilícitas, compitan con productos objeto de operaciones realizadas en el marco de un circuito legal ${ }^{273}$. «Además, según reiterada jurisprudencia, el

$\overline{272 ~ « A r t i ́ c u l o ~ 50 . ~ P r o h i b i c i o n e s ~ y ~ r e s t r i c c i o n e s . ~ 1 . ~ L a ~ d e u d a ~ a d u a n e r a ~ d e ~ i m p o r t a c i o ́ n ~ o ~ d e ~}$ exportación nacerá incluso cuando se refiera a mercancías sujetas a medidas de prohibición o restricción de importación o de exportación de cualquier tipo.

2. No obstante, no nacerá ninguna deuda aduanera en ninguno de los siguientes casos:

a) por la introducción ilegal en el territorio aduanero de la Comunidad de monedas falsificadas;

b) por la introducción en el territorio aduanero de la Comunidad de estupefacientes y sustancias psicotrópicas distintos de los estrictamente supervisados por las autoridades competentes con vistas a su utilización para fines médicos y científicos.

3. A efectos de las sanciones aplicables a las infracciones aduaneras, se considerará que ha nacido una deuda aduanera cuando, con arreglo a la legislación de un Estado miembro, los derechos de aduana o la existencia de una deuda aduanera suministren la base para determinar las sanciones».

${ }^{273}$ Ver al respecto la Sentencia del TJCE de fecha 29 de Junio de 2000, asunto C-455/98, en el caso:Tullihallitus contra Kaupo Salumets y otros. Apartados 17 al 19. «No obstante, los Gobiernos finlandés, helénico e italiano, así como la Comisión, invocan otras sentencias en las que el Tribunal de Justicia ha declarado que se devenga normalmente el IVA cuando las mercancías fraudulentamente comercializadas compiten con productos objeto de operaciones realizadas en el marco de un circuito legal. Es así con respecto a los perfumes falsificados (sentencia de 28 de mayo de 1998, Goodwin y Unstead, C-3/97, Rec. p. I-3257), la explotación de juegos de azar ilícitos (sentencia de 11 de junio de 1998, Fischer, C-283/95, Rec. p. I-3369) y la exportación en condiciones ilegales de sistemas informáticos (sentencia de 2 de agosto de 1993, Lange, C-111/92, Rec. p. I-4677). Concretamente, del apartado 16 de esta última sentencia se desprende que el principio de neutralidad fiscal se opone efectivamente en materia de percepción del IVA a una diferenciación generalizada entre transacciones lícitas e 
principio de neutralidad fiscal se opone a una diferenciación generalizada entre transacciones lícitas e ilícitas. De ello se desprende que la calificación de censurable comportamiento no implica, en sí misma, una excepción a la sujeción al impuesto, sino que tal excepción sólo resulta de aplicación en situaciones específicas en las que, por las características concretas de determinadas mercancías o prestaciones, queda excluida toda competencia entre un sector económico licito y un sector ilícito ${ }^{274}$

Es por ello que en este estudio nos centraremos al análisis de los supuestos desde la perspectiva estrictamente tributaria comunitaria, dejando de lado la materia sancionatoria.

ilícitas, excepto en los casos en que, por las características específicas de determinadas mercancías, queda excluida toda competencia entre un sector económico lícito y otro ilícito.

Según dichos Gobiernos y la Comisión, los estupefacientes y la moneda falsa son productos que no pueden introducirse en el circuito económico debido a su carácter intrínseco de mercancías ilícitas. No obstante, el alcohol etílico no reviste tal carácter, aunque su importación y su venta estén sujetas a autorización en Finlandia. En efecto, podría venderse en condiciones ilícitas mucho menos caro que las bebidas alcohólicas lícitas y con un objetivo de consumo idéntico. En estas circunstancias, consideran que el alcohol importado de contrabando compite plenamente con los productos alcohólicos de venta legal, por lo que origina una deuda aduanera y fiscal. En efecto, en las sentencias mencionadas en el apartado anterior, el Tribunal de Justicia interpretó en un sentido muy restrictivo las excepciones al principio de la neutralidad fiscal».

${ }^{274}$ Ibidem 


\subsection{EL NACIMIENTO DE LA DEUDA ADUANERA POR IMPORTACIÓN IRREGULAR.}

Analizaremos en este epígrafe los supuestos que regulaban antiguamente los artículos 202 y 203 del Código Aduanero, hoy contenidas en el artículo79.1 del Código aduanero de la Unión; es decir, lo relativo a:

- Introducción irregular en el territorio aduanero de la Comunidad de una mercancía sujeta a derechos de importación;

- Introducción irregular en el resto del territorio aduanero de la Comunidad de una mercancía sujeta a derechos de importación, que se encuentre en una zona franca o depósito franco; y

- Sustracción de la vigilancia aduanera de una mercancía sujeta a derechos de importación.

\subsubsection{La introducción irregular}

El Código aduanero en el artículo 202.1 contemplaba como introducción irregular «cualquier introducción que viole las disposiciones de los artículos 38 a 41 y del segundo guion del artículo $177 »^{275}$. Texto que ya no aparece de forma literal en el artículo 46 del Código aduanero modernizado ${ }^{276}$ y 79 del

\footnotetext{
${ }^{275}$ Ver cuadro anexo con los artículos 38 a 41 del Código aduanero y sus equivalencias en el Código aduanero modernizado.

${ }^{276}$ Artículo 46 del CAM «Deuda aduanera nacida por incumplimiento.1. Respecto de las mercancías sujetas a derechos de importación, nacerá una deuda aduanera de importación por incumplimiento de alguna de las siguientes circunstancias:
} 
Código aduanero de la Unión ${ }^{277}$, los cuales conjugan el contenido del texto anterior, sin hacer referencia específica a artículo alguno del código, describiendo de manera general los incumplimientos que generan el nacimiento de la deuda aduanera.

Siguiendo como referencia los artículos señalados por el artículo 202.1 del Código aduanero comunitario, en correspondencia con el Código aduanero modernizado y de la Unión, podemos establecer de manera general que las violaciones o incumplimientos a que se refiere la normativa son generadas por contravenir disposiciones relativas: a la vía de ingreso de las mercancías; al traslado de la mercancías al lugar apropiado (aduana, zona franca o cualquier lugar señalado por la autoridad aduanera), puesta a disposición de las mercancías ante las autoridades aduaneras; la presentación de las declaraciones correspondientes, y de igual forma en lo relativo a la incorporación de mercancías de zonas francas al territorio de la comunidad ${ }^{278}$.

a) una de las obligaciones establecidas en la legislación aduanera relativa a la introducción de mercancías no comunitarias en el territorio aduanero de la Comunidad, a la retirada de estas de la vigilancia aduanera o a la circulación, transformación, depósito, importación temporal o disposición de tales mercancías en ese territorio;

b) una de las obligaciones establecidas en la legislación aduanera relativa al destino final de las mercancías dentro del territorio aduanero de la Comunidad;

c) una condición que regule la inclusión de mercancías no comunitarias en un régimen aduanero o la concesión, en virtud del destino final de las mercancías, de una exención de derechos o de una reducción del tipo de los derechos de importación».

${ }^{277}$ El texto es idéntico al del artículo 46 del CAM referido anteriormente.

278 De igual forma PELECHA ZOZAYA, ubica estos supuestos generadores, abarcando además el resto de supuestos que engloba el artículo 46 del Código aduanero modernizado. 
Cada uno de los artículos contemplados por el 202.1 del Código Aduanero, representan supuestos independientes que deben ser estudiados de forma separada, en tanto, la violación de alguno de ellos en lo individual, supone una introducción irregular de la mercancía, sin importar que algunos de estos presupuestos sean consecutivos o derivados uno del otro ${ }^{279}$. En consecuencia el desarrollo de este epígrafe atenderá a la secuencia marcada por la propia

Existiendo en su exposición algunos matices que iremos puntualizando a lo largo de este epígrafe. PELECHA ZOZAYA, F. Fiscalidad sobre el comercio exterior: el derecho aduanero tributario. 1ㄹ Ed. Madrid: Marcial Pons, 2009, P.37 «Es decir, la «deuda aduanera por incumplimiento"; en otras palabras, la deuda aduanera de importación que se origina porque el interesado incumple la obligación de declarar la entrada de mercancías no comunitarias en el territorio aduanero de la Comunidad, incumple la obligación de poner tales mercancías bajo el control de las autoridades aduaneras hasta que presente la correspondiente declaración, incumple la obligación de realizar determinadas cosas con las mercancías importadas, condición en base a la cual pudo importar tales mercancías acogiéndose a determinadas exenciones o bonificaciones por lo que respecta al $A A C$, etc".

${ }^{279}$ STJCE de 3 de marzo de 2005, asunto C-195/03, en el caso: Ministerie van Financiën Vs MerabiPapismedov y otros. Apartados 25 y 26. «Varias disposiciones del Código aduanero permiten delimitar el concepto de «introducción irregular». Es el caso, como ha señalado el Gobierno belga acertadamente, del artículo 202 de dicho Código que la define como cualquier introducción que infrinja lo dispuesto en los artículos 38 a 41 y 177, párrafo primero, segundo guión, del mismo Código, de una mercancía sujeta a derechos de importación, ya sea en el territorio aduanero de la Comunidad, o bien en otra parte de este territorio, cuando se encuentre en una zona franca o en un depósito franco. En consecuencia, constituye una introducción irregular la importación de mercancías que no observe las posteriores etapas previstas en el Código aduanero. En primer lugar, según el artículo 38, apartado 1, de dicho Código, las mercancías que se introduzcan en el territorio aduanero de la Comunidad deben ser trasladadas sin demora, bien a la aduana designada, bien a una zona franca. En segundo lugar, con arreglo al artículo 40 de dicho Código, cuando las mercancías lleguen a la aduana, deben ser presentadas en esa oficina. La presentación en aduana de la mercancía se define, en el artículo 4, punto 19, del mismo Código, como la comunicación a las autoridades aduaneras, en la forma requerida, de que las mercancías están presentes en esa oficina o en cualquier otro lugar designado o autorizado». 
norma y al estudio individualizado de cada uno de los supuestos desde una perspectiva netamente casuística, pues por desgracia no existen muchos estudios al respecto, y la poca bibliografía existente se constriñe la más de las veces a la transcripción de los artículos del Código ${ }^{280}$.

\subsubsection{La introducción de la mercancía por las vías determinadas.}

El artículo 135. 1 del CAU, como sus predecesores (38.1 del CA y 92.1 del CAM) establecen como obligación la entrada de la mercancía utilizando la vía determinada por las autoridades aduaneras, es decir a través de los puntos fronterizos reconocidos por la Unión para tales efectos y que se encuentran bajo vigilancia de las autoridades aduaneras.

De una interpretación literal se desprendería que con el simple paso de la mercancía por un punto fronterizo distinto al autorizado por las autoridades aduaneras se actualizaría el supuesto de incumplimiento, naciendo con ello la deuda aduanera; pues la entrada de la mercancía por un punto distinto del legalmente establecido constituye por sí mismo una violación de carácter formal, en la que es presumible la intención de que la mercancía eluda el control de las aduanas. Postura que argumentó el Gobierno Belga en el caso C-195/03, asunto: Ministerie van Financiën Vs Merabi Papismedov y otros ${ }^{281}$.

\footnotetext{
${ }^{280}$ BERR, C. y TRÉMEAU, H. Le droit douanier. Ob. Cit. P. 216. LASOK, D. The Trade and Customs Law of the European Union. Ob. Cit. P. 354. LYONS, T. EC Customs Law. Ob. Cit. P. 379.

${ }^{281}$ En el apartado 23 de la STJCE de 03 de Marzo de 2005, del caso referido se señala: « $A$ la luz del artículo 202 del Código aduanero, que define la introducción irregular de mercancías como la que se efectúa infringiendo los artículos 38 a 41 y 177, párrafo primero, segundo
} 
Por su parte el Abogado General, SR. PAOLO MENGOZZI considera dicha interpretación como restrictiva, pues en su opinión "En el caso de introducción de mercancías a través de la denominada «frontera verde», es decir, en un punto fronterizo no vigilado, el momento en que se materializa la irregularidad será aquel en el que se manifiesta la intención de no llevar las mercancías a la administración de aduanas' ${ }^{\prime 282}$. Bajo este planteamiento, se deriva el nacimiento de la deuda aduanera al incumplimiento de la presentación de las mercancías en aduanas ${ }^{283}$, lo que es entendible si partimos de la falta de potestades sancionatorias de la Unión, y de que el elemento objetivo de la tributación es la incorporación de la mercancía al circuito económico de la comunidad. Pues como hemos analizado anteriormente, el simple paso de la

guión, del mismo Código, el Gobierno belga sostiene que tiene lugar una introducción regular en el territorio aduanero de la Comunidad cuando se cumplen dichas disposiciones, es decir, cuando la mercancía ha cruzado una de las fronteras exteriores y ha sido trasladada a los servicios aduaneros. Considera que, dado que la obligación de presentar una declaración sumaria, como la prevista en los artículos 43 y siguientes de dicho Código, no está comprendida entre aquellas cuyo incumplimiento puede suponer una introducción irregular de mercancías en dicho territorio, la mención de una denominación comercial errónea de las mercancías en tal documento en nada cambia el carácter regular de su introducción en el referido territorio. A su juicio, por lo tanto, la introducción irregular equivale a la importación clandestina a través de vías o de pasos fronterizos no reconocidos". En el mismo sentido BERR, C,J. y TRÉMEAU, H. Le droit douanier Communautaire et national. Ob. Cit. P. 442 «La contrebande s'entend ainsi d'un certain nombre d'agissements précisés dans l'article 417, $C D$, agissements dont on se contentera d'énumérer quelques exemples : franchissement irrégulier des limites du territoire douanier en dehors des routes légales ou par les routes légales fermées au trafic international».

${ }^{282}$ CONCLUSIONES DEL ABOGADO GENERAL, SR. PAOLO MENGOZZI. Presentadas el 4 de noviembre de 2008. Asunto C-459/07. Caso: Veli Elshani Vs. Hauptzollamt Linz.

283 En ese mismo sentido lo establece la ya citada STJCE de 3 de marzo de 2005, asunto C195/03, en el caso: Ministerie van Financiën Vs Merabi Papismedov y otros. Apartados 25 y 26. 
línea fronteriza no es, ni puede ser considerado como hecho imponible alguno, al carecer de todo elemento económico que revele capacidad contributiva objetiva o subjetiva, por lo que el cobro que se hiciera por ese supuesto tendría indubitablemente el carácter de sanción, saliendo por lo tanto del ámbito competencial de la Comunidad Europea.

Aun cuando el riesgo ${ }^{284}$ es un factor determinante para el nacimiento de la deuda aduanera, el legislador comunitario considera que el simple paso de la línea fronteriza no entraña un riesgo de incorporación de la mercancía al circuito económico de la comunidad, no obstante que la introducción se realice por un cruce fronterizo no autorizado, y de que la mercancía se encuentre de facto en territorio comunitario, "debe considerarse que han sido objeto de una «introducción irregular» en ese territorio en el sentido del artículo 202 del Código aduanero las mercancías que, habiendo cruzado la frontera terrestre exterior de la Comunidad, se encuentran en dicho territorio más allá de la primera oficina aduanera, sin haber sido conducidas hasta allí y sin que hayan sido presentadas en aduana, con el resultado de que las autoridades

\footnotetext{
${ }^{284}$ Me parece interesante ver la definición de riesgo que da el propio Código Aduanero Modernizado. "Artículo 4 Definiciones. A los efectos del presente código, se entenderá por: 7) «riesgo»: la probabilidad de que se produzca un hecho en relación con la entrada, salida, tránsito, transferencia o destino final de las mercancías que circulen entre el territorio aduanero de la Comunidad y otros países o territorios situados fuera de aquel, o con la presencia de mercancías que no tengan estatuto comunitario, que lleve a cualquiera de los resultados siguientes: a) impedir la correcta aplicación de disposiciones comunitarias o nacionales; b) comprometer los intereses financieros de la Comunidad y de sus Estados miembros; c) constituir una amenaza para la seguridad y protección de la Comunidad y de sus residentes, para la salud pública, la sanidad animal o la fitosanidad, para el medio ambiente o para los consumidores;”
} 
aduaneras no han recibido comunicación del hecho de la introducción de esas mercancías por parte de las personas responsables de la ejecución de esa obligación,285 . Bajo este razonamiento se asemejaría la zona fronteriza ${ }^{286}$ con una zona franca sin serlo propiamente, ya que en tanto las mercancías permanezcan en esta zona "no generan deuda aduanera", pues en caso de ser descubiertas, antes de llegar a la primer aduana serán aprehendidas y decomisadas extinguiendo con ello la deuda aduanera ${ }^{287}$.

Por lo que en conclusión, la introducción de la mercancía por un paso no autorizado no constituye por sí misma un hecho generador de deuda aduanera, pues como ya hemos venido repitiendo "una «introducción irregular» existe únicamente después de que la persona haya abandonado el puesto fronterizo o

${ }^{285}$ STJCE de 02 de abril de 2009, asunto 459/07, en el caso: Veli Elshani vs Hauptzollamt Linz. Apartado 26.

${ }^{286}$ WCO glossary, Ob. Cit. «Frontier Zone: An area of the Customs territory adjacent to the land frontier, the extent of which is determined in national legislation and whose limitsserve to distinguish frontier traffic from other traffic. Note This term is defined in Annexes B.8 and D to the Istanbul Convention».

287 STJCE de 02 de abril de 2009, asunto 459/07, en el caso: Veli Elshani vs Hauptzollamt Linz. Apartado 38. "A la luz de las consideraciones anteriores, se ha de responder a la primera cuestión planteada que los artículos 202 y 233, párrafo primero, letra d), del Código aduanero deben interpretarse en el sentido de que, para causar la extinción de la deuda aduanera, el decomiso de mercancías introducidas irregularmente en el territorio aduanero de la Comunidad debe producirse antes de que tales mercancías pasen la primera oficina aduanera situada en el interior de ese territorio». 
haya manifestado de modo inequívoco su intención de no declarar las mercancías ante las autoridades aduaneras ${ }^{, 288}$.

Conclusión que habría que matizar pues aun lo descrito anteriormente puede surgir deuda aduanera, pues como recordaremos el artículo 124.2 del CAU, establece enfáticamente que: «No obstante, en los casos mencionados en el apartado 1, letra e), se considerará que la deuda aduanera, no se ha extinguido, a efectos de las sanciones aplicables a las infracciones aduaneras, cuando, con arreglo al Derecho de un Estado miembro, los derechos de importación o de exportación o la existencia de una deuda aduanera constituyan la base para determinar las sanciones». Por lo que sí un Estado miembro estableciera sanciones específicas a la introducción de la mercancía por un paso no autorizado, tomando como base los derechos de aduana, nacería por ende una deuda aduanera, pues como vimos la sanción nace de manera autónoma al derecho de pagar la deuda aduanera.

\subsubsection{La obligación de traslado de la mercancía al lugar apropiado.}

Atinadamente el artículo 135 del Código Aduanero de la Unión fue titulado "Traslado al lugar apropiado"; en esencia, trata de la primera exigencia para una importación legal: el que la mercancía una vez que haya entrado al territorio aduanero de la comunidad sea llevada a la aduana o zona franca correspondiente. La finalidad de esta última obligación, que corresponde al

\footnotetext{
${ }^{288}$ Conclusiones del Abogado General, Asunto C-459/07 Ob. Cit., Apartado 40. Criterio secundado en la sentencia del mismo asunto, con fecha de 02 de abril de 2009, en su apartado 26.
} 
responsable de la introducción o al que se hace cargo del transporte, consiste en garantizar que se informe a las autoridades aduaneras no sólo de la llegada de las mercancías, sino también de todos los datos pertinentes relativos al tipo de artículo o de producto de que se trate, así como a la cantidad de tales mercancías. En efecto, esta información permitirá la identificación correcta de aquéllas, con vistas a su clasificación arancelaria y, en su caso, al cálculo de los derechos de importación.

Entenderemos que una mercancía no ha cumplido estas disposiciones, es decir, que se ha devengado la deuda aduanera por incumplimiento, cuando la mercancía se ha internado en el territorio comunitario más allá de la primera oficina aduanera sin haber sido conducida hasta allí y sin que haya sido presentada en aduana, con el consiguiente desconocimiento de las autoridades aduaneras $^{289}$.

La construcción del hecho imponible prevista en el artículo 79.1 a) del CAU, trata en todo momento del incumplimiento de obligaciones de carácter formal, sin dejar ver su naturaleza tributaria, lo que no implica necesariamente que

${ }^{289}$ STJCE de 29 de abril de 2010, asunto C-230/08, en el caso: Dansk Transport og Logistik vs Skatteministeriet. Apartado 49. "las mercancías que, habiendo cruzado la frontera terrestre exterior de la Comunidad, se encuentran en dicho territorio más allá de la primera oficina aduanera, sin haber sido conducidas hasta allí y sin que hayan sido presentadas en aduana, con el resultado de que las autoridades aduaneras no han recibido comunicación del hecho de la introducción de esas mercancías por parte de las personas responsables del cumplimiento de esa obligación». STJCE de 02 de abril de 2009, asunto 459/07, Ob. Cit. Apartado 25. «la introducción irregular de mercancías se consuma desde que pasan la primera oficina aduanera situada en el interior del territorio aduanero de la Comunidad sin que hayan sido presentadas en ella». 
carezca de ella, pues como recordaremos lo visto en el capítulo 2.1, el elemento objetivo común en los supuestos que generan deuda aduanera, es la integración al circuito económico de la comunidad de mercancías extracomunitarias. La internación de manera irregular de la mercancía más allá de la primera oficina de aduanas, presupone una posible incorporación de estas en el circuito económico de la Comunidad, pues escapan al control de las autoridades aduaneras presuponiendo un riesgo mayor de que puedan integrarse al circuito económico ${ }^{290}$.

A primera vista la construcción del hecho imponible nos hace cuestionarnos su posible identificación como "gravamen fiscal", en tanto es evidente que estamos en presencia de un supuesto que nace por la contravención de una norma que constituye un ilícito tipificado como tal en las leyes de algunos Estados miembros ${ }^{291}$. Sin embargo, como hemos venido comentando existe

\footnotetext{
${ }^{290}$ STJCE de 02 de abril de 2009, asunto 459/07, Ob. Cit. Aparatos 32 y 33. «32. A este respecto, debe señalarse que la presencia en el territorio aduanero de la Comunidad de mercancías introducidas irregularmente entraña, en sí misma, un riesgo muy elevado de que tales mercancías acaben integradas en el circuito económico de los Estados miembros y de que, una vez que esas mercancías hayan pasado la zona en la que se encuentra la primera oficina aduanera situada en el interior de dicho territorio, haya menos posibilidades de que sean descubiertas de manera fortuita por las autoridades aduaneras en el marco de controles imprevistos. 33. Es, en efecto, en las oficinas aduaneras, que se hallan emplazadas estratégicamente en los puntos de entrada situados en las fronteras exteriores, donde las autoridades pueden ejercer mejor un control intensivo de las mercancías que entran en el territorio aduanero de la Comunidad, para evitar tanto la competencia desleal hecha a los productores comunitarios como la pérdida de ingresos fiscales que implican las importaciones fraudulentas».

${ }^{291}$ MISSIONÁRIO,T. "Divida aduaneira". En: NUNO DA ROCHA, A. (Coordinador). Direito Aduaneiro das Comunidades Europeias: na perspectiva Uniao Europeia-Estudos. Braga: Barbosa \& Xavier, 1992, p. 265 «Para efeitos de constituiçao da dívida aduaneira na
} 
autonomía absoluta entre el ilícito tributario denominado contrabando y la deuda aduanera, desde su fuente hasta su extinción, pues indistintamente del surgimiento y represión del ilícito, surge la deuda aduanera. Además, la acción penal no se suspende por el pago de la deuda o el decomiso posterior de la mercancía ${ }^{292}$, ya que atienden a naturaleza y jurisdicciones distintas, pues la deuda aduanera como lo hemos expresado en este trabajo, es materia exclusiva de la Unión, en tanto la represión del ilícito y su tipificación siguen estando en la jurisdicción del Estado tal y como lo contempla el artículo 42.1

importaçao, a introduçao irregular é qualquer introduçao de uma mercadoria no território aduaneiro comunitáiro sem ter sido, previamente, a presentada ás alfándegas e se for caso disso, colocada em deposito provisório. Para além de a introduçao irregular configurar, no direito interno, uma infracçao fiscal aduaneira, punivel enquanto tal, a regulamentaçao comunitaria impoe a obrigaçao de pagamento dos direitos de importaçao a que estariam sujeitas as mercadorias, em consequencia da sua integraçao de fecto na economia comunitária, legalmente presumida».Verbigracia: España. Ley Orgánica 12/1.995, de 12 de diciembre, de Represión del Contrabando. Artículo 2 «Tipificación del delito. 1. Cometen delito de contrabando, siempre que el valor de los bienes, mercancías, géneros o efectos sea igual o superior a 3.000.000 de pesetas, los que: a) Importen o exporten mercancías de lícito comercio sin presentarlas para su despacho en las oficinas de aduanas o en los lugares habilitados por la Administración aduanera. La ocultación o sustracción dolosa de cualquier clase de mercancías a la acción de la Administración aduanera dentro de los recintos o lugares habilitados equivaldrá a la no presentación». Artículo 10. "Valoración de los bienes. 2. Si se trata de mercancías no comunitarias, por aplicación de las normas que regulan la valoración en aduana. El valor resultante se incrementará con el importe de los tributos exigibles a su importación».

292 Ver al respecto la multicitada STJCE de 02 de abril de 2009, asunto 459/07, Ob. Cit. En su apartado 34, que a la letra dice: «34. De lo antedicho se desprende que el decomiso de mercancías introducidas en el territorio aduanero de la Comunidad infringiendo los artículos 38 a 41 del Código aduanero, que tiene lugar más allá de la primera oficina aduanera situada en el interior de ese territorio y que prácticamente se produce por casualidad, no puede suponer la extinción de la deuda aduanera en el sentido del artículo 233, párrafo primero, letra d), del Código aduanero» 
del Código Aduanero de la Unión ${ }^{293}$, por lo cual no se cumple con el requisito básico del gravamen fiscal: "retirar una prohibición por efectos del pago de una suma determinada", pues el ilícito se sigue persiguiendo indistintamente del pago y de que una vez cubierta la deuda aduanera la mercancía sea considerada mercancía comunitaria sin necesidad de ser despachada a libre práctica $^{294}$, como lo contempla el artículo 866 del Reglamento del 2454/93 ${ }^{295}$.

\footnotetext{
${ }^{293}$ El artículo 42.1 del Código aduanero de la Unión establece la Imposición de sanciones de la siguiente manera: «1. Cada Estado miembro establecerá sanciones en caso de incumplimiento de la legislación aduanera. Dichas sanciones serán efectivas, proporcionadas y disuasorias. 2. Cuando se impongan sanciones administrativas, estas podrán adoptar, inter alia, una o ambas de las dos formas siguientes: a) una carga pecuniaria impuesta por las autoridades aduaneras, incluido, cuando proceda, un pago suplementario que sustituya a la sanción penal aplicable; b) la revocación, suspensión o modificación de cualquier autorización de la que goce la persona sancionada. 3. Los Estados miembros notificarán a la Comisión, en el plazo de 180 días a partir de la fecha de aplicación del presente artículos e determine con arreglo al artículo 288, apartado 2, las disposiciones nacionales vigentes contempladas en el apartado 1 del presente artículo y comunicarán sin demora cualquier modificación posterior que afecte a dichas disposiciones». Verbigracia Ley Orgánica 6/2011, de 30 de junio, por la que se modifica la Ley Orgánica 12/1995, de 12 de diciembre, de represión del contrabando.
}

${ }^{294}$ En este mismo sentido ver las Conclusiones de la Abogado General del Tribunal de Justicia de la Comunidad Europea, SRA. SHARPSTON, presentadas el 15 de junio de 2006, en el Asunto C-467/04, apartados 141 a 143, diciendo: «141. En virtud de las normas comunitarias aplicables, las autoridades aduaneras están facultadas, dentro de los límites que establece la jurisprudencia del Tribunal de Justicia relativa al principio de proporcionalidad y a la libre circulación de mercancías, (111) para verificar la autenticidad de los documentos que establecen el estatuto de las mercancías y para llevar a cabo inspecciones con vistas a comprobar si se cumplen las normas aduaneras. (112) Para los supuestos de mercancías importadas ilegalmente o de mercancías despachadas ilegalmente a libre práctica, el Código Aduanero y el Reglamento de aplicación prevén que tales mercancías generan una deuda aduanera que deberá satisfacer la persona responsable. (113) 142. De este modo, una vez cumplidos los trámites aduaneros y, en su caso, abonados los derechos debidos, las mercancías importadas de terceros países obtienen el estatuto de mercancías en libre práctica y disfrutan de todos los derechos que correspondan en virtud de las normas comunitarias. Las 
Siendo manifiesto que el elemento objetivo del tributo es la incorporación de la mercancía al circuito económico y no la forma en que ésta se realiza, reforzamos nuestra hipótesis del hecho genérico, pues en todas las consideraciones vertidas por las distintas jurisprudencias citadas en este apartado, sale a resaltar como hecho generador de tributación la posibilidad de incorporación de la mercancía al circuito económico de la comunidad, que como ya hemos dicho reiteradamente se traduce en la factibilidad de comercialización o consumo de la mercancía extracomunitaria en el territorio comunitario.

autoridades nacionales están vinculadas por dichas normas comunitarias. Las autoridades de los demás Estados miembros deben presumir que toda declaración de las autoridades aduaneras nacionales de que las mercancías se encuentran en libre práctica es válida, salvo prueba en contrario. En este último caso, deberá pagarse la deuda aduanera resultante. En este punto finaliza la aplicación del Derecho aduanero comunitario.143. Así pues, las normas comunitarias se limitan a regular los aspectos de Derecho administrativo de la importación ilegal. Tales normas no se proponen armonizar la regulación jurídica de las infracciones aduaneras por los Derechos penales nacionales. Los Estados miembros conservan la competencia de sancionar penalmente las infracciones aduaneras del Código aduanero, (114) con sujeción a los requisitos establecidos por el Tribunal de Justicia, especialmente en cuanto a la proporcionalidad. Por consiguiente, la cuestión de si la importación ilegal produce (además de una deuda aduanera en virtud del Derecho administrativo) una infracción aduanera sujeta a responsabilidad criminal debe determinarse de conformidad con el Derecho penal nacional aplicable».

${ }^{295}$ Reglamento CE- 2454/93. Artículo 866 «Sin perjuicio del cumplimiento de las disposiciones previstas en materia de prohibición o de restricción eventualmente aplicables a la mercancía de que se trate, cuando haya nacido una deuda aduanera de importación, en virtud de lo dispuesto en los artículos 202, 203, 204 o 205 del Código y los derechos de importación hayan sido pagados, la mercancía de que se trata se considerará como mercancía comunitaria sin que sea necesario hacer una declaración de despacho a libre práctica». 
El hecho de que la incorporación se dé ilícitamente, no impide que se cumplan todos los elementos que componen el hecho imponible genérico, es decir la entrada de una mercancía extracomunitaria en el territorio aduanero de la comunidad, con la potencialidad real de ser comercializadas o consumidas en el mismo, lo que equivaldría a su incorporación al circuito económico. Por lo que cumpliéndose los presupuestos previstos en la norma, no existe impedimento alguno para que se devengue el tributo y nazca la deuda aduanera $^{296}$, pues como hemos recalcado a lo largo de este capítulo, la sanción y el tributo son independientes uno del otro, lo cual, acorde a las reiteradas jurisprudencias citadas del TJCE, el principio de neutralidad fiscal se opone directamente a una diferenciación entre las operaciones lícitas y las ilícitas ${ }^{297}$; además de que de no ser así, se violarían los principios de generalidad e igualdad tributaria, al exentar indebidamente y tratar de forma

\footnotetext{
${ }^{296}$ Tratamiento análogo al que da el Artículo 10 de la Lei Geral Tributaria Portuguesa en lo que respecta a la tributación de los rendimientos de los actos ilícitos. "Artigo $10^{\circ}$ Tributação de rendimentos ou actos ilícitos. $O$ carácter ilícito da obtenção de rendimentos ou da aquisição, titularidade ou transmissão dos bens não obsta à sua tributação quando esses actos preencham os pressupostos das normas de incidência aplicáveis».

${ }^{297}$ Ver al respecto las sentencias del TJCE dictadas en los asuntos: C-111/92, C-238/95, C3/97, C-158/98, C-455/98, C-354/03, C-355/03, C-484/03, C-439/04 y C-440/04. Hacen referencia al principio de neutralidad fiscal en la percepción del IVA, en los siguientes términos: "Según se ha recordado en el apartado 14, la jurisprudencia del Tribunal de Justicia tiene declarado que el principio de neutralidad fiscal se opone, en materia de percepción del IVA, a una diferenciación generalizada entre las operaciones lícitas y las operaciones ilícitas. De ello se desprende que la calificación de un comportamiento como digno de represión no da lugar, por sí sola, a una excepción a la tributación en concepto del IVA, sino que una excepción de esta índole sólo opera en situaciones específicas en las que está excluida toda competencia entre un sector económico lícito y otro ilícito debido a las características especiales de determinadas mercancías o de determinadas prestaciones».
} 
desigual dos hechos iguales ${ }^{298}$, que es la incorporación de la mercancía al circuito económico de la comunidad.

\subsubsection{El traslado en circunstancias especiales.}

Como recordaremos el artículo 202. 1 del Código Aduanero Comunitario, contemplaba como introducción irregular cualquier introducción que viole las disposiciones de los artículos 38 al 41 y del segundo guion del artículo 177. El artículo 137 del Código Aduanero de la Unión (Anterior 92 del Código Aduanero Modernizado y 39 del Código Aduanero Comunitario) ${ }^{299}$, que lleva título

298 GALARZA, C. "Tributación y actos ilícitos: ¿existen trabas éticas o morales para la tributación de los actos ilícitos?”. En: Dereito: Revista xuridica da Universidade de Santiago de Compostela. Vol. 15, ํ2, 2006, p. 83-84. "Cuando la comisión de un acto ilícito encuadra en todos sus aspectos en el hecho imponible de un tributo, podría ser factible exigir su tributación sin que ello constituya en un proceder alejado de la ética por parte del Estado, que se encontraría así únicamente cumpliendo con lo preceptuado por la norma del tributo. A nuestro entender, de no exigirse el tributo por tratarse de un acto ilícito aunque encuadre en el hecho imponible, se vulneraria el principio de igualdad puesto que existiría deuda tributaria cuando el acto es lícito, pero no cuando el mismo acto es llevado a cabo en torno a circunstancias ilícitas, resultando entonces éste para su autor mucho más redituable que si realizara uno lícito».

299 "Artículo 137 Traslado en circunstancias especiales 1. Cuando, por caso fortuito o fuerza mayor, no pueda cumplirse la obligación establecida en el artículo 135, apartado 1, la persona vinculada por dicha obligación o toda otra persona que actúe por cuenta de dicha persona informará a las autoridades aduaneras de la situación sin demora. Cuando el caso fortuito o de fuerza mayor no haya ocasionado la pérdida total de las mercancías, se deberá además informar a las autoridades aduaneras del lugar exacto en el que se hallen dichas mercancías.

2. Cuando por caso fortuito o fuerza mayor, los buques o aeronaves contemplados en el artículo 135, apartado 6, se vean obligados a hacer escala o detenerse de forma temporal en el territorio aduanero de la Unión sin poder cumplir la obligación prevista en el artículo 135, apartado 1, la persona que haya introducido el buque o aeronave en el territorio aduanero de la Unión, o cualquier otra persona que actúe por su cuenta, informará sin demora de esta situación a las autoridades aduaneras. 
homónimo al de este apartado, establece una obligación formal de informar a la autoridad aduanera de la entrada de una mercancía al territorio aduanero, cuando por cuestiones de fuerza mayor o caso fortuito, no puedan ser trasladada a los lugares indicados de conformidad al artículo135 del $\mathrm{CAU}^{300}$, convirtiéndose en una excepción únicamente a la obligación formal del traslado, pues en concordancia con lo establecido por el artículo 5, apartado 33 del Código Aduanero de la Unión ${ }^{301}$, el hacer del conocimiento a las autoridades aduaneras de la entrada de la mercancía al territorio comunitario, equivale a la presentación de la mercancía en aduana.

3. Las autoridades aduaneras determinarán las medidas que deban adoptarse para facilitar la vigilancia aduanera de las mercancías contempladas en el apartado 1, así como de los buques o aeronaves y de las mercancías que se hallen en ellos en los supuestos del apartado 2, y garantizar, en su caso, su ulterior presentación en una aduana o en cualquier otro lugar designado o autorizado por dichas autoridades».

${ }^{300}$ CONCLUSIONES DE LA ABOGADO GENERAL SRA. JULIANE KOKOTT presentadas el 30 de septiembre de 2004 (1)Asunto C-195/03 Merabi Papismedov y otros. «46. En el presente caso, tampoco hay indicios de una infracción del artículo 39 del Código aduanero. A diferencia del artículo 38 del Código aduanero, dicha disposición establece una obligación de información a las autoridades aduaneras cuando y en la medida en que no pueda cumplirse con la obligación de transporte antes citada por caso fortuito o por fuerza mayor. Sin embargo, se trata de una excepción mediante la cual se sustituye la obligación de transporte por una obligación de información. Si la mercancía ha sido debidamente transportada con arreglo a lo previsto en el artículo 38, apartado 1, letra a), del Código aduanero, no existirá ya ninguna obligación de declaración en virtud del artículo 39 del Código aduanero».

301 «Artículo 5 Definiciones A los efectos del presente código, se entenderá por: «presentación en aduana»: la notificación a las autoridades aduaneras de la llegada de las mercancías a la aduana, o a cualquier otro lugar designado o autorizado por aquellas, y de su disponibilidad para los controles aduaneros"; 
En esencia, existe identidad de este supuesto con la obligación de traslado a lugar apropiado, pues en ambos casos la finalidad de la obligación consiste en garantizar que se informe a las autoridades aduaneras no sólo de la llegada de las mercancías, sino también de todos los datos pertinentes relativos al tipo de artículo o de producto de que se trate, así como a la cantidad de tales mercancías ${ }^{302}$, por lo que sería ocioso repetir aquí las consideraciones vertidas en el apartado inmediato anterior. Nos centraremos así únicamente en definir los presupuestos bajo los cuales se entenderá que existe un caso de fuerza mayor o un caso fortuito.

Dentro de la legislación comunitaria no existe una definición de los conceptos de fuerza mayor o caso fortuito, y ni en la jurisprudencia existe una definición diferenciada entre ambos, sino que conjugan ambos términos en fuerza mayor sin otorgar un concepto autónomo al "caso fortuito", tal como lo pone de manifiesto la Abogado General Sra. Juliane Kokott en sus Conclusiones presentadas el 18 de julio de 2007, en el Asunto C-314/06, argumentando lo siguiente: «En el Derecho comunitario el Tribunal de Justicia no ha delimitado

302 STJCE de 02 de abril de 2009, asunto 459/07, en el caso: Veli Elshani vs Hauptzollamt Linz. Apartado «22. Del propio texto de los artículos 38 a 41 del Código aduanero se desprende que, para que pueda considerarse que una mercancía ha sido introducida de manera regular en el territorio aduanero de la Comunidad, debe, desde su llegada, ser trasladada a una aduana o a una zona franca y ser presentada en aduana. La finalidad de esta última obligación, que corresponde al responsable de la introducción o al que se hace cargo del transporte, es garantizar que se informe a las autoridades aduaneras no sólo de la llegada de las mercancías, sino también de todos los datos pertinentes relativos al tipo de artículo o de producto de que se trate, así como a la cantidad de tales mercancías. En efecto, esta información permitirá la identificación correcta de aquéllas, con vistas a su clasificación arancelaria y, en su caso, al cálculo de los derechos de importación (sentencia Papismedov y otros, antes citada, apartado 27)». 
hasta ahora estos dos conceptos, (15) sino que a menudo los ha examinado conjuntamente con arreglo a los mismos criterios sin más explicaciones. (16) Sin embargo, en la mayoría de los casos el Tribunal de Justicia ha centrado sus consideraciones en el concepto de fuerza mayor, sin atribuir al concepto de caso fortuito un significado autónomo. (17) Por consiguiente, en el caso de autos, el examen deberá centrarse en la interpretación del concepto de fuerza mayor ${ }^{303}$.

Concepto de fuerza mayor: «En el contexto de la normativa aduanera, el concepto de fuerza mayor debe, en principio, entenderse en el sentido de circunstancias ajenas a quien lo invoca, anormales e imprevisibles, cuyas consecuencias no habrían podido evitarse a pesar de toda la diligencia empleada (sentencia de 8 de julio de 2010, Comisión/Italia, C-334/08, Rec. p. I-6865, apartado 46 y jurisprudencia citada). De ello se deriva que, como ha precisado el Tribunal de Justicia, el concepto de fuerza mayor consta de un elemento objetivo, relativo a las circunstancias anormales y ajenas al operador, y de un elemento subjetivo, relativo a la obligación que incumbe al interesado de tomar precauciones contra las consecuencias del acontecimiento anormal, adoptando medidas adecuadas, sin aceptar sacrificios excesivos (sentencia

\footnotetext{
${ }^{303}$ CONCLUSIONES DE LA ABOGADO GENERAL SRA. JULIANE KOKOTT presentadas el 18 de Julio de $2007^{1}(1)$ Asunto C-314/06 Société Pipeline Méditerranée et Rhône (SPMR) contra Administration des douanes et droits indirects y Direction nationale du renseignement et des enquêtes douanières (DNRED). Apartado 27
} 
Société Pipeline Méditerranée et Rhône, antes citada, apartado 24 y jurisprudencia citada)»304.

Por lo que, en conclusión, no habrá obligación de trasladar las mercancías a los recintos aduaneros o demás lugares designados cuando por cuestiones anormales y ajenas al importador, las mercancías no pueden ser físicamente trasladadas a los lugares indicados.

\subsubsection{La presentación en aduana de las mercancías}

El artículo 139 del CAU (Anterior 95 del COM y 40 del CA) ${ }^{305}$, establece el deber de que una vez ingresada la mercancía a un recinto aduanero o a algún otro tipo de lugar autorizado, deberá presentar la mercancía ante la aduana, obligación que comentábamos en el epígrafe anterior se encuentra definida por el artículo 5, inciso 33, como: «la notificación a las autoridades aduaneras de la llegada de las mercancías a la aduana, o a cualquier otro lugar designado o autorizado por aquellas, y de su disponibilidad para los controles aduaneros».

Como se ha venido repitiendo a lo largo del capítulo, la finalidad de la presentación en aduana «es garantizar que se informe a las autoridades

\footnotetext{
${ }^{304}$ STJCE de 14 de junio de 2012, en el asunto C-533/10, caso Compagnie internationale pour la vente à distance (CIVAD) SA y Receveur des douanes de Roubaix, Directeur régional des douanes et droits indirects de Lille, Administration des douanes. Apartados 27 y 28.

305 «Artículo 139 Presentación de las mercancías en aduana 1. Las mercancías introducidas en el territorio aduanero de la Unión serán presentadas en aduana inmediatamente después de su llegada a cualquier aduana designada o a cualquier lugar designado o aprobado por las autoridades aduaneras o a una zona franca por una de las siguientes personas:...»
} 
aduaneras no sólo de la llegada de las mercancías, sino también de todos los datos pertinentes relativos al tipo de artículo o de producto de que se trate, así como a la cantidad de tales mercancías. En efecto, esta información permitirá la identificación correcta de aquéllas, con vistas a su clasificación arancelaria y, en su caso, al cálculo de los derechos de importación»306.

Por lo que habiendo sido agotada y estudiada la parte esencial de este apartado en los apartados anteriores, resulta innecesario el volveros a reproducir en este apartado. Pues como ya vimos en la multicitada jurisprudencia del Tribunal de Justicia de la Comunidad Europea de 02 de abril de 2009, asunto 459/07, la generalidad de supuestos contenido en los artículos 38 al 41, así como el guion segundo del artículo 177, recaen sobre el mismo supuesto de traslado y presentación en aduana, que ha sido ampliamente estudiado.

\subsubsection{La sustracción a la vigilancia aduanera de una mercancía sujeta a derechos de importación}

El artículo 203.1 del Código aduanero establecía como hecho generador de la deuda aduanera "la sustracción a la vigilancia aduanera de una mercancía sujeta a derechos de importación”, pero al igual que el artículo 202 tras las reformas fue fundido en un solo artículo junto con los supuestos previstos por el artículo 202, 204 y 205; hoy contenidos en el artículo 79, inciso a) del Código Aduanero de la Unión.

\footnotetext{
${ }^{306}$ STJCE de 02 de abril de 2009, asunto 459/07,Ob. Cit. Apartado 22
} 
Múltiples sentencias del Tribunal de Justicia de la Comunidad Europea definen la sustracción a la vigilancia aduanera como: "Cualquier acto u omisión que tenga como resultado impedir a la autoridad aduanera competente, aun cuando sólo sea momentáneamente, acceder a una mercancía bajo vigilancia aduanera y efectuar los controles previstos por la normativa aduanera comunitaria» ${ }^{307}$. Por lo que corresponde analizar los conceptos que integran este supuesto a fin de determinar su naturaleza y alcance, iniciando por los conceptos de "vigilancia aduanera" y "controles aduaneros".

El artículo 5, apartado 27) del Código Aduanero de la Unión, define la vigilancia aduanera como: «las tareas desempeñadas generalmente por las autoridades aduaneras para garantizar el cumplimiento de la legislación aduanera y, en su caso, el de otras disposiciones aplicables a las mercancías sujetas a dichas tareas».

Por control aduanero debemos entender, de acuerdo a lo establecido por capítulo 2 del Anexo General de la Convención de Kyoto, «las medidas aplicadas por la Aduana a fin de asegurar el cumplimiento de la ley aduanera». El glosario de términos aduaneros internacionales de la Organización Mundial del Comercio profundiza más en torno a las medidas a aplicar puntualizando

\footnotetext{
${ }^{307}$ véanse las sentencias de 11 de julio de 2002, Liberexim, C-371/99, Rec. p. I-6227, apartado 55; sentencia de 12 de febrero de 2004, Hamann International, C-337/01, Rec. p. I-0000, apartado 31; sentencia de 29 de abril de 2004, British American Tobacco, C-222/01, Rec. p. I-0000, apartado 47; sentencias de 11 de julio de 2002, Liberexim, C-371/99, Rec. p. I-6227, apartado 55 y jurisprudencia citada; de 29 de abril de 2004, British American Tobacco, C-222/01, Rec. p. I-4683, apartado 47 y jurisprudencia citada, y de 20 de enero de 2005, Honeywell Aerospace, C-300/03, Rec. p. I-689, apartado 19; entre otras.
} 
que éstas estarán generalmente relacionadas con la entrada de las mercancías al territorio aduanero pero, más específicamente, con la localización de las mercancías, la naturaleza de los bienes, los procedimientos aduaneros aplicados a la mercancía (tránsito aduanero, etc.). ${ }^{308}$

Así pues, «con arreglo a reiterada jurisprudencia, la sustracción de una mercancía a la vigilancia aduanera presupone tan sólo la reunión de una serie de requisitos de índole objetiva, como la ausencia física de la mercancía del lugar de depósito autorizado en el momento en que la autoridad aduanera quiera realizar la inspección de la citada mercancía. Por tanto, para que se produzca una sustracción a la vigilancia aduanera basta con que se sustraiga objetivamente la mercancía a los posibles controles, con independencia de que la autoridad competente los practique efectivamente»309

Nos encontramos ante un supuesto de impedimento a la actividad inspectora de la autoridad tributaria que tiene los efectos de falta de presentación de la mercancía y cuyo hecho imponible, al igual que los supuestos estudiados en apartados anteriores, se constriñe a un ingreso irregular de la mercancía al territorio comunitario y su posible incorporación al circuito económico de la

${ }^{308}$ Glossary of international customs terms, World Customs Organization, Ob. Cit. P.7 Voz: Customs Control. «Measures applied by the Customs to ensure compliance with Customs law $\left.{ }^{*}\right)$. Note. The measures may be general, e.g., in relation to all goods entering the Customs territory, or may be specifically related to, e.g.: (a) the location of the goods; (b) the nature of the goods (liable to a high rate of duty, etc.); (c) the Customs procedure applied to the goods (Customs transit, etc.). $\left({ }^{*}\right)$ General Annex, Chapters 2 and 6 of the revised Kyoto Convention. Anexo General Capítulo 2"

${ }^{309}$ Sentencia Del Tribunal De Justicia de 12 de junio de 2014, En el asunto C-75/13, en el caso SEK Zollagentur GmbH y Hauptzollamt Gießen. Apartados. 31 y 32 
Comunidad. En este caso, la incorporación se presume realizada al momento que la mercancía es sustraída de la vigilancia aduanera, y la sustracción tiene por objeto incorporar la mercancía sustraída al circuito de económico de la Comunidad $^{310}$. Por tanto en este supuesto, al igual que en todos los supuestos estudiados de importación irregular, estaremos en presencia de una tasa por utilización de bienes de dominio público, según los razonamientos expuestos en el apartado 3.1.1.2 de este estudio.

310 Ver al respecto la STJCE de 05 de Octubre de 1983, asunto 186 y 187/82 en el caso Esercizio Magazzini Generali y Mellina Agosta. Apartado 14. «It appears from the abovementioned article together with the ninth recital of the preamble to the directive that the reasons for the extinction must be based on the fact that the goods have not been used for the economic purpose which justified the application of import duties. In the case of theft, it may be assumed that the goods pass into the Community commercial circuit. It follows that "loss" of the goods for the purposes of the directive does not embrace the concept of theft, regardless of the circumstances in which it has been committed". 



\subsection{EL NACIMIENTO DE LA DEUDA ADUANERA POR INCUMPLIMIENTO.}

Los artículo 204 y 205 del Código Aduanero Comunitario (hoy contenidos en el artículo 79 del Código Aduanero de la Unión) contemplan dos supuestos a los que nosotros hemos denominado genéricamente como "nacimiento de deuda aduanera por incumplimiento o inobservancia", en tanto en ambos supuestos las mercancías ya habían ingresado de forma regular al territorio aduanero comunitario, generándose la deuda cuando el importador deja de cumplir las obligaciones y los requisitos ligados a los distintos regímenes aduaneros ${ }^{311}$. En ambos artículos se describen formas específicas de dichos incumplimientos, mismas que describiremos en los siguientes párrafos.

\subsubsection{La deuda aduanera por incumplimiento}

El artículo 204.1 del Código Aduanero establecía en su apartado a), que dará nacimiento a la deuda aduanera de importación «el incumplimiento de cualquiera de las obligaciones a que quede sujeta una mercancía sometida a derechos de importación como consecuencia de su estancia en depósito temporal o de la utilización del régimen aduanero en el que se encuentre».

Este texto fue remplazado por el que aparece en el artículo 46.1 apartados b) y c) del Código Aduanero Modernizado, mismo texto que perdura en el actual

\footnotetext{
${ }^{311}$ Ver al respecto el ya citado apartado 27 de la STJCE de fecha 11 de julio de 2013, asunto C-273/12.
} 
artículo 79.1 apartado b) y c), del actual Código Aduanero de la Unión, los cuales prescriben:

«Deuda aduanera nacida por incumplimiento 1. Respecto de las mercancías sujetas a derechos de importación, nacerá una deuda aduanera de importación por incumplimiento de alguna de las siguientes circunstancias:...

b) una de las obligaciones establecidas en la legislación aduanera relativa al destino final de las mercancías dentro del territorio aduanero de la Unión;

c) una condición que regule la inclusión de mercancías no pertenecientes a la Unión en un régimen aduanero o la concesión, en virtud del destino final de las mercancías, de una exención de derechos o de una reducción del tipo de los derechos de importación».

Los regímenes aduaneros corresponden, en esencia, al tratamiento y destino que tienen las mercancías al ingresar al territorio comunitario ${ }^{312}$. El artículo 5, inciso 16) define los regímenes aduaneros como «cualquiera de los regímenes en los que puedan incluirse las mercancías con arreglo al código, a saber: a) despacho a libre práctica; b) regímenes especiales; c) exportación;». Por su parte el glosario de términos aduaneros de la Organización Mundial de Aduanas los conceptúa como el tratamiento aplicado por las aduana a los

\footnotetext{
${ }^{312}$ En apoyo de lo dicho ver el artículo 4 del Código Aduanero Comunitario en su apartado 15, donde se define:[ «destino aduanero de una mercancía»: a) la inclusión de las mercancías en un régimen aduanero]
} 
bienes sujetos de control aduanero ${ }^{313}$. El despacho a libre práctica, como ya se advirtió en el punto 2.2.1 de esta tesis, es el régimen general por el cual ingresan las mercancías, en tanto los regímenes especiales constituyen, como su nombre lo indica, un tratamiento especial a las mercancías que se sujetan a ellos ya sea en forma de una suspensión provisional en la aplicación de los derechos arancelarios o en forma de una reducción en los derechos $\operatorname{arancelarios}^{314}$.

${ }^{313}$ Word Customs Organization. GLOSSARY OF INTERNATIONAL CUSTOMS TERMS. November 2013. P 12.Voz: CUSTOMS PROCEDURE (Régime douanier) «Treatment applied by the Customs to goods which are subject to Customs control. 1. The reference to "goods" includes means of transport. 2. There are various Customs procedures which are dealt with in the Kyoto Convention: clearance for home use, Customs warehousing, inward processing, temporary admission, Customs transit, etc».

${ }^{314}$ ABAJO ANTON, L.M. El despacho aduanero.1ㄹ Ed. Madrid: Fundación Cofemental, 2000. P. 30-31 «Los regímenes aduaneros constituyen unos mecanismos especiales que fueron creados con el objeto de cubrir las situaciones que puedan producirse cuando una mercancía se introduce se introduce en un territorio aduanero sin que entre o salga con carácter definitivo. Su finalidad es favorecer o fomentar determinadas actividades económicas y sus efectos sólo se producen cuando tales mercancías hayan cumplido determinados condiciones, denominadas "económicas", y que son variables según los regímenes en que estén incluidas, mejorando, en este caso, la capacidad competitiva de las empresas frente a los mercados exteriores». BERR, C.J. y TRÉMEAU, H. Le droit douanier Communautaire et national, Ob. Cit. P. 254 - 255 "La notion de «régime douanier économique», de création relativement récente, est l'héritière de la notion de "régime suspensif» traditionnellement utilisée, qui s'était révélée incapable de couvrir toutes les situations liées á des activités économiques et mettant en jeu des techniques dérogatoires aux mécanismes de base du processus normal de d'douanent. (...) le vocable de régimes suspensifs et définis comme des régimes permettant le stockage, la circulation ou la transformation sur le territoire douanier, en suspension des droits, taxes et prohibitions, de marchandises étrangères importées destinées á être réexportées ou versées ultérieurement sur le marché intérieur. A l'Origène cette définition couvrait essentiellement les régimes de l'entrepôt, du transit et de l'admission temporaire. (...) les régimes douaniers économiques pourraient être définis comme des régimes destinés á favoriser la développement de certains activités économiques (exportation, par exemple) et á renforcer la capacité 


\section{Carlos Gerardo Herrera Orozco

La incorporación de las mercancías en alguno de los regímenes económicos, permiten que éstas ingresen al territorio aduanero, al margen del circuito económico, por lo que en tanto se cumpla con las condiciones de operación de los regímenes, no nace la deuda aduanera pues las mercancías no ingresan al circuito económico de la comunidad ${ }^{315}$. Si por el contrario existe una vulneración del régimen, y esta violación tiene consecuencias reales que impidan el correcto funcionamiento del régimen aduanero, nacerá la deuda aduanera $^{316}$, pues dicha vulneración presupondría que la mercancía se ha incorporado al circuito económico de la comunidad y por lo tanto es sujeta de

concurrentielle des entreprises sur les marchés internationaux, par la mise en jeu de mécanismes variables selon l'activité considérée (suspension des droits et taxes, octroi anticipé d'avantages fiscaux ou financiers attachés á l'exportation, etc.9 et dont les effets ne sont acquis définitivement que si la marchandise a satisfait á certaines obligations également variables selon les régimes».

${ }^{315}$ SENTENCIA DEL TRIBUNAL DE JUSTICIA de 6 de septiembre de 2012, en el asunto C-28/11, caso Eurogate Distribution $\mathrm{GmbH}$ y Hauptzollamt Hamburg-Stadt. Apartado 28. «Además, procede señalar que la presencia en el territorio aduanero de la Unión de mercancías no comunitarias entraña el riesgo de que tales mercancías acaben integradas en el circuito económico de los Estados miembros sin ser despachadas de aduana, riesgo que el artículo 204 del Código aduanero contribuye a evitar, tal como señala la Comisión (véase la sentencia de 15 de julio de 2010, DSV Road, C-234/09, Rec. p. I-7333, apartado 31)»

${ }^{316}$ SENTENCIA DEL TRIBUNAL DE JUSTICIA de 6 de septiembre de 2012, en el asunto C-262/10, caso Döhler Neuenkirchen GmbH y Hauptzollamt Oldenburg, 35. Según el artículo 204, apartado 1, letra a), del Código aduanero, dará origen a una deuda aduanera de importación el incumplimiento de cualquiera de las obligaciones a que quede sujeta una mercancía sometida a derechos de importación como consecuencia de la utilización del régimen aduanero en el que se encuentre, salvo que se pruebe que dichas infracciones no han tenido consecuencias reales para el correcto funcionamiento de ese régimen. Es preciso señalar, como indica el Abogado General en el punto 49 de sus conclusiones, que todo supuesto que no esté incluido en esa excepción está comprendido en el ámbito de aplicación del artículo 204 del Código aduanero. 
gravamen, al no darse las condiciones para gozar de los beneficios que otorga el régimen ${ }^{317}$.

Al ser, pues, el elemento objetivo de la tributación la incorporación de la mercancía al circuito económico de la Comunidad, al igual que todos los supuestos estudiados anteriormente resulta innecesario el repetirlo en este epígrafe.

${ }^{317}$ IBIDEM. "Apartado 32 Como el Abogado General señaló en el punto 47 de sus conclusiones, la obligación de pagar los derechos aduaneros en tal caso no constituye una sanción administrativa, fiscal o penal, sino la mera consecuencia de la constatación de que no concurren las condiciones exigidas para la obtención de la ventaja que resulta del régimen de depósito aduanero, lo que hace inaplicable la suspensión y justifica, por consiguiente, la imposición de derechos aduaneros. En efecto, ese régimen implica la concesión de una ventaja condicional que no puede otorgarse si no concurren los requisitos que se exigen». 


\subsubsection{La deuda aduanera por consumo en zona franca}

El artículo 205 del Código aduanero establece:

«1. Dará origen a una deuda aduanera de importación: el consumo o la utilización, en una zona franca o en un depósito franco, en condiciones distintas de las previstas por la normativa vigente, de una mercancía sujeta a derechos de importación».

Este supuesto no es sino una forma de incumplimiento de las obligaciones que se encuentra sujeta una mercancía en un régimen específico como lo es la estancia de una mercancía en depósito aduanero o en la zona franca. La materialización del hecho imponible, es decir la introducción de la mercancía en el circuito económico de la Comunidad, se da con el consumo de la mercancía dentro de estas zonas, pues si bien las mercancías no han salido del recinto hacía otra parte del territorio aduanero, con su consumo se han integrado al circuito económico de la Comunidad, pues recordemos que "la entrada de la mercancía al circuito económico de la Comunidad", equivale a que la mercancía importada pueda ser objeto de comercialización o consumo en el mercado interior europeo, como lo deja ver la sentencia del TJCE de fecha 29 de abril de 2010, caso: C-230/08, en su considerando $63^{318}$, desplazando con ello a mercancías comunitarias.

${ }^{318}$ Ob. Cit. 


\section{CAPÍTULO 4. EL DERECHO ADUANERO}

\section{MEXICANO.}

El derecho aduanero mexicano está sustentado en un régimen federal, no presentando mayores particularidades o diferencias a las de cualquier federación.

Su desarrollo histórico es muy interesante, sobre todo en los últimos 30 años en los que se ha revolucionado por completo, al ser uno de los países con más tratados comerciales internacionales firmados, pues a la fecha «México cuenta con una red de 10 Tratados de Libre Comercio con 45 países (TLC), 30 Acuerdos para la Promoción y Protección Recíproca de las Inversiones (APPRIS) y 9 acuerdos de alcance limitado (Acuerdos de Complementación Económica y Acuerdos de Alcance Parcial) en el marco de la Asociación Latinoamericana de Integración $(A L A D I){ }^{319}{ }^{19}$, destacando en este rubro el Tratado de Libre Comercio de América del Norte y por supuesto el Tratado de Libre Comercio con la Comunidad Europea. Tal proliferación de tratados internacionales ha llevado a que el Derecho aduanero mexicano sea uno de los más armonizados según los estándares de la OMC, sobre todo tras la reforma constitucional y el nuevo estatus de los tratados internacionales en el derecho nacional que veremos en apartados siguientes.

\footnotetext{
${ }^{319}$ Dato obtenido de la página web de la Secretaría de Economía del Gobierno de la Republica, el 14/07/14, en la dirección electrónica: http://www.economia.gob.mx/comunidadnegocios/comercio-exterior/tlc-acuerdos
} 



\subsection{Antecedentes de la tributación aduanera en}

\section{México.}

El proceso histórico de la legislación aduanera en México lo podríamos dividir por épocas: la etapa colonial, la post- independentista, el porfiriato, la postrevolucionaria, y la contemporánea. En cada una de estas etapas se han marcado posiciones muy claras y hasta cierto punto contradictorias del derecho aduanero en México.

En este epígrafe se pretende dar un bosquejo general de la evolución histórica del Derecho Aduanero mexicano, sin pretender en ningún momento hacer un estudio exhaustivo del mismo, pues desbordaría el objeto de esta tesis y nos desviaría del objetivo principal perseguido.

\subsubsection{Etapa Colonial Novo-hispana.}

La etapa colonial Novo-Hispana marca a mi gusto el punto de partida de la regulación global del comercio internacional, pues pudiéramos decir sin duda alguna que la línea alejandrina de 1493, es uno de los primeros instrumentos que regula el comercio internacional, al establecer como requisito erga ommnes la licencia de la monarquía española para establecer comercio con las indias occidentales so pena de excomunión ${ }^{320}$. Prohibición que como es de

\footnotetext{
${ }^{320}$ CARVAJAL CONTRERAS, M. Derecho aduanero. 15 a Ed. México: Porrúa, 2009, p. 57-126. NOTA: gran parte del contenido de éste epígrafe (Del periodo Novo hispano hasta él Revolucionario) se ha tomado como base de referencia al presente autor y a fin de evitar lo reiterativo de las citas omitiremos el estarle citando, salvo en los casos en los que se transcriba literalmente.
} 
imaginarse otorga el monopolio comercial a la Corona Española, convirtiéndose en cierta medida en reguladora del comercio transoceánico pues es quien regulaba la entrada y salida de mercancías de esos territorios, estableciendo tributos, cupos y restricciones arancelarias.

Ello derivó en el establecimiento de la Casa de Contratación de Sevilla como oficina encargada del tráfico comercial de Europa con el Nuevo Mundo y de puertos autorizados para la entrada y salida de las mercancías a esos territorios. Así, se establecieron los puertos de Sevilla y Cádiz como únicos puertos de entrada y salida de Europa ${ }^{321}$, en tanto en la Nueva España se estableció como único puerto de entrada y salida de mercancías a Europa el Puerto de Veracruz, y hacía las Filipinas el puerto de Acapulco.

En el plano tributario se estableció, además de otros tributos ${ }^{322}$, el Derecho de Almojarifazgo que es el antecedente directo de los actuales derechos

\footnotetext{
${ }^{321}$ Posteriormente mediante real orden de 15 de enero de 1529 se amplió el Derecho a otros puertos españoles, sin grandes repercusiones pues a decir de Autores como SILVA HERZOG, J. muchos de los puertos habilitados jamás ejercieron ese derecho, salvo dos casos puntuales de un Barco que Zarpo de Málaga en 1551 y otro más de Galicia en 1573. Ver al respecto: SILVA HERZONG, J. "El Comercio de México durante la época colonial". Memorias del Colegio Nacional. 1956/05. P. 45 [En línea]. [Ref. 05 de Agosto de 2014] Disponible en: http://www.colegionacional.org.mx/SACSCMS/XStatic/colegionacional/template/pdf/1956/05\%2 0 -

\%20Ciencias\%20Economicas\%20y\%20Sociales_\%20El\%20comercio\%20de\%20Mexico\%20du rante\%20la\%20epoca\%20colonial\%20por\%20Jesus\%20Silva\%20Herzog.pdf

${ }^{322}$ Derecho de Avería o Havería, Derecho de Almirantazgo, etc. No hacemos mayor referencia a estos tributos pues son tributos que cobraba la Corona Española y no así los territorios Novo Hispanos. Además de que nos desviaríamos del tema de nuestra investigación.
} 
\begin{tabular}{r|r} 
Carlos Gerardo Herrera Orozco & 217 \\
“El nacimiento de la deuda aduanera en la Unión Europea y México. Estudio & compado"
\end{tabular}

$\operatorname{arancelarios}^{323}$ : por la exportación o importación de mercancías de los territorios europeos, exportación 5\% Ad-Valorem a todas las mercancías a excepción de los Vinos que pagaban un 10\%; en tanto a la importación 10\% productos y $20 \%$ a los Vinos. En lo que corresponde a los territorios Novo hispanos, se estableció un 5\% Ad-Valorem general tanto a la importación como a la exportación.

A lo largo de las reformas fiscales que efectuó la dinastía borbónica entre 1760 y 1808, el panorama cambió: se derribaron las barreras arancelarias entre las posesiones españolas, con lo cual se activó la economía regional y el intercambio económico y, sin saberlo, la monarquía fomentó el contacto ideológico entre las colonias, que ya gestaban sus luchas de independencia. El 12 de octubre de 1778 se expide el Reglamento y Aranceles Reales, que libera el tráfico comercial con las colonias españolas y el comercio entre ellas.

${ }^{323}$ ARREOLA, L. y otros. Enciclopedia Española de Derecho y Administración ó Nuevo teatro Universal de la Legislación de España é Indias. Tomo II. Madrid: Imprenta de los Señores Andrés y Diaz, 1849, P. 347-348. Consultada en: http://books.google.com.mx/books?id=KjGNdLoZA4C\&pg=PA547\&dq=derecho+de+almojarifazgo\&hl=es\&sa=X\&ei=2giaU8zWHI6GyA TXtoHICQ\&ved=0CBoQ6AEwADgK\#v=onepage\& $\mathrm{q}=$ derecho\%20de\%20almojarifazgo\& $\mathrm{f}=$ false el día 31/07/2014. "ALMOJARIFAZGO. Derecho que lo antiguo se cobraba en los puertos por la introducción o exportación (sic) de mercaderías nacionales o extranjeras (sic), destinadas ya al consumo propio, ya al estraño (sic). Se conocían tres clases: Almojarifazgo de Indias, ó derecho que pagaban las mercaderías que se importaban de aquellas posesiones ó se esportaban (sic) con destino á las mismas; Almojarifazgo mayor, ó derecho de importación del extranjero ó esportación (sic) para él, y el Almojarifazgo menor, ó derecho que pagaban los géneros y efectos que iban de un puerto á otro del reino. Estos derechos sufrieron muchas alteraciones, hasta que se refundieron en los aranceles formados en 1783. Antes de esta época se dictaron muchas disposiciones sobre los Almojarifazgos de Sevilla, Cádiz, Granada, Murcia, Cartagena é Indias, sus arrendamientos y derechos de los arrendadores, que se contienen en los títulos 22, 23, 24, 25, 2, lib. 9 de la Nueva Recopilación». 


\subsubsection{Periodo Post Independentista.}

Tras la guerra de independencia, el 15 de diciembre de 1821 se publica por la Soberana Junta Provisional Gubernamental el denominado "Arancel General Interino para el Gobierno de las Aduanas Marítimas en el Comercio Libre del Imperio", una norma de carácter proteccionista sobre las mercancías que México producía o pudiese producir, gozando además de un largo listado de mercancías exentas en su mayoría de interés científico y económico.

Se cobraba bajo el sistema de aforo en el que la propia norma arancelaria fija el valor de la mercancía o, en su defecto, por los empleados de la Aduana, de no venir contemplada la mercancía en la norma, cobrándose un $2 \%$ sobre el valor de la mercancía.

El 20 de mayo de 1824 el Soberano Congreso decretó la prohibición de importación de nuevos artículos como harina, azúcar, arroz, café, frutas verdes, trigo, maíz, centeno, cebada, habas, garbanza, lentejas, jamón, tocino, licores, lino, algodón, lana, ropa hecha, ladrillos y tejas, manufactura de barro, metales, oro y plata labrada, maderas y Zapatos.

El 16 de noviembre de 1827, se publica un nuevo arancel, el cual deja libre de gravamen los animales exóticos vivos y disecados, los carruajes de transportes de nueva invención, las casas de madera, el tefan inglés, mapas geográficos, libros impresos, medallas chicas, prisma de cristal. En contrapartida se aumentan a 54 fracciones los artículos prohibidos, siendo lo más destacable las cuatro importantes innovaciones que introduce para fomentar el comercio 
exterior consistentes, en primer lugar, en permitir que la mitad de los derechos se pagaran a los 90 días y la otra a los 180 posteriores a la importación de la mercancía. En segundo lugar, en materia de gestión del tributo, autorizaba a los Estados para que nombrasen interventores a fin de que vigilaran la aplicación y el cobro de los derechos. En tercer lugar, en lo relativo a la determinación de la base imponible, se establecía el sistema específico, o sea, las mercancías pagarían atendiendo a su número, peso y medida según las cuotas fijadas en una tarifa especial incorporada a la Ley, y ya no pagarían por su valor, conservándose el sistema de aforo para los casos no especificados, debiendo de ser efectuado por el administrador de la aduana, el interventor o interventores del Estado y un perito designado por el interesado. Los derechos consistían en un $40 \%$ del precio así determinado. En cuarto lugar, creó un antecedente de lo que hoy serían las zonas francas, al determinar que las mercancías introducidas por Yucatán, Chiapas y las Californias sólo adeudaran tres quintas partes de las cantidades que el arancel marcaba.

El 11 de marzo de 1837, ya en el periodo de Antonio López de Santa Anna ${ }^{324}$, se expide un nuevo arancel, el cual rebaja en un $10 \%$ los tipos respecto al

\footnotetext{
${ }^{324}$ Antonio López de Santa Anna, es uno de los personajes más polémicos en la historia de México, fue 11 veces presidente de la República entre los años de 1833 a 1855 . Tristemente célebre por que en su periodo se realizó la independencia de Texas, la guerra con Estados Unidos de Norte América con la consiguiente pérdida de la mitad del territorio Mexicano, la venta de la Mesilla mediante el tratado del mismo nombre, amén de sus excentricidades como la imposición de contribuciones de un real por cada puerta y cuatro centavos por cada ventana de las casas, decreta, también, un impuesto de dos pesos mensuales por cada caballo frisón (robusto) y un peso por cada caballo flaco; además, un peso al mes por la posesión de cada perro.
} 
anterior y fija el derecho de tonelaje a razón de 12 reales por tonelada; cinco años después, el 30 de abril de 1842, se modifica el arancel reduciendo el impuesto a un $36 \%$ dividido de la siguiente manera: $25 \%$ por concepto de importación; $1 \%$ adicional; $5 \%$ por consumo en puerto y el 5\% por el consumo en el interior. Meses después se recrudecen las prohibiciones aumentando a 145 los objetos prohibidos. El 4 de octubre de 1845 se establece un nuevo arancel en los mismos términos que el anterior, salvo lo que respecta a las sanciones, instaurando penas de decomiso más una multa de cien a mil pesos o en su defecto pena corporal. El 01 junio de 1853 expide el Arancel General de Aduanas Marítimas y Fronterizas, sin mayor novedad que el anterior salvo la derogación de algunas prohibiciones.

En 1856 bajo la presidencia liberal de Juan Álvarez, el 31 enero se expide el nuevo arancel denominado Ordenanza General de Aduanas Marítimas y Fronterizas de la República. Se caracteriza por ser una norma de mayor apertura, pues libera de todo gravamen los productos que en forma directa beneficiaran la industria, agricultura y los transportes, además de reducir las prohibiciones de importación a tan solo 18 productos, que en ese momento eran parte importante de la producción nacional (azúcar, arroz, café, harina de trigo, manteca, aguardiente de caña, zapatos, libros, rebozos, tabaco labrado y en rama). Se fijan así mismo los derechos ad valorem sobre valor factura o aforo, y de cuota fija, y se retoma el pago diferido de los derechos, los cuales se podían pagar en dos plazos: uno a los 40 días y la otra mitad a los 80 días. Establece además cinco derechos adicionales de la siguiente forma: 
○ Municipal: 1 real por bulto

○ Derecho de mejoras materiales: 1/5 parte del derecho de importación.

○ Derecho de Internación: 1/10 derechos importación

○ Derecho de contrarregistro: 1/5 del total de los derechos de importación

- Derechos de amortización de la Deuda Pública Liquidada y consolidada: 1/4 parte derechos de importación.

La Constitución de 1857 toma los orígenes del pacto Federal, regresando las facultades al Congreso para el establecimiento de aranceles aduaneros ${ }^{325}$, la prohibición de aduanas locales y gravámenes estatales al comercio exterior ${ }^{326}$, así como el control y administración de los almacenes nacionales de depósito $^{327}$, de forma casi idéntica a como lo contempla la vigente Constitución de 1917.

${ }^{325}$ Constitución Política de los Estados Unidos Mexicanos de 12 de enero de 1853. «Artículo 72. El congreso tiene facultad:.. IX. Para expedir aranceles sobre el comercio extranjero, y para impedir, por medio de bases generales, que en el comercio de Estado á Estado, se establezcan restricciones onerosas".

${ }^{326}$ Ibídem. "Artículo 112. Tampoco pueden, sin consentimiento del congreso de la Unión: I. Establecer derechos de tonelaje ni otro alguno de puerto; ni imponer contribuciones ó derechos sobre importaciones ó exportaciones. Artículo 124. Para el día 1o de Junio de 1858 quedarán abolidas las alcabalas y aduanas interiores en toda la República».

${ }^{327}$ Ibídem. "Artículo 125. Estarán bajo la inmediata inspección de los poderes federales los fuertes, cuarteles, almacenes de depósitos y demás edificios necesarios al gobierno de la Unión». 
Desafortunadamente, como menciona CARVAJAL CONTRERAS, los distintos movimientos armados que se suscitaron en el país los años siguientes (Guerra de los tres años, intervención francesa) impidieron se llevaran a cabo. No obstante en 01 de enero de 1872, en pleno gobierno Juarista, el entonces Ministro de Hacienda Matías Romero, dicta un nuevo arancel que pretende:

«l. Refundir en una sola cuota los diversos derechos a la importación.

II. Establecer el derecho de importación por regla general con cuota fija, tomando como base el valor de la factura o aforo

III. Aumentar la tarifa con muchos artículos no considerados en la ordenanza vigente, a fin de evitar las diversas cotizaciones que se hacen en las diferentes aduanas de esos productos. El número de efectos clasificados en la vigente tarifa es de 525 y en el nuevo arancel será de 775.

IV. Abolir las prohibiciones.

V. Ensanchar en todo lo posible la lista de mercancías extranjeras que hayan pagado su derecho de importación.

VI. Abolir las restricciones onerosas para el tránsito en la República de mercancías extranjeras que hayan pagado su derecho de importación.

VII. Establecer derechos uniformes sobre las mercancías extranjeras.

VIII. Conceder a los buques nacionales exención del derecho de faro; y cobrarlo a los extranjeros en los puertos en que exista. 
IX. El derecho del práctico sólo se pagará por quien lo solicite.

X. Conceder las franquicias posibles al comercio extranjero, facilitando la exportación de los productos nacionales y abriendo nuestras costas al comercio de exportación.

XI. Autorizar la exportación de metales preciosos en pasta.

XII. Autorizar el tránsito de mercancía extranjera por territorio nacional.

XIII. Simplificar todas las operaciones aduaneras en provecho del comercio de importación.

XIV. Adoptar el Sistema Métrico Decimal.

$\mathrm{XV}$. Recopilar en un solo cuerpo todas las disposiciones conexas $y$ similares ${ }^{328}$

${ }^{328}$ CARVAJAL CONTRERAS, M. Derecho aduanero. Ob.Cit. p. 71 y 72 


\subsubsection{El Porfiriato}

Durante el Porfiriato (1876 - 1911), el 27 de noviembre de 1880, se refunde en un solo texto todas las disposiciones arancelarias que, a decir de CRUZ BARNEY, pretendía:

«1. Simplificar y aclarar la nomenclatura de la tarifa sin alterar las cuotas de pago sino en los casos de contradicción manifiesta.

2. Unificar los diversos impuestos a las mercancías extranjeras en una sola cuota.

3. Sustituir el derecho sobre aforo o sobre valor factura por cuotas fijas.

4. Ajustar las cuotas a la unidad de peso decimal, en pesos y centavos enteros.

5. Cobrar por peso neto las cuotas que incluyen el de los envases.

6. Simplificar y abreviar el despacho de las mercancías.

7. Simplificar y abreviar los procedimientos administrativos y judiciales a que se refiere el arancel de 1880, evitando que el funcionario interesado en la imposición de la pena pueda fallar sobre los mismos.

8. Modificar la legislación existente sobre el reparto del producto de las penas marcadas en el arancel» 329 .

${ }^{329}$ CRUZ BARNEY, O. El Comercio exterior de México, 1821 -1928. 1르 Ed. México: UNAM Instituto de Investigaciones Jurídicas, 2005, p. 130. 
El 24 enero 1885, se deroga el anterior arancel, se reducen a 21 mercancías las libres de arancel, se abolen los aforos quedando únicamente el específico y se produce un incremento de las cuotas.

La etapa Revolucionaria (1910 a 1917) está marcada por su gran inestabilidad y el caudillismo, por lo que a ciencia cierta no existió régimen aduanero único, pues las aduanas eran controladas por los distintos bandos, imponiendo cada uno sus medidas de acorde sus propios criterios.

\subsubsection{Periodo Post- Revolucionario}

Tras la promulgación de la Constitución de 1917, se vuelve al modelo contemplado en la Constitución de 1857 regresando el control del Comercio Internacional a la Federación, no habiendo cambios reales en la legislación operativa hasta el 1 de enero de 1930 que abroga la Ley anterior.

«Esta normativa intentó modernizar y simplificar los procedimientos para el despacho de mercancías en las aduanas, junto con ella se pretendió la unificación en una sola tarifa de los diferentes impuestos» ${ }^{330}$.

El 19 de agosto de 1935 se expide una nueva Ley Aduanal que contemplaba un régimen para los agentes aduanales y hace la separación entre impuestos y multas.

\footnotetext{
330 Información obtenida de la página de la Dirección General de Aduanas de México [Consultada el 07 de agosto de 2014], en el sitio: http://www.aduanas.gob.mx/aduana_mexico/2008/quienes_somos/138_10019.html
} 
El 18 de marzo de 1952 entra en vigor el Código aduanero, el cual constituye el antecedente inmediato de nuestra actual legislación. Vigente hasta 1982, durante el período de sustitución de importaciones. Señalaba los lugares para realizar la introducción o extracción de mercancías, los casos de excepción para comerciar con los países, los requisitos especiales, las prohibiciones y la documentación para la operación; así como los productos sujetos a contribuciones aduaneras.

La agilización o la posibilidad de la planeación de trámites aduanales dependían del movimiento de las mercancías y sus puntos de entrada o salida. La aduana, desde entonces y como parte de la consolidación del Estado nacional, tuvo un papel relevante para la protección y el fomento de la industria nacional mediante las barreras arancelarias, limitando las importaciones y estimulando con ello la producción interna. Cuando los aranceles no fueron suficientes para contener las importaciones, lo cual sucedió en 1956, se implantó el permiso previo de importación. Después, en 1961, con el objetivo de tener un sistema arancelario más congruente, se adoptó la Nomenclatura Arancelaria de Bruselas. 


\subsection{5. Época contemporánea}

La Ley Aduanera, publicada el 30 de diciembre de 1981, es el comienzo de un nuevo periodo político y económico en México, en el que se abandona el modelo populista y de económica cerrada, que habían estado manejando los gobiernos Post-revolucionarios, para ingresar en un sistema Neoliberal encabezado por el entonces presidente Miguel de la Madrid Hurtado. Comenzó así el proceso armonizador insertando en su texto la terminología utilizada internacionalmente, simplificó la estructura de los recursos administrativos, a los contemplados en el Código Fiscal de la Federación, instaura la autodeterminación del impuesto, recopila las normas de valoración de mercancías, establece los actuales regímenes aduaneros, y se definen los regímenes aduaneros que conocemos actualmente. Durante este periodo se dio auge a la industria maquiladora a través del Programa de Importación Temporal para Producir Artículos de Exportación (PITEX).

México se incorporó en 1986 al Acuerdo General sobre Aranceles Aduaneros y Comercio (GATT), y en mayo de 1988 al Consejo de Cooperación Aduanera (CCA). Los cambios tuvieron la finalidad de que las relaciones comerciales adquirieran un perfil multilateral y se garantizara que las normas del comercio internacional fueran estables y homogéneas en todo el mundo. Al menos ésa era la premisa de la liberalización del comercio; es decir, que con menos obstáculos al tránsito de mercancías, la economía del país tendría mejores perspectivas de crecimiento. 
El 17 de diciembre de 1992 se firma el Tratado de Libre Comercio de América del Norte, entrando en vigor el 1 de enero de 1994 siendo este evento un punto de inflexión en el desarrollo del comercio internacional en México y por ende de su legislación, al ser el precursor de muchos otros tratados que México firmaría con otros países posteriormente (Entre ellos con la Unión Europea) y de importantes reformas en la Ley aduanera.

Una primera medida fue publicar de manera separada las famosas misceláneas fiscales ${ }^{331}$ de las reglas de comercio exterior. En 1995, cuando la crisis motivó un tropiezo en el crecimiento económico del país, la dirección de la economía no estaba en duda y continuaron los cambios para orientarla hacia el exterior. En 1996 se reformó la Ley Aduanera que, más que elaborar las reglas fiscales para lograr eficacia en la recaudación o en algún otro tipo de fallas, se adecuó a lo requerido en el Tratado de Libre Comercio de América del Norte (TLCAN), además de homologar lo relativo a la valoración de la mercancía en aduana con lo establecido por el artículo VII del GATT.

Un cambio notorio, cuya exigencia tenía como objetivo la agilización de las aduanas, fue la introducción del sistema de revisiones aleatorias, pues al aumentar el tránsito del comercio era imposible la revisión física de todo.

${ }^{331}$ Se conoce como Miscelánea fiscal a las resoluciones «dictadas por las autoridades fiscales que establezcan disposiciones de carácter general agrupándolas de manera que faciliten su conocimiento por parte de los contribuyentes; se podrán publicar aisladamente aquellas disposiciones cuyos efectos se limitan a periodos inferiores a un año. Las resoluciones que se emitan conforme a este inciso y que se refieran a sujeto, objeto, base, tasa o tarifa, no generarán obligaciones o cargas adicionales a las establecidas en las propias leyes fiscales", que de conformidad al artículo 33, Fracción I, inciso g), del Código Fiscal de la Federación, las autoridades fiscales tienen obligación de publicar anualmente. 
También se reforzó el control de los agentes y apoderados aduanales. Las reformas posteriores a la Ley Aduanera fueron en el sentido de analizar y fortalecer los mecanismos que permitieran combatir la evasión en el pago de contribuciones, el cumplimiento de las regulaciones y restricciones no arancelarias $y$, en general, el fraude aduanero, que representa una competencia desleal para la industria nacional y el comercio formal, así como daños al erario público.

«En 1998 nuevamente se reformó la Ley Aduanera, en el sentido de revisar y fortalecer los mecanismos de control que permitieran combatir la evasión en el pago de contribuciones, el cumplimiento de las regulaciones y restricciones no arancelarias y en general el fraude aduanero, que representa una competencia desleal para la industria nacional, el comercio formalmente establecido y el erario público» ${ }^{332}$.

El 01 de julio del año 2000, entra en vigor el Tratado de libre Comercio entre la Unión Europea y México. El 31 de diciembre del mismo año se hacen reformas a la Ley Aduanera, relativas a las exenciones y afectación de mercancías. El 01 de enero de 2002 se reforma nuevamente la Ley Aduanera, permitiendo a los particulares a través del otorgamiento de una concesión brindar el servicio de:

332 Página web de la Dirección General de Aduanas. [Visto el 12/08/2014]: http://www.aduanas.gob.mx/aduana_mexico/2008/quienes_somos/138_10017.html 
"manejo, almacenaje y custodia de las mercancías de comercio exterior"333; facultades hasta entonces reservadas al Estado.

El 2 de febrero de 2006 se hace una nueva reforma de la Ley aduanera relativa a los métodos de determinación del valor en aduana y la secuencia de su aplicación, siendo estos más de acorde a lo establecido en el "Acuerdo relativo a la aplicación del artículo VII del Acuerdo General sobre Aranceles Aduaneros y Comercio de 1994" y recomendaciones de la Organización Mundial de Aduanas.

El 27 de enero de 2012, se reforma el artículo 152 de la Ley aduanera relativo a los métodos de identificación de la mercancía. El 9 de diciembre de 2013 se hace la última gran reforma a la Ley Aduanera mexicana, en la que destaca la incorporación de la declaración electrónica y sistematización de los trámites aduaneros, se le quita el monopolio de la tramitología aduanera al Agente de aduana y se hace opcional su contratación, se elimina el segundo reconocimiento, y se habilitan en casos extraordinarios lugares distintos a las aduanas para el despacho de las mercancías. Unas reformas que pretenden en gran medida armonizar la legislación aduanera mexicana, con el contexto internacional.

\footnotetext{
${ }^{333}$ Ley Aduanera "Artículo 14-A. Los particulares que tengan el uso o goce de un inmueble colindante con un recinto fiscal o de un inmueble ubicado dentro o colindante a un recinto portuario, podrán solicitar al Servicio de Administración Tributaria la autorización para prestar los servicios de manejo, almacenaje y custodia de mercancías, en cuyo caso el inmueble donde se presten dichos servicios se denominará recinto fiscalizado».
} 


\subsection{Fuentes y jerarquía de las normas aduaneras en}

\section{México}

El Derecho aduanero, como rama del Derecho que es, tiene las mismas fuentes que otras ramas de Derecho, con las particularidades propias de su naturaleza tributaria, económica y reguladora del comercio internacional.

El Derecho Tributario Aduanero mexicano, responde a dos grandes tipos de fuentes: a) fuentes internas y b) fuentes internacionales.

Como fuentes internas están consideradas:

I. La Constitución Política de los Estados Unidos Mexicanos.

II. Las leyes federales: Ley de Comercio Exterior, Ley Aduanera, Leyes de los impuestos generales de importación y exportación, Código Fiscal de la Federación, Ley de Metrología y Normalización, Ley del Impuesto sobre la Renta, Ley sobre Impuesto al Valor Agregado, Ley sobre Impuestos Especiales, Ley Federal de Derechos.

III. Reglamentos: Reglamento de la Ley de Comercio Exterior, Reglamento de la Ley Aduanera, Reglamento Interior de la Secretaría de Hacienda y Crédito Público, Reglas Generales de la Secretaría de Hacienda y Crédito Público, Manual de Procedimientos de Operación Aduanera, Resoluciones misceláneas de carácter fiscal general.

IV. Jurisprudencia. 
En cuanto a las fuentes internacionales tenemos:

I. Los Tratados Internacionales suscritos por México.

II. las normas emanadas de Organismos internacionales en los que México es miembro.

III. Las jurisprudencias internacionales de carácter vinculante.

A lo largo de este apartado relacionaremos cada una de estas fuentes junto con su jerarquía normativa en el sistema jurídico mexicano. 


\subsubsection{La Constitución. El control difuso de constitucionalidad.}

En un régimen constitucionalista como el mexicano la Constitución es la fuente primaria y máximo ordenamiento jurídico del Estado, y así lo establece la Constitución Política de los Estados Unidos Mexicanos (CPEUM) en su artículo 133, que a la letra dice:

«Esta Constitución, las leyes del Congreso de la Unión que emanen de ella y todos los Tratados que estén de acuerdo con la misma, celebrados y que se celebren por el Presidente de la República, con aprobación del Senado, serán la Ley Suprema de toda la Unión. Los jueces de cada Estado se arreglarán a dicha Constitución, leyes y tratados, a pesar de las disposiciones en contrario que pueda haber en las Constituciones o leyes de los Estados".

Como apuntábamos anteriormente, el sistema federal centralizó las facultades normativas de comercio exterior en los poderes federales, proscribiendo de manera reiterativa toda posibilidad a los Estados de hacerlo, como veremos en párrafos siguientes.

El artículo 25 Constitucional ${ }^{334}$ es a mi gusto uno de los primeros fundamentos del derecho aduanero en México, pues en primer lugar establece la rectoría

\footnotetext{
${ }^{334}$ CPEUM «Artículo 25. Corresponde al Estado la rectoría del desarrollo nacional para garantizar que éste sea integral y sustentable, que fortalezca la Soberanía de la Nación y su régimen democrático y que, mediante la competitividad, el fomento del crecimiento económico y el empleo y una más justa distribución del ingreso y la riqueza, permita el pleno ejercicio de la libertad y la dignidad de los individuos, grupos y clases sociales, cuya seguridad protege esta
} 
económica del Estado; y en segundo término dicta los principios bajo los cuales se debe de regir la economía estatal, lo que impacta directamente en el comercio y en la legislación aduanera mexicana pues, al decir de la Suprema Corte de Justicia de la Nación (SCJN), «El citado precepto establece esencialmente los principios de la rectoría económica del Estado para garantizar el crecimiento económico del país, lo que se logrará mediante acciones estatales que alienten a determinados sectores productivos, concedan subsidios, otorguen facilidades a empresas de nueva creación, concedan estímulos para importación y exportación de productos y materias primas y sienten las bases de la orientación estatal por medio de un plan nacional; (...) ${ }^{335}$, siendo también fundamento obligatorio para toda exención 0 gravamen tributario de carácter parafiscal ${ }^{336}$. Así pues la normativa aduanera

Constitución. La competitividad se entenderá como el conjunto de condiciones necesarias para generar un mayor crecimiento económico, promoviendo la inversión y la generación de empleo.

El Estado planeará, conducirá, coordinará y orientará la actividad económica nacional, y llevará al cabo la regulación y fomento de las actividades que demande el interés general en el marco de libertades que otorga esta Constitución. (...)».

${ }^{335}$ Época: Novena Época. Registro: 167856. Instancia: Segunda Sala. Tipo de Tesis: Jurisprudencia. Fuente: Semanario Judicial de la Federación y su Gaceta Tomo XXIX, Febrero de 2009. Materia(s): Constitucional Tesis: 2a./J. 1/2009 Página: 461. Rubro: RECTORíA ECONÓMICA DEL ESTADO EN EL DESARROLLO NACIONAL. EL ARTÍCULO 25 DE LA CONSTITUCIÓN POLÍTICA DE LOS ESTADOS UNIDOS MEXICANOS, NO OTORGA A LOS GOBERNADOS GARANTÍA INDIVIDUAL ALGUNA PARA EXIGIR, A TRAVÉS DEL JUICIO DE AMPARO, QUE LAS AUTORIDADES ADOPTEN CIERTAS MEDIDAS, A FIN DE CUMPLIR CON LOS PRINCIPIOS RELATIVOS A AQUÉLLA.

${ }^{336}$ Registro No. 173020. Localización: Novena Época Instancia: Primera Sala. Fuente: Semanario Judicial de la Federación y su Gaceta XXV, Marzo de 2007. Página: 79. Tesis: 1a./J. 28/2007 Jurisprudencia. Materia(s): Administrativa. Rubro: FINES EXTRAFISCALES. LAS FACULTADES DEL ESTADO EN MATERIA DE RECTORÍA ECONÓMICA $Y$ 
mexicana tiene como primera obligación el cumplir con los fines y principios de desarrollo, protección y fomento que contempla el artículo 25 Constitucional.

Algunos autores como CARVAJAL CONTRERAS, RHODE PONCE y WHITKER, dejan fuera del marco constitucional aduanero mexicano el artículo 25 y sin embargo incluyen el artículo $29^{337}$, que a mi parecer no tiene relación alguna pues el citado precepto establece facultades extraordinarias al Presidente de la República en un estado de excepción, que por sus propias características no deben de considerarse como una fuente ordinaria de

DESARROLLO NACIONAL CONSTITUYEN UNO DE SUS FUNDAMENTOS. Texto: «(...)En congruencia con lo anterior, al ser los fines extrafiscales, razones que orientan a las leyes tributarias al control, regulación y fomento de ciertas actividades o sectores económicos, matizando sus objetivos con un equilibrio entre la rectoría estatal y las demandas del interés público, se concluye que el indicado artículo 25 constitucional constituye uno de los fundamentos de dichos fines, cuya aplicación debe reflejarse en la ley, sus exposiciones de motivos, o bien, en cualquiera de sus etapas de formación».

${ }^{337}$ CPEUM «Artículo 29. En los casos de invasión, perturbación grave de la paz pública, o de cualquier otro que ponga a la sociedad en grave peligro o conflicto, solamente el Presidente de los Estados Unidos Mexicanos, con la aprobación del Congreso de la Unión o de la Comisión Permanente cuando aquel no estuviere reunido, podrá restringir o suspender en todo el país o en lugar determinado el ejercicio de los derechos y las garantías que fuesen obstáculo para hacer frente, rápida y fácilmente a la situación; pero deberá hacerlo por un tiempo limitado, por medio de prevenciones generales y sin que la restricción o suspensión se contraiga a determinada persona. Si la restricción o suspensión tuviese lugar hallándose el Congreso reunido, éste concederá las autorizaciones que estime necesarias para que el Ejecutivo haga frente a la situación; pero si se verificase en tiempo de receso, se convocará de inmediato al Congreso para que las acuerde». 
derecho, pues la aplicación de dichas facultades obedece a hechos y circunstancias puntuales señaladas en el propio texto del artículo ${ }^{338}$.

${ }^{338}$ Ver en este sentido la Tesis jurisprudencial. Época: Novena Época. Registro: 189109. Instancia: Segunda Sala. Tipo de Tesis: Aislada. Fuente: Semanario Judicial de la Federación y su Gaceta Tomo XIV, Agosto de 2001. Materia(s): Constitucional. Tesis: 2a. CXXIX/2001. Página: 226. Rubro: DIVISIÓN DE PODERES. INTERPRETACIÓN HISTÓRICA, CAUSAL Y TELEOLÓGICA DE LA PROHIBICIÓN CONTENIDA EN EL TEXTO ORIGINAL DEL ARTÍCULO 49 DE LA CONSTITUCIÓN POLÍTICA DE LOS ESTADOS UNIDOS MEXICANOS, RELATIVA A QUE EL PODER LEGISLATIVO NO PUEDE DEPOSITARSE EN UN INDIVIDUO. Texto: «Desde la expedición del Acta Constitutiva de la Federación, de treinta y uno de enero de mil ochocientos veinticuatro, en su artículo 9o. se dispuso que "El Poder Supremo de la Federación se divide, para su ejercicio, en Legislativo, Ejecutivo y Judicial; y jamás podrán reunirse dos o más de éstos en una corporación o persona, ni depositarse el Legislativo en un individuo.", texto que prácticamente fue reproducido en el artículo 50 de la Constitución Política de 1857. Ahora bien, encontrándose vigente este último dispositivo, el presidente de la República, en uso de las facultades extraordinarias conferidas por el Congreso de la Unión, especialmente a fines del siglo XIX e inicios del XX, expidió diversos actos formalmente legislativos, destacando, entre otros, el Código de Comercio de quince de septiembre de mil ochocientos ochenta y nueve, respecto del cual se sustentó su constitucionalidad, por la jurisprudencia de esta Suprema Corte de Justicia de la Nación, en razón de que su expedición no implicaba la reunión de dos poderes en uno, ni que pasaran todas las facultades del Poder Legislativo al Ejecutivo, pues se trataba de un acto de colaboración entre ambos órganos. Posteriormente, en relación con el texto establecido originalmente en la Constitución Política de cinco de febrero de mil novecientos diecisiete, destaca que en la exposición de motivos del proyecto respectivo se reprochó que se hubiera otorgado sin el menor obstáculo al jefe del Poder Ejecutivo, la facultad de legislar sobre toda clase de asuntos, habiéndose reducido la función del Poder Legislativo, a delegar facultades, por lo que en el texto original del artículo 49 de la vigente Norma Fundamental, con el fin de terminar con esa situación, se agregó como única excepción a la prohibición consistente en que el Poder Legislativo no puede depositarse en un solo individuo, el caso en que el Ejecutivo de la Unión actuara en ejercicio de las facultades extraordinarias previstas en el artículo 29 de la Constitución Federal, de donde se advierte que con tal dispositivo se buscó evitar que el presidente de la República fuera facultado por el Congreso de la Unión para emitir actos formalmente legislativos, es decir, de la misma jerarquía de las leyes que corresponde emitir a aquél, mas no que la facultad de emitir disposiciones de observancia general se reservara al mencionado órgano legislativo». 
No es discutible la inclusión de la fracción IV, del artículo 31 de la CPEUM ${ }^{339}$, como parte del marco constitucional aduanero, pues el referido artículo es la base constitucional de la tributación, al establecer la obligación de los ciudadanos a tributar de forma proporcional y equitativa por lo que, dada la naturaleza del Derecho aduanero que en gran medida tiene tintes tributarios, es este artículo fundamento esencial de la normativa aduanera mexicana.

La división de poderes contenida en el artículo 49 Constitucional $^{340}$, tiene como única referencia al derecho aduanero, la facultad extraordinaria otorgada al ejecutivo federal en materia de comercio exterior en el artículo 131 del mismo texto constitucional que estudiaremos en párrafos siguientes.

El artículo 73 Constitucional, está dentro de este marco de Constitucionalidad aduanera al establecer las facultades del Congreso ${ }^{341}$ :

339 CPEUM «Artículo 31. Son obligaciones de los mexicanos: (...) IV. Contribuir para los gastos públicos, así de la Federación, como del Distrito Federal o del Estado y Municipio en que residan, de la manera proporcional y equitativa que dispongan las leyes».

${ }^{340}$ Ibidem. "Artículo 49. El Supremo Poder de la Federación se divide para su ejercicio en Legislativo, Ejecutivo y Judicial. No podrán reunirse dos o más de estos Poderes en una sola persona o corporación, ni depositarse el Legislativo en un individuo, salvo el caso de facultades extraordinarias al Ejecutivo de la Unión, conforme a lo dispuesto en el artículo 29. En ningún otro caso, salvo lo dispuesto en el segundo párrafo del artículo 131, se otorgarán facultades extraordinarias para legislar».

341 Denominación que se le da de forma genérica al poder legislativo de conformidad a lo establecido por el artículo 50 de la CPEUM que a la letra dice: «El poder legislativo de los Estados Unidos Mexicanos se deposita en un Congreso general, que se dividirá en dos Cámaras, una de diputados y otra de senadores». 
«VII. Para imponer las contribuciones necesarias a cubrir el Presupuesto.

XVIII. Para establecer casas de moneda, fijar las condiciones que ésta deba tener, dictar reglas para determinar el valor relativo de la moneda extranjera y adoptar un sistema general de pesas y medidas;

XXIX. Para establecer contribuciones: 10. Sobre el comercio exterior;

XXIX-D. Para expedir leyes sobre planeación nacional del desarrollo económico y social, así como en materia de información estadística y geográfica de interés nacional;

XXIX-E. Para expedir leyes para la programación, promoción, concertación y ejecución de acciones de orden económico, especialmente las referentes al abasto y otras que tengan como fin la producción suficiente y oportuna de bienes y servicios, social $y$ nacionalmente necesarios».

Por su parte el artículo 89, establece las facultades del Presidente de la República que en relación con la materia aduanera destacan las siguientes:

«. Promulgar y ejecutar las leyes que expida el Congreso de la Unión, proveyendo en la esfera administrativa a su exacta observancia.

X. Dirigir la política exterior y celebrar tratados internacionales, así como terminar, denunciar, suspender, modificar, enmendar, retirar reservas y formular declaraciones interpretativas sobre 
los mismos, sometiéndolos a la aprobación del Senado. En la conducción de tal política, el titular del Poder Ejecutivo observará los siguientes principios normativos: la autodeterminación de los pueblos; la no intervención; la solución pacífica de controversias; la proscripción de la amenaza o el uso de la fuerza en las relaciones internacionales; la igualdad jurídica de los Estados; la cooperación internacional para el desarrollo; el respeto, la protección y promoción de los derechos humanos y la lucha por la paz y la seguridad internacionales;

XIII. Habilitar toda clase de puertos, establecer aduanas marítimas y fronterizas, y designar su ubicación.

$\boldsymbol{X X}$. Las demás que le confiere expresamente esta Constitución».

Considero que ambos textos constitucionales no requieren mayor explicación para su valoración como fundamentos del Derecho aduanero.

En lo que respecta a los artículos 117 en sus fracciones I, IV, V, VI, VII ${ }^{342}$ y 118 fracción $1^{343}$ de la CPEUM, opino que no pueden ser considerados como

\footnotetext{
${ }^{342}$ CPEUM Artículo 117. «Los Estados no pueden, en ningún caso: I. Celebrar alianza, tratado o coalición con otro Estado ni con las Potencias extranjeras. IV. Gravar el tránsito de personas o cosas que atraviesen su territorio. V. Prohibir ni gravar directa ni indirectamente la entrada a su territorio, ni la salida de él, a ninguna mercancía nacional o extranjera. VI. Gravar la circulación ni el consumo de efectos nacionales o extranjeros, con impuestos o derechos cuya exención se efectúe por aduanas locales, requiera inspección o registro de bultos o exija documentación que acompañe la mercancía. VII. Expedir ni mantener en vigor leyes o disposiciones fiscales que importen diferencias de impues (sic DOF 05-02-1917) o requisitos
} 
fundamento de derecho para las normas aduaneras pues ambos textos no crean facultades en la materia, por el contrario proscriben la competencia estatal de la legislación del comercio exterior y de las aduanas en particular, proscripción que me parece demasiado reiterativa en el texto constitucional, pues además de los dos referidos artículos el párrafo primero del artículo 131, reitera la prohibición diciendo:

«Es facultad privativa de la Federación gravar las mercancías que se importen o exporten, o que pasen de tránsito por el territorio nacional, así como reglamentar en todo tiempo y aún prohibir, por motivos de seguridad o de policía, la circulación en el interior de la República de toda clase de efectos, cualquiera que sea su procedencia; pero sin que la misma Federación pueda establecer, ni dictar, en el Distrito Federal, los impuestos y leyes que expresan las fracciones VI y VII del artículo 117»

Por su parte el párrafo segundo del artículo en comento, otorga potestades en materia de comercio exterior al Presidente de la República, en los siguientes términos:

por razón de la procedencia de mercancías nacionales o extranjeras, ya sea que esta diferencia se establezca respecto de la producción similar de la localidad, o ya entre producciones semejantes de distinta procedencia».

${ }^{343}$ Ibidem. Artículo 118. «Tampoco pueden, sin consentimiento del Congreso de la Unión: I. Establecer derechos de tonelaje, ni otro alguno de puertos, ni imponer contribuciones o derechos sobre importaciones o exportaciones". 
«El Ejecutivo podrá ser facultado por el Congreso de la Unión para aumentar, disminuir o suprimir las cuotas de las tarifas de exportación e importación, expedidas por el propio Congreso, y para crear otras; así como para restringir y para prohibir las importaciones, las exportaciones y el tránsito de productos, artículos y efectos, cuando lo estime urgente, a fin de regular el comercio exterior, la economía del país, la estabilidad de la producción nacional, o de realizar cualquiera otro propósito, en beneficio del país. El propio Ejecutivo al enviar al Congreso el Presupuesto Fiscal de cada año, someterá a su aprobación el uso que hubiese hecho de la facultad concedida».

Esta concesión de facultades al ejecutivo es comprensible desde la perspectiva práctica pues el Ejecutivo, como responsable de la conducción de la política económica, es necesario que tenga las herramientas para hacer frente a las posibles contingencias sin tener que depender de un prolongado proceso legislativo.

Aun cuando no es un tema propiamente aduanero, es algo que no puedo dejar pasar de largo dada su relevancia y actualidad en el sistema jurídico mexicano. Hasta antes de la reforma Constitucional de julio de 2011, el control de constitucionalidad se centraba exclusivamente en el Poder Judicial de la Federación ${ }^{344}$ por los medios contemplados en la propia Constitución ${ }^{345}$, es

\footnotetext{
${ }^{344}$ Ver al respecto ALDRETE VARGAS, A. El control constitucional en México. Sufragio, Revista especializada en Derecho electoral. Publicación del Tribunal Electoral del Poder Judicial del Estado de Jalisco. 3ª́ Época, Vol. 1, Núm. 1, año 2008. P.133-142. TENA
} 
decir: Juicio de amparo, controversia constitucional, acción de inconstitucionalidad, Juicio para la protección de los derechos político electorales del ciudadano, Juicio de Revisión Constitucional en materia electoral.

La reforma Constitucional de junio de 2011, se deriva de la resolución de la Corte Interamericana de Derechos Humanos de fecha 23 de noviembre de 2009, en el caso RADILLA PACHECO VS. ESTADOS UNIDOS

RAMÍREZ, F. El poder judicial federal, defensor de la constitución. En; Derecho Constitucional Mexicano. 20ª Ed. México: Porrúa, 1984, p. $491-511$.

${ }^{345}$ Época: Novena Época. Registro: 190669. Instancia: Pleno. Tipo de Tesis: Jurisprudencia. Fuente: Semanario Judicial de la Federación y su Gaceta Tomo XII, Diciembre de 2000. Materia(s): Constitucional. Tesis: P./J. 155/2000 . Página: 843. Rubro: CONTROL DE CONSTITUCIONALIDAD POR LA SUPREMA CORTE DE JUSTICIA DE LA NACIÓN. CONFORME AL PRINCIPIO DE SUPREMACÍA CONSTITUCIONAL LOS MEDIOS RELATIVOS DEBEN ESTABLECERSE EN LA PROPIA CONSTITUCIÓN FEDERAL Y NO EN UN ORDENAMIENTO INFERIOR. Texto: «En virtud de que el ejercicio de la competencia de la Suprema Corte de Justicia de la Nación, tratándose de los medios de control de la constitucionalidad, tiene por efecto que ese órgano fije el alcance de las normas supremas, que expresan la soberanía popular, debe considerarse que la jerarquía de las bases contenidas en ese Magno Ordenamiento conlleva el que sólo en ellas, mediante la voluntad soberana manifestada por el Constituyente o por el Poder Revisor de la Constitución, pueda establecerse la existencia de los referidos medios; ello sin menoscabo de que el legislador ordinario desarrolle y pormenorice las reglas que precisen su procedencia, sustanciación y resolución. La anterior conclusión se corrobora por lo dispuesto en los diversos preceptos constitucionales que, en términos de lo previsto en el artículo 94 de la propia Constitución General de la República, determinan las bases que rigen la competencia de la Suprema Corte de Justicia, en los que al precisarse los asuntos de su conocimiento, en ningún momento se delega al legislador ordinario la posibilidad de crear diversos medios de control de la constitucionalidad a cargo de aquélla». 
MEXICANOS ${ }^{346}$. Con esta reforma se crea una verdadera revolución en el sistema jurídico mexicano, pues aun cuando se podía desprender del artículo 133 Constitucional $^{347}$ el control difuso de constitucionalidad, por parte de los jueces estatales, al establecer que: «... Los jueces de cada Estado se arreglarán a dicha Constitución, leyes y tratados, a pesar de las disposiciones en contrario que pueda haber en las Constituciones o leyes de los Estados». No es hasta la reforma y adición al artículo $1^{\circ}$, en la que se modifican el párrafo $1^{\circ}$ y $5^{\circ}$, se incluyen los actuales párrafos $2^{\circ}$ y $3^{\circ 348}$, en que el control de constitucionalidad se puede hacer efectivo por todos los niveles de gobierno del Estado Mexicano, haciendo obligatorio para toda autoridad observar los derechos humanos consagrados en la Constitución, como se puede constatar en el siguiente cuadro comparativo:

\begin{tabular}{|c|c|}
\hline $\begin{array}{l}\text { Texto Artículo } 1^{\circ} \text { Constitucional anterior a } \\
\text { la reforma de } 2011\end{array}$ & $\begin{array}{l}\text { Texto artículo } 1^{\circ} \text { Constitucional posterior a } \\
\text { la reforma. (Vigente) }\end{array}$ \\
\hline $\begin{array}{l}\text { Artículo } 1^{\circ} \text {. En los Estados Unidos Mexicanos } \\
\text { todo individuo gozará de las garantías que } \\
\text { otorga esta Constitución, las cuales no podrán } \\
\text { restringirse ni suspenderse, sino en los casos } \\
\text { y con las condiciones que ella misma }\end{array}$ & $\begin{array}{l}\text { Artículo 10. En los Estados Unidos } \\
\text { Mexicanos todas las personas gozarán de los } \\
\text { derechos humanos reconocidos en esta } \\
\text { Constitución y en los tratados internacionales } \\
\text { de los que el Estado Mexicano sea parte, así }\end{array}$ \\
\hline
\end{tabular}

${ }^{346}$ Ver al respecto la conferencia ofrecida por la Ministra OLGA SÁNCHEZ CORDERO DE GARCÍA VILLEGAS, disponible en la página web: https://www.scjn.gob.mx/conocelacorte/ministra/conferencia20111110.pdf

${ }^{347}$ El artículo 133 no ha tenido modificación desde 18 de enero de 1934. 


\begin{tabular}{|c|c|}
\hline $\begin{array}{l}\text { Queda prohibida toda discriminación motivada } \\
\text { por origen étnico o nacional, el género, la } \\
\text { edad, las discapacidades, la condición social, } \\
\text { las condiciones de salud, la religión, las } \\
\text { opiniones, las preferencias, el estado civil o } \\
\text { cualquier otra que atente contra la dignidad } \\
\text { humana y tenga por objeto anular o } \\
\text { menoscabar los derechos y libertades de las } \\
\text { personas. }\end{array}$ & 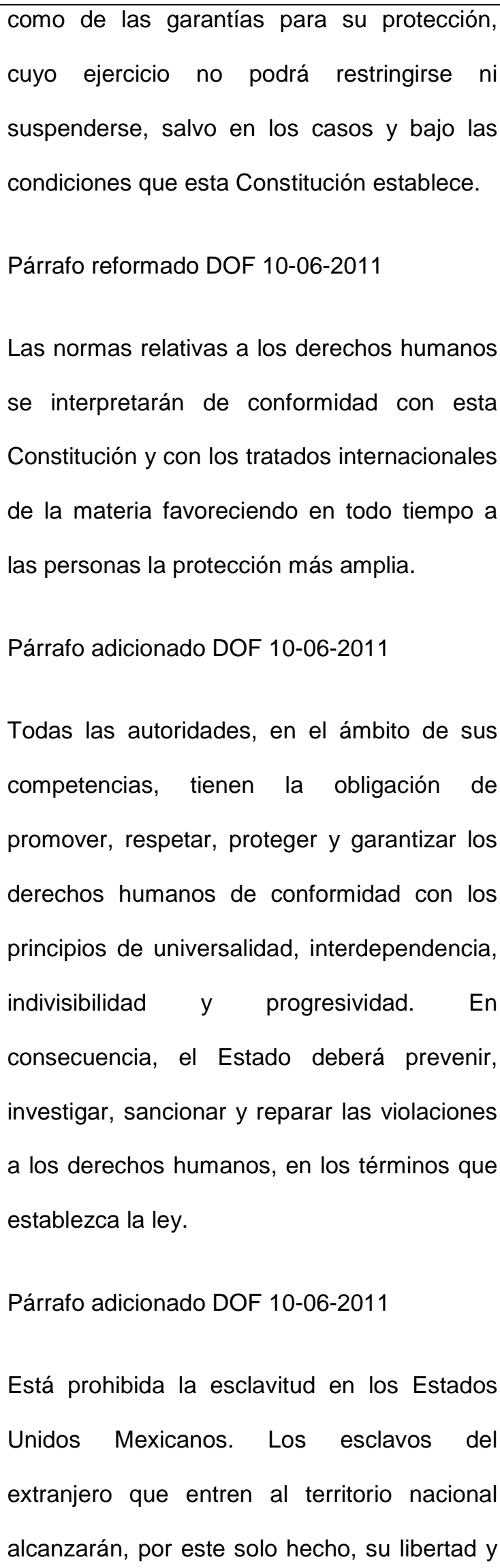 \\
\hline
\end{tabular}




\begin{tabular}{|l|l|}
\hline la protección de las leyes. \\
Queda prohibida toda discriminación motivada \\
por origen étnico o nacional, el género, la \\
edad, las discapacidades, la condición social, \\
las condiciones de salud, la religión, las \\
opiniones, las preferencias sexuales, el estado \\
civil o cualquier otra que atente contra la \\
dignidad humana y tenga por objeto anular o \\
menoscabar los derechos y libertades de las \\
personas. \\
Párrafo reformado DOF 04-12-2006, 10-06- \\
2011 \\
Artículo reformado DOF 14-08-2001
\end{tabular}

Este control difuso de constitucionalidad ha repercutido en todos los ámbitos jurídicos nacionales al hacer oficioso el control de constitucionalidad cuando se advierta que una norma contraviene derechos humanos contenidos en la Constitución, marcando el nuevo paradigma del Derecho mexicano, tal y como lo establece la jurisprudencia bajo el rubro: "CONTROL DE CONSTITUCIONALIDAD Y CONVENCIONALIDAD. CONDICIONES PARA SU EJERCICIO OFICIOSO POR LOS ÓRGANOS JURISDICCIONALES FEDERALES ${ }^{\prime 349}$, cuyo texto señala:

\footnotetext{
${ }^{349}$ Época: Décima Época. Registro: 2006808. Instancia: Segunda Sala Tipo de Tesis: Jurisprudencia. Fuente: Gaceta del Semanario Judicial de la Federación Libro 7, Junio de 2014, Tomo I. Materia(s): Común. Tesis: 2a./J. 69/2014 (10a.) Página: 555.
} 
«El párrafo segundo del artículo 10. de la Constitución Política de los Estados Unidos Mexicanos dispone que las normas relativas a los derechos humanos se interpretarán de conformidad con la propia Constitución y con los tratados internacionales de la materia, favoreciendo en todo tiempo a las personas la protección más amplia, de donde deriva que los tribunales federales, en los asuntos de su competencia, deben realizar el estudio y análisis ex officio sobre la constitucionalidad y convencionalidad de las normas aplicadas en el procedimiento, o en la sentencia o laudo que ponga fin al juicio. Ahora, esta obligación se actualiza únicamente cuando el órgano jurisdiccional advierta que una norma contraviene derechos humanos contenidos en la Constitución Federal o en los tratados internacionales de los que el Estado Mexicano sea parte, aun cuando no haya sido impugnada, porque con su ejercicio oficioso se garantiza la prevalencia de los derechos humanos frente a las normas ordinarias que los contravengan. De otra manera, el ejercicio de constitucionalidad y convencionalidad de normas generales no tendría sentido ni beneficio para el quejoso, y sólo propiciaría una carga, en algunas ocasiones desmedida, en la labor jurisdiccional de los Jueces de Distrito y Magistrados de Circuito». 


\subsubsection{Los Tratados internacionales}

Como apuntábamos al principio del capítulo, México es uno de los países del orbe que más Tratados comerciales internacionales tiene firmados, sin embargo resulta interesante ver cómo ha sido la transición del sistema jurídico mexicano y su relación con el derecho interno.

Recordemos que las relaciones entre el Derecho internacional y el Derecho interno fueron objeto de múltiples debates entre los estudiosos del Derecho, dando origen a múltiples teorías, siendo las dos más destacables el dualismo y el monismo.

El dualismo ${ }^{350}$ o pluralismo, hace una separación absoluta entre el Derecho internacional y el Derecho nacional; por lo que «las normas internacionales son irrelevantes en los ordenamientos internos, necesitando para su aplicación en ellos de un acto especial de recepción ${ }^{351}$.

${ }^{350}$ KELSEN, H. Teoría Pura del Derecho. Vernengo, R.J. (traductor).7ª Ed. México: Porrúa, 1993, P.330. Define al dualismo como «... la tesis tradicional que quisiera ver en el derecho internacional $y$ en los derechos estatales particulares dos sistemas normativos distintos, entre sí independientes, aislados recíprocamente en tanto se funden en dos normas básicas diferentes». RODRÍGUEZ ZAPATA, J. Constitución, Tratados Internacionales y Sistema de Fuentes del Derecho. 1a Ed. Bolonia: Real Colegio de España, 1976, p.24, "son Ilamados dualistas aquellos autores que afirman una separación conceptual entre los ordenamientos estatales y el internacional, considerando que tienen fuentes, sujetos y destinatarios diferentes».

351 Pastor Ridruejo, J. A., Curso de Derecho Internacional Público y Organizaciones Internacionales, Madrid, Tecnos, 9를. Ed., 2003. P.168 
En tanto el monismo concibe «al derecho internacional, junto con los órdenes jurídicos particulares de cada Estado, como un sistema unitario de normas, de igual modo que se acostumbra ver en los órdenes jurídicos estatales particulares una unidad ${ }^{352}$.

El artículo 133 de la CPEUM desde su texto de origen en $1917^{353}$, ubica al sistema jurídico mexicano dentro del sistema monista ${ }^{354}$, pues identifica la unidad de los ordenamientos jurídicos nacionales e internacionales, al establecer: «Esta Constitución, las leyes del Congreso de la Unión que emanen de ella y todos los Tratados que estén de acuerdo con la misma, celebrados y que se celebren por el Presidente de la República, con aprobación del Senado, serán la Ley Suprema de toda la Unión».

Las corrientes antagónicas que se suscitaron dentro de los seguidores de la teoría monista en torno a la supremacía del Derecho nacional, la supremacía del Derecho internacional o los llamados monistas moderados, no fueron ajenas al derecho mexicano que se vio inmerso en muchas de ellas, y

$\overline{352}$ KELSEN, H. Teoría pura del . . Ob. Cit. P. 330

${ }^{353}$ Este artículo solo ha tenido una reforma en 1934, la cual no afectó en forma alguna el espíritu de la norma.

${ }^{354}$ TREJO GARCÍA, E.C. Sistema de Recepción de los Tratados Internacionales en el Derecho Mexicano. México: Centro de Documentación, Información y Análisis, Dirección de Servicios de Investigación y Análisis, Subdirección de Política Exterior, 2006, P.18 «Se concluye que en nuestro país, las relaciones entre el Derecho Internacional y el Derecho Interno obedecen a la tesis monista nacionalista, pues se trata de un solo orden jurídico, en el que prevalece el Derecho Interno, ya que la validez del Derecho Internacional dentro de nuestro Derecho siempre estará definida por la Constitución». 
podemos localizarlas en las jurisprudencias de distintas épocas jurisprudenciales ${ }^{355}$, como veremos más adelante.

La 8 é época jurisprudencial es afín con los postulados de la supremacía del Derecho nacional, donde se considera al Derecho internacional como: «el conjunto de normas que el Estado emplea para conducir sus relaciones con los demás pueblos, y para diferenciarlo podría ser llamado "Derecho Estatal Externo"» ${ }^{356}$; por lo que en caso de conflicto entre ambos sistemas jurídicos, es el derecho internacional el que se debe de subordinar al Derecho interno. Posición que considero análoga a la de los denominados monistas moderados o modernos que adoptan una actitud conciliadora entre el monismo y el dualismo, para quienes «una norma interna contraria al Derecho internacional es válida y obligatoria en el plano interno, aunque haga incurrir en responsabilidad internacional al Estado en cuestión por incumplimiento de una norma internacional que le vincule y le obligue ${ }^{357}$. Pues en ambos casos se habla de una primacía del derecho nacional frente al internacional y México

\footnotetext{
${ }^{355}$ Las Épocas son las etapas cronológicas en los que la SCJN agrupa los criterios publicados en el Semanario Judicial de la Federación, periodos para los cuales no existe un lapso definido, sino que corresponden a reformas constitucionales que pueden modificar los criterios de interpretación de la Corte y de los Tribunales Colegiados de Circuito, ejemplo de ello es la multicomentada reforma constitucional de 2011, que dio inicio a la décima época jurisprudencial. Ver más al respecto el acuerdo general de la Suprema Corte de Justicia de la Nación, mediante el cual se da inicio a la décima época. Disponible en la página web: https://www.scjn.gob.mx/libreria/Documents/AcuerGralesJurisdicPermVig/Anexo-AGP_9_11.pdf ${ }^{356}$ SEPULVEDA, C. Curso de Derecho Internacional Público. 3ª Ed. México: Porrua,1968, P. 67

${ }^{357}$ CARRILLO SALCEDO, J.A. Curso de Derecho Internacional Público. 1aㅡ Ed. Madrid: Tecnos, 1999, P. 149
} 
durante mucho tiempo siguió esta postura que pone de manifiesto la jurisprudencia del Pleno de la Suprema Corte de Justicia de la Nación, Tesis: "LEYES FEDERALES Y TRATADOS INTERNACIONALES. TIENEN LA MISMA JERARQUIA NORMATIVA"358, al exponer la validez de una norma nacional en clara contravención de un tratado internacional, al considerar la ley y los tratados en el mismo nivel jerárquico:

«De conformidad con el artículo 133 de la Constitución, tanto las leyes que emanen de ella, como los tratados internacionales, celebrados por el ejecutivo Federal, aprobados por el Senado de la República y que estén de acuerdo con la misma, ocupan, ambos, el rango inmediatamente inferior a la Constitución en la jerarquía de las normas en el orden jurídico mexicano. Ahora bien, teniendo la misma jerarquía, el tratado internacional no puede ser criterio para determinar la constitucionalidad de una ley ni viceversa. Por ello, la Ley de las Cámaras de Comercio y de las de Industria no puede ser considerada inconstitucional por contrariar lo dispuesto en un tratado internacional».

En la 9á Época jurisprudencial, existe una ligera transición de esa postura y pone a los tratados internacionales en segundo término después de la

\footnotetext{
358 Época: Octava Época. Registro: 205596. Instancia: Pleno. Tipo de Tesis: Aislada. Fuente: Gaceta del Semanario Judicial de la Federación, Núm. 60, Diciembre de 1992. Materia(s): Constitucional. Tesis: P. C/92. Página: 27. RUBRO: LEYES FEDERALES Y TRATADOS INTERNACIONALES. TIENEN LA MISMA JERARQUIA NORMATIVA.
} 
Constitución pero encima de las leyes federales ${ }^{359}$, según lo establecido por la tesis: "TRATADOS INTERNACIONALES. SE UBICAN JERÁRQUICAMENTE POR ENCIMA DE LAS LEYES FEDERALES Y EN UN SEGUNDO PLANO RESPECTO DE LA CONSTITUCIÓN FEDERAL" que a la letra dice:

«Persistentemente en la doctrina se ha formulado la interrogante respecto a la jerarquía de normas en nuestro derecho. Existe unanimidad respecto de que la Constitución Federal es la norma fundamental y que aunque en principio la expresión "... serán la Ley Suprema de toda la Unión ..." parece indicar que no sólo la Carta Magna es la suprema, la objeción es superada por el hecho de que las leyes deben emanar de la Constitución y ser aprobadas por un órgano constituido, como lo es el Congreso de la Unión y de que los tratados deben estar de acuerdo con la Ley Fundamental, lo que claramente indica que sólo la Constitución es la Ley Suprema. El problema respecto a la jerarquía de las demás normas del sistema, ha encontrado en la jurisprudencia y en la doctrina distintas soluciones, entre las que destacan: supremacía del derecho federal frente al local y misma jerarquía de los dos, en sus variantes lisa y Ilana, y con la existencia de "leyes constitucionales", y la de que será ley suprema la que sea calificada de constitucional. No obstante, esta Suprema Corte de Justicia considera que los tratados

\footnotetext{
${ }^{359}$ Registro No. 192867 Localización: Novena Época. Instancia: Pleno Fuente: Semanario Judicial de la Federación y su Gaceta X, Noviembre de 1999 Página: 46 Tesis: P. LXXVII/99. Tesis Aislada Materia(s): Constitucional.
} 
internacionales se encuentran en un segundo plano inmediatamente debajo de la Ley Fundamental y por encima del derecho federal y el local. Esta interpretación del artículo 133 constitucional, deriva de que estos compromisos internacionales son asumidos por el Estado mexicano en su conjunto y comprometen a todas sus autoridades frente a la comunidad internacional; por ello se explica que el Constituyente haya facultado al presidente de la República a suscribir los tratados internacionales en su calidad de jefe de Estado $y$, de la misma manera, el Senado interviene como representante de la voluntad de las entidades federativas $y$, por medio de su ratificación, obliga a sus autoridades».

La anterior tesis se acerca más a la postura de primacía del Derecho internacional sobre el nacional, lo que impactó favorablemente al comercio internacional en México, al tenerse que priorizar lo previsto en los Tratados frente a las normas nacionales.

Al final de la $9^{\mathrm{a}}$ época, y como parte de transición a la $10^{\mathrm{a}}$ época, se crea una nueva jurisprudencia respecto a la jerarquía de los Tratados internacionales bajo el rubro "TRATADOS INTERNACIONALES. CUANDO LOS CONFLICTOS SE SUSCITEN EN RELACIÓN CON DERECHOS HUMANOS, DEBEN UBICARSE A NIVEL DE LA CONSTITUCIÓN." ${ }^{360}$; si bien es cierto se hace la acotación de Tratados Internacionales referentes a Derechos Humanos ello

\footnotetext{
360 Época: Novena Época. Registro: 164509. Instancia: Tribunales Colegiados de Circuito. Tipo de Tesis: Aislada. Fuente: Semanario Judicial de la Federación y su Gaceta. Tomo XXXI, mayo de 2010. Materia(s): Común. Tesis: XI.10.A.T.45 K. Página: 2079.
} 
impacta en la forma de incorporación de los Tratados al Derecho nacional, en esta nueva jurisprudencia se elevan a rango constitucional los Tratados internacionales en materia de Derechos Humanos dejándolos jerárquicamente en igualdad con la Constitución y por ende por encima de las leyes federales. Lo anterior se observa del texto de la jurisprudencia:

«Los tratados o convenciones suscritos por el Estado mexicano relativos a derechos humanos, deben ubicarse a nivel de la Constitución Política de los Estados Unidos Mexicanos, porque dichos instrumentos internacionales se conciben como una extensión de lo previsto en esa Ley Fundamental respecto a los derechos humanos, en tanto que constituyen la razón y el objeto de las instituciones. Por lo que los principios que conforman el derecho subjetivo público, deben adecuarse a las diversas finalidades de los medios de defensa que prevé la propia Constitución y de acuerdo con su artículo 133 las autoridades mexicanas deben respetarlos, por lo que bajo ninguna circunstancia pueden ser ignorados por ellos al actuar de acuerdo a su ámbito competencial».

Esto situaba a México en el extremo de la primacía del Derecho internacional frente al nacional, criterio que no duró mucho pues existió contradicción de tesis y pocos meses después, ya iniciada la $10^{\text {a }}$ época, surge una nueva jurisprudencia enmendando la nota y estableciendo que, si bien los Tratados internacionales tendrán rango de constitucionalidad en caso de conflicto entre estos y la Constitución, se estará a lo establecido en la Constitución, según se 
señala en el rubro: "DERECHOS HUMANOS CONTENIDOS EN LA CONSTITUCIÓN Y EN LOS TRATADOS INTERNACIONALES. CONSTITUYEN EL PARÁMETRO DE CONTROL DE REGULARIDAD CONSTITUCIONAL, PERO CUANDO EN LA CONSTITUCIÓN HAYA UNA RESTRICCIÓN EXPRESA AL EJERCICIO DE AQUÉLLOS, SE DEBE ESTAR A LO QUE ESTABLECE EL TEXTO CONSTITUCIONAL."

Interpretación que se ajusta en cierto grado a lo previsto por la Convención de Viena Sobre el Derecho de los Tratados de 1969 (CVSDT), pues si bien los tratados internacionales son consensuales y prima sobre ellos la no

${ }^{361}$ Época: Décima Época. Registro: 2006224. Instancia: Pleno. Tipo de Tesis: Jurisprudencia. Fuente: Gaceta del Semanario Judicial de la Federación, Libro 5, abril de 2014, Tomo I. Materia(s): Constitucional. Tesis: P./J. 20/2014 (10a.) Página: 202.. Texto: «El primer párrafo del artículo 10. constitucional reconoce un conjunto de derechos humanos cuyas fuentes son la Constitución y los tratados internacionales de los cuales el Estado Mexicano sea parte. De la interpretación literal, sistemática y originalista del contenido de las reformas constitucionales de seis y diez de junio de dos mil once, se desprende que las normas de derechos humanos, independientemente de su fuente, no se relacionan en términos jerárquicos, entendiendo que, derivado de la parte final del primer párrafo del citado artículo 10., cuando en la Constitución haya una restricción expresa al ejercicio de los derechos humanos, se deberá estar a lo que indica la norma constitucional, ya que el principio que le brinda supremacía comporta el encumbramiento de la Constitución como norma fundamental del orden jurídico mexicano, lo que a su vez implica que el resto de las normas jurídicas deben ser acordes con la misma, tanto en un sentido formal como material, circunstancia que no ha cambiado; lo que sí ha evolucionado a raíz de las reformas constitucionales en comento es la configuración del conjunto de normas jurídicas respecto de las cuales puede predicarse dicha supremacía en el orden jurídico mexicano. Esta transformación se explica por la ampliación del catálogo de derechos humanos previsto dentro de la Constitución Política de los Estados Unidos Mexicanos, el cual evidentemente puede calificarse como parte del conjunto normativo que goza de esta supremacía constitucional. En este sentido, los derechos humanos, en su conjunto, constituyen el parámetro de control de regularidad constitucional, conforme al cual debe analizarse la validez de las normas y actos que forman parte del orden jurídico mexicano». 
contravención de una norma imperativa del Derecho internacional general ${ }^{362}$ que garantiza el respeto absoluto de los Derechos Humanos, así como los principios del libre consentimiento, buena fe y la norma pacta sunt servanda ${ }^{363}$, únicamente serán obligatorios y jerárquicamente superiores a las normas internas, en el tiempo, materia y forma que se establezca para tal efecto en el propio tratado, sin que se pueda «invocar las disposiciones de su derecho interno como justificación del incumplimiento de un tratado» ${ }^{364}$. Lo cual será así salvo que la violación al Derecho interno afecte a una norma de importancia fundamental ${ }^{365}$ como sería la Constitución, pues se estaría en el supuesto de nulidad del tratado y la no obligación al cumplimiento expreso.

\footnotetext{
${ }^{362}$ Convención de Viene sobre el Derecho de los Tratados de 1969 (CVSDT) en su artículo 53 establece que: «Es nulo todo tratado que, en el momento de su celebración, este en oposición con una norma imperativa de derecho internacional general. Para los efectos de la presente Convención, una norma imperativa de derecho internacional general es una norma aceptada y reconocida por la comunidad internacional de Estados en su conjunto como norma que no admite acuerdo en contrario y que sólo puede ser modificada por una norma ulterior de derecho internacional general que tenga el mismo carácter».
}

${ }^{363}$ CVSDT. Art. 26 «"Pacta Sunt Servanda". Todo tratado en vigor obliga a las partes y debe de ser cumplido de buena fe»

${ }^{364}$ CVSDT. Art. 27

${ }^{365}$ CVSDT. Art.46 "Disposiciones de derecho interno concernientes a la competencia para celebrar tratados. 1. El hecho de que el consentimiento de un Estado en obligarse por un tratado haya sido manifiesto en violación de una disposición de su derecho interno concerniente a la competencia para celebrar tratados no podrá ser alegado por dicho Estado como vicio de su consentimiento, a menos que esa violación sea manifiesta y afecte a una norma de importancia fundamental de su derecho interno. 2. Una violación es manifiesta si resulta objetivamente evidente para cualquier Estado que proceda en la materia conforme a la práctica usual y de buena fe». 
Por tanto, gran parte de esa jerarquía será otorgada por los textos Constitucionales, que limitarán las obligaciones y materias que podrán ser sujetas de convenio o sesión por medio de tratados internacionales, así como las materias que quedan excluidas de los mismos.

Lo que no deja de ser paradójico pues la multicitada enmienda constitucional deriva de la ya citada sentencia de la Corte Interamericana de Derechos Humanos en el caso Rosendo Radilla Pacheco vs Los Estados Unidos Mexicanos. Por lo que a pesar de lo dictado en la jurisprudencia antes citada, en caso de oposición de la Constitución y los Tratados Internacionales en materia de Derechos humanos, se tendría el antecedente del caso Rosendo Radilla Pacheco, pudiéndose repetir la historia y la necesidad de enmendar la Constitución para ajustarse a lo pactado, pues aun cuando sea norma fundamental, la interpretación contemporánea del derecho siempre será prohomine.

En definitiva, de facto, en nuestro sistema jurídico la jerarquía normativa de los Tratados internacionales quedaría de la siguiente manera:

Constitución y Tratados Internacionales en materia de Derechos Humanos como norma suprema, en segundo término los Tratados internacionales en otras materias y en tercer término las leyes federales. 


\subsubsection{Las Leyes Federales}

Como ya se mencionó en el apartado referente a la Constitución Política de los Estados Unidos Mexicanos, la materia de comercio exterior en general y la aduanera en particular, es exclusiva de la federación, por lo que son los poderes federales los que legislan, reglamentan, gestionan, recaudan, administran y juzgan todo lo relativo a estas materias, excluyendo expresamente a los Estados.

En México no existe una codificación de la normativa aduanera, sino que ésta se encuentra dispersa en varias normas entre las que destacan:

- Ley Aduanera,

- Ley de los Impuestos Generales de Importación y de Exportación,

- Ley de Comercio Exterior

Con independencia de que más adelante veamos detenidamente las normas antes descritas cuando estudiemos el tributo aduanero en México, considero pertinente hacer un breve bosquejo de cada una de ellas.

La Ley aduanera actual se publica en el Diario Oficial de la Federación el 15 de diciembre de 1995, entrando en vigor el 01 de enero de 1996. Es la norma sustantiva de la materia como lo deja en claro en su Artículo $1^{0}$ al establecer el marco normativo de las aduanas en México: «Esta Ley, las de los Impuestos Generales de Importación y Exportación y las demás leyes y ordenamientos aplicables, regulan la entrada al territorio nacional y la salida del mismo de mercancías y de los medios en que se transportan o conducen, el despacho 
aduanero y los hechos o actos que deriven de éste o de dicha entrada o salida de mercancías». El 30 de diciembre de 1996 se adiciona este párrafo instituyendo la supletoriedad del Código Fiscal de la Federación a lo dispuesto en la Ley aduanera.

La vigente Ley de Impuestos Generales a la Importación y Exportación nace en el 22 de febrero de 2007, tras la abrogación dos días antes de la Ley del mismo nombre. Consta de dos únicos artículos de naturaleza netamente cuantitativa, pues en el primero de ellos contiene la tarifa de aplicación de los impuestos de importación y exportación, en tanto en el segundo contiene las reglas complementarías de aplicación. La configuración de la tarifa es de acorde al sistema armonizado de codificación de mercancías del que México es parte desde 1991, no obstante de haberlo adoptado desde 1988.

La Ley de Comercio Exterior se expide el 27 de Julio de 1993, en sustitución de la abrogada Ley Reglamentaria del Artículo 131 de la Constitución Política de los Estados Unidos Mexicanos en Materia de Comercio Exterior, que en su artículo $1^{\circ}$ establecía claramente que el objeto de la norma era regular las facultades concedidas en materia de comercio exterior al Ejecutivo Federal en el párrafo $2^{\circ}$ del artículo 131 de la CPEUM, consistentes en:

«I.- Aumentar, disminuir o suprimir las cuotas arancelarias de las tarifas de exportación e importación y para crear otras. No podrán establecerse cuotas diferentes a las generales establecidas, salvo cuando existan compromisos internacionales que así lo justifiquen. 
II.- Establecer medidas de regulación o restricciones a la exportación o importación de mercancías consistentes en:

a.- Requisito de permiso previo para exportar o importar mercancías de manera temporal o definitiva, inclusive a las zonas libres del país.

b.- Cupos máximos de mercancías de exportación o de importación en razón de los excedentes de producción, de los requerimientos del mercado o de los acuerdos y convenios internacionales.

c.- Cuotas compensatorias, provisionales y definitivas, a la importación de mercancías en condiciones de prácticas desleales de comercio internacional, las que serán aplicables independientemente del arancel que corresponda a la mercancía de que se trate.

d.- Prohibición de importación o exportación de mercancías.

III.- Restricción de la circulación o el tránsito por el territorio nacional de las mercancías procedentes del y destinadas al extranjero, por razones de seguridad nacional, de salud pública, de sanidad fitopecuaria o conservación o aprovechamiento de especies» ${ }^{366}$.

La Ley de Comercio Exterior de 1993 va más allá de la regulación de estas facultades y legisla sobre cuestiones sustanciales de la tributación aduanera como es el origen de la mercancía, los aranceles y medidas de regulación y ${ }^{366}$ Artículo $1^{\circ}$ de la Ley Reglamentaria del Artículo 131 de la Constitución Política de los Estados Unidos Mexicanos en Materia de Comercio Exterior. 
restricción arancelarias del comercio exterior, las medidas de regulación y restricción no arancelarias, los cupos arancelarios, el dumping, los permisos previos, las salvaguardias, las cuotas compensatorias, etc.

\subsubsection{Los Decretos Ley}

El decreto ley es una figura atípica en el sistema jurídico mexicano, que aun cuando no exista referencia expresa de ella en ninguna legislación o jurisprudencia de la Suprema Corte de Justicia de la Nación, tiene especial trascendencia en el ámbito del comercio internacional, en virtud de la atribución expresa conferida por el artículo 131 Constitucional al Ejecutivo para realizar actos formalmente legislativos en materia de comercio exterior, en los términos vistos en el apartado anterior.

La jurisprudencia de la SCJN ve en la Ley de Comercio Exterior, el texto jurídico a través del cual se realiza la delegación de potestades tributarias en comercio exterior a favor del Presidente de la República ${ }^{367}$. Estas facultades

\footnotetext{
367Época: Novena Época. Registro: 171828. Instancia: Segunda Sala. Tipo de Tesis: Jurisprudencia. Fuente: Semanario Judicial de la Federación y su Gaceta Tomo XXVI, Agosto de 2007. Materia(s): Constitucional, Administrativa. Tesis: 2a./J. 121/2007. Página: 415. RUBRO: COMERCIO EXTERIOR. LA LEY FEDERAL RELATIVA ES LA NORMA A TRAVÉS DE LA CUAL EL CONGRESO DE LA UNIÓN DELEGÓ SU POTESTAD TRIBUTARIA AL TITULAR DEL EJECUTIVO FEDERAL PARA REGULAR LAS MATERIAS ESTABLECIDAS EN EL ARTíCULO 131, PÁRRAFO SEGUNDO, DE LA CONSTITUCIÓN POLÍTICA DE LOS ESTADOS UNIDOS MEXICANOS. "Conforme al precepto constitucional citado, con el objeto de dotar al Estado de mecanismos jurídicos eficientes y expeditos que le permitan encauzar las operaciones de comercio internacional en beneficio de la economía nacional y responder con la diligencia necesaria a las fluctuaciones generadas en el intercambio de bienes con el sector externo, el Congreso de la Unión puede facultarle al Ejecutivo Federal aumentar, disminuir o suprimir las cuotas de las tarifas de exportación e importación. Ahora bien, si se atiende a que
} 
tienen como objeto facilitar la labor del ejecutivo como responsable de la política económica del país ${ }^{368}$, que tiene en el comercio internacional un

el artículo 40., fracción I, de la Ley de Comercio Exterior establece que el Ejecutivo Federal tiene facultades para "crear, aumentar, disminuir o suprimir aranceles, mediante decretos publicados en el Diario Oficial de la Federación, de conformidad con lo establecido en el artículo 131 de la Constitución Política de los Estados Unidos Mexicanos", resulta evidente que a través de dicha Ley el Congreso de la Unión expresamente delegó su potestad tributaria al Presidente de la República para emitir disposiciones de observancia general en materia arancelaria o no arancelaria, siguiendo los lineamientos contenidos en el precepto constitucional referido».

${ }^{368}$ Época: Novena Época. Registro: 189172. Instancia: Segunda Sala. Tipo de Tesis: Aislada. Fuente: Semanario Judicial de la Federación y su Gaceta Tomo XIV, Agosto de 2001. Materia(s): Constitucional, Administrativa. Tesis: 2a. CXV/200. Página: 211. RUBRO: COMERCIO EXTERIOR. DIFERENCIA ENTRE LAS FACULTADES FORMALMENTE LEGISLATIVAS CUYO EJERCICIO PUEDE AUTORIZAR EL CONGRESO DE LA UNIÓN AL TITULAR DEL EJECUTIVO FEDERAL EN TÉRMINOS DE LO PREVISTO EN EL PÁRRAFO SEGUNDO DEL ARTÍCULO 131 DE LA CONSTITUCIÓN FEDERAL Y LAS FACULTADES CONFERIDAS A UNA AUTORIDAD ADMINISTRATIVA AL TENOR DEL PÁRRAFO PRIMERO DEL PROPIO DISPOSITIVO CONSTITUCIONAL. Texto: “De la interpretación literal, causal y teleológica de lo dispuesto en el decreto publicado el veintiocho de marzo de mil novecientos cincuenta y uno en el Diario Oficial de la Federación, mediante el cual se modificó el artículo 49 de la Constitución Política de los Estados Unidos Mexicanos y se adicionó un párrafo segundo a su artículo 131, estableciendo una excepción al principio de división de poderes, consistente en que el presidente de la República podrá emitir actos formalmente legislativos cuando el Congreso de la Unión lo autorice para expedir disposiciones de carácter general en materia arancelaria o no arancelaria, se arriba a la conclusión de que con el objeto de dotar al Estado de mecanismos jurídicos eficientes y expeditos que le permitan encauzar las operaciones de comercio internacional en beneficio de la economía nacional y responder con la velocidad necesaria a las fluctuaciones que el intercambio de bienes con el sector externo provoca a aquélla, mediante esa reforma constitucional el Congreso de la Unión quedó facultado para autorizar al titular del Ejecutivo Federal el ejercicio de la potestad necesaria para emitir disposiciones de observancia general de la misma jerarquía que las leyes dictadas por el propio órgano legislativo en las citadas materias, para cuya emisión no se requiere seguir el proceso legislativo regulado en el artículo 72 constitucional, pero el propio Ejecutivo, al enviar "el presupuesto fiscal de cada año" debe someter a la aprobación del Congreso, el uso de dicha facultad. Ahora bien, a diferencia de estas potestades formalmente legislativas, destaca 
importante regulador y sistema de control. Sin embargo estos actos cuasi legislativos siempre estarán sujetos a la Ley, estando en un segundo término respecto de ésta ${ }^{369}$.

que en términos de lo previsto en el párrafo primero del citado artículo 131, el propio legislador federal puede otorgar a una autoridad administrativa diversas atribuciones para aplicar 10 dispuesto en un ordenamiento federal que regula el comercio exterior, lo que da lugar a que ésta emita diversos actos, ya sea con efectos generales o individualizados, que no tienen la misma jerarquía que los actos formal y materialmente legislativos que corresponde dictar a la potestad legislativa, ni pueden válidamente implicar el ejercicio de una facultad reservada constitucionalmente al Congreso de la Unión, por lo que, además, el ejercicio de estas facultades no está sujeto a la aprobación a que se refiere el párrafo segundo del último precepto constitucional mencionado».

${ }^{369}$ Época: Novena Época. Registro: 189110. Instancia: Segunda Sala. Tipo de Tesis: Aislada. Fuente: Semanario Judicial de la Federación y su Gaceta Tomo XIV, Agosto de 2001. Materia(s): Constitucional. Tesis: 2a. CXXX/2001. Página: 225. RUBRO: DIVISIÓN DE PODERES. INTERPRETACIÓN CAUSAL Y TELEOLÓGICA DE LA PROHIBICIÓN CONTENIDA EN EL TEXTO DEL ARTÍCULO 49 DE LA CONSTITUCIÓN POLÍTICA DE LOS ESTADOS UNIDOS MEXICANOS, RELATIVA A QUE EL PODER LEGISLATIVO NO PUEDE DEPOSITARSE EN UN INDIVIDUO. Texto: «Al tenor del texto original del artículo citado, cuyo párrafo segundo establecía que solamente en el caso de que el Ejecutivo de la Unión actuara en ejercicio de las facultades extraordinarias concedidas en términos de lo previsto en el artículo 29 del propio ordenamiento, el Poder Legislativo se depositaría en un solo individuo, el Congreso de la Unión emitió decretos en los que otorgó al Ejecutivo de la Unión facultades extraordinarias para legislar, entre los que destaca el expedido el ocho de mayo de mil novecientos diecisiete, mediante el cual se concedieron al presidente de la República facultades legislativas en el ramo de hacienda. Ante tal circunstancia, mediante decreto publicado el doce de agosto de mil novecientos treinta y ocho en el Diario Oficial de la Federación, el mencionado artículo 49 fue adicionado con el fin de precisar que en ningún otro caso, salvo el del diverso 29, se otorgarían al Ejecutivo facultades extraordinarias para legislar. En relación con el proceso legislativo que precedió a esta reforma constitucional, se advierte que en los dictámenes presentados por las comisiones respectivas, tanto en la Cámara de Senadores, como en la de Diputados, se enfatizó que tal reforma tenía por objeto que el Congreso de la Unión conservara incólumes las altas funciones que le encomienda la Constitución vigente, es decir, las de expedir actos formalmente legislativos, pero de ninguna manera la de emitir todas las disposiciones de observancia general, de donde se sigue que la 


\subsection{La tributación aduanera en México}

En la actualidad la tributación aduanera en México no es muy distinta al resto del mundo, dado lo prolífero de las relaciones comerciales internacionales de México, variando algunas pequeñas cosas entre ellas la terminología como veremos a lo largo de este estudio, por lo que antes de iniciar creo pertinente definir algunos conceptos tributarios y aduaneros mexicanos que pueden crear confusión respecto a los términos usados en Europa.

modificación en comento tuvo como finalidad evitar que el presidente de la República continuara expidiendo actos de aquella especial jerarquía. Posteriormente, mediante decreto publicado en el citado medio de difusión, el veintiocho de marzo de mil novecientos cincuenta y uno, se agregó un segundo párrafo al artículo 131 constitucional y, en razón de que con esta adición se dispuso que el Congreso de la Unión podría autorizar al titular del Poder Ejecutivo el ejercicio de su facultad para emitir actos formalmente legislativos en materia de comercio exterior, el Poder Revisor de la Constitución estimó necesario adicionar el referido artículo 49, con el fin de prever una segunda excepción a la referida prohibición. En tal virtud, debe estimarse que al establecerse en este último precepto constitucional que el Poder Legislativo no puede depositarse en un solo individuo, ni el Constituyente ni el Poder Revisor de la Constitución analogaron a tal poder con la función legislativa entendida como la atribución para emitir disposiciones de observancia general, sino a las facultades que constitucionalmente le están reservadas a los órganos legislativos. En ese tenor, las causas y los fines que ha tenido el Poder Revisor de la Constitución para realizar diversas adiciones al artículo 49 de la Constitución General de la República, y a otros preceptos de ésta, son reveladores de que en ella no se ha tenido la intención de impedir que las autoridades administrativas emitan disposiciones de observancia general sujetas al principio de supremacía de la ley, ni existe dispositivo constitucional que impida a las autoridades que integran los Poderes Ejecutivo o Judicial el establecimiento de normas jerárquicamente inferiores a las leyes emitidas por el Poder Legislativo". 


\begin{tabular}{|c|c|c|}
\hline $\begin{array}{l}\text { Concepto en el } \\
\text { Derecho } \\
\text { Mexicano }\end{array}$ & $\begin{array}{l}\text { Equivalente en } \\
\text { el Derecho } \\
\text { Europeo }\end{array}$ & Definición en el Derecho mexicano \\
\hline Contribución & Tributo & $\begin{array}{l}\text { No existe una definición concreta en la legislación sin } \\
\text { embargo el artículo } 1^{\circ} \text { del Código fiscal de la federación } \\
\text { establece: «Artículo 10.- Las personas físicas y las } \\
\text { morales, están obligadas a contribuir para los gastos } \\
\text { públicos conforme a las leyes fiscales respectivas. Las } \\
\text { disposiciones de este Código se aplicarán en su defecto y } \\
\text { sin perjuicio de lo dispuesto por los tratados internacionales } \\
\text { de los que México sea parte. Sólo mediante ley podrá } \\
\text { destinarse una contribución a un gasto público específico. } \\
\text { La Federación queda obligada a pagar contribuciones } \\
\text { únicamente cuando las leyes lo señalen expresamente. Los } \\
\text { estados extranjeros, en casos de reciprocidad, no están } \\
\text { obligados a pagar impuestos. No quedan comprendidas en } \\
\text { esta exención las entidades o agencias pertenecientes a } \\
\text { dichos estados. Las personas que de conformidad con las } \\
\text { leyes fiscales no estén obligadas a pagar contribuciones, } \\
\text { únicamente tendrán las otras obligaciones que establezcan } \\
\text { en forma expresa las propias leyes». }\end{array}$ \\
\hline Crédito Fiscal & $\begin{array}{l}\text { Deuda } \\
\text { tributaria y/o } \\
\text { Deuda } \\
\text { Aduanera }\end{array}$ & $\begin{array}{l}\text { Código fiscal de la Federación, Artículo } 4^{\circ} \text { «Son créditos } \\
\text { fiscales los que tenga derecho a percibir el Estado o sus } \\
\text { organismos descentralizados que provengan de } \\
\text { contribuciones, de sus accesorios o de aprovechamientos, } \\
\text { incluyendo los que deriven de responsabilidades que el } \\
\text { Estado tenga derecho a exigir de sus funcionarios o } \\
\text { empleados o de los particulares, así como aquellos a los } \\
\text { que las leyes les den ese carácter y el Estado tenga } \\
\text { derecho a percibir por cuenta ajena». }\end{array}$ \\
\hline Derechos & Tasas & $\begin{array}{l}\text { Código fiscal de la Federación, Artículo } 2^{\circ} \text {, fracción IV. «IV. } \\
\text { Derechos son las contribuciones establecidas en Ley por el } \\
\text { uso o aprovechamiento de los bienes del dominio público }\end{array}$ \\
\hline
\end{tabular}




\begin{tabular}{|l|l|l|}
\hline $\mid$ & $\begin{array}{l}\text { de la Nación, así como por recibir servicios que presta el } \\
\text { Estado en sus funciones de derecho público, excepto } \\
\text { cuando se presten por organismos descentralizados u } \\
\text { órganos desconcentrados cuando en este último caso, se } \\
\text { trate de contraprestaciones que no se encuentren previstas } \\
\text { en la Ley Federal de Derechos. También son derechos las } \\
\text { contribuciones a cargo de los organismos públicos } \\
\text { descentralizados por prestar servicios exclusivos del } \\
\text { Estado". }\end{array}$ \\
\hline
\end{tabular}

Para esta investigación nos centraremos en el Impuesto General de importación (IGI), que es el de mayor relevancia, además de que conjuntamente con el impuesto general de exportación, son los únicos a los que hace referencia expresa la Ley aduanera en su artículo $51^{370}$. Lo cual no significa que sean los únicos tributos a la importación en México, pues también se pueden causar el Impuesto al Valor Agregado, el Impuesto Sobre Automóviles Nuevos, el Impuesto Especial sobre Producción y Servicios y el Derecho de Trámite Aduanero ${ }^{371}$.

370 «ARTICULO 51. Se causarán los siguientes impuestos al comercio exterior:

I. General de importación, conforme a la tarifa de la ley respectiva.

II. General de exportación, conforme a la tarifa de la ley respectiva».

${ }^{371}$ Los Derechos de trámite aduanero, son tasas que se cobran por las operaciones aduaneras que se efectúen utilizando un pedimento (declaración) o el documento aduanero correspondiente, Tributo que ha sido declarado inconstitucional por la Suprema Corte de Justicia de la Nación, mediante jurisprudencia de Novena Época. Registro: 174268. Instancia: Segunda Sala. Tipo de Tesis: Jurisprudencia. Fuente: Semanario Judicial de la Federación y su Gaceta Tomo XXIV, Septiembre de 2006. Materia(s): Constitucional, Administrativa. Tesis: 2a./J. 122/2006. Página: 263. RUBRO: DERECHO DE TRÁMITE ADUANERO. EL ARTíCULO 
El artículo 52 de la Ley Aduanera establece genéricamente el hecho imponible de la tributación aduanera en México bajo los siguientes términos: «Están obligadas al pago de los impuestos al comercio exterior y al cumplimiento de las regulaciones y restricciones no arancelarias y otras medidas de regulación al comercio exterior, las personas que introduzcan mercancías al territorio nacional o las extraigan del mismo, incluyendo las que estén bajo algún programa de devolución o diferimiento de aranceles en los casos previstos en los artículos 63-A, 108, fracción III y 110 de esta Ley».

Nuevamente hablamos de un hecho imponible genérico en tanto existen hechos imponibles específicos como es la importación definitiva y la temporal, existiendo variantes de esta última. Así pues, igual que como lo hicimos con el Derecho europeo, lo haremos ahora con el Derecho mexicano, partiendo del análisis del hecho imponible genérico.

49, FRACCIÓN I, DE LA LEY FEDERAL RELATIVA, EN VIGOR A PARTIR DEL 10. DE ENERO DE 2005, ES INCONSTITUCIONAL. Sin embargo dada la relatividad de las sentencias del juicio de amparo en México, la declaratoria de inconstitucionalidad de la norma no da lugar a la anulación de la ley con efectos erga omnes, sino que protege únicamente al individuo que pidió la protección Constitucional, por lo cual se sigue cobrando pese a declaratoria de inconstitucionalidad. Tema que podría ser abordado con mayor profundada en otro trabajo. 


\subsubsection{El hecho imponible genérico de la tributación aduanera en México y su naturaleza jurídico-tributaria.}

La construcción del hecho imponible propuesta por el artículo 51 de la Ley Aduanera (LA), coincide con la ya expuesta definición de importación dada por el glosario de términos aduaneros de la $\mathrm{OMC}$, en la que se considera la importación como «el acto de introducir o de actuar para que se introduzca en un territorio aduanero cualquier mercancía» ${ }^{372}$.

CARVAJAL CONTRERAS y RHODE PONCE ${ }^{373}$ hacen una interpretación restrictiva y literal del artículo 51 de la Ley Aduanera, atendiendo al principio

\footnotetext{
${ }^{372}$ World Customs Organization.Glossary of International Customs Terms. Bruselas, 2006. P.16 «Importation: The act of bringing or causing any goods to be brought into a Customs territory».

${ }^{373}$ CARVAJAL CONTRERAS, M. Derecho aduanero. 15aㅗ Ed. México: Porrúa, 2009, p. 386 «Hecho generador, es el momento en que nace la obligación tributaria. Existen dos criterios para fijarlo: a) Criterio político -geográfico, consistente en el paso de las mercancías a través de las fronteras aduaneras; en la importación será cuando se introduzcan las mercancías extranjeras al territorio aduanero; en la exportación, es la salida de las mercancías nacionales o nacionalizadas del territorio aduanero. B) Criterio económico, es cuando se da la intención integradora, es decir, en la importación, aquella que tiene como objetivo integrar la mercancía al consumo interno del país; en la exportación la salida de mercancías del circuito interno del consumo del país. Nuestro país sigue el criterio político-geográfico, de acuerdo a nuestra opinión, en forma equivocada, ya que pensamos que el criterio económico es el adecuado; por ser en este momento en que se manifiesta el acto o hecho jurídico que de acuerdo con la ley condiciona la obligación de pago de los impuestos al comercio exterior». RHODE PONCE, A. Derecho aduanero mexicano 2. Regímenes, contribuciones y procedimientos aduaneros. $1^{\stackrel{a}{a}}$ Ed. México: Ediciones fiscales ISEF, 2009, P. 240 «En la legislación mexicana, el artículo 52 de la NLA adopta el criterio objetivo cuando dispone que están obligados al pago de los impuestos al comercio exterior las personas que introduzcan mercancías al territorio nacional o los extraigan del mismo, teniendo esta disposición consecuencias bien importantes, por cuanto que los regímenes aduaneros diferentes a los definitivos serán de carácter suspensivos 0
} 
establecido en el artículo 5 del Código Fiscal de la Federación ${ }^{374}$, donde identifican el hecho imponible del IGI como la simple introducción de la mercancía al territorio nacional, no obstante CARVAJAL se pronuncia aduciendo que lo doctrinalmente correcto sería decantarse por la integración económica de la mercancía.

Como analizamos en el capítulo II, el simple paso de la mercancía no puede ser considerado como objeto de tributación. Si bien la Ley Aduanera establece como objeto de tributación la entrada de mercancía al territorio nacional, del estudio sistemático ${ }^{375}$ de la Ley aduanera se desprende que esto no es así,

condicionantes del pago de las contribuciones, pero ellas ya se habrán causado con el traspaso de las fronteras del territorio nacional».

${ }^{374}$ CFF. «Artículo 50.- Las disposiciones fiscales que establezcan cargas a los particulares y las que señalan excepciones a las mismas, así como las que fijan las infracciones y sanciones, son de aplicación estricta. Se considera que establecen cargas a los particulares las normas que se refieren al sujeto, objeto, base, tasa o tarifa. Las otras disposiciones fiscales se interpretarán aplicando cualquier método de interpretación jurídica. A falta de norma fiscal expresa, se aplicarán supletoriamente las disposiciones del derecho federal común cuando su aplicación no sea contraria a la naturaleza propia del derecho fiscal»».

${ }^{375}$ De acuerdo a la Jurisprudencia de la SCJN la interpretación sistemática no rompe con el principio de interpretación y aplicación estricta de las leyes fiscales que contempla el artículo $5^{\circ}$ del Código fiscal de la federación. Ver al respecto: Época: Octava Época. Registro: 389668. Instancia: Tercera Sala. Tipo de Tesis: Jurisprudencia. Fuente: Apéndice de 1995. Tomo I, Parte SCJN. Materia(s): Constitucional. Tesis: 215. Página: 206. RUBRO: LEYES FISCALES. LA INTERPRETACION SISTEMATICA DE SUS NORMAS NO CONTRAVIENE LOS PRINCIPIOS DE INTERPRETACION Y APLICACION ESTRICTA Y DE LEGALIDAD QUE RIGEN EN DICHA MATERIA. Texto: «Si bien es cierto que la interpretación y aplicación de las normas impositivas es estricta, también es cierto que resultaría imposible interpretar cada precepto considerándolo fuera del contexto normativo del que forma parte, ya que de ser así, cualquier intento estricto de interpretación resultaría infructuoso para determinar el sentido y alcance de las normas. Toda norma requiere de una interpretación, aunque sea literal, sin importar su rango, ya sea constitucional, legal, reglamentario, contractual o de cualquier otra 
pues no toda introducción de mercancías al territorio nacional hace que surja la obligación de pago del impuesto de importación.

Al respecto, el artículo 61 de la ley en mención establece que «No se pagarán los impuestos al comercio exterior por la entrada al territorio nacional o la salida del mismo de las siguientes mercancías", y acto seguido da un extenso listado de 18 tipos de mercancías que se encuentran exentas del pago de tributos al comercio exterior y que tienen como común denominador que por su naturaleza, valor, cantidad o finalidad no son sujetos de comercio.

Con lo anterior se demuestra que no es el simple cruce de fronteras lo que provoca el nacimiento de la deuda tributaria sino que, al igual que en el caso europeo, es evidente que la integración de la mercancía a la economía nacional $\left.\right|^{376}$, es el elemento objetivo del hecho imponible genérico y que opera,

índole, y un principio de hermenéutica obliga a interpretar los preceptos jurídicos en función a los demás que integran el ordenamiento al que pertenecen, y en función a los demás ordenamientos que integran un determinado régimen jurídico; sin que ello implique que en materia impositiva una interpretación estricta pero al fin y al cabo interpretación, vaya a obligar al sujeto pasivo de la norma tributaria al pago de contribuciones no establecidas en las leyes fiscales. En consecuencia, interrelacionar las normas de manera sistemática no viola el principio de interpretación y aplicación estricta que rige la materia fiscal, ni el principio de legalidad que prevalece en dicha materia, de acuerdo con el artículo 31, fracción IV, constitucional».

376 GARRE, F. El hecho imponible en el impuesto aduanero. $1^{\text {a }}$ Ed. México: Centro De Investigación Aduanera y de Comercio Internacional, 1999. P.62 «La importación no es, simplemente, el paso de la línea aduanera; la importación es un hecho que produce determinados efectos y situaciones económicas, como o es la incorporación de la mercancía a la economía nacional» 
como veremos más adelante, en todos y en cada uno de los supuestos específicos que contempla la Ley Aduanera ${ }^{377}$.

\subsubsection{El “impuesto” en México. Aspectos generales.}

Si bien en nuestro sistema jurídico los derechos arancelarios son denominados impuestos, esto no significa necesariamente que su naturaleza jurídica corresponda a este tipo de tributos.

El artículo 2 del Código fiscal de la federación hace una clasificación de las contribuciones (tributos), en los siguientes términos:

377 En este sentido además del ya citado CARVAJAL CONTRERAS, encontramos las opiniones de GARCIA, T. y RÍOS, G. "Diferencias entre impuestos aduaneros de importación y cuotas compensatorias del comercio exterior mexicano, en el ámbito del derecho tributario. Reflexiones sobre la constitucionalidad de las mismas". Boletín mexicano de derecho comparado. Número 91 Enero-Abril 1998. "Una vez hecho el apuntamiento anterior, es necesario señalar que en la doctrina y legislación mexicana, a la realización en concreto de la hipótesis normativa se le denomina hecho generador o hecho imponible. En el caso de los impuestos de importación, el hecho imponible es la entrada legal de la mercancía al país o su importación. Pero, en términos legales, ¿qué significa importación? Según la doctrina jurídica, este concepto va más allá de la entrada física de los bienes al territorio sometido a gravamen, es decir, comprende dos momentos: 1) la admisión de la entrada por parte de la administración competente, y 2) la vocación de la incorporación permanente de los bienes al mercado interior, esto es, su destino a los procesos productivos o al consumo. Es importante destacar que la importación requiere del animus de incorporar definitivamente las mercancías al mercado interior; en consecuencia, si no existiese dicho animus no se provoca la importación, aunque las mercancías estén físicamente en espacio aduanero». WITKER,J. Derecho tributario aduanero. 2ª Ed. México: UNAM, Instituto de Investigaciones Jurídicas, 1999, P. 80 «En efecto, sabemos que lo que se grava es la importación, entendiendo por tal la introducción legal de mercancías procedentes del exterior para su uso o consumo definitivo en el país». Opiniones con las que concordamos de forma parcial pues la definitividad no es un elemento determinante para el surgimiento de la obligación tributaria como veremos más adelante. 
«Artículo 2.- Las contribuciones se clasifican en impuestos, aportaciones de seguridad social, contribuciones de mejoras y derechos, las que se definen de la siguiente manera:

I. Impuestos son las contribuciones establecidas en ley que deben pagar las personas físicas y morales que se encuentran en la situación jurídica o de hecho prevista por la misma y que sean distintas de las señaladas en las fracciones II, III y IV de este Artículo.

II. Aportaciones de seguridad social son las contribuciones establecidas en ley a cargo de personas que son sustituidas por el Estado en el cumplimiento de obligaciones fijadas por la ley en materia de seguridad social o a las personas que se beneficien en forma especial por servicios de seguridad social proporcionados por el mismo Estado.

III. Contribuciones de mejoras son las establecidas en Ley a cargo de las personas físicas y morales que se beneficien de manera directa por obras públicas.

IV. Derechos son las contribuciones establecidas en Ley por el uso o aprovechamiento de los bienes del dominio público de la Nación, así como por recibir servicios que presta el Estado en sus funciones de derecho público, excepto cuando se presten por organismos descentralizados u órganos desconcentrados cuando en este último caso, se trate de contraprestaciones que no se encuentren previstas 
en la Ley Federal de Derechos. También son derechos las contribuciones a cargo de los organismos públicos descentralizados por prestar servicios exclusivos del Estado».

De entrada encontramos una infortunada y escueta definición del impuesto, pues la única diferenciación objetiva que hace respecto de las otras contribuciones es que sea diferente a las otras listadas, pues las demás características son comunes a todos los tributos, por lo que prácticamente deja indefinido el concepto de impuesto.

La jurisprudencia hasta la $8^{\text {a }}$ Época no abonaba mucho respecto de los elementos esenciales de los impuestos, estableciendo tres requisitos básicos que son: el estar contenido en ley, ser proporcionales y tener por objeto la financiación del gasto público ${ }^{378}$; dando una definición más bien de tributo que

${ }^{378}$ Época: Séptima. Registro: 232308. Instancia: Pleno. Tipo de Tesis: Jurisprudencia. Fuente: Semanario Judicial de la Federación, Volumen 187-192, Primera Parte. Página: 111. Materia(s): Constitucional, Administrativa. RUBRO: IMPUESTOS, VALIDEZ CONSTITUCIONAL DE LOS. Texto: “De acuerdo con el artículo 31, fracción IV, de la Carta Magna, para la validez constitucional de un impuesto se requiere la satisfacción de tres requisitos fundamentales; primero, que sea establecido por ley; segundo, que sea proporcional y equitativo, y tercero, que se destine al pago de los gastos públicos. Si falta alguno de estos tres requisitos, necesariamente el impuesto será contrario a lo estatuido por la Constitución General. Ahora bien, aun cuando respecto de los requisitos de proporcionalidad y equidad, este Tribunal Pleno no ha precisado una fórmula general para determinar cuándo un impuesto cumple dichos requisitos, que traducidos de manera breve quieren decir de justicia tributaria, en cambio, de algunas de las tesis que ha sustentado, pueden desprenderse ciertos criterios. Así se ha sostenido, que, si bien el artículo 31 de la Constitución, que establece los requisitos de proporcionalidad y equidad como derecho de todo contribuyente, no está en el capítulo relativo a las garantías individuales, la lesión de este derecho sí es una violación de garantías cuando los tributos que decreta el Poder Legislativo son notoriamente exorbitantes y ruinosos. También este Tribunal Pleno ha considerado que la equidad exige que se respete el principio 
de impuesto, pues al igual que el Código enumeraba elementos esenciales de todo tributo que no hacen distingo alguno entre ellos. En la 9a Época aumenta un cuarto elemento que se desprende del de proporcionalidad, exigiendo que «todos los presupuestos de hecho de los impuestos deben tener una naturaleza económica en forma de una situación o de un movimiento de riqueza» ${ }^{379}$. En el 2006, la SCJN emite una nueva jurisprudencia por contradicción de tesis en la que el pleno de la SCJN analiza la naturaleza jurídica de una contribución en específico que se cobraba en el Distrito

de igualdad, determinando que es norma de equidad la de que se encuentren obligados a determinada situación los que se hallen dentro de lo establecido por la ley y que no se encuentren en esa misma obligación los que están en situación jurídica diferente o sea, tratar a los iguales de manera igual. Es decir, este Tribunal Pleno ha estimado que se vulnera el derecho del contribuyente a que los tributos sean proporcionales y equitativos, cuando el gravamen es exorbitante y ruinoso y que la equidad exige que se respete el principio de igualdad».

${ }^{379}$ Época: Novena Época. Registro: 192849. Instancia: Pleno. Tipo de Tesis: Jurisprudencia. Fuente: Semanario Judicial de la Federación y su Gaceta, Tomo X, Noviembre de 1999. Materia(s): Constitucional, Administrativa. Tesis: P./J. 109/99. Página: 22. RUBRO: CAPACIDAD CONTRIBUTIVA. CONSISTE EN LA POTENCIALIDAD REAL DE CONTRIBUIR A LOS GASTOS PÚBLICOS. Texto: "Esta Suprema Corte de Justicia de la Nación, ha sostenido que el principio de proporcionalidad tributaria exigido por el artículo 31, fracción IV, de la Constitución Política de los Estados Unidos Mexicanos, consiste en que los sujetos pasivos de un tributo deben contribuir a los gastos públicos en función de su respectiva capacidad contributiva. Lo anterior significa que para que un gravamen sea proporcional, se requiere que el hecho imponible del tributo establecido por el Estado, refleje una auténtica manifestación de capacidad económica del sujeto pasivo, entendida ésta como la potencialidad real de contribuir a los gastos públicos. Ahora bien, tomando en consideración que todos los presupuestos de hecho de los impuestos deben tener una naturaleza económica en forma de una situación o de un movimiento de riqueza y que las consecuencias tributarias son medidas en función de esta riqueza, debe concluirse que es necesaria una estrecha relación entre el hecho imponible y la base gravable a la que se aplica la tasa o tarifa del impuesto". 
Federal ${ }^{380}$. Pero más allá del resultado final nos interesan los parámetros que utilizó la Corte para determinar la naturaleza impositiva de la contribución, los cuales podemos resumir en los siguientes puntos:

1. El hecho imponible lo realiza directamente el particular;

2. se constituye sobre actos que reflejan una disponibilidad económica;

${ }^{380}$ Época: Novena Época. Registro: 175077. Instancia: Segunda Sala. Tipo de Tesis: Jurisprudencia. Fuente: Semanario Judicial de la Federación y su Gaceta Tomo XXIII, Mayo de 2006. Materia(s): Constitucional, Administrativa. Tesis: 2a./J. 54/2006. Página: 281. RUBRO: IMPUESTOS. TIENEN ESA NATURALEZA LAS PRESTACIONES PÚBLICAS PATRIMONIALES PREVISTAS EN LOS ARTÍCULOS 318 Y 319 DEL CÓDIGO FINANCIERO DEL DISTRITO FEDERAL Y, POR TANTO, DEBEN CUMPLIR CON LOS PRINCIPIOS TRIBUTARIOS CONSAGRADOS EN EL ARTíCULO 31, FRACCIÓN IV, DE LA CONSTITUCIÓN FEDERAL. Texto: «Los artículos citados establecen que quienes construyan desarrollos habitacionales de más de 20 viviendas, o realicen obras, instalaciones 0 aprovechamientos de más de 200 metros cuadrados, deberán cubrir el pago por concepto de aprovechamientos para que la autoridad competente realice las acciones necesarias para prevenir, mitigar o compensar las alteraciones o afectaciones al ambiente y los recursos naturales, así como los efectos del impacto vial, a razón de una determinada cantidad por metro cuadrado de construcción, en el caso de los desarrollos mencionados, y conforme a las cantidades que se determinen por metro cuadrado de construcción, según la zona en que se realice la obra y el destino que se le dé, tratándose de construcciones de más de 200 metros cuadrados. En ese tenor, se concluye que aun cuando los artículos 318 y 319 del Código Financiero del Distrito Federal señalen que las prestaciones patrimoniales de carácter público que prevén se cubrirán en concepto de aprovechamientos, lo cierto es que tienen la naturaleza de un impuesto $y$, por ende, están sujetas al cumplimiento de los principios tributarios contenidos en el artículo 31, fracción IV, de la Constitución Política de los Estados Unidos Mexicanos, en virtud de que son impuestas en forma unilateral y coactiva por el Distrito Federal; el hecho imponible lo realiza directamente el particular, que es la referida construcción o realización de obras, instalaciones o aprovechamientos, y se constituye sobre actos que reflejan una disponibilidad económica como consecuencia de la propiedad o posesión inmobiliaria, además de que no se vincula a la realización de un acto o actividad específicos a cargo de la administración pública local, ya que si ésta no realiza las acciones referidas, de cualquier forma nace la obligación tributaria y, por último, esas acciones constituyen gastos públicos indivisibles e indeterminados individualmente». 
3. no se vincula a la realización de un acto o actividad específicos a cargo de la administración pública;

4. tiene como fin la financiación del gasto público.

El ámbito doctrinal mexicano no se aparta mucho de los preceptos vertidos por las jurisprudencias de la SCJN, por el contrario son coincidentes en casi su totalidad aportando algunos matices extras.

DE LA GARZA define los impuestos agrupando gran parte de los conceptos descritos por la jurisprudencia, conceptualizando al impuesto como «una prestación en dinero o en especie de naturaleza tributaria, ex - lege, cuyo presupuesto es un hecho o una situación jurídica que no constituye una actividad del Estado referida al obligado y destinada a cubrir los gastos públicos» ${ }^{381}$.

JIMÉNEZ GONZÁLEZ afirma «que no puede haber impuesto sino hay poder imperio, si el producto de su recaudación no tiene como fin primordial la cobertura del gasto público y si el hecho generador de la obligación de su pago no es ajeno a cualquier conducta del Estado»382. En el mismo sentido QUINTANA VALTIERRA y ROJAS YÁÑEZ, siguiendo a GIULANI FONROUGE, establecen los siguientes caracteres distintivos del impuesto:

«a) Una obligación de dar dinero o cosas (prestación), si bien en la actualidad es predominantemente pecuniaria; b) emanada del poder de imperio estatal, lo

\footnotetext{
${ }^{381}$ DE LA GARZA, S.F. Derecho financiero mexicano. 28ª Ed. México: Porrúa, 2010, p. 363 382 JIMÉNEZ GONZÁLEZ, A. Curso de derecho tributario. 1a Ed. México: Tax editores, 2014, p. 101
} 
que supone su obligatoriedad y la conclusión de hacer efectivo su cumplimiento; c) establecida por la ley; d) aplicable a personas individuales o colectivas; e) que se encuentren en las más variadas situaciones predecibles, como pueden ser determinada capacidad económica, realización de ciertos actos, etcétera» ${ }^{383}$.

De las jurisprudencias y definiciones expuestas anteriormente, podemos deducir que en el Derecho mexicano el impuesto debe de cumplir con los siguientes elementos esenciales:

1) Prestación Pecuniaria en dinero o en especie;

2) Ex - lege;

3) El hecho imponible siempre debe de ser de naturaleza económica en forma de una situación o de un movimiento de riqueza, que reflejen autentica capacidad contributiva;

4) El presupuesto es un hecho o una situación jurídica que no constituye una actividad del Estado referida al obligado, o por la cual el obligado obtiene algún tipo de beneficio en forma de contraprestación.

5) Financiación del gasto público.

383 QUINTANA VALTIERRA, J. y ROJAS YÁÑEZ, J. Derecho tributario mexicano. 5a Ed. México: Trillas,2008, p. 61 


\subsubsection{La naturaleza jurídico-tributaria del hecho imponible genérico.}

Una vez definidos los elementos esenciales del impuesto en México, es procedente indagar si el impuesto general a la importación cumple con los elementos necesarios para ser considerado dentro de esa categoría tributaria, conforme a lo dispuesto en los puntos anteriores:

a) En cuanto al primer y segundo requisito no existe problema alguno en acreditarlos, en tanto el IGI consiste en una prestación dineraria establecida en la Ley aduanera por motivo de la importación de una mercancía.

b) El debate inicia al tratar de encuadrar el IGI en el tercer punto, es decir en el de encuadrar el hecho imponible con una situación económica reveladora de capacidad económica, pues como vimos en el caso europeo no es una situación fácil de demostrar desde la postura impositiva.

La segunda Sala de la SCJN emitió una tesis aislada considerando que el IGI cumple con el principio de proporcionalidad atendiendo a «que la base gravable del impuesto general de importación, es decir, que el valor en aduana será el valor de transacción de las mercancías, entendiéndose por éste el precio pagado por las mercancías a importar, el cual se ajustará, en su caso, en términos del segundo de los artículos citados, no transgreden el principio de proporcionalidad tributaria contenido en el artículo 31, fracción IV, de la Constitución Política de los Estados Unidos Mexicanos, porque atienden a la capacidad contributiva del sujeto obligado al permitir ajustar la base del 
impuesto a los valores y precios reales de las operaciones aduaneras, pues si bien es cierto que para determinar el valor de transacción se incluyen los conceptos incrementables previstos en el mencionado artículo 65, como son, entre otros, los gastos y los riesgos del transporte internacional y del seguro, vinculados con los "Incoterms 2000", es decir, los criterios internacionales que definen y reparten claramente las obligaciones, los gastos y los riesgos del transporte internacional y del seguro entre el importador y el exportador, también lo es que permiten excluir los gastos decrementables a que se refiere el numeral $66 \mathrm{del}$ mismo ordenamiento legal, lo cual implica que la base del impuesto sea acorde al costo que efectivamente significó para el importador la introducción de la mercancía al país, cuyos términos convino libremente con su vendedor ${ }^{384}$.

En cuanto al estudio que realiza la Segunda Sala estamos parcialmente de acuerdo, pues si bien la determinación de la base imponible cumple en parte el buscar un aspecto económico, sigue siendo un estudio parcial para determinar la proporcionalidad del impuesto, pues no toda importación es sujeta a la imposición, además de que el tipo aplicable ${ }^{385}$, no se determina por el mayor o

${ }^{384}$ Época: Novena Época. Registro: 169484. Instancia: Segunda Sala. Tipo de Tesis: Aislada. Fuente: Semanario Judicial de la Federación y su Gaceta Tomo XXVII, Junio de 2008. Materia(s): Constitucional, Administrativa. Tesis: 2a. LXXVI/2008. Página: 446.RUBRO: IMPUESTO GENERAL DE IMPORTACIÓN. LOS ARTÍCULOS 64, TERCER PÁRRAFO, Y 65 DE LA LEY ADUANERA VIGENTE A PARTIR DEL 10. DE ABRIL DE 1996, NO TRANSGREDEN EL PRINCIPIO DE PROPORCIONALIDAD TRIBUTARIA.

${ }^{385}$ Época: Novena Época. Registro: 167414. Instancia: Pleno. Tipo de Tesis: Jurisprudencia. Fuente: Semanario Judicial de la Federación y su Gaceta. Tomo XXIX, Abril de 2009. Materia(s): Constitucional, Administrativa. Tesis: P./J. 6/2009. Página: 1130. RUBRO: PROPORCIONALIDAD TRIBUTARIA. SU ANÁLISIS EN RELACIÓN CON LA TASA DE LOS 
menor coste de la mercancía, sino por el tipo, origen y necesidades del mercado interior de la mercancía, es decir, por el impacto económico que produzca la mercancía en el mercado interno, lo cual de ninguna forma es denotativo de la capacidad contributiva que es exigible a todos los impuestos.

Una mercancía estará sujeta al pago del IGI cuando cumpla los siguientes requisitos:

- Que pueda ser material y jurídicamente sujeto de comercio.

- Que esté en disposición real de ser sujeto de uso, consumo o venta, en el mercado interior.

- La mayor o menor necesidad en el mercado de la mercancía, pues a mayor necesidad menor imposición (inclusive exención total), a menor necesidad mayor proteccionismo, por lo tanto mayor imposición.

- El origen de las mercancías. (La existencia o inexistencia de acuerdos comerciales con el país de origen).

IMPUESTOS INDIRECTOS. Texto: «El análisis de la proporcionalidad tributaria prevista en el artículo 31, fracción IV, de la Constitución Política de los Estados Unidos Mexicanos, una vez determinada la naturaleza de la contribución, debe hacerse en función de sus elementos cuantitativos como la tasa imponible, cuya elección por parte del legislador ordinario no puede quedar al margen de regularidad constitucional, aunque se trate de impuestos indirectos en los que se repercute la carga fiscal y dependen de la absorción del mercado, ya que el monto de la tasa impositiva no puede llegar al extremo de impedir el ejercicio de las libertades humanas, de los diferentes bienes que permiten desarrollarse, o poner en riesgo la eficacia de un principio o postulado de la propia Constitución, es decir, el porcentaje, cifra o coeficiente que se aplicará a la base imponible no debe ir más allá de los límites constitucional y razonablemente permitidos. Además, el tipo de tasa debe ser coherente con la naturaleza del tributo, pues su idoneidad a la clase de contribución es un elemento toral para establecer si con ello se vulnera o no el principio de proporcionalidad tributaria, pues lo contrario implicaría validar el tipo de tasa elegida aunque sea incorrecta por alejarse de aquella naturaleza». 
Pues bien, en estos conceptos no se encuentra movimiento de riqueza, siendo evidente que la sujeción a la imposición, así como los elementos para determinar la deuda aduanera, no tienen como origen la capacidad contributiva desde la perspectiva impositiva, por lo que al igual que en el hecho imponible genérico europeo, en el caso mexicano es imposible el ubicarlo en la categoría de impuesto.

c) La actividad del Estado en la realización del hecho imponible de importación y/o contraprestación a favor del obligado.

Si entendemos importación como la simple entrada o salida de mercancías del territorio nacional, estaría por demás claro la inexistencia de actividad del Estado en la realización del hecho imponible; mas ha quedado demostrado en esta investigación que el simple paso de la mercancía por la línea aduanera no genera obligación alguna, y no es hasta que la mercancía se encuentra en posibilidades de ser sujeta a consumo o comercialización, cuando nace la obligación de pago del tributo. Supuesto que, al igual que en el caso europeo, no se da siempre por la vía legal, lo que no impide el que nazca la obligación tributaria ${ }^{386}$, por lo que desde la perspectiva genérica no es posible el determinar la existencia de una actividad del Estado en forma de un servicio.

\footnotetext{
${ }^{386}$ Código Fiscal de la Federación Artículo 70.- «La aplicación de las multas, por infracciones a las disposiciones fiscales, se hará independientemente de que se exija el pago de las contribuciones respectivas y sus demás accesorios, así como de las penas que impongan las autoridades judiciales cuando se incurra en responsabilidad penal».
} 
No obstante es evidente, como ya se mencionó con anterioridad, la necesaria participación del Estado en la conservación y estabilidad del bien público denominado mercado, en el que se incorporan las mercancías. En cuanto a la existencia de contraprestación a favor del obligado, está se puede concebir por el uso que hace el obligado del mercado, mediante la integración de una mercancía exógena al circuito económico nacional, como analizaremos más adelante.

d) Financiación del gasto público. En este punto no existe controversia en tanto es común a todos los ingresos públicos el fin primordial de financiar el gasto público.

En conclusión, al no cumplir los requisitos esenciales del impuesto -un presupuesto de hecho revelador de capacidad económica y la ausencia de contraprestación- es imposible ubicar el gravamen a la importación dentro de la categoría de impuestos, por lo que, al igual que en el caso europeo, considero que nos encontramos ante un derecho (tasa) por utilización especial de un bien de dominio público, atendiendo a los razonamientos que veremos en los párrafos siguientes.

La consideración del tributo a la importación como Derecho (tasa) por utilización de un bien de dominio público ha de partir, con carácter preliminar, de lo establecido en el art. $2^{\circ}$ del Código Fiscal de la Federación. 
El artículo $2^{\circ}$ del Código Fiscal de la Federación en su fracción IV, dicta que los «Derechos son las contribuciones establecidas en Ley por el uso o aprovechamiento de los bienes del dominio público de la Nación, así como por recibir servicios que presta el Estado en sus funciones de derecho público, excepto cuando se presten por organismos descentralizados u órganos desconcentrados cuando en este último caso, se trate de contraprestaciones que no se encuentren previstas en la Ley Federal de Derechos. También son derechos las contribuciones a cargo de los organismos públicos descentralizados por prestar servicios exclusivos del Estado».

Así pues tendríamos que comenzar por establecer qué se entiende por bien de dominio público en el derecho mexicano y si la economía en general y el mercado en particular forman parte de él. El artículo 27 Constitucional es considerado tradicionalmente el fundamento por el que se instituye el patrimonio de la federación, en tanto determina la propiedad de la nación sobre: tierras, aguas, recursos naturales, minerales, hidrocarburos y espacio aéreo $^{387}$.

\footnotetext{
387 CPEUM «Artículo 27. La propiedad de las tierras y aguas comprendidas dentro de los límites del territorio nacional, corresponde originariamente a la Nación, la cual ha tenido y tiene el derecho de transmitir el dominio de ellas a los particulares, constituyendo la propiedad privada (...)». Transcribimos solo el primer párrafo, pues este artículo es uno de los más extensos de la Constitución mexicana, ya que también regula de forma extensa la posesión de la tierra y la prohibición de latifundios.
} 
Sin embargo el artículo no abarca la totalidad de bienes patrimoniales del Estado pues, contrario al pensamiento de FRAGA ${ }^{388}$ quien considera que el patrimonio del Estado está formado únicamente por bienes materiales, resulta evidente que no es así, ya que como deja en claro la Jurisprudencia ${ }^{389}$ y otros autores como ACOSTA ROMERO, DELGADILLO GUTIÉREZ y SERRA ROJAS $^{390}$, el patrimonio de la federación está constituido por bienes tangibles e

${ }^{388}$ FRAGA, G. Derecho administrativo. 48ª Ed. México: Porrúa, 2012, P. 343 «El conjunto de bienes materiales que de modo directo o indirecto sirven al Estado para realizar sus atribuciones constituye el dominio o patrimonio del propio Estado».

${ }^{389}$ Época: Décima Época. Registro: 2001705.Instancia: Tribunales Colegiados de Circuito. Tipo de Tesis: Aislada. Fuente: Semanario Judicial de la Federación y su Gaceta. Libro XII, septiembre de 2012, Tomo 3. Materia(s): Administrativa. Tesis: I.1o.(I Región) 13 A (10a.) Página: 1938. RUBRO: PAISAJE URBANO. CONSTITUYE UN BIEN INTANGIBLE DEL DOMINIO PÚBLICO, DE CONFORMIDAD CON LA LEY DE PUBLICIDAD EXTERIOR DEL DISTRITO FEDERAL. Texto: «De acuerdo con el artículo 2 de dicha legislación, el paisaje urbano es el aspecto que ofrecen las edificaciones y los demás elementos culturales que hacen posible la vida en común de los ciudadanos, así como el entorno natural en el que se insertan; en tanto que el espacio público está constituido por las calles, paseos, plazas, parques, jardines y demás lugares de encuentro de las personas, por lo que debe ser considerado un punto de convivencia que merece cuidado y preservación constante. De lo anterior se concluye que el paisaje urbano está indisolublemente vinculado al espacio público y, por tanto, constituye un bien intangible del dominio público, que cumple con una doble función: por un lado, representa un factor de bienestar individual y social y, por el otro, es un recurso económico para la ciudad mediante la concesión de su uso o aprovechamiento. De ahí que uno de los objetivos de la citada ley sea evitar la proliferación de una publicidad exterior desordenada y una saturación del paisaje urbano, pues ello se traduce en contaminación visual que afecta la calidad de vida de los habitantes del Distrito Federal y les impide disfrutar de un entorno armónico».

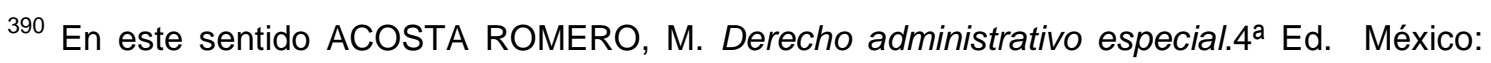
Porrúa, 2001, P. 149 y 211. Establece que el Patrimonio del Estado «Es el conjunto de elementos materiales e inmateriales tanto del dominio público, como del privado, cuya titularidad es del Estado, ya sea de forma directa o indirecta (a través de organismos descentralizados o sociedades mercantiles de Estado), y que le sirven para el cumplimiento de 
intangibles de interés público, inherentes a su estructura política y social, con características diversas (espacio radioeléctrico ${ }^{391}$, derechos de autor, etc. ${ }^{392}$ ),

su actividad y cometido»; por lo que cuando se refiere al listado de bienes que contempla el artículo 27 Constitucional, se pronuncia diciendo que "Como hemos visto, el patrimonio del Estado es un concepto que abarca una serie de bienes que difícilmente se encasillaría en esta clasificación». DELGADILLO GUTIÉRREZ, L.H. y LUCERO ESPINOSA, M. Elementos de derecho administrativo segundo curso. 1르. Ed. México: Limusa, 2002, p. 54 «En consecuencia, es posible conceptualizar el patrimonio del Estado como el conjunto de bienes materiales 0 incorpóreos, susceptibles de apreciación pecuniaria o no, y de obligaciones del mismo, que posee como elementos constitutivos de su estructura político social y que los destina de manera directa o indirecta a la consecución de sus objetivos. SERRA ROJAS,A. Derecho administrativo, segundo curso. 25 Ed. México: Porrúa, 2008, p. 247 «El patrimonio del Estado se halla constituido por la universalidad de los derechos y acciones de que es titular, los cuales pueden valorarse pecuniariamente, sumados a las obligaciones y derechos".

${ }^{391}$ Época: Décima Época. Registro: 2005184. Instancia: Tribunales Colegiados de Circuito. Tipo de Tesis: Aislada. Fuente: Gaceta del Semanario Judicial de la Federación Libro 1, Diciembre de 2013, Tomo II. Materia(s): Administrativa. Tesis: I.4o.A.72 A (10a.) Página: 1129. Rubro: ESPECTRO RADIOELÉCTRICO. SU CONCEPTO Y DISTINCIÓN CON RESPECTO AL ESPECTRO ELECTROMAGNÉTICO. Texto: «El artículo 3, fracción Il, de la Ley Federal de Telecomunicaciones define al espectro radioeléctrico como el espacio que permite la propagación, sin guía artificial de ondas electromagnéticas, cuyas bandas de frecuencia se fijan convencionalmente por debajo de los tres mil gigahertz. Así, las frecuencias se agrupan convencionalmente en bandas, de acuerdo a sus características, y el conjunto de éstas constituye el espectro radioeléctrico, el cual integra una parte del espectro electromagnético utilizado como medio de transmisión para distintos servicios de telecomunicaciones, y es un bien del dominio público respecto del cual no debe haber barreras ni exclusividad que impidan su funcionalidad y el beneficio colectivo. Cabe señalar que el espectro radioeléctrico es un recurso natural limitado y las frecuencias que lo componen son las que están en el rango entre los tres hertz y los tres mil gigahertz $y$, en esa virtud, su explotación se realiza aprovechándolas directamente o concediendo el aprovechamiento mediante la asignación a través de concesiones».

392 MARTÍNEZ MORALES, R. Derecho administrativo 3er. Y 4º Cursos. 4ª ED. México: Oxford, 2005, P.20 y 23 «Patrimonio del Estado. Concepto. (...) universalidad de bienes, derechos y recursos financieros con que cuenta el Estado para cumplir sus atribuciones.(...) Entendidos los derechos con un contenido económico, distintos de los bienes y recursos financieros, el estado es titular de una larga serie de ellos: servidumbres, patentes de invención, marcas, 
sobre los que el Estado ejerce directa o indirectamente poderes de dominio en forma de posesión, administración y/o regulación.

¿Encuadra la economía y el circuito económico en particular en estos criterios?

El artículo 25 de la CPEUM ${ }^{393}$ confiere la rectoría del Estado sobre la actividad económica nacional en pro del desarrollo económico y social, otorgando con

derechos de autor, participación en sociedades y asociaciones, derechos sucesorios, entre otros».

${ }^{393}$ Artículo 25. "Corresponde al Estado la rectoría del desarrollo nacional para garantizar que éste sea integral y sustentable, que fortalezca la Soberanía de la Nación y su régimen democrático y que, mediante la competitividad, el fomento del crecimiento económico y el empleo y una más justa distribución del ingreso y la riqueza, permita el pleno ejercicio de la libertad y la dignidad de los individuos, grupos y clases sociales, cuya seguridad protege esta Constitución. La competitividad se entenderá como el conjunto de condiciones necesarias para generar un mayor crecimiento económico, promoviendo la inversión y la generación de empleo. Párrafo reformado DOF 28-06-1999, 05-06-2013

El Estado planeará, conducirá, coordinará y orientará la actividad económica nacional, y llevará al cabo la regulación y fomento de las actividades que demande el interés general en el marco de libertades que otorga esta Constitución.

Al desarrollo económico nacional concurrirán, con responsabilidad social, el sector público, el sector social y el sector privado, sin menoscabo de otras formas de actividad económica que contribuyan al desarrollo de la Nación.

El sector público tendrá a su cargo, de manera exclusiva, las áreas estratégicas que se señalan en el artículo 28, párrafo cuarto de la Constitución, manteniendo siempre el Gobierno Federal la propiedad y el control sobre los organismos y empresas productivas del Estado que en su caso se establezcan. Tratándose de la planeación y el control del sistema eléctrico nacional, y del servicio público de transmisión y distribución de energía eléctrica, así como de la exploración y extracción de petróleo y demás hidrocarburos, la Nación llevará a cabo dichas actividades en términos de lo dispuesto por los párrafos sexto y séptimo del artículo 27 de esta Constitución. En las actividades citadas la ley establecerá las normas relativas a la administración, organización, funcionamiento, procedimientos de contratación y demás actos jurídicos que celebren las empresas productivas del Estado, así como el régimen de remuneraciones de su 
ello una serie de derechos de administración, gestión, regulación, posesión y/o monopolio sobre sectores económicos estratégicos ${ }^{394}$.

personal, para garantizar su eficacia, eficiencia, honestidad, productividad, transparencia y rendición de cuentas, con base en las mejores prácticas, y determinará las demás actividades que podrán realizar. Párrafo reformado DOF 20-12-2013

Asimismo podrá participar por sí o con los sectores social y privado, de acuerdo con la ley, para impulsar y organizar las áreas prioritarias del desarrollo.

Bajo criterios de equidad social, productividad y sustentabilidad se apoyará e impulsará a las empresas de los sectores social y privado de la economía, sujetándolos a las modalidades que dicte el interés público y al uso, en beneficio general, de los recursos productivos, cuidando su conservación y el medio ambiente. Párrafo reformado DOF 20-12-2013

La ley establecerá los mecanismos que faciliten la organización y la expansión de la actividad económica del sector social: de los ejidos, organizaciones de trabajadores, cooperativas, comunidades, empresas que pertenezcan mayoritaria o exclusivamente a los trabajadores y, en general, de todas las formas de organización social para la producción, distribución y consumo de bienes y servicios socialmente necesarios.

La ley alentará y protegerá la actividad económica que realicen los particulares y proveerá las condiciones para que el desenvolvimiento del sector privado contribuya al desarrollo económico nacional, promoviendo la competitividad e implementando una política nacional para el desarrollo industrial sustentable que incluya vertientes sectoriales y regionales, en los términos que establece esta Constitución. Párrafo reformado DOF 05-06-2013, 20-12-2013. Artículo reformado DOF 03-02-1983"

${ }^{394}$ Época: Novena Época. Registro: 166883 . Instancia: Pleno. Tipo de Tesis: Jurisprudencia. Fuente: Semanario Judicial de la Federación y su Gaceta Tomo XXX, Julio de 2009. Materia(s): Constitucional. Tesis: P./J. 76/2009. Página: 1543. Rubro: PLANEACIÓN DEMOCRÁTICA DEL DESARROLLO NACIONAL Y SISTEMA NACIONAL DE DESARROLLO SOCIAL. SE FUNDAMENTAN EN LOS ARTÍCULOS 25 Y 26 DE LA CONSTITUCIÓN POLÍTICA DE LOS ESTADOS UNIDOS MEXICANOS. Texto: «Los citados preceptos establecen la rectoría económica del Estado para garantizar el crecimiento económico del país, la cual se cumple en los términos previstos en los propios dispositivos constitucionales, cuando el Estado alienta la producción, concede subsidios, otorga facilidades a empresas de nueva creación, estimula la exportación de sus productos, concede facilidades para la importación de materias primas, organiza el sistema de planeación democrática del desarrollo nacional y el sistema nacional de 
El Estado en el ejercicio de esa rectoría, interviene en la economía en dos formas distintas, como un Estado regulador y como Estado empresario. En la primera el Estado actúa «en ejercicio de su facultad constitucional de planificación de actividades económicas, sociales y culturales, para la realización de ciertos fines, que no podrían cumplirse si se dejaran al libre intercambio de las personas, a quienes, por tanto, no se les concibe como sujetos pasivos de una potestad coactiva, sino como sujetos participantes y activos de un cierto sector o mercado regulado ${ }^{395}$. En tanto en el segundo de

desarrollo social, entre otras acciones. En estos preceptos constitucionales se establece la responsabilidad del Estado de organizar y conducir el desarrollo nacional, mediante el establecimiento de un sistema de planeación democrática que sea sólido, dinámico, permanente $y$ equitativo al crecimiento de la economía para la independencia $y$ democratización política, social y cultural de la nación. De este modo, la planeación deberá llevarse a cabo como un medio para el eficaz desempeño de la responsabilidad del Estado sobre el desarrollo integral y sustentable del país y deberá atender a la consecución de los fines y objetivos políticos, sociales, culturales y económicos contenidos en la Constitución Política de los Estados Unidos Mexicanos. Por tanto, la planeación nacional de desarrollo es la ordenación racional y sistemática de acciones que, con base en el ejercicio de las atribuciones del Ejecutivo Federal en materia de regulación y promoción de la actividad económica, social, política, cultural, de protección al ambiente y aprovechamiento racional de los recursos naturales, tiene como propósito la transformación de la realidad del país, de conformidad con las normas, principios y objetivos que la propia Constitución y las diversas leyes que las desarrollan establecen».

${ }^{395}$ Época: Décima Época. Registro: 2007408. Instancia: Primera Sala. Tipo de Tesis: Aislada. Fuente: Gaceta del Semanario Judicial de la Federación Libro 10, septiembre de 2014, Tomo I. Materia(s): Constitucional. Tesis: 1a. CCCXVII/2014 (10a.). Página: 574. Rubro: ESTADO REGULADOR. PARÁMETRO CONSTITUCIONAL PARA DETERMINAR LA VALIDEZ DE SUS SANCIONES. Texto: «Existe un ámbito en donde el Estado vigila la desviación de la conducta prescrita jurídicamente no sólo en su calidad de Estado policía o vigilante, sino en su papel de Estado regulador, esto es, en ejercicio de su facultad constitucional de planificación de actividades económicas, sociales y culturales, para la realización de ciertos fines, que no podrían cumplirse si se dejaran al libre intercambio de las personas, a quienes, por tanto, no se les concibe como sujetos pasivos de una potestad coactiva, sino como sujetos participantes y 
los supuestos «el Estado ha tomado a su cargo la realización de actividades de interés público, las cuales podríamos agrupar en tres grandes rubros: las bancarias y financieras, las de productor de determinados bienes y las de distribuidor de artículos de primera necesidad y regulador del mercado, englobadas en el concepto general de servicios de interés público, conocidos también por la doctrina como servicios públicos virtuales o impropios» ${ }^{396}$.

activos de un cierto sector o mercado regulado. Así, esta nota planificadora o reguladora ha marcado el tránsito de un modelo de estado de derecho, en donde el Estado tenía una función subsidiaria y secundaria para intervenir en caso de una ruptura del orden público, al estado social de derecho, en donde el Estado tiene una función central de rectoría económica, cuyo fundamento se encuentra conjunta y principalmente en los artículos 25 y 28 de la Constitución Política de los Estados Unidos Mexicanos. Ahora bien, debe destacarse que las sanciones impuestas en este sector presuponen un contexto diferenciado, en el que los particulares se ubican como sujetos activos y participantes de ciertos mercados, o como prestadores de un servicio concesionado o permisionarios para la explotación de un bien público, por lo que su conducta está regulada por normas, que si bien tienen como marco una ley que establece las líneas regulativas principales, también se integra por una pluralidad de instrumentos normativos, como son reglamentos, normas oficiales mexicanas u otras de naturaleza administrativa, que son requeridas por la regulación especializada técnica y flexible para la realización de ciertos fines de políticas públicas, establecidos en la Constitución o en las leyes las que, en contrapartida, se han de desarrollar por órganos administrativos igualmente especializados y técnicos. De ahí que el modelo de Estado regulador supone un compromiso entre principios: el de legalidad, el cual requiere que la fuente legislativa, con legitimidad democrática, sea la sede de las decisiones públicas desde donde se realice la rectoría económica del Estado, y los principios de eficiencia y planificación que requieren que los órganos expertos y técnicos sean los que conduzcan esos principios de política pública a una realización óptima, mediante la emisión de normas operativas que no podrían haberse previsto por el legislador, o bien, estarían en un riesgo constante de quedar obsoletas, pues los cambios en los sectores tecnificados obligaría a una adaptación incesante poco propicia para el proceso legislativo y más apropiado para los procedimientos administrativos».

${ }^{396}$ FERNÁNDEZ RUÍZ, J. El Estado empresario. 1르 Ed. México: Instituto de Investigaciones Jurídicas UNAM, 1982, P. 221 
Visto lo anterior es fácil determinar que sea cual sea la participación del Estado (como regulador o como empresario), la economía en el Derecho mexicano se trata de una serie de bienes intangibles de interés público, inherentes a la estructura política y social de la Federación de conformidad con los artículos 25, 26 y 28 de la CPEUM, sobre los cuales ejerce directa e indirectamente poderes de dominio en forma de posesión, administración y regulación, que no permiten por su propia naturaleza se encuentren en posesión de particulares, pues eso ocasionaría un perjuicio a la generalidad de la sociedad ${ }^{397}$.

Por lo que una vez determinada la pertinencia de la declaratoria de la economía, y más específicamente del mercado, como un bien de dominio público, es preciso identificar cómo se da la utilización del bien de dominio público con la entrada de una mercancía extranjera a la economía nacional ${ }^{398}$.

\footnotetext{
397 Época: Novena Época. Registro: 191360. Instancia: Pleno. Tipo de Tesis: Aislada. Fuente: Semanario Judicial de la Federación y su Gaceta Tomo XII, Agosto de 2000. Materia(s): Constitucional. Tesis: P. CXIV/2000. Página: 149. Rubro: RECTORÍA ECONÓMICA DEL ESTADO EN EL DESARROLLO NACIONAL. LOS ARTÍCULOS 25 Y 28 CONSTITUCIONALES QUE ESTABLECEN LOS PRINCIPIOS RELATIVOS, NO OTORGAN DERECHOS A LOS GOBERNADOS, TUTELABLES A TRAVÉS DEL JUICIO DE AMPARO, PARA OBLIGAR A LAS AUTORIDADES A ADOPTAR DETERMINADAS MEDIDAS. Texto: "Los artículos 25 y 28 de la Carta Magna establecen, en esencia, la rectoría económica del Estado para garantizar el crecimiento económico del país, que se cumple, en los términos previstos en los propios preceptos constitucionales, mediante diversas acciones en que el Estado alienta la producción, concede subsidios, otorga facilidades a empresas de nueva creación, estimula la exportación de sus productos, concede facilidades para la importación de materias primas y prohíbe los monopolios, esto es, todo acto que evite o tienda a evitar la libre concurrencia en la producción industrial o comercial y, en general, todo lo que constituye una ventaja exclusiva e indebida en favor de una o varias personas, con perjuicio del pueblo en general o de una clase social;(...) ».

${ }^{398}$ Es de resaltar que en el Derecho Mexicano no se hace referencia al circuito económico, sino a la acepción más amplia de economía, diferencia terminológica que no afecta la esencia del
} 
El Estado crea condiciones propicias para el intercambio de bienes y servicios, que beneficien a todos y que procuren el desarrollo nacional, la propia actividad rectora del Estado tiene como fin el mantenimiento, equilibrio y funcionalidad de ese sistema de intercambios. Al ingresar una mercancía exógena a la economía nacional, ésta se sirve de esas condiciones, las cuales de no existir sería imposible que se llevaran a cabo los intercambios comerciales, por lo que al servirse de ellas se está haciendo uso de un bien de dominio público como es el circuito económico.

Permítaseme ahondar un poco más al respecto, utilizando los parámetros de medición de la capacidad contributiva, proporcionalidad y equidad de los derechos (tasas) por utilización de bienes de dominio público, que contempla la SCJN, la cual establece que: «Tratándose de derechos fiscales por el uso o aprovechamiento de bienes del dominio público de la Nación, a que se refieren los artículos 20., fracción IV, del Código Fiscal de la Federación y 10., párrafo primero, de la Ley Federal de Derechos, el principio tributario de proporcionalidad no puede apreciarse, como en los impuestos, tomando en cuenta la capacidad contributiva del obligado, pues las actividades de usar o aprovechar dichos bienes no reflejan por sí solas y de modo patente, disponibilidad económica; de ahí que el citado principio constitucional se haga derivar, partiendo del acto de permisión del Estado, del grado de 
aprovechamiento de los bienes del dominio público, medido en unidades de consumo o de utilización de acuerdo con la naturaleza del bien, así como del beneficio aproximado obtenido por el usuario y, en su caso, de la valoración de su mayor o menor disponibilidad o su reparación o reconstrucción, si se produce un deterioro. Por su parte, el principio de equidad tributaria de los derechos citados se cumple, por regla general, cuando las tasas aplicables son fijas e iguales para los gobernados que usan, explotan o aprovechan en similar grado el mismo bien de dominio público, al traducirse en un beneficio uniforme para ellos; o variables, si el grado de utilización del bien es diferente» 399 .

Vamos desmembrando esta jurisprudencia y encuadremos sus elementos con los de los derechos arancelarios. En primer lugar, establece como primer elemento determinador de capacidad contributiva y de proporcionalidad el grado de aprovechamiento medido en Unidades de consumo o de utilización de acuerdo con la naturaleza del bien. ¿Es posible que el mercado tenga distintos grados de aprovechamiento por una mercancía extranjera? La respuesta es simple, basta recurrir a la normativa aduanera para ver los distintos regímenes aduaneros, pues cada uno de ellos representan formas distintas de incorporación de la mercancía que impactan de forma diferente la economía, pues va desde una incorporación total al mercado, pasando por una

${ }^{399}$ Época: Novena Época. Registro: 165045. Instancia: Segunda Sala. Tipo de Tesis: Jurisprudencia. Fuente: Semanario Judicial de la Federación y su Gaceta Tomo XXXI, Marzo de 2010. Materia(s): Constitucional, Administrativa. Tesis: 2a./J. 27/2010. Página: 1031. Rubro: DERECHOS POR USO O APROVECHAMIENTO DE BIENES DEL DOMINIO PÚBLICO DE LA NACIÓN. ELEMENTOS PARA DETERMINAR SU PROPORCIONALIDAD Y EQUIDAD. 
incorporación parcial como lo es la importación temporal, o la no incorporación como lo es el tránsito aduanero.

Por otra parte, la jurisprudencia precisa que debe de considerarse dentro de ese grado de aprovechamiento «el beneficio aproximado obtenido por el usuario y, en su caso, de la valoración de su mayor o menor disponibilidad o su reparación o reconstrucción, si se produce un deterioro».

En cuanto al grado de beneficio, es evidente que quien importa lo hace porque la mercancía extranjera le representa un beneficio mayor, regularmente por un menor costo de la mercancía extranjera frente al producto nacional. En torno a la mayor o menor disposición del bien de dominio público, como vimos en el capítulo II, el mercado tiene múltiples acepciones, pero todas ellas siempre describen un bien limitado por su propia naturaleza (territorial, sectorial, productiva, etc.). Esa limitación propia del mercado hace que el acceso al circuito económico (intercambio de bienes y servicios) sea preferente para los productos que se generan internamente y que puedan competir entre sí en igualdad de términos y condiciones para sostener un equilibrio, pues cualquier desigualdad causaría un desequilibrio en el mercado que repercutiría en perjuicio de la colectividad, por lo que la entrada de una mercancía extranjera a este circuito económico puede causar un perjuicio al interior del mercado, ya sea por traer un precio más bajo que el producto nacional, o bien saturar el mercado y no dejar espacios para los productos nacionales. Cuando hay una sobre producción o escasea cierta materia prima, es necesario relacionarse con otros mercados a fin de compensar las necesidades del mercado y 
conseguir un equilibrio. Cuando el flujo es constante entre los mercados se mantiene un equilibrio, pero si el flujo es de distinta intensidad o en un solo sentido, se satura el mercado receptor y puede colapsar su economía; de igual forma la ausencia de cierta materia prima en el mercado interior puede ocasionar el mismo efecto devastador ${ }^{400}$.

${ }^{400}$ En sentido análogo de lo que estamos comentando encontramos la siguiente tesis. Época: Décima Época. Registro: 2002128. Instancia: Tribunales Colegiados de Circuito. Tipo de Tesis: Aislada. Fuente: Semanario Judicial de la Federación y su Gaceta Libro XIV, Noviembre de 2012, Tomo 3. Materia(s): Constitucional. Tesis: I.3o.C.51 C (10a.). Página: 1848. Rubro: CONSUMIDOR O USUARIO DE SERVICIOS FINANCIEROS. EL ACCESO AL MERCADO EN CONDICIONES DE LIBRE COMPETENCIA Y CONCURRENCIA, ES UN DERECHO HUMANO PROTEGIDO POR EL ARTÍCULO 28, PÁRRAFOS PRIMERO Y SEGUNDO, DE LA CONSTITUCIÓN POLÍTICA DE LOS ESTADOS UNIDOS MEXICANOS. Texto: “Una interpretación histórica y progresiva del artículo 28, párrafos primero y segundo, de la Constitución Federal, permite advertir que se parte del supuesto de que en el mercado, como espacio de intercambio mercantil, concurren numerosos propietarios o proveedores de mercancías o servicios frente a aquellos que necesitan esos bienes para satisfacer sus intereses, lo que evidencia que existen diferentes facetas de la libertad individual que se ven involucradas en el mecanismo del mercado, a saber, las que se refieren a libertades sustantivas, la autonomía decisional y la inmunidad frente a las intrusiones de factores que obliguen a elegir al consumidor de una manera y no de otra. La economía moderna configura al mercado como un espacio competitivo y la libertad de las personas en este ámbito tiene dos facetas: a) de oportunidad; $y$, b) de proceso de la libertad. La primera de ellas se refiere a la capacidad real de los individuos para conseguir cosas, en el que se centra la postura del consumidor y tiene un valor instrumental en la medida en que sólo puede elegir aquello que esté dentro de un "conjunto presupuestario", es decir, lo que realmente se puede conseguir dentro de lo que se ofrece; tiene una estrecha relación con el concepto de preferencias, esto es, la posibilidad de elección entre diversas opciones o alternativas cuya decisión se apoya en un conjunto de valores de los individuos y no únicamente en sus gustos. La segunda faceta hace referencia al procedimiento de decidir libremente por uno mismo, que implica la autonomía decisional de las elecciones a realizar, en tanto que una persona decide por sí misma y no otras por ella y la inmunidad frente a la interferencia de los demás. Entonces, el derecho a intervenir en el mercado para vender o adquirir mercancías libremente sin interferencia alguna debe realizarse sin que nadie se interponga, en condiciones de 
oportunidad y de libertad, que se justifica por los resultados o utilidades sociales que produce. Empero, los desequilibrios en el mercado existen ya sea que se aproveche una determinada ventaja comparativa o privilegio del productor por lo cual se establecen parámetros de su corrección o atenuación. Entre esos desequilibrios están el monopolio, el oligopolio y las situaciones inherentes que descansan en el tipo, cantidad y calidad de la mercancía ofertada, incluso la idea de protección al ambiente; la intromisión en la selección y decisión por el consumidor para adquirir una mercancía o en aspectos en los que no existe real competencia, por regularse a favor del Estado la producción del bien o la prestación del servicio en que el margen de libertad del consumidor se acota aún más, pues no sólo corresponde al precio que puede definirse en función de sus alcances presupuestarios, sino de lo que el Estado permite que pueda ofrecerse en términos de competencia tanto cuando la restringe en su favor, como cuando se trata de actividades estratégicas o de interés público, que afectan, además, la libre concurrencia. Una forma de garantizar que la relación entre los usuarios de los servicios financieros y las instituciones respectivas pueda garantizar condiciones de profesionalismo, equidad y legalidad, son las normas de derechos humanos que se encuentran contenidas en el artículo 28 constitucional y en los tratados internacionales suscritos por el Estado Mexicano. El artículo 28, párrafos primero y segundo, de la Constitución Federal que reconoce un derecho humano del consumidor que tiene diversas facetas, pues por un lado establece una prohibición de existencia de monopolios, prácticas monopólicas, estancos y exenciones de impuestos, así como las prohibiciones a título de protección a la industria, en los términos previstos por las leyes. Por esa razón, se dispone que la ley castigará severamente y que debe ser perseguido con eficacia por las autoridades, toda concentración o acaparamiento en una o pocas manos de artículos de consumo necesario y que tenga por objeto obtener el alza de los precios; todo acuerdo, procedimiento o combinación de los productores, industriales, comerciantes o empresarios de servicios, que de cualquier manera hagan, para evitar la libre concurrencia o la competencia entre sí y obligar a los consumidores a pagar precios exagerados $y$, en general, todo lo que constituya una ventaja exclusiva indebida a favor de una o varias personas determinadas y con perjuicio del público en general o de alguna clase social. Con esa prohibición, lo que se reconoce implícitamente es un derecho humano de la persona en su vertiente de consumidor frente al abuso de los productores, industriales, comerciantes o empresarios de servicios, que impidan la libre competencia y la libre concurrencia en el mercado que tenga como finalidad generar una ventaja en perjuicio de las demás personas, determinadas o indeterminadas. Es decir, el Constituyente parte del hecho de que existe una desigualdad en el mercado que es necesario atemperar y sobre todo que debe protegerse al consumidor como una parte débil de la relación económica ante la situación de escasez de bienes o servicios o de claro predominio de los proveedores de servicios o propietarios de bienes o mercancías, que implique una afectación a su patrimonio como producto de esa relación asimétrica o desigual’». 
Es palpable el costo que tiene el ingreso de la mercancía extranjera al mercado nacional ya sea por sus características o volumen, que impacta en una mayor ocupación del mercado o daño del mismo. Por lo que el parámetro de identificación de la capacidad contributiva se identificaría plenamente con lo señalado por la jurisprudencia, al igual que la proporcionalidad, pues si bien todas las mercancías utilizan el mismo bien denominado "mercado", el grado de utilización, es decir, el impacto del mercado es distinto dependiendo el tipo de mercancías y el destino de cada una de ellas. Por el contrario, como ya mencionábamos en párrafos anteriores, el artículo 61 de la Ley Aduanera establece el listado de exenciones a la imposición, cuyo elemento esencial consiste en que se trata de importaciones o exportaciones que no tienen repercusión en la economía por la naturaleza, destino, valor y/o cantidad de la mercancía sujeto de la operación, o lo que es lo mismo, a no ser sujetos de operaciones comerciales no utilizan el mercado.

Queda así plenamente probado, a mi juicio, que el supuesto genérico de importación en la legislación mexicana, al igual que en el caso europeo, se trata de derechos (tasas) por utilización de un bien de dominio público llamado mercado. 


\subsubsection{La importación definitiva. La naturaleza jurídico-tributaria de los derechos arancelarios por importación definitiva.}

El artículo 96 de la Ley Aduanera define la importación definitiva como «la entrada de mercancías de procedencia extranjera para permanecer en el territorio nacional por tiempo ilimitado», definición que me parece poco afortunada al centrar el elemento objetivo en la indefinición de la temporalidad, pues como veremos a lo largo de este epígrafe, no es un elemento determinante para conceder la definitividad.

Consideramos más adecuada la definición contenida por el artículo 8, fracción I, del abrogado Código Aduanero de los Estados Unidos Mexicanos, pues era más acorde a los estándares internacionales ${ }^{401}$ y tenía mucho más sentido su contenido al definir como importación definitiva «el arribo de mercancías extranjeras destinadas a su consumo o uso dentro del país", lo que concuerda con la postura ya comentada de CARVAJAL CONTRERAS de la integración económica de la mercancía ${ }^{402}$.

La jurisprudencia de la 5 $5^{\text {a }}$ Época recopilaba estas posturas de integración económica explicando de forma clara y concisa, el proceso de importación que, a decir de la Segunda Sala, iniciaba con la entrada de la mercancía al territorio

401 El acercamiento normativo aduanero de México con la normativa internacional fue el principal fundamento para abrogar el Código Aduanero de los Estados Unidos Mexicanos y crear la Ley aduanera.

402 CARVAJAL CONTRERAS, M. Derecho aduanero. Ob. Cit. p. 386 "Criterio económico, es cuando se da la intención integradora, es decir, en la importación, aquella que tiene como objetivo integrar la mercancía al consumo interno del país». 
y culminaba cuando la mercancía se encontraba a libre disposición del importador, otorgándoles en ese momento la categoría de mercancías nacionalizadas $^{403}$.

La actual construcción del artículo 96 parece alejarse de estas posturas y no tener mayor consideración para la imposición que la temporalidad de la permanencia de la mercancía en el territorio nacional, como sostiene RHODE $\mathrm{PONCE}^{404}$. Sin embargo, si hacemos una interpretación sistemática de la

${ }^{403}$ Época: Quinta Época. Registro: 316584. Instancia: Segunda Sala. Tipo de Tesis: Aislada. Fuente: Semanario Judicial de la Federación Tomo CXXVI. Materia(s): Administrativa. Página: 529. Rubro: IMPORTACIONES DEFINITIVAS EXENTAS. Texto: «En los términos del artículo 10 del Código Aduanero, toda importación territorial comienza al cruzar las mercancías la línea divisoria internacional y concluye cuando se ha terminado la tramitación fiscal respectiva y aquéllas quedan a la libre disposición de los interesados, entendiéndose por importación definitiva según el artículo 80. fracción l, el arribo de las mercancías extranjeras destinadas a su consumo o uso dentro del país, clasificándolas en estos casos, como mercancías nacionalizadas. Por tanto, si se han cumplido todos los requisitos legales del caso para que las importaciones de referencia deban considerarse definitivas en los términos de las disposiciones invocadas, y si en ellas se contiene la declaración de exención de impuestos, es indudable que en tal caso ha habido una decisión administrativa favorable a un particular que sólo puede nulificarse conforme al artículo 160, fracción VII, del Código Fiscal de la Federación mediante el juicio que promueva la Secretaría de Hacienda ante el Tribunal Fiscal de la Federación».

${ }^{404}$ RHODE PONCE, A. Derecho aduanero mexicano 2. Ob. Cit. P. 34 «El artículo 96 de la NLA es expreso en cuanto a la finalidad que persigue este régimen, es decir, que las mercancías se introduzcan al país para permanecer en él. En cuanto a los motivos particulares de la permanencia, la ley no hace ninguna distinción o limitación razón por lo cual las mercancías podrán ser destinadas a cualquier uso, disfrute o cometido, como la simple tenencia, el uso, la custodia o almacenamiento, la exhibición, transformación o reparación y en general, cualquier acto económico o jurídico, como la enajenación e incluso la destrucción física. Se podrá observar que la legislación abandonó la noción del "consumo" para calificar el motivo de la permanencia de las mercancías en el país, ya que ciertamente resulta muy limitado en relación con todos los actos o hechos, económicos o jurídicos, que sobre ellas se pueden ejecutar y que se citan, de manera ejemplificativa, en el párrafo anterior». 
norma veremos que no es así, pues como analizamos en el epígrafe anterior, no toda introducción de mercancías al territorio nacional hace que surja la obligación de pago del impuesto de importación, ni tampoco la temporalidad de su estadía en el territorio nacional, ya que el artículo 61 de la Ley aduanera establece un listado de mercancías que se encuentran exentas del pago de tributos al comercio exterior, teniendo el común denominador todas ellas que por su naturaleza, valor, cantidad o finalidad no son sujeto de comercio. A contrario sensu, y atendiendo a la misma interpretación sistemática y funcional de la norma ${ }^{405}$, deberá de entenderse que una mercancía será objeto de gravamen cuando por su naturaleza, valor, cantidad o finalidad sea sujeto de comercio.

\footnotetext{
${ }^{405}$ Época: Novena Época. Registro: 165006. Instancia: Tribunales Colegiados de Circuito. Tipo de Tesis: Aislada. Fuente: Semanario Judicial de la Federación y su Gaceta Tomo XXXI, Marzo de 2010. Materia(s): Administrativa. Tesis: I.40.A.703 A. Página: 3001. Rubro: INTERPRETACIÓN DE NORMAS TRIBUTARIAS. DEBE ATENDERSE INCLUSO A LA NATURALEZA ECONÓMICA DE LOS FENÓMENOS CONTEMPLADOS POR AQUÉLLAS, MÁS ALLÁ DE EXPRESIONES LITERALES O ENUNCIADOS FORMALES, NO SÓLO AL ESTABLECER CUÁLES SON LOS SUPUESTOS GRAVADOS, SINO TAMBIÉN AL FIJAR LÍMITES EXCEPCIONALES AL HECHO IMPONIBLE. Texto: «Es un principio general de derecho, de aplicación a la materia tributaria, que la intención, principios, sustancia o realidad gravada, sean tomados en cuenta para calificar los hechos al tenor de la normativa pertinente especialmente por su naturaleza y contenido económico-, más allá de expresiones literales o enunciados formales. En ese sentido, la Segunda Sala de la Suprema Corte de Justicia de la Nación en la tesis publicada en el Semanario Judicial de la Federación, Séptima Época, Volumen 82, Tercera Parte, página 31, cuyo rubro es: "LEYES FISCALES QUE IMPONEN CARGAS A LOS PARTICULARES, INTERPRETACIÓN DE.", recomendó atender, incluso, a la naturaleza económica de los fenómenos contemplados por dichas normas, al establecer que el intérprete debe buscar un equilibrio entre los intereses de los particulares y los del Estado. Así, dichos argumentos son aplicables no sólo al establecer cuáles son los supuestos gravados sino también $y$, por razones de equidad, cuando se fijen límites excepcionales al hecho imponible (deducciones)».
} 
En apoyo a lo anterior encontramos lo dispuesto por el artículo 63 de la Ley Aduanera $^{406}$, que determina la imposibilidad de enajenar, cambiar de uso y/o destino las mercancías que ingresaron al territorio bajo alguna franquicia, exención (total o parcial) y/o estímulo fiscal, pues de lo contrario serán sujetas a imposición como una importación normal. Deberá entenderse así que el cambio de uso o destino de la mercancía significa que éstas abandonan su estatus fuera del circuito económico y se incorporan a la economía del país, con lo que se clarifica que no es la "temporalidad" el elemento objetivo del tributo aduanero en México, sino la incorporación de la mercancía a la economía nacional.

Así lo han entendido CARVAJAL, RíOS, WITKER y PEREZ NIETO quienes, como nosotros, concuerdan que el hecho generador de la importación definitiva no puede consistir en la temporalidad de la permanencia de la mercancía en el territorio nacional, sino en el libre uso y consumo de la mercancía en el territorio nacional ${ }^{407}$, o lo que es lo mismo su integración total al circuito

\footnotetext{
${ }^{406}$ ARTICULO 63. Las mercancías importadas al amparo de alguna franquicia, exención o estímulo fiscal no podrán ser enajenadas ni destinadas a propósitos distintos de los que motivaron el beneficio. Su enajenación únicamente procederá cuando no se desvirtúen dichos propósitos. Cuando proceda la enajenación de las mercancías el adquirente quedará subrogado en las obligaciones del importador. Las autoridades aduaneras procederán al cobro del impuesto general de importación y de las cuotas compensatorias causados desde la fecha en que las mercancías fueron introducidas al territorio nacional, actualizándose el citado impuesto conforme al artículo 17-A del Código Fiscal de la Federación, cuando sean enajenadas o destinadas a finalidades diversas de las que motivaron el beneficio a que se refiere este artículo, independientemente de la imposición de las sanciones que correspondan.

407 En este mismo sentido CARVAJAL CONTRERAS, M. Derecho aduanero. Ob. Cit. p.438, dice: «... existen diferencias entre nuestra ley y la de los organismos internacionales. Para Bruselas y la Asociación (Se refiere a las definiciones otorgadas por los glosarios de términos
} 
económico, lo que no se da hasta que se cumplan la totalidad de formalidades a las que esté sujeta la importación, al igual que en el despacho a libre practica en la Unión Europea. Por lo que, al quedar claro que el hecho imponible de la importación definitiva en México es la incorporación de las mercancías al circuito económico, pasamos a discutir su naturaleza jurídico-tributaria.

del Consejo de Cooperación aduanera de Bruselas y al Latinoamericano), la importación es el hecho material de introducir mercancías a un territorio aduanero; para nosotros es algo más, es la "permanencia por tiempo ilimitado", es decir, el acto de nacionalización de las mercancías y su introducción a la libre circulación de los bienes, para ser usados o consumidos en el territorio nacional». RÍOS, G. y GARCÍA, T. "Diferencias entre impuestos aduaneros de importación y cuotas compensatorias del comercio exterior mexicano, en el ámbito del Derecho tributario. Reflexiones sobre la constitucionalidad de las últimas". Revista Jurídica Boletín mexicano de Derecho comparado [En línea]. Enero- abril 1998 [consulta 10/04/2015]. Disponible en internet: http://biblio.juridicas.unam.mx/revista/DerechoComparado/numero/91/art/art9.htm P.5 «En el caso de los impuestos de importación, el hecho imponible es la entrada legal de la mercancía al país o su importación. Pero, en términos legales, ¿Qué significa importación? Según la doctrina jurídica, este concepto va más allá de la entrada física de bienes al territorio sometido a gravamen, es decir, comprende dos momentos: 1) la admisión de la entrada por parte de la administración competente, y 2) la vocación de la incorporación permanente de los bienes al mercado interior, esto es, su destino a los procesos productivos o al consumo. Es importante destacar que la importación requieres el animus de incorpora definitivamente las mercancías al mercado interior; en consecuencia, si no existiese dicho animus no se provoca la importación, aunque las mercancías estén físicamente en espacio aduanero». WITKER, J. y PEREZ NIETO, L. Aspectos jurídicos del Comercio Exterior en México, $2^{2}$ Ed. México: Editorial Nueva Imagen, 1980, P. 147 «La importación es una operación por la que un producto de procedencia extranjera se dedica al consumo interior del territorio aduanero, previo el pago de los derechos de aduanas y de su importe en divisas extranjeras o en divisas nacionales transferibles. De esta definición se desprenden dos elementos esenciales de toda importación: a) introducir productos o mercancías del exterior, y b) destinación al consumo interno. La destinación al consumo es un sistema aduanero que aplica a las mercancías extranjeras antes de ser comercializadas en un mercado determinado, para lo cual es requisito indispensable el pago de los derechos de aduana. Por tanto incluye como condición esencial el pago de los derechos de aduana y el cumplimiento de las formalidades a e que está subordinada dicha operación". 
Con relación a la naturaleza jurídico-tributaria de los derechos arancelarios por importación definitiva cabe señalar con carácter previo que, tal como vimos en el epígrafe relativo al hecho imponible genérico, en México existe prácticamente una indefinición legal del impuesto, teniendo que recurrir a la jurisprudencia para identificar los elementos torales del impuesto en el sistema jurídico mexicano: ser una prestación de ley obligatoria, que se genera a consecuencia de una situación o movimiento de riqueza ${ }^{408}$, y la ausencia de contraprestación.

En un apartado anterior abordamos el tema desde la perspectiva del hecho imponible genérico y concluimos que no era factible ubicar las contribuciones a la importación dentro del género impuesto, en tanto no cumplía con esos tres requisitos básicos. Toca en suerte verlos ahora desde la perspectiva específica del régimen de la importación definitiva.

La incorporación de una mercancía al circuito económico, no implica forzosamente una situación o movimiento de riqueza que demuestre por si sola la potencialidad real del importador de hacerle frente a la prestación pecuniaria requerida por el Estado como consecuencia de la incorporación de la mercancía al territorio aduanero. Además, el cobro no se hace en proporción a esa presunta riqueza mostrada, pues si bien es cierto en la más de las veces

${ }^{408 E ́ p o c a: ~ N o v e n a ~ E ́ p o c a . ~ R e g i s t r o: ~ 192849 . ~ I n s t a n c i a: ~ P l e n o . ~ T i p o ~ d e ~ T e s i s: ~ J u r i s p r u d e n c i a . ~}$ Fuente: Semanario Judicial de la Federación y su Gaceta, Tomo X, Noviembre de 1999. Materia(s): Constitucional, Administrativa. Tesis: P./J. 109/99. Página: 22. RUBRO: CAPACIDAD CONTRIBUTIVA. CONSISTE EN LA POTENCIALIDAD REAL DE CONTRIBUIR A LOS GASTOS PÚBLICOS. OB. Cit. 
que los tributos aduaneros son ad-valorem, también lo es que el tipo aplicable no se fija en proporción a esa presunta riqueza mostrada, pues estos dependerán de las características y origen de la mercancía y no de su valor, incumpliendo con los principios constitucionales tributarios de capacidad contributiva y proporcionalidad que consagra el artículo 31 fracción IV de la Constitución, descritos y ejemplificados en la multicitada jurisprudencia de la SCJN 9ạ Época, Rubro: "CAPACIDAD CONTRIBUTIVA. CONSISTE EN LA POTENCIALIDAD REAL DE CONTRIBUIR A LOS GASTOS PÚBLICOS”.

Al igual que en el supuesto genérico, es evidente que la importación definitiva no cumple con la mayor parte de los requisitos previstos para ser considerada un impuesto, mucho menos de una "contribución de mejora" o de una "contribución de seguridad social" de los cuales no tiene ninguno de los elementos, por lo que solo resta encuadrarle en el género de los derechos (tasas) ${ }^{409}$, en el que al igual que en el supuesto genérico, cumple la totalidad de los elementos como veremos en los siguientes párrafos.

¿Cómo se da el aprovechamiento del circuito económico por una mercancía que se importa definitivamente?

Como ya hemos comentado en variadas ocasiones a lo largo de esta investigación, el aprovechamiento del bien de dominio público denominado mercado se da con la introducción de una mercancía extranjera al circuito

\footnotetext{
409 Recordemos que conforme al artículo $2^{\circ}$ del Código fiscal de la Federación «Las contribuciones se clasifican en impuestos, aportaciones de seguridad social, contribuciones de mejoras y derechos».
} 
económico que se desarrolla dentro de ese mercado. Es decir, el pago del tributo aduanero otorga el derecho de que una mercancía extranjera adquiera el carácter de nacional y pueda ser sujeto de comercio o consumo dentro de este circuito económico como cualquier otra mercancía nacional, con lo que el pago del tributo aduanero equivale al pago de cualquier acto de permisión del Estado para utilizar un bien de dominio público, siendo evidente que el presupuesto de hecho es acorde a lo establecido por el artículo 2 del CFF para los derechos (tasas).

El elemento temporal también nos lleva a considerarlo dentro de los derechos, pues mientras en el impuesto no puede nacer la obligación tributaria hasta que no se realice el hecho imponible, en el caso de los derechos el pago es anterior al nacimiento del hecho imponible al producirse de forma previa al acto de uso, goce, explotación o aprovechamiento del bien de dominio público ${ }^{410}$.

\footnotetext{
${ }_{410}$ Ley Federal de Derechos. Artículo 3, párrafo 2 «El pago de los derechos que establece esta Ley deberá hacerse por el contribuyente previamente a la prestación de los servicios o previo al uso, goce, explotación o aprovechamiento de bienes de dominio público de la Federación, salvo los casos en que expresamente se señale que sea posterior. Cuando no se compruebe que el pago de derechos se ha efectuado previamente a la prestación del servicio o del uso, goce o aprovechamiento de bienes de dominio público de la Federación y se trate de derechos que deban pagarse por anticipado, el servicio, uso, goce o aprovechamiento de bienes de dominio público de la Federación no se proporcionará». DE LA GARZA, S.F. Derecho Financiero Mexicano. Ob. Cit. P. 550 "Creemos que el sistema no presenta problemas en lo que se refiere a los créditos fiscales que tienen la naturaleza de impuestos. Éstos nacen en el momento mismo en que se realiza el hecho jurídico previsto por la ley como su presupuesto, que en el caso de los impuestos es siempre un acto de un particular.(...) En nuestra opinión, los derechos se causan o nacen en el momento en que efectivamente se presta el servicio administrativo, que viene a ser la situación que el Código Fiscal o la Ley de Hacienda señalan como hecho generador del crédito fiscal. En los casos en que la ley o la costumbre exigen que se haga el pago con prelación a la prestación del servicio, tal entrega debe considerarse como
} 
En la importación opera el segundo de los supuestos, el artículo 83 de la Ley Aduanera, cuyo tenor dicta que «Las contribuciones se pagarán por los importadores y exportadores al presentar el pedimento para su trámite en las oficinas autorizadas, antes de que se active el mecanismo de selección automatizado», es decir, en el momento de la presentación de la declaración en aduana ${ }^{411}$. Un acto que es previo a la liberación de la mercancía, esto es, antes de que se realice el hecho imponible que es la incorporación al circuito económico pues, como hemos visto, antes de ese momento no existe obligación de pago alguna por concepto de importación.

En los elementos cualitativos del tributo aduanero es donde se manifiesta con mayor claridad que estamos en presencia de un derecho y no de un impuesto. El artículo 64 de la Ley Aduanera dice: «La base gravable del impuesto general de importación es el valor en aduana de las mercancías, salvo los casos en que la ley de la materia establezca otra base gravable». A primera vista parecería que al ser ad-valorem sería proporcional con la riqueza manifestada,

una garantía que el Fisco exige a su favor, de tal manera que, si posteriormente no negase a producirse la prestación del servicio habría lugar a la repetición del pago hecho, por falta de causa jurídica generadora de la prestación fiscal. Puede decirse, que cuando el Fisco exige el pago anticipado del servicio, actúa como muchos empresarios privados, para no correr el riesgo de incurrir en un costo que no va a ser retribuido por el interesado".

411 Ley Aduanera. "Artículo 2. Para los efectos de esta Ley se considera: (...) «XVI. Pedimento, la declaración en documento electrónico, generada y transmitida respecto del cumplimiento de los ordenamientos que gravan y regulan la entrada o salida de mercancías del territorio nacional, en la que se contiene la información relativa a las mercancías, el tráfico y régimen aduanero al que se destinan, y los demás datos exigidos para cumplir con las formalidades de su entrada o salida del territorio nacional, así como la exigida conforme a las disposiciones aplicables». 
ya que el importador sería gravado en relación con el costo de la mercancía importada. Sin embargo, la determinación del crédito fiscal (cuota tributaria) ${ }^{412}$ se hace aplicando a la base gravable la cuota (tipo) que corresponda conforme a la clasificación arancelaria de las mercancías de acuerdo con lo establecido en el artículo 80 de la Ley Aduanera.

Es precisamente en la determinación del tipo aplicable donde existe el rompimiento de la proporcionalidad desde la perspectiva impositiva y la justificación para su consideración como derechos: la determinación del tipo no toma en cuenta parámetro alguno de capacidad contributiva, proporcionalidad y/o progresividad en relación al costo de la mercancía, sino del origen, tipo y destino de mercancía.

Cabe preguntarse bajo qué justificación impositiva podríamos gravar de forma diferente dos artículos importados del mismo origen y del mismo valor, pero de diferentes características. O bien gravar de forma mayor un artículo de menor valor, del mismo origen pero de diferentes características. O los mismos ejemplos anteriores pero ahora variando el origen de las mercancías. Son evidentes las múltiples variantes que se dan de violaciones a los principios de capacidad contributiva, igualdad, proporcionalidad y progresividad si quisiéramos sostenerlos desde la perspectiva impositiva.

\footnotetext{
${ }^{412}$ C.F.F. «Artículo 40.- Son créditos fiscales los que tenga derecho a percibir el Estado o sus organismos descentralizados que provengan de contribuciones, de sus accesorios o de aprovechamientos, incluyendo los que deriven de responsabilidades que el Estado tenga derecho a exigir de sus funcionarios o empleados o de los particulares, así como aquellos a los que las leyes les den ese carácter y el Estado tenga derecho a percibir por cuenta ajena".
} 
La cuantificación del hecho imponible no puede realizarse desde la perspectiva impositiva porque, como hemos visto, en la incorporación de una mercancía al circuito económico no es posible medir la manifestación de riqueza bajo los parámetros impositivos, pues no se presenta de manera clara.

No así desde la perspectiva de los Derechos. La SCJN en su ya citada jurisprudencia de la 9a Época, Rubro: DERECHOS POR USO O APROVECHAMIENTO DE BIENES DEL DOMINIO PÚBLICO DE LA NACIÓN. ELEMENTOS PARA DETERMINAR SU PROPORCIONALIDAD Y EQUIDAD, dice: «Tratándose de derechos fiscales por el uso o aprovechamiento de bienes del dominio público de la Nación, a que se refieren los artículos 20., fracción IV, del Código Fiscal de la Federación y 10., párrafo primero, de la Ley Federal de Derechos, el principio tributario de proporcionalidad no puede apreciarse, como en los impuestos, tomando en cuenta la capacidad contributiva del obligado, pues las actividades de usar o aprovechar dichos bienes no reflejan por sí solas y de modo patente, disponibilidad económica; de ahí que el citado principio constitucional se haga derivar, partiendo del acto de permisión del Estado, del grado de aprovechamiento de los bienes del dominio público, medido en unidades de consumo o de utilización de acuerdo con la naturaleza del bien, así como del beneficio aproximado obtenido por el usuario $y$, en su caso, de la valoración de su mayor o menor disponibilidad o su reparación o reconstrucción, si se produce un deterioro. Por su parte, el principio de equidad tributaria de los derechos citados se cumple, por regla general, cuando las tasas aplicables son fijas e iguales para los gobernados que usan, explotan o aprovechan en similar grado el mismo bien de dominio 
público, al traducirse en un beneficio uniforme para ellos; o variables, si el grado de utilización del bien es diferente" ${ }^{313}$.

De esta jurisprudencia desprendemos los siguientes conceptos básicos a cumplir por un derecho por utilización de un bien de dominio público:

1. Acto de permisión del Estado. Como vimos en párrafos anteriores y siguiendo a CARVAJAL CONTRERAS ${ }^{414}$, se estableció que la relación aduanera otorga al importador el derecho a introducir definitivamente las mercancías para ser utilizadas o consumidas en el territorio aduanero. Derecho que se adquiere por el pago del tributo, que tiene como consecuencia la autorización del Estado para que se introduzca la mercancía al territorio aduanero.

2. Grado de aprovechamiento y valoración de su mayor o menor disponibilidad. Como ya explicamos en otros apartados, el mercado es un bien finito limitado por su propia naturaleza tanto física como de unidades posibles de desplazamiento de la mercancía en el mercado. Así pues, una mercancía determinada puede cubrir una mayor o menor cuota del mercado interno, por lo cual se fijan las cuotas arancelarias

\footnotetext{
${ }^{413}$ Época: Novena Época. Registro: 165045. Instancia: Segunda Sala. Tipo de Tesis: Jurisprudencia. Fuente: Semanario Judicial de la Federación y su Gaceta Tomo XXXI, Marzo de 2010. Materia(s): Constitucional, Administrativa. Tesis: 2a./J. 27/2010. Página: 103. Rubro: DERECHOS POR USO O APROVECHAMIENTO DE BIENES DEL DOMINIO PÚBLICO DE LA NACIÓN. ELEMENTOS PARA DETERMINAR SU PROPORCIONALIDAD Y EQUIDAD.

${ }^{414}$ Ver al respecto CARVAJAL CONTRERAS, M. Derecho aduanero. Ob. Cit. p.71
} 
que determinan la cantidad de mercancía que puede ingresar del exterior de acorde a las necesidades propias del mercado, dependiendo en gran medida el grado de aprovechamiento de las necesidades de la mercancía en el circuito económico. Si la cuota arancelaria es limitada, cualquier mercancía que ingrese tendrá un mayor aprovechamiento del circuito económico, frente aquellas que son de cuotas amplias. Verbigracia: en una sociedad cuya base de alimentación es el maíz y es deficitaria en su producción interna, es evidente que necesitarán para el correcto funcionamiento del circuito económico el ingreso del maíz necesario para cubrir sus necesidades de consumo; así pues, la cuota arancelaria será mucho mayor, por lo que el grado de aprovechamiento será menor. En cambio, ese mismo Estado produce calzado de manera suficiente para abastecer su mercado interno y para exportar, por lo que las cuotas arancelarias son menores, de manera que cualquier calzado extranjero que se importe cubrirá proporcionalmente una parte mayor de la cuota arancelaria, es decir, tendrá un mayor aprovechamiento del bien de dominio público que es el mercado. De igual forma, el origen de la mercancía puede ampliar o disminuir esas cuotas de mercado en proporción al flujo económico que exista entre el Estado de origen y destino. Cuando existen relaciones de intercambio económico preferencial entre los estados, es obvio que se amplía el flujo del mercado y con ello los cupos. En contrapartida, la ausencia de relaciones comerciales no tienen ampliación de flujo alguno ni de cupos. 
3. Valoración de su reparación o reconstrucción, si se produce un deterioro. El mercado puede ser sujeto de deterioro por todas aquellas cosas que afecten su buen funcionamiento, ya sea escasez de determinado producto, la sobreproducción, la competencia entre productos que cumplan el mismo fin, etc. Como vimos en el párrafo anterior una mercancía determinada puede ocasionar mayor o menor trastorno en el circuito económico de acorde a las necesidades de la mercancía y su disponibilidad dentro del mercado, por lo que el costo que tiene para un Estado recibir mercancías que desplazan en proporción mayor a las mercancías internas tendrá una repercusión mayor para el Estado el reparar las desigualdades que se generen a consecuencia de ello. Por el contrario, el Estado no tendrá costo alguno al permitir la entrada de mercancías de producción deficitaria, que no se producen en el territorio y de primera necesidad de su mercado, ya que la ausencia de las mercancías en el mercado crearían un coste mayor al Estado para estabilizar la economía, lo que justifica el cobro diferenciado de acorde al tipo y origen de la mercancía conforme al costo que tiene para el Estado la recepción de la mercancía.

Visto lo anterior, es innegable que nos encontramos ante un derecho por utilización de un bien de dominio público que, en su tarifa diferenciada dependiendo del tipo de mercancía y el origen de la misma, cumple los principios de capacidad contributiva, requeridos por nuestra Constitución. 


\subsubsection{La importación temporal.}

La Sección primera del Capítulo 4 de la Ley Aduanera regula la importación temporal (artículos 104 al 112), agrupando este régimen en dos supuestos:

1. Para retornar al extranjero en el mismo Estado.

2. Para elaboración, transformación o reparación en programas de maquila o de exportación.

Si bien la ley no otorga en sus disposiciones generales una definición que integre ambos supuestos, de la definición específica que hace en el artículo 106 podemos decir que «Se entiende por régimen de importación temporal, la entrada al país de mercancías para permanecer en él por tiempo limitado y con una finalidad específica».

La Ley Aduanera establece como presupuestos en común de la importación temporal, la exención del pago de impuestos al comercio exterior (salvo en los casos previstos en los artículos 63-A, 105, 108, fracción III, 110 y 112) ${ }^{415}$; además dicta restricciones de dominio sobre las mercancías, las cuales no podrán ser objeto de transferencia o enajenación, salvo entre maquiladoras o empresas con programas de exportación autorizadas en cuyo caso no aplicaría

\footnotetext{
${ }^{415}$ Ley Aduanera. "ARTICULO 104. Las importaciones temporales de mercancías de procedencia extranjera se sujetarán a lo siguiente: $I$. No se pagarán los impuestos al comercio exterior ni las cuotas compensatorias. Lo dispuesto en esta fracción no será aplicable en los casos previstos en los artículos 63- A, 105, 108, fracción III, 110 y 112 de esta Ley. II. Se cumplirán las demás obligaciones en materia de regulaciones y restricciones no arancelarias».
} 
la exención tributaria ${ }^{416}$. Es decir, que bajo este régimen general las mercancías ingresan al territorio aduanero por un lapso y fin determinado al margen del circuito económico, razón por la cual se encuentran exentas del pago de tributos. Sin embargo, cuando las mercancías son objeto de transferencia o enajenación ingresan al circuito económico y por lo tanto nace la obligación tributaria, como veremos detenidamente en los párrafos subsecuentes.

La temporalidad de la estancia está marcada por los artículos 106 y 108 de la Ley aduanera que conforme al tipo de mercancía y finalidad de importación determina el plazo que éstas podrán permanecer en el territorio.

En el supuesto de la importación temporal, la especifidad en el fin de la importación es un elemento determinante del hecho imponible; el ya transcrito artículo 106 de la Ley Aduanera establece que debe de entenderse por importación temporal la entrada al país de mercancías para permanecer en él por tiempo limitado y con una finalidad específica.

En palabras de RHODE PONCE, «La finalidad específica no constituye un uso legalmente determinado, sino que quiere decir que la entrada al país tiene un objetivo, fijado libremente por el importador, que no es necesario exponer $y$

\footnotetext{
${ }^{416}$ Artículo 105 Ley Aduanera «La propiedad o el uso de las mercancías destinadas al régimen de importación temporal no podrá ser objeto de transferencia o enajenación, excepto entre maquiladoras, empresas con programas de exportación autorizados por la Secretaría de Economía y empresas de comercio exterior que cuenten con registro de esta misma dependencia, cuando cumplan con las condiciones que establezca el Reglamento»
} 
comprobar a la autoridad aduanera, pero que busca que la mercancía no entre a la libre circulación de manera permanente ${ }^{417}$.

Una postura con la que concuerdo parcialmente, pues en casi todos los casos es necesario demostrar y garantizar a la autoridad aduanera la finalidad de la importación conforme lo establece el artículo 107 de la Ley aduanera ${ }^{418}$, prueba de ello es que la fracción VIII del artículo 105 del Código fiscal, considera como delito de contrabando equiparado al que «transforme las mercancías que debieron conservar en el mismo estado para fines distintos a los autorizados en los programas de maquila o exportación que se le hubiera otorgado; o destine las mercancías objeto de los programas de maquila o exportación a un fin distinto al régimen bajo el cual se llevó a cabo su importación».

\footnotetext{
${ }^{417}$ RHODE PONCE, A. Derecho aduanero mexicano 2. Ob cit. P. 103

${ }^{418}$ Ley Aduanera «ARTICULO 107. Tratándose de las importaciones temporales a que se refieren los incisos a), b) y d) de la fracción II, la fracción III, el inciso b) de la fracción IV y los incisos a), b), c) y e) de la fracción $V$ del artículo 106 de esta Ley, en el pedimento se señalará la finalidad a la que se destinarán las mercancías y, en su caso, el lugar en donde cumplirán la citada finalidad y mantendrán las propias mercancías. Quienes importen las mercancías a que se refieren los incisos a), c) y e) de la fracción $V$ del artículo 106 mencionado, no estarán obligados a tramitar el pedimento respectivo, siempre que proporcionen la información que establezca el Servicio de Administración Tributaria mediante reglas. En los demás casos, no se requerirá pedimento para la importación temporal de mercancías ni para su retorno, pero se deberá presentar la forma oficial que mediante reglas establezca el Servicio de Administración Tributaria. Tampoco será necesaria la presentación de pedimento cuando se presente otro documento con el mismo fin previsto en algún tratado internacional del que México sea parte. El Servicio de Administración Tributaria establecerá mediante reglas, los casos y condiciones en que procederá la utilización de ese documento, de conformidad con lo dispuesto en dicho tratado internacional»».
} 
En lo que sí concuerdo es en que "la finalidad" es el parámetro bajo el cual estableceremos si la mercancía se incorpora o no al circuito económico, pues no es lo mismo un menaje de casa, cuya intención no es establecer acto alguno de comercio, que la importación temporal de una maquinaria para producir un bien determinado.

Partiendo de la base de que la norma general en la importación temporal es la exención de impuestos, estudiemos los supuestos que dan origen a la imposición por importación temporal. El párrafo 2 del apartado I del artículo 104 de la Ley aduanera establece que no les será aplicable la exención de impuestos a los casos previstos en los artículos 63- A, 105, 108, fracción III, 110 y 112, por lo que bajo esté orden realizaremos el Estudio de los supuestos. 


\subsubsection{Draw Back}

El artículo 63-A de la Ley Aduanera establece lo siguiente:

"Quienes introduzcan mercancías al territorio nacional bajo un programa de diferimiento o de devolución de aranceles, estarán obligados al pago de los impuestos al comercio exterior que corresponda, de acuerdo con lo dispuesto en los Tratados de que México sea parte, en la forma que establezca la Secretaría mediante reglas».

Este sistema, mejor conocido en inglés como Draw Back, consiste en la devolución a los exportadores de los impuestos de importación pagados por la importación de bienes o insumos ${ }^{419}$ que se incorporan a mercancías de exportación o por las mercancías que se retornan en el mismo estado o por mercancías para su reparación o alteración ${ }^{420}$. Debe destacarse que este

\footnotetext{
${ }^{419}$ Conforme al Artículo 2 del Decreto que establece la devolución de impuestos de importación a los exportadores. De fecha 29 de Diciembre del 2000. Deberá entenderse por insumos: «a las materias primas, partes y componentes, empaques y envases, combustibles, lubricantes y otros materiales o mercancías de origen extranjero incorporados a las mercancías de exportación».
}

${ }^{420}$ Época: Décima Época. Registro: 2002246. Instancia: Tribunales Colegiados de Circuito. Tipo de Tesis: Aislada. Fuente: Semanario Judicial de la Federación y su Gaceta. Libro XV, diciembre de 2012, Tomo 2. Materia(s): Administrativa. Tesis: II.3o.A.28 A (10a.). Página: 1280. RUBRO: COMERCIO EXTERIOR. EL CAMBIO DE LOS PROGRAMAS DE IMPORTACIÓN TEMPORAL PARA PRODUCIR ARTÍCULOS DE EXPORTACIÓN (PITEX), A LOS DIVERSOS PROGRAMAS PARA LA INDUSTRIA MANUFACTURERA, MAQUILADORA Y DE SERVICIOS DE EXPORTACIÓN (IMMEX), DEBE CONSIDERARSE POR LOS ÓRGANOS JURISDICCIONALES AL ANALIZAR ASUNTOS QUE INVOLUCREN A EXPORTADORES QUE HUBIERAN SIDO TITULARES DE LOS PRIMEROS Y MIGRADO A LOS SEGUNDOS. Texto: «Los Programas de Importación Temporal para Producir Artículos de Exportación (también conocidos por su acrónimo PITEX) son instrumentos del derecho de comercio exterior 
programa es de aplicación casi exclusiva para importaciones y exportaciones en el marco del Tratado de Libre Comercio con América del Norte y se trata la más de las veces de exenciones parciales, pues sólo se puede devolver el menor del monto de aranceles que resulte al comparar el monto de aranceles de los insumos importados a México y el monto de aranceles pagados en los Estados Unidos de América o Canadá por el producto terminado.

En lo que respecta a la Unión Europea, el artículo 14, Título IV del Anexo III del Tratado de Libre Comercio entre la Comunidad Europea y México ${ }^{421}$ prohíbe la

utilizados para el fomento de las exportaciones, mediante los cuales se permite a los productores de mercancías destinadas a la exportación, importar temporalmente diversos bienes para ser utilizados en la elaboración de productos de exportación, sin que tal introducción cause el pago del impuesto general relativo (en la medida que lo dispongan los tratados internacionales celebrados por México), del impuesto al valor agregado y/o cuotas compensatorias si fueran aplicables, cuyo fundamento es el artículo 108 de la Ley Aduanera; sin embargo estos programas han cambiado paulatinamente a los diversos Programas para la Industria Manufacturera, Maquiladora y de Servicios de Exportación (IMMEX), según se advierte del séptimo acuerdo de la Secretaría de Economía por el que se dan a conocer los números correspondientes, publicado en el Diario Oficial de la Federación el 21 de diciembre de 2007, los cuales ahora se reconocen -incluso con posibilidades más amplias- como esquemas de facilidades administrativas otorgados por el Gobierno Federal para que se dé el proceso industrial de manufacturar, maquilar o prestar servicios destinados a la elaboración, transformación o reparación de mercancías de procedencia extranjera, importadas temporalmente, para su posterior retorno al extranjero; aspecto que debe considerarse por los órganos jurisdiccionales al analizar asuntos que involucren a exportadores que hubieran sido titulares de los programas inicialmente mencionados y migrado sus beneficios a los referidos en segundo lugar».

${ }^{421}$ Por cuestiones prácticas nos referimos a este instrumento como Tratado de libre Comercio, advirtiendo de que lo correcto es: "Acuerdo de Asociación Económica, Concertación Política y Cooperación entre los Estados Unidos Mexicanos y la Comunidad Europea y sus Estados Miembros, la Decisión del Consejo Conjunto de dicho Acuerdo; y la Decisión del Consejo Conjunto del Acuerdo Interino sobre Comercio y Cuestiones Relacionadas con el Comercio entre los Estados Unidos Mexicanos y la Comunidad Europea". 
devolución o exención de los aranceles de importación para materiales no originarios utilizados en la fabricación de aquellos bienes exportados a los países miembros de los Tratados para los cuales se haya expedido o elaborado una prueba de origen ${ }^{422}$.

Por consiguiente, la norma general es que no existirá retorno de impuestos y existe la obligación del pago de los impuestos a la importación. Así pues, el hecho imponible que surge por este concepto se da, como en cualquier otra

${ }^{422}$ TLC México - CE. Anexo III Título IV - Reintegro o Exención «Artículo 14 - Prohibición de devolución o exención de los aranceles de importación 1. Los materiales no originarios utilizados en la fabricación de productos originarios de la Comunidad o de México en el sentido del presente anexo, para los cuales se haya expedido o elaborado una prueba de origen de conformidad con lo dispuesto en el título V, no se beneficiarán en la Comunidad o México de la devolución o la exención de los aranceles de importación. 2. Para propósitos de este artículo, el término "aranceles de importación" incluye los aranceles aduaneros, tal y como se definen en el párrafo 8 del artículo 3 de la Decisión, cuotas antidumping y cuotas compensatorias aplicadas de conformidad con el artículo 14 de la Decisión. 3. La prohibición del párrafo 1 aplica a todas las disposiciones relativas a la devolución, la condonación o la falta de pago parcial o total de los aranceles de importación aplicables en la Comunidad o México a los materiales utilizados en la fabricación, si esta devolución, condonación o falta de pago se aplica, expresa o efectivamente, cuando los productos obtenidos a partir de esos materiales sean exportados y no cuando sean destinados al consumo nacional. 4. El exportador de productos amparados por una prueba de origen deberá estar preparado para presentar en cualquier momento, a petición de las autoridades aduaneras, todos los documentos apropiados que demuestren que no se ha obtenido ninguna devolución o reintegro respecto de los materiales no originarios utilizados en la fabricación de los productos de que se trate, y que se han pagado efectivamente todos los aranceles de importación aplicables a esos materiales. 5. Lo dispuesto en los párrafos 1 al 3 se aplicará también a los envases, en el sentido de lo dispuesto en el párrafo 2 del artículo 7 , accesorios, piezas de repuesto y herramientas, en el sentido de lo dispuesto en el artículo 9, y surtidos, en el sentido de lo dispuesto en el artículo 10, cuando estos artículos no sean originarios. 6. Lo dispuesto en los párrafos 1 al 4 se aplicará únicamente a los productos exportados que se beneficien de cualquier trato arancelario preferencial en la otra Parte. Más aún, no serán obstáculo para la aplicación de un sistema de restituciones a la exportación para los productos agrícolas. 7. Este artículo aplicará a partir del 1 de enero de 2003» 
importación, como consecuencia de la incorporación de la mercancía al circuito económico. La incorporación al circuito económico se realiza al momento de incorporar la mercancía en un proceso productivo dentro del circuito económico, por lo que se cumple el presupuesto de hecho.

Las exenciones totales o parciales, obedecen mayormente a convencionalidad, que como vimos repercute en el mayor o menor impacto de la mercancía en el circuito económico.

\subsubsection{Transferencia $o$ enajenación entre maquiladoras de mercancías destinadas al régimen de importación temporal.}

El segundo supuesto que contempla el artículo 104 como generador de tributos al comercio exterior en el régimen de importación temporal es el establecido en el artículo 105 de la Ley aduanera:

«La propiedad o el uso de las mercancías destinadas al régimen de importación temporal no podrá ser objeto de transferencia o enajenación, excepto entre maquiladoras, empresas con programas de exportación autorizados por la Secretaría de Economía y empresas de comercio exterior que cuenten con registro de esta misma dependencia, cuando cumplan con las condiciones que establezca el Reglamento».

Como se desprende del precepto señalado, tratándose de mercancías que se importan temporalmente, sólo podrán ser objeto de transferencia o enajenación entre sujetos autorizados por la Secretaría de Economía, es decir, que un particular o cualquier otra persona está imposibilitada para realizar cualquier 
tipo de transferencia de uso o propiedad, pues de hacerlo estaría en el supuesto de contrabando equiparado conforme lo establece el artículo 105 del Código Fiscal de la Federación.

Así pues, únicamente los productores de mercancías destinadas a la exportación, autorizados por la Secretaría de Economía, podrán en algunas ocasiones realizar estas operaciones de acuerdo lo señalan el artículo 108, fracción III, el 110 y 112 de la Ley Aduanera, las cuales a groso modo se refieren a transacciones de maquinaria, equipo y/o desperdicios.

Al realizarse la transacción de los bienes, estos se incorporan generalmente de forma limitada al circuito económico, pues aunque realizan operaciones económicas, éstas se realizan de forma restringida para ser reexportadas, por lo que también serán proporcionalmente menores los derechos arancelarios, en tanto el nivel de utilización del circuito económico es menor. Cuando la incorporación es total estaremos en presencia de una importación definitiva, aplicando por lo tanto lo correspondiente a ese régimen.

Viendo el conjunto de elementos y características que integran el supuesto de importación temporal, me parece difícilmente rebatible que la importación temporal se trata de un derecho (tasa) por prestación de servicios, pues en ningún momento el gravamen 0 exenciones hacen referencia a actos relacionados con capacidad contributiva o la ausencia de ésta. Por el contrario, toma elementos cualitativos como la finalidad de la importación y el origen, para determinar el nacimiento o no de la obligación tributaria, elementos que son irrelevantes para determinar la capacidad contributiva desde la perspectiva 
de la imposición, pero que sí son parámetros de medición del mayor o menor impacto de la mercancía en la economía. Concuerda por tanto, y como ya vimos en el hecho imponible genérico, con los sistemas de determinación de la proporcionalidad en los derechos por utilización de bienes de dominio público: distintos grados de aprovechamiento, beneficio, de la valoración de su mayor o menor disponibilidad o su reparación o reconstrucción, si se produce un deterioro $^{423}$. En definitiva, al igual que en el hecho imponible genérico considero que estamos en presencia de un Derecho por utilización de bienes de dominio público.

\footnotetext{
${ }^{423}$ Ver al respecto la ya citada jurisprudencia Época: Novena Época. Registro: 165045. Instancia: Segunda Sala. Tipo de Tesis: Jurisprudencia. Fuente: Semanario Judicial de la Federación y su Gaceta Tomo XXXI, Marzo de 2010. Materia(s): Constitucional, Administrativa. Tesis: 2a./J. 27/2010. Página: 1031. Rubro: DERECHOS POR USO O APROVECHAMIENTO DE BIENES DEL DOMINIO PÚBLICO DE LA NACIÓN. ELEMENTOS PARA DETERMINAR SU PROPORCIONALIDAD Y EQUIDAD.
} 
Carlos Gerardo Herrera Orozco 320

“El nacimiento de la deuda aduanera en la Unión Europea y México. Estudio comparado" 


\subsection{La importación irregular.}

En el Derecho aduanero mexicano la introducción irregular de mercancías no representa un régimen de importación sino un delito tipificado en el artículo 102 del Código Fiscal de la Federación como "Contrabando"424, que supone el incumplimiento de obligaciones formales y/o materiales a las que está sujeta toda importación en sus diferentes regímenes.

Al realizarse el hecho imponible de la importación, nace la obligación tributaria de forma independiente de la penalidad que proceda por el incumplimiento de las obligaciones $^{425}$, «por lo que las autoridades administrativas, con arreglo a las leyes

${ }^{424}$ Código Fiscal de la Federación. "Artículo 102.- Comete el delito de contrabando quien introduzca al país o extraiga de él mercancías:

I. Omitiendo el pago total o parcial de las contribuciones o cuotas compensatorias que deban cubrirse.

II. Sin permiso de autoridad competente, cuando sea necesario este requisito.

III. De importación o exportación prohibida.

También comete delito de contrabando quien interne mercancías extranjeras procedentes de las zonas libres al resto del país en cualquiera de los casos anteriores, así como quien las extraiga de los recintos fiscales o fiscalizados sin que le hayan sido entregados legalmente por las autoridades o por las personas autorizadas para ello».

${ }^{425}$ RODRÍGUEZ LOBATO, R. Derecho fiscal. 2ª Ed. México: Oxford, 2005, p.118 «En cuanto a la realización del hecho imponible, no sólo los hechos lícitos pueden considerarse como hechos generadores, sino también los ilícitos. Esto es así no porque en el Derecho Fiscal prive un concepto ético distinto al de las otras ramas del Derecho, sino porque para la tributación lo que interesa es sólo el aspecto económico del hecho generador, por cuanto sirve de índice de la capacidad contributiva, u, además, porque sería contrario al principio de igualdad y, por lo tanto, 
Carlos Gerardo Herrera Orozco

“El nacimiento de la deuda aduanera en la Unión Europea y México. Estudio

comparado"

fiscales, podrán hacer efectivas las contribuciones omitidas, los recargos y las sanciones administrativas correspondientes, sin que ello afecte el procedimiento penal ${ }^{426}$

De lo anterior se evidencia que no estamos en presencia de forma de nacimiento alguna de deuda aduanera, por lo que la naturaleza jurídico- tributaria será la que corresponda al régimen aduanero al que debió de incorporarse la mercancía de acorde a su tipo y destino. Las particularidades de las sanciones, como su tipificación, procedencia o improcedencia, atenuantes, determinación, etc., son tópicos que por sí mismos nos llevarían a un estudio completo de distinta naturaleza al que nos ocupa, razón por la cual no los abordamos.

injusto que los contraventores de la ley estuvieran en ventaja respecto de quienes cumplen con la ley y quedaran exonerados del pago del tributo, no obstante que ambos realizan el hecho imponible, por la sola razón de que uno lo hizo mediante un hecho lícito y el otro mediante uno ilícito. Así, por ejemplo, el impuesto de importación se causa no sólo por las mercancías que se introducen legalmente al país, sino también por las que entran de contrabando»

426 Época: Novena Época. Registro: 163001. Instancia: Primera Sala. Tipo de Tesis: Jurisprudencia. Fuente: Semanario Judicial de la Federación y su Gaceta. Tomo XXXIII, enero de 2011. Materia(s): Penal. Tesis: 1a./J. 87/2010. Página: 423. RUBRO: SANCIÓN PECUNIARIA TRATÁNDOSE DE DELITOS FISCALES. EL ARTÍCULO 94 DEL CÓDIGO FISCAL DE LA FEDERACIÓN, DEROGADO MEDIANTE DECRETO PUBLICADO EN EL DIARIO OFICIAL DE LA FEDERACIÓN EL 28 DE JUNIO DE 2006, AL PREVER QUE LA AUTORIDAD JUDICIAL NO IMPONDRÁ AQUÉLLA, CONTIENE UN DERECHO SUSTANTIVO QUE DEBE APLICARSE ULTRACTIVAMENTE A FAVOR DEL GOBERNADO, EN CUMPLIMIENTO AL PRINCIPIO DE EXACTA APLICACIÓN DE LA LEY. 


\section{CAPÍTULO 5. CONCLUSIONES.}

Estudiar el nacimiento de la deuda aduanera en Europa me familiarizó con un sistema jurídico novedoso y en proceso de consolidación. Aunque parezca contradictorio por la relevancia política, económica y jurídica que implica, el Derecho Aduanero Comunitario es todavía el gran desconocido en este proceso de integración, porque la delimitación de competencias no queda aún clara para muchos Estados miembros, especialmente a la hora de ejercer facultades legislativas en materia de gestión y procedimientos aduaneros que han llevado, en muchos casos, a un vacío legislativo en este rubro, creando con ello importantes diferencias en su aplicación entre los distintos Estados miembros. Vacíos que, como vimos en el Capítulo I, han tenido ya repercusiones internacionales; ejemplo de esto, es el procedimiento de solución de diferencias tramitado ante la Organización Mundial de Comercio bajo el expediente DS 315.

El análisis de esta realidad nos reveló la necesidad de unificar la normativa de gestión y recaudación de los tributos aduaneros pues, siendo la composición del Derecho aduanero, en su mayor parte, disposiciones de carácter formal, es indispensable evitar distorsiones al momento de su aplicación, por lo que se requiere que sea el Parlamento Europeo el que legisle al respecto; sin importar que su gestión siga aun a cargo del personal de los Estados miembros.

Por otra parte pudimos observar que el Código aduanero está indebidamente fundamentado en el artículo 95 CE, pues como quedó demostrado en el capítulo I, 
el Código aduanero se refiere a disposiciones fiscales en los términos del apartado 67 de la sentencia del TJCE, de fecha 29 de abril de 2004, Comisión/Consejo (C338/01, Rec. p. I-4829), por lo que al igual que en el caso expuesto en la referida sentencia, el artículo 95 CE no es la base jurídica adecuada para la adopción de los códigos aduaneros tanto de 1992 como el modernizado de 2008, debiendo haber sido adoptados con base en los artículos 93 y $94 \mathrm{CE}$, en virtud del carácter impositivo de los derechos arancelarios. En consecuencia, debería de decretarse la nulidad de ambos ordenamientos en los términos de artículo 264 del TFUE.

En cuanto a la legislación mexicana, encontramos una dispersión de las normas aduaneras que hace difícil su manejo, causando confusiones en su aplicación y cumplimiento, por lo que considero necesario realizar una codificación para facilitar su consulta y aplicación, brindando certeza a todas las partes que intervienen en los procesos aduaneros.

El estudio de los supuestos generadores de la deuda aduanera me llevó a resultados análogos entre la Unión Europea (Capítulo 2) y México (Capítulo 4.3). Las diferencias destacables no son de fondo, sino de carácter terminológico y, algunas otras, son propias de la naturaleza supranacional de la Unión; mismas que desarrollaremos a continuación.

1. El hecho generador.

Tanto la legislación de la Unión Europea, como la de México contienen varios supuestos que generan deuda aduanera, cada uno de ellos con particularidades 
específicas en cuanto al uso, destino, temporalidad y modo de ingreso; pero todos y cada uno de ellos comparten un elemento objetivo común que denominamos "hecho imponible genérico".

En todos los supuestos generadores, el elemento objetivo común es la incorporación de la mercancía al circuito económico, como lo puso de manifiesto expresamente la Sentencia del Tribunal de Justicia de la Comunidad Europea (Sala Tercera) de 29 de abril de 2010, en el asunto C-230/08, Dansk Transport og Logistiky Skatteministeriet, apartado 91, debiendo entender por "circuito económico" la actividad económica (transacciones de bienes y servicios) que se realiza en un país o economía determinada. Por lo que la incorporación de una mercancía al circuito económico equivale a la factibilidad de que la mercancía importada pueda ser objeto de comercialización o consumo en el espacio físico del país o economía de que se trate.

Este fenómeno lo encontramos también en el Derecho aduanero mexicano pues, si bien ni la legislación ni la jurisprudencia establecen expresamente la incorporación al circuito económico como hecho generador del tributo aduanero, la interpretación sistemática y funcional de la ley aduanera nos permite arribar a esa conclusión. Aun cuando el artículo 51 de la Ley Aduanera establece como objeto de tributación la entrada de mercancía al territorio nacional, el artículo 61 de la ley en mención, establece un extenso dictado de mercancías exentas del pago de impuestos al comercio exterior, las cuales tienen como común denominador que por su naturaleza, valor, cantidad o finalidad no son sujetas de comercio. Con ello 
que se demuestra que no es el simple cruce de fronteras lo que provoca el nacimiento de la deuda tributaria sino que, al igual que en el caso europeo, la integración de la mercancía a la economía nacional es el elemento objetivo del hecho imponible, lo que CARVAJAL CONTRERAS ${ }^{427}$ denomina "integración económica de la mercancía", lo cual es exactamente lo mismo que la integración al circuito económico.

Este hecho generador, inexplorado por la mayor parte de la doctrina, me llevó a plantearme dos elementos sustanciales: en primer lugar, la naturaleza jurídica del mercado o economía donde se desarrolla el circuito económico y, en segundo lugar, la naturaleza jurídico-tributaria de la prestación económica requerida por tal concepto.

2. Naturaleza jurídica del mercado o economía.

La Unión Europea está forjada bajo un esquema jurídico-económico en el que la mayor parte del Tratado de Funcionamiento de la Unión y tratados predecesores tienen un espíritu de regulación netamente económico, cuyo objetivo primordial es la consecución de la unión económica, tal y como se planteó en el primer capítulo en lo referente a las competencias de la Unión.

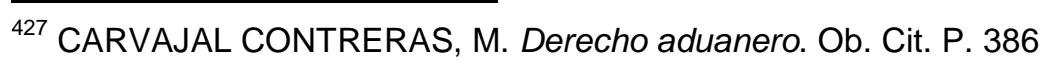


El mercado interior ${ }^{428}$ es el fundamento y la esencia de la Comunidad Europea, espacio en el que se desarrolla el intercambio de bienes, servicios y capital entre los distintos actores del circuito (consumidores, productores, vendedores), al

${ }^{428}$ Definiciones: Art. 26. 2 TFUE «El mercado interior implicará un espacio sin fronteras interiores, en el que la libre circulación de mercancías, personas, servicios y capitales estará garantizada de acuerdo con las disposiciones de los Tratados».STJCE defecha05 de mayo de 1982, asunto C15/81, Caso: Shul, apartado 33, «(...) the concept of a common market as defined by the court in a consistent line of decisions involves the elimination of all obstacles to intra-community trade in order to merge the national markets into a single market bringing about conditions as close as possible to those of a genuine internal market.It is important that not only commerce as such but also private persons who happen to be conducting an economic transaction across national frontiers should be able to enjoy the benefits of that market". LÓPEZ ESCUDERO, M. "El mercado interior: cuestiones generales". En: LÓPEZ ESCUDERO, M. MARTÍN Y PÉREZ DE NANCLARES, J. y otros. Derecho comunitario material. Ob. Cit. P.29 «El mercado interior se identifica, por tanto, con un espacio económico unificado sin fronteras interiores y con la libertad de circulación de los factores productivos en condiciones de competencia no falseada. En definitiva, la circulación de mercancías, personas, servicios y capitales entre los Estados miembros debe de realizarse en condiciones similares a las existentes en un mercado nacional». MATTERA, A. El mercado único europeo sus reglas de funcionamiento. Ob. Cit. P. 42. Define el mercado interior como: «un espacio económico común a los Estados que componen la Comunidad, en el marco del cual los ciudadanos y los agentes económicos (ya se trate de personas físicas o jurídicas) deben poder actuar libremente, gozando de los Derechos que les reconocen las reglas previstas por el propio Tratado, o establecidas al amparo de las disposiciones de éste, relativas a las cuatro libertades fundamentales de la Comunidad: la libre circulación de mercancías, personas, servicios y capitales. (....) Dichas reglas pretenden, por otra parte, el desarrollo de políticas comunes y de normas armonizadas en los distintos sectores de la vida económica con objeto de completar los resultados obtenidos al amparo de las disposiciones anteriormente mencionadas y de conseguir, así, una liberalización de los intercambios, en el seno de ese espacio económico común, comparable a la que rigen en el territorio nacional»». 
amparo de las cuatro libertades fundamentales que consagra el mercado interior: libre circulación de personas, bienes, capitales y servicios ${ }^{429}$.

De la fragmentación de los elementos esenciales que lo integran, se desprenden dos conceptos torales: en primer lugar, su referencia a un espacio físico territorial, en el que se garantiza la realización de sus otros elementos en forma de libertades, políticas y principios. Al hablar de un espacio físico, hablamos de un bien determinado del Estado, como lo es el territorio. En segundo término, el resto de sus elementos conforman bienes de carácter inmaterial que conjuntamente identifican al mercado común como una parte inherente a la propia Unión, pues basta con revisar cualquiera de los Tratados constitutivos ${ }^{430} 0$ la reciente Comunicación de la Comisión «COM(2012) $573 »{ }^{431}$ para verificarlo.

Resulta evidente que el mercado forma parte inherente al Estado y, en este caso, a la Unión Europea; resulta innecesario buscar la naturaleza de algo que es intrínseco a sí mismo, pues sea cual sea la teoría en torno a la naturaleza de los bienes demaniales, todas coinciden en que un bien de dominio público es algo que por su propia naturaleza es inherente al Estado, por lo cual se confirma el de bien de dominio público que tiene el mercado interior.

\footnotetext{
${ }^{429}$ Ver. Diagrama Anexo.

${ }^{430}$ Verbigracia: Artículos 2, 3, 4, 14... todos del Tratado de la Comunidad Europea

431 Bruselas, 3.10.2012 COM (2012) 573 final. COMUNICACIÓN DE LA COMISIÓN AL PARLAMENTO EUROPEO, AL CONSEJO, AL COMITÉ ECONÓMICO Y SOCIAL EUROPEO Y AL COMITÉ DE LAS REGIONES. Acta del Mercado Único II Juntos por un nuevo crecimiento.
} 
En el caso del derecho mexicano, la economía comprende una serie de bienes intangibles de interés público, inherentes a la estructura política y social de la Federación, en apego a los artículos 25, 26 y 28 de la Constitución Política de los Estados Unidos Mexicanos, sobre los cuales ejerce directa e indirectamente poderes de dominio en forma de posesión, administración y regulación. Por lo cual y según lo visto en el artículo 4.3 de esta tesis, es considerada un bien de dominio público federal de carácter intangible.

3. Naturaleza jurídico-tributaria de los tributos a la importación.

En México la doctrina consultada no se ocupa del tema de la naturaleza tributaria de los derechos arancelarios ${ }^{432}$, prefiriendo quedarse lisa y llanamente con la clasificación de "impuesto" que le otorga la propia Ley Aduanera. En el caso de Europa partimos del hecho que el Código Aduanero Modernizado y ninguna otra norma de la Unión Europea encasillan los derechos de importación dentro de una clasificación específica de tributos.

Como expusimos en el cuerpo de esta tesis, el debate doctrinal respecto de la naturaleza tributaria de los tributos a la importación ha sido una constante en los últimos años, habiendo acordado en los puntos anteriores que tanto en la Unión Europea como en México: a) El hecho imponible de la importación consiste en la entrada de una mercancía extranjera al circuito económico o economía interna

\footnotetext{
${ }^{432}$ Salvo algunos casos puntuales que hacen referencia a algunos autores europeos, también citados en esta tesis.
} 
(Comunitaria o nacional, según sea el caso); b) El mercado o economía es considerada un bien de dominio público.

Iniciamos nuestro análisis de la naturaleza jurídico-tributaria bajo estos dos parámetros, contrastando las diversas posturas en torno a su naturaleza jurídicotributaria, tanto doctrinales, como de Derecho positivo, llegando a la conclusión que en ambos casos estamos en presencia de una tasa o derecho por utilización de un bien de dominio público.

La utilización especial del bien de dominio público denominado "mercado", se produce de la siguiente forma: la Unión o el Estado, en su caso, crean las condiciones propicias para el intercambio de bienes y servicios, que beneficien a todos, procurando el desarrollo nacional, ejerciendo su actividad rectora con el fin de mantener, equilibrar y facilitar ese sistema de intercambios. Al ingresar una mercancía exógena a la economía, se sirve de las condiciones propiciadas por el Estado, las cuales de no existir sería imposible que se llevaran a cabo los intercambios comerciales, por lo que al servirse de ellas se está haciendo uso de un bien de dominio público como es el circuito económico. Si bien todas las mercancías utilizan el mismo bien denominado "mercado", el grado de utilización, es decir, el impacto del mercado es distinto dependiendo el tipo de mercancías, origen y el destino de cada una de ellas.

Como vimos en el capítulo II, el "mercado" tiene múltiples acepciones, pero todas ellas siempre describen un bien limitado por su propia naturaleza (territorial, 
sectorial, productiva, etc.). Esa limitación propia del mercado, hace que el acceso al circuito económico (intercambio de bienes y servicios) sea preferente para los productos que se generan internamente y que puedan competir entre sí en igualdad de términos y condiciones para sostener un equilibrio, pues cualquier desigualdad causaría un desequilibrio en el mercado que repercutiría en perjuicio de la colectividad, por lo que la entrada de una mercancía extranjera a este circuito económico puede causar un perjuicio al interior del mercado, ya sea por traer un precio más bajo que el producto nacional, o bien saturar el mercado y no dejar espacios para los productos nacionales. Cuando hay una sobreproducción, o escasea cierta materia prima, es necesario relacionarse con otros mercados a fin de compensar las necesidades del mercado y conseguir un equilibrio. Cuando el flujo es constante entre los mercados se mantiene un equilibrio, pero si el flujo es de distinta intensidad o en un solo sentido, se satura el mercado receptor y puede colapsar su economía, de igual forma la ausencia de cierta materia prima en el mercado interior puede ocasionar el mismo efecto devastador.

Por último, cabría realizar unas propuestas concretas, que deberían ser tenidas en cuenta por el legislador oportuno, en el siguiente sentido:

1. Es necesario crear en la Unión Europa una legislación única en torno a la gestión y recaudación de los tributos aduaneros, a efectos de evitar diferencias de aplicación, que genere desequilibrios al comercio exterior.

2. Es conveniente cambiar el fundamento del Código Aduanero Modernizado del artículo 95 CE, a los artículos 93 y 94 CE, dada la naturaleza fiscal del 

comparado"

Código y para no afectar la validez de los actos sustentados en el referido código.

3. Es necesaria la codificación en México de la legislación aduanera nacional, ahora tan dispersa, a efectos de dotar de certeza jurídica a todos los que en ella intervienen.

4. Las diferencias sustanciales entre la normativa de México y la Unión Europea en materia de deuda aduanera son de carácter netamente conceptuales, siendo lo más práctico ajustar ambas legislaciones a los conceptos establecidos por la Organización Mundial de Comercio y a la Organización Mundial de Aduanas. 


\section{ANEXO I}

En el diagrama están representadas las cuatro libertades que garantiza el mercado interior en el espacio físico que ocupa (Territorio de la Unión Europea) y en el que se puede observar el circuito económico al centro de dichas libertades, ya que como hemos venido sosteniendo, el circuito económico es consecuencia directa del ejercicio y cumplimiento de las referidas libertades, pues el incumplimiento de cualquiera de ellas inmediatamente rompería con el circuito.

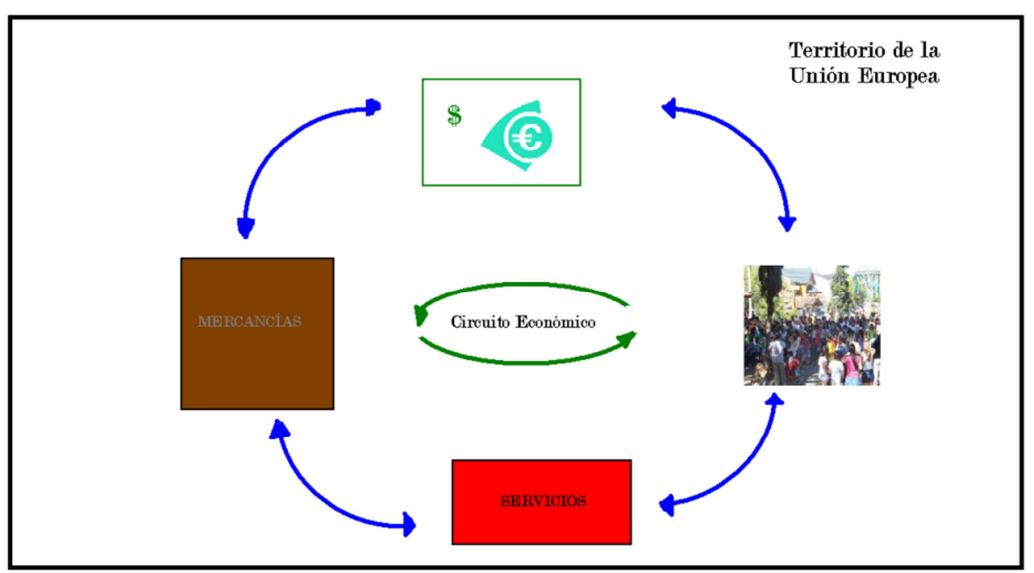

A fin de reforzar lo anterior, permítaseme el utilizar un diagrama más, en el que se esquematiza en qué consiste un circuito económico y podamos contrastar nuestra postura $^{433}$. En el esquema se puede observar el flujo de bienes, capitales y

\footnotetext{
${ }^{433}$ Diagrama obtenido de la página web: http://iutateoriaeconomica.blogspot.es/
} 


\section{Carlos Gerardo Herrera Orozco $\mid 334$ \\ “El nacimiento de la deuda aduanera en la Unión Europea y México. Estudio comparado"}

servicios, por lo que si nosotros restringiéramos cualquiera de ellos inmediatamente se rompería el circuito.

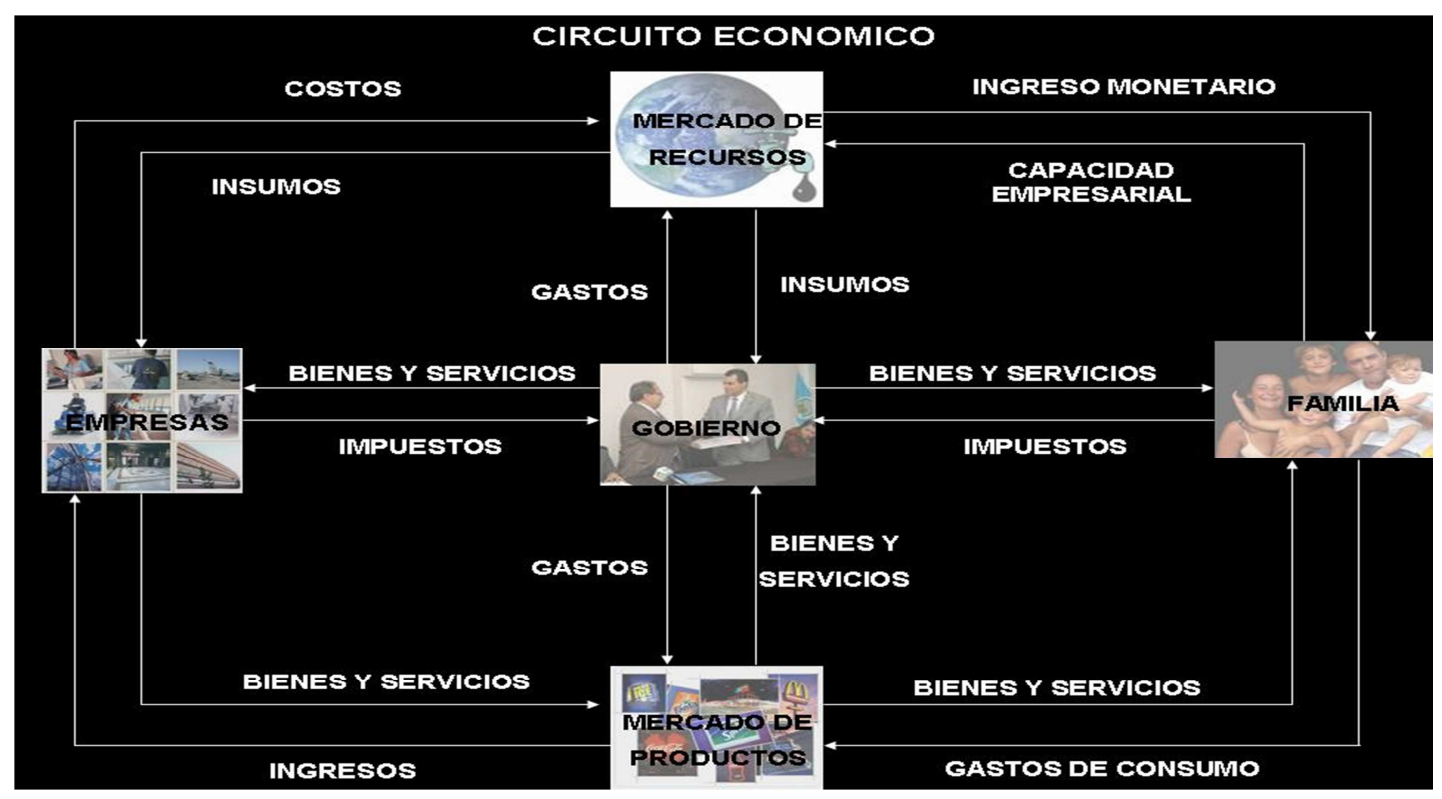


\begin{tabular}{l|l} 
Carlos Gerardo Herrera Orozco & 335
\end{tabular}

“El nacimiento de la deuda aduanera en la Unión Europea y México. Estudio comparado" 


\section{Carlos Gerardo Herrera Orozco “El nacimiento de la deuda aduanera en la Unión Europea y México. Estudio \\ comparado"}

\section{ANEXO II}

\begin{abstract}
Código aduanero
Artículo 38

1. Las mercancías que se introduzcan en el territorio aduanero de la Comunidad deberán ser trasladadas sin demora por la persona que haya efectuado dicha introducción, utilizando, en su caso, la vía determinada por las autoridades aduaneras y según las modalidades establecidas por dichas autoridades:

a) bien a la aduana designada por las autoridades aduaneras o a cualquier otro lugar designado o autorizado por dichas autoridades;

b) bien a una zona franca, cuando la introducción de las mercancías en dicha zona franca deba efectuarse directamente:

- bien por vía marítima o aérea,

- bien por vía terrestre sin pasar por otra parte del territorio aduanero de la Comunidad, cuando se trate de una zona franca contigua a la frontera terrestre entre un Estado miembro y un país tercero.
\end{abstract}

\section{CAM \\ Artículo 92 Traslado al lugar apropiado}

1. La persona que introduzca mercancías en el territorio aduanero de la Comunidad las trasladará sin demora, utilizando, en su caso, la vía determinada por las autoridades aduaneras y según las modalidades establecidas por dichas autoridades, bien a la aduana designada por las autoridades aduaneras o a cualquier otro lugar designado o autorizado por dichas autoridades, bien a una zona franca.

Las mercancías introducidas en una zona franca serán introducidas directamente en dicha zona franca, bien por vía marítima o aérea o, en caso de que sea por vía terrestre, sin pasar por otra parte del territorio aduanero de la Comunidad, cuando se trate de una zona franca contigua a la frontera terrestre entre un Estado miembro y un tercer país.

Las mercancías serán presentadas a las autoridades aduaneras, de conformidad con el artículo 95.

\section{Artículo 93 Servicios aéreos y marítimos} intracomunitarios

1. Los artículos 87 a 90, el artículo 92, apartado 1, y los artículos 94 a 97 no se aplicarán a las mercancías que hayan abandonado temporalmente el territorio aduanero de la Comunidad circulando entre dos puntos de la Comunidad por vía marítima o aérea siempre y cuando el transporte se haya efectuado en línea directa por un avión o un barco de línea regular sin escala fuera del territorio aduanero de la Comunidad.

\section{Artículo 39}

1. Cuando, por caso fortuito o fuerza mayor, no pueda cumplirse la obligación prevista en el apartado 1 del artículo 38, la persona sujeta a dicha obligación, o cualquier otra persona que actúe en su lugar, informará sin demora a las autoridades aduaneras de dicha situación. Cuando el caso fortuito o de fuerza mayor no haya ocasionado la pérdida total de las mercancías, se deberá además informar a las autoridades aduaneras del lugar exacto en el que se hallen dichas mercancías.

2. Cuando, por caso fortuito o fuerza mayor, los buques o aeronaves contemplados en el apartado 6 del artículo 38 se vean obligados a hacer escala o detenerse de forma temporal en el territorio aduanero de la Comunidad sin poder cumplir la obligación prevista en el apartado 1 del artículo 38, la persona que haya introducido el buque o aeronave en el citado territorio aduanero, o cualquier otra persona que

\section{Artículo 94 Traslado en circunstancias especiales}

1. Cuando, por caso fortuito o fuerza mayor, no pueda cumplirse la obligación establecida en el artículo 92, apartado 1, la persona vinculada por dicha obligación o toda otra persona que actúe en nombre de dicha persona informará a las autoridades aduaneras de la situación sin demora. Cuando el caso fortuito o de fuerza mayor no haya ocasionado la pérdida total de las mercancías, se deberá además informar a las autoridades aduaneras del lugar exacto en el que se hallen dichas mercancías. 2. Cuando por caso fortuito o fuerza mayor, los buques o aeronaves contemplados en el artículo 92, apartado 5, se vean obligados a hacer escala o detenerse de forma temporal en el territorio aduanero de la Comunidad sin poder cumplir la obligación prevista en el artículo 92, apartado 1, la persona que haya introducido el buque o aeronave en el territorio aduanero de la Comunidad, o cualquier otra persona que actúe en su lugar, informará sin demora de esta situación a las autoridades 


\section{Carlos Gerardo Herrera Orozco

actúe en su lugar, informará sin demora de esta
situación a las autoridades aduaneras.
Artículo 40
Las mercancías que entren en el territorio aduanero
de la Comunidad serán presentadas en aduana por la
persona que las introduzca en dicho territorio o, si
procede, por la persona que se haga cargo de su
transporte tras su introducción, salvo en el caso de las
mercancías transportadas en medios de transporte que
se limiten a atravesar las aguas territoriales o el
espacio aéreo del territorio aduanero de la
Comunidad sin hacer escala en él. La persona que
presente las mercancías hará referencia a la
declaración sumaria o a la declaración de aduanas
presentada previamente en relación con las
mercancías.

Artículo 41

El artículo 40 no será obstáculo para la aplicación de disposiciones específicas relativas a las mercancías:

a) transportadas por viajeros;

b) incluidas en un régimen aduanero, sin ser presentadas en la aduana.

\section{Artículo 177}

Sin perjuicio de las disposiciones particulares adoptadas en el marco de normativas aduaneras específicas, las mercancías que salgan de una zona franca o de un depósito franco podrán ser:

- exportadas o reexportadas fuera del territorio aduanero de la Comunidad;

— introducidas en las demás partes del territorio aduanero de la Comunidad. aduaneras.

Artículo 95 Presentación de las mercancías en aduana

1. Las mercancías introducidas en el territorio aduanero de la Comunidad serán presentadas en aduana inmediatamente después de su llegada a cualquier aduana designada o a cualquier lugar

designado o aprobado por las autoridades aduaneras o a una zona franca por una de las siguientes personas:

a) la persona que introdujo las mercancías en el territorio aduanero de la Comunidad;

b) la persona en cuyo nombre o por cuya cuenta actúe la persona que introdujo las mercancías en dicho territorio;

c) la persona que asumió la responsabilidad por el transporte de las mercancías después de que fueran introducidas en el territorio aduanero de la Comunidad.

2. Sin perjuicio de las obligaciones de la persona descrita en el apartado 1, la presentación de las mercancías podrá ser efectuada en su lugar por una de las siguientes personas:

a) toda persona que incluya inmediatamente las mercancías en un régimen aduanero;

b) el titular de una autorización para el funcionamiento de almacenes de depósito o toda persona que realice una actividad en una zona franca.

3. La persona que presente las mercancías hará referencia a la declaración sumaria de entrada o a la declaración en aduana que haya sido presentada respecto de las mercancías.

4. El apartado 1 no impedirá la aplicación de disposiciones especiales en materia de cartas, postales e impresos, así como sus equivalentes electrónicos contenidos en otros medios, o de mercancías transportadas por los viajeros, mercancías transportadas en las zonas fronterizas o por conductos o hilos o cualquier otro tráfico de escasa importancia económica, siempre que la vigilancia aduanera y las posibilidades de control aduanero no se vean comprometidas por ello. Artículo 160 Salida de las mercancías de una zona franca

Sin perjuicio de la legislación vigente en otros ámbitos distintos del aduanero, las mercancías que se encuentren en una zona franca podrán ser exportadas o reexportadas fuera del territorio aduanero de la Comunidad, o introducidas en otra parte de dicho territorio.

Los artículos 91 a 98 se aplicarán mutatis mutandis a las mercancías introducidas en otras partes del territorio aduanero de la Comunidad. 



\section{BIBLIOGRAFÍA}

\section{LIBROS:}

- ABAJO ANTON, L.M. El despacho aduanero.1a Ed. Madrid: Fundación Cofemental, 2000.

- acosta ROMERO, M. Derecho administrativo especial.4a Ed. México: Porrúa, 2001.

- Agulló agüERO, A. La renta de Aduanas: configuración técnico jurídica y aspectos penales. 1aㅡ. Ed. Madrid: IEF, 1978.

- albiñana GaRcía, C. Sistema tributario español y comparado. Madrid: Tecnos, 1992.

- AMATUCCI, A. y GONZÁlez GARCÍA, E. "El concepto de Tributo", en: AMATUCCI, A.(Coordinador). Tratado de Derecho Tributario. $1^{\underline{a}}$ Ed. Bogota: Temis, 2001.

- ANDERSEN, A. Diccionario de economía y negocios. Madrid: España Siglo XXI, 1999.

- ARREOLA, L. y otros. Enciclopedia Española de Derecho y Administración ó Nuevo teatro Universal de la Legislación de España é Indias. Tomo II. Madrid: Imprenta de los Señores Andrés y Diaz, 1849, P. 347-348.

- bandeiRA DE MELLO, C.A. Curso de Derecho administrativo. LABRAÑA PARRA, V.E. (Trad.).1aㅡ. México: Porrúa y UNAM, 2006.

- BASALDUA, R.X. "Gravámenes al comercio exterior". En: INSTITUTO COLOMBIANO DE DERECHO TRIBUTARIO. Memorias / XXX Jornadas Colombianas de Derecho Tributario, Cartagena de Indias, 16, 17 Y 18 de Febrero de 2006. 1a Ed. Bogotá: Instituto Colombiano de Derecho Tributario, 2006.

- BEGG,D. FISCHER, S. DORNBUSCH, R. y FERNÁNDEZ DÍAZ, A. Economía. 8ª Ed. Madrid: McGraw Hill, 2006. 
- BERLIRI, A. Principios de Derecho tributario, Volumen II. AMORÓS RICA, N. (Trad. y Prol.); GONZÁLEZ GARCÍA, E. (Trad. y Prol). Madrid: Editorial de Derecho Financiero, 1971.

- beRMEJO VERA, J. - GARCÉS, A. - gaRCía ALVAREZ, G. - GIMENO, J.M. - OLIVÁN, J. - TEJEDOR, J.C. - TENA.V. Derecho administrativo parte especial. $1^{\underline{a}}$ Ed. Madrid: Civitas, 1994, p. 307.

- BERR, C,J. y TRÉMEAU, H. Le droit douanier Communautaire et national. 6르. Ed. Paris : Economica, 2004.

- BIELSA, R. Derecho Administrativo. Tomo III. 6ª Ed. Buenos Aires: La Ley, 1964.

- BREÑa CRUZ, F.A. La imposición sobre la Circulación de Bienes. En: Teoría de la Hacienda Pública. Madrid: Escuela de Inspección Financiera y Tributaria, Ministerio de Hacienda, 1982.

- CABELlo PERÉZ, M. Las aduanas y el comercio internacional. 1ํㅡ. Madrid: ESIC, 2000.

- Calvo ortega, R. Curso de derecho financiero I. Derecho tributario parte general. 6ª Ed. Madrid: Civitas, 2002.

- CAÑAS CARBALLIDO, M.: "La gestión del arancela aduanero comunitario y de la economía arancelaría en el marco de la Unión aduanera de la CEE". En: La aduana ante las Comunidades Europeas. $1^{\circ}$ Ed. Madrid, Ministerio de Hacienda, Instituto de Estudios Fiscales, 1984.

- CARRILlO SALCEDO, J.A. Curso de Derecho Internacional Público. 1aㅡ Ed. Madrid: Tecnos, 1999.

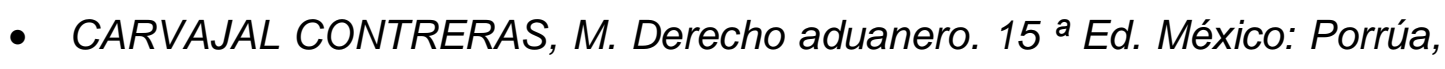
2009.

- Casado ollero, G. "Ordenamiento comunitario europeo y ordenamiento tributario interno". En JIMÉNEZ GONZÁLEZ, A (Coordinador). Grandes temas del Derecho tributario. 1aㅡ Ed. Guadalajara, Jalisco, México: Unidad Editorial Gobierno del Estado de Jalisco, 1995. 
- CAYON GALIARDO, A.; MARTÍN QUERALT, J.; y TEJERIZO LOPEZ, J.M. (Directores). Manual de Derecho Tributario parte especial. $2^{a}$ Ed. Navarra: Thomson Aranzadi, 2004.

- CLAVIJO HERNÁNDEZ, F. Curso de Derecho Tributario, parte especial. Madrid: Marcial Pons, 2002.

- CRUZ BARNEY, O. El Comercio exterior de México, 1821 -1928. 1aㅡ Ed. México: UNAM Instituto de Investigaciones Jurídicas, 2005.

- CUtRera, A. Principi di diritto e politica Doganale. $1^{a}$ Ed. Padova: CEDAM, 1941.

- D'AMATI. "El derecho tributario" en: AMATUCCl, A.(Coordinador) Tratado de Derecho Tributario. 1aㅡ Ed. Bogotá: Temis, 2001.

- DATTOLA, S.Istituzioni di diritto e tecnica doganale. A. Milan: Giuffrè, 1983.

- DE LA GARZA, S.F. Derecho Financiero Mexicano. 28ª Ed. México: Porrúa, 2010.

- DELGADILLO GUTIÉRREZ, L.H. y LUCERO ESPINOSA, M. Elementos de derecho administrativo segundo curso. 1를. México: Limusa, 2002.

- DI LORENZO, M. Corso di diritto doganale. Vol. I. Ed. $1^{a}$ Ed. Milan: Dott. A. Giuffré editore, 1947.

- DI LORENZO, M. Inztituzioni di diritto Doganale. Vol 2. Roma: Guido Pastena Editore, 1958.

- FALCÓN Y TELLA, R. Introducción al derecho financiero y tributario de las Comunidades Europeas. 1aㅡ Ed. Madrid: Civitas, 1988.

- FERLAZZO NATOLI. "El hecho imponible". Traducido por: CHAMORRO Y ZARZA, J.A. En: AMATUCCI.A. Tratado de Derecho tributario. Tomo II. $1^{\underline{a}}$ Ed. Bogotá - Colombia: Temis, 2001.

- FERNÁNDEZ RUÍZ, J. El Estado empresario. 1a Ed. México: Instituto de Investigaciones Jurídicas UNAM, 1982. 
- FERREIRO LAPATZA, J.F. Curso de Derecho tributario parte especial: sistema tributario. Los tributos en particular. $18^{\underline{a}}$ Ed. Madrid: Marcial Pons, 2002.

- FRAGA, G. Derecho administrativo. 48름. México: Porrúa, 2012.

- galeRA RODRIGo, S. Derecho Aduanero Español y Comunitario: La Intervención Pública sobre el Comercio Exterior de Bienes. 1aㅡ Ed. Madrid: Civitas, 1995.

- GARNER, B.A. Black's Law Dictionary. Seventh edition., St. Paul, Minn, U.S.A West group, 1999.

- GARRE, F. "Importación, mercancía, territorio". En: GARRE,F. MARQUEZ, A. MUÑOZ, F. VICENTE, B. SANCHEZ, I. Estudios aduaneros. $1^{\text {a }}$ Ed. Madrid: IEF, 1974,

- GaRRE, F. El hecho imponible en el impuesto aduanero. $1^{a}$ Ed. México: Centro De Investigación Aduanera y de Comercio Internacional, 1999.

- GIANNINI, A.D. Instituciones de Derecho Tributario. Traducido por SAINZ DE BUJANDA, F. 1르 Ed. Madrid: Editorial de Derecho financiero, 1957.

- GIFFONI, M. Droit Dounaier de la C.E. Et aspects economiques. $1^{\circ} \mathrm{Ed}$. Luxemburgo: Oficina de publicaciones oficiales de las Comunidades Europeas, 1993.

- GONZÁlez ALONSO, L.N. "Política comercial común". En: LÓPEZ ESCUDERO, M. MARTÍN Y PÉREZ DE NANCLARES, J. y OTROS. Derecho comunitario material. 1를. Madrid: Mc. Graw Hill, 2000.

- GONZÁleZ GARCíA, E. Y LEJEUNE, E. Derecho Tributario I. 2a Ed. Salamanca: Plaza Universitaria Ediciones, 2000.

- GORMLEY, L.W. EU law of free movement of goods and customs Union. $1^{\circ}$ Ed.New York: Oxford UniversityPress, 2009.

- GRECO, O. Diccionario de Economía. $3^{a}$ Ed. Buenos Aires Argentina: Valleta ediciones, 2006. 
- IBAÑEZ MARCILLA, S. "Tributos Aduaneros". En: CAYON GALIARDO, A.; MARTÍN QUERALT, J.; y TEJERIZO LOPEZ, J.M. (Directores). Manual de Derecho Tributario parte especial. $2^{a}$ Ed. Navarra: Thomson Aranzadi, 2004.

- INAMA, S. y VERMULST, E. Customs and Trade Laws of the European Community. Londres: The Hague, 1999.

- INSTITUTO DE INVESTIGACIONES JURÍDICAS. Enciclopedia jurídica mexicana. Tomo I. 1ª Ed. México: Porrúa - UNAM, 2002.

- JARACH, D. El hecho imponible teoría general del derecho tributario sustantivo. 3a Ed. Buenos Aires: Abeledo-Perrot, 1982.

- JIMÉNEZ GONZÁLEZ, A. Curso de derecho tributario. $1^{a}$ Ed. México: Tax editores, 2014.

- KELSEN, H. Teoría Pura del Derecho. VERNENGO, R.J. (traductor). $7^{a}$ Ed. México: Porrúa, 1993.

- KLAUS-DIETER BORCHARDT. El ABC del Derecho Comunitario.5 ed. Luxemburgo: Oficina de Publicaciones Oficiales de las Comunidades Europeas, 2000.

- LABAND, P. Le droit public de L'empire Allemand, Tome VI, Et Dernier Les Finances de l'Empire allemand. LARNAUDE, F. (Prol.) ; BOUYSSY (Trad.). 5a Ed. Paris : V. Giard \& E. Briere Libraires - éditeurs, 1904.

- LAGO MONTERO, J.M. Comentario a la Ley de Tasas y Precios públicos de la Comunidad de Castilla y León. 1르 Ed. Madrid: Dykinson, S.L. 2005.

- LASOK, D. The Trade and Custmos Law of the Europan Union. $3^{\underline{a}}$ Ed. London: Kluwer Law, 1997

- LEITE DE CAMPOS, D. "O Mercado comum europeu e a instituçao de barreiras tarifarias ou comopensatorias". En TAVEIRA TORRES, $H$. Comercio internacional e tributaçao. 1ํ Ed. Sao Paulo: Qaurtier Latin, 2005.

- LEON C. P. y MARCONI SALVADOR. La contabilidad nacional: Teoría y métodos. 3르. Ed. QUITO: Ediciones ABYA-YALA, 1999. 
- $\quad$ INDE PANIAGUA, E. "Fines y medios de las Comunidades Europeas. Los derechos fundamentales en la Unión Europea".En: Políticas comunitarias. Madrid: Colex, 2001.

- LINAN NOGUERAS, D. Instituciones y Derecho de la Unión Europea. $3^{a}$ Ed. Madrid: Tecnos, 2003.

- LÓPEZ ESCUDERO, M. "El mercado interior: cuestiones generales". En: LÓPEZ ESCUDERO, M. MARTÍN Y PÉREZ DE NANCLARES, J. y OTROS. Derecho comunitario material. $1^{\underline{a}}$ Ed. Madrid: Mc. Graw Hill, 2000.

- LUX, M. Guide to Community Customs Legislation. 1ํ Ed. Brussels: Bruylant, 2002.

- LyONS, T. EC Customs Law. $1^{\circ}$ Ed. New York: Oxford University Press, 2005.

- MANGAS maRTín, A.; LIÑAN NOGUERAS, D. Instituciones y Derecho de la Unión Europea. 3를 Ed, Madrid: Tecnos, 2003

- MARIENHOFF, M.S. Tratado de Derecho administrativo. Tomo V. Dominio Público. $4^{a}$ Ed. Buenos Aires: Abeledo-Perrot, 1998.

- MÁRQUEZ ROMERO, R. Nuevo diccionario jurídico mexicano, Tomo D-H. 1 Ed. México: Instituto de Investigaciones Jurídicas, Universidad Nacional Autónoma de México, 2000.

- MÁRQUEZ Y MÁRQUEZ, A. Renta de Aduanas. 1aㅡ. Md. Madrid: EDERSA, 1979.

- MARTIN E.A. Dictionary of law.Fourth edition. Great Britain: Oxford University Press, , 1997.

- martín queRARLT,J. LOZANO CeRRANO, C. y OtRos. Curso de derecho financiero y tributario. 13를 $\mathrm{Ed}$. Madrid: Tecnos, 2002.

- MARTÍN Y PÉREZ DE NANCLARES, J. "Las competencias comunitarias". En: LÓPEZ ESCUDERO, M. MARTÍN Y PÉREZ DE NANCLARES, J. y OTROS. Derecho comunitario material. 1를. Ed. Madrid: Mc. Graw Hill, 2000. 
- MARTÍNEZ MORALES, R. Derecho administrativo 3er. Y $4^{\circ}$ Cursos. $4^{a}$ ED. México: Oxford, 2005.

- MARTÍNEZ MORALES, R.I. Diccionarios jurídicos temáticos. Derecho administrativo. 2 ${ }^{\underline{a}}$ Ed. México: Oxford UniversityPress, 2000.

- MATTERA, A. El mercado único europeo sus reglas, su funcionamiento. $1^{\underline{a}}$ Ed. Madrid: Civitas, 1991.

- MissionáRIO,T. "Divida aduaneira". En: NUNO DA ROCHA, A. (Coordinador). Direito Aduaneiro das Comunidades Europeias: na perspectiva Uniao Europeia-Estudos. Braga: Barbosa \& Xavier, 1992.

- NAVA negrete, a. quiRoz acosta, E. "Bienes de dominio público". En: INSTITUTO DE INVESTIGACIONES JURÍDICAS. Enciclopedia jurídica mexicana. Tomo I. 1aㅡ Ed. México: Porrúa - UNAM, 2002.

- OTto MAYER. Derecho Administrativo Alemán. Tomo III Parte especial. El Derecho de las cosas públicas. HEREDIA, H. y KROTOSCHIN, E (Traductores). 1aㅡ. Ed. Buenos Aires: Editorial Depalma, 1951

- paRADA, R. Derecho Administrativo III Bienes públicos. Derecho urbanístico. 20aㅡ Ed. Madrid: Marcial Pons, 2010.

- pastor RIDRUEJo, J. A. Curso de Derecho Internacional Público y Organizaciones Internacionales. 9 ${ }^{\underline{a}}$ Ed. Madrid: Tecnos, 2003.

- PELECHA ZOZAYA, F. El Código Aduanero Comunitario y su aplicación en España. ${ }^{a}$ Ed. Madrid, Marcial Pons, 1995.

- PELEChA ZOZAYA, F. Fiscalidad sobre el Comercio exterior: el Derecho aduanero tributario. $1^{a}$ Ed. Madrid: Marcial Pons, 2009.

- quiNTANA VALTIERRA, J. y ROJAS YÁÑEZ, J. Derecho tributario mexicano. 5 $5^{\underline{a}}$ Ed. México: Trillas, 2008.

- RAMíreZ GUtiÉRREZ, J.A. "Decomiso". En: MÁRQUEZ ROMERO, R. Nuevo diccionario jurídico mexicano, Tomo D-H. $1^{\text {a }}$ Ed. México: Instituto de Investigaciones Jurídicas, Universidad Nacional Autónoma de México, 2000. 
- RAMÍREZ, F. "El poder judicial federal, defensor de la constitución". En: Derecho Constitucional Mexicano. 20를. México: Porrúa, 1984.

- RAPOSO DE MADEIROS, E. O dereito aduaneiro sua vertente internacional. Lisboa: Instituto superiores de ciências sociais y políticas, 1985.

- RHODE PONCE, A. Derecho aduanero mexicano 2. Regímenes, contribuciones y procedimientos aduaneros. $1^{\underline{a}} \mathrm{Ed}$. México: Ediciones fiscales ISEF, 2009.

- RODRÍGUEZ ZAPATA, J. Constitución, Tratados Internacionales y Sistema de Fuentes del Derecho. 1를. Bd. Bolonia: Real Colegio de España, 1976.

- RODRÍGUEZ LOBATO, R. Derecho fiscal. 2ª Ed. México: Oxford, 2005

- SÁENZ DE SANTA MARIA, P.A.; GONZÁLEZ VEGA, J.A. y FÉRNÁNDEZ PÉREZ, B. Introducción al Derecho de la Unión Europea. Madrid: Eurolex, 1996.

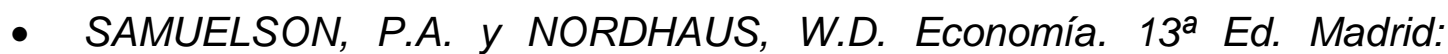
McGraw Hill, 1990.

- SECRETARÍA general COMUNIDAD ANDINA. "Comunidad Andina Unión Europea análisis de regímenes y aspectos aduaneros". Documentos informativos. 24 de agosto de 2009.

- SepulvedA, C. Curso de Derecho Internacional Público. $3^{a}$ Ed. México: Porrúa, 1968.

- SERRA ROJAS,A. Derecho administrativo, segundo curso. 25를. México: Porrúa, 2008.

- SIMPSON, J.A.; WEINER E.S.C. The Oxford English dictionary. 2a Ed. Oxford. U.K.: Oxford University Press, 1991.

- TENA RAMíREZ, F. "El poder judicial federal, defensor de la constitución". En: Derecho Constitucional Mexicano. 20ª Ed. México: Porrúa, 1984.

- tREJO garcía, E.C. Sistema de Recepción de los Tratados Internacionales en el Derecho Mexicano. México: Centro de 
Documentación, Información y Análisis, Dirección de Servicios de Investigación y Análisis, Subdirección de Política Exterior, 2006.

- VICENTE, B. SANCHEZ, I. Estudios aduaneros. 1a Ed. Madrid: IEF, 1974.

- VORK, R. Y KATtENBUSCH, W. "La Gestión Arancelaria En La Comunidad Europea". En: La Modernización de la Gestión Aduanera en los Procesos de Integración Regional. Uruguay: Centro de Formación para la Integración Regional, 1993.

- WITKER, J. y PEREZ NIETO, L. Aspectos jurídicos del Comercio Exterior en México. 2ª Ed. México: Editorial Nueva Imagen, 1980.

- WITKER,J. Derecho tributario aduanero. 2a Ed. México: UNAM, Instituto de Investigaciones Jurídicas, 1999.

- World Customs Organization. Glossary of international customs terms. Brussels, 2013. 


\section{REVISTAS}

- aldREte VARGAS, A. "El control constitucional en México". Sufragio, Revista especializada en Derecho electoral. Publicación del Tribunal Electoral del Poder Judicial del Estado de Jalisco. 3ª́ Época, Vol. 1, Núm. 1, año 2008.

- Álvarez gómez PAllete, J.M. "Aspectos aduaneros de la política agrícola común". Aduanas. Revista de comercio internacional y estudios fiscales. 1985.

- AZPITARTE SÁNCHEZ, M. Revista de Derecho constitucional europeo. № 5, Enero-Junio de 2006, 11-30.

- $\quad B E R L I R I$, A. “La obligación tributaria aduanera”. Aduanas. 272 -273.

- berzosa, C. "Mercado, Estado y Economía Mundial". Revista de Economía Mundial. 1999.

- BONET MARCO, E. "El arancel aduanero de las CEE (Sistema armonizado, nomenclatura combinada y TARIC) ". Noticias CEE. 1991. № 79 -80.

- CORTÉS DOMÍNGUEZ, M. "Introducción al Derecho aduanero". Aduanas $N^{\underline{a}} 160,161$ y 166.1967

- DIRECCIÓN GENERAL DE ADUANAS E IMPUESTOS ESPECIALES. "La deuda aduanera”. Aduanas informa sobre Comunidades Europeas. № 31 (mayo - junio 1989)

- DURBAN ACIEN, J. "Sistema aduanero". En: Aduanas Informa. Núm. 77, abril-junio 1998

- ferullo, H. El Estado, el mercado y el proceso deliberativo de la sociedad civil. Revista Valores en la Sociedad Industrial. 2005, № 63

- GALARZA, C. "Tributación y actos ilícitos: ¿existen trabas éticas o morales para la tributación de los actos ilícitos?". Dereito: Revista xuridica da Universidade de Santiago de Compostela. Vol. 15, N², 2006. 
- GaRCÍA tRUJILLO, S. "Acuerdo general sobre Aranceles Aduaneros y Comercio (GATT). Exposición crítica y valoración global". Noticias de la Unión Europea. 1994. № 115 - 116.

- GARCIA, T. y RÍOS, G. "Diferencias entre impuestos aduaneros de importación y cuotas compensatorias del comercio exterior mexicano, en el ámbito del derecho tributario. Reflexiones sobre la constitucionalidad de las mismas". Boletín mexicano de derecho comparado. Número 91 Enero-Abril 1998.

- GOGUEL, F. "Le classement tarifaire des appareils á fonctions multiples". Revue des Affaires Européennes, Law\&EuropeanAffairs. № 4. 2005.

- GONZÁlez GARCÍA, E. "Derecho Fiscal, Derecho financiero y Hacienda Pública Revista de Derecho Financiero y Hacienda Pública", en Revista de Derecho Financiero y Hacienda Pública, № 104, 1973.

- GONZÁlez GRAJERA, F. "Novedades en el procedimiento de gestión aduanera". Aduanas. № 354, 1986.

- häBERLE, P. "Siete tesis para una teoría constitucional del mercado". Traducido del alemán por AZPITARTE SÁNCHEZ, M. Revista de Derecho constitucional europeo. № 5, Enero-Junio de 2006, 11-30.

- JESSOP, B. ¿Narrando el futuro de la economía nacional y el estado nacional? Puntos a considerar acerca del replanteo de la regulación y la reinvención de la gobernancia. Documentos y Aportes en Administración Pública y Gestión Estatal. 2006, № 7.

- MÁRQUEZ Y MÁRQUEZ, A. "El Derecho aduanero español: su aproximación e integración en el Derecho aduanero europeo". Revista española de Derecho Financiero, número 10, Madrid, Civitas, abril/junio 1976.

- PHILIPPE, B. "Los escenarios jurídicos de los frentes aduaneros (origen, valor en aduana, nomeclatura, arancel)". Traducido por DE PABLO VARONA, C. Quincena fiscal. № 12, Junio 2006. 
- RENOUE, J.C. "Le tarif douanier commun". Revuefrançaise de finances publiques, 1983, no 3 .

- SÁNCHEZ GONZÁLEZ, I. "La deuda aduanera”. Noticias/ C.E.E. 1991, № 79/80, P. 109.

- SÁNCHEZ, I. "El hecho imponible del impuesto aduanero". Aduanas. 1968, № 174.

- TORRENT, R. "El futuro de la Unión Europea visto desde sus entrañas, la Unión aduanera". En Revista española de Derecho Europeo, № 4, Octubre -Diciembre 2002

- vanestralen, H. "bienes de titularidad pública: patrimoniales y de dominio público. Una aproximación al sistema español". Estudios SocioJurídicos. Bogotá, Colombia, № 6 (enero-junio de 2004). 


\section{CIBERGRAFIA}

- "Régimen común aplicable a las importaciones". En: Síntesis de legislación de la UE. Disponible en: http://europa.eu/legislation summaries/external trade/r11002 es.htm

- "Régimen comunitario de franquicias aduaneras". En: Síntesis de legislación de la UE. Bruselas: Oficina de publicaciones Oficiales de la Comisión, Ultima actualización 06.01.2006, Fecha de consulta: 06/09/2011. Disponible en: http://europa.eu/legislation_summaries/customs/l11002_es.htm.

- Asociación Latinoamericana de Integración. Glosario. [En línea] Fecha Consulta: 18/05/2011. Disponible en web: http://www.aladi.org/nsfaladi/vbasico.nsf/valfaweb/a

- “Código aduanero comunitario". Síntesis de legislación de la UE. Última modificación: 16.12.2005. En el Link: http://europa.eu/scadplus/leg/es/lvb/l11010.htm

- Comisión Europea. Trade Glosary. Disponible en: http://ec.europa.eu/trade/glossary.

- DE FRANCISCO, V. Contingentes arancelarios y contingentes cuantitativos: rebajas y veda en el comercio internacional [En línea]. Fecha publicación: 14/05/2004. Fecha Consulta: 18/05/2011. Disponible en web: http://www.comercio-exterior.es/es/action-articulos.articulos+art-78+cat$\underline{10+p a g-}$

$\underline{2 / A r t i c u l o s}+d e+$ comercio + exterior/Aduanas/Contingentes+arancelarios $+y+c$

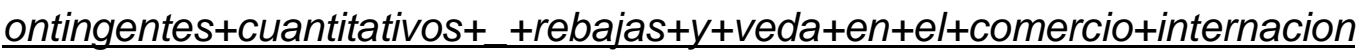
al.htm

- Diccionario de la Real Academia de la Lengua Española. http://buscon.rae.es 
- Dirección General de Aduanas de México [Consultada el 07 de agosto de 2014], en el sitio: http://www.aduanas.gob.mx/aduana mexico/2008/quienes somos/138 100 19.html

- encIClOPEDIA BRITANICA. "Market". En: Britannica Online Encyclopedia. http://www.britannica.com/EBchecked/topic/365647/market.

- FERUllo, H. El Estado, el mercado y el proceso deliberativo de la sociedad civil. Revista Valores en la Sociedad Industrial. 2005. Disponible en web: hittp://dialnet.unirioja.es/servlet/articulo?codigo=1309101.

- GARRIGUES. Boletín Aduanas. Madrid, Junio 2008. Disponible en web: http://www.garriguesmedioambiente.com/doc/AreaComunicacion/Publicacio nes/Novedades/Boletines/Boletin Aduanas 106200817062008120412. pdf

- Lutateoriaeconomica. 03-06-2008Teoría Económica. Diagrama obtenido de la página web: http://iutateoriaeconomica.blogspot.es/

- La política comercial común. Síntesis de la legislación de la UE. En el link: http://europa.eu/scadp/us/leg/es/lvb/a20000.htm

- olga sánchez cordero de garcía Villegas. "Reforma CONSTITUCIONAL DE DERECHOS HUMANOS: CASO ROSENDO RADILLA PACHECO". Disponible en la página web: https://www.scjn.gob.mx/conocelacorte/ministra/conferencia20111110.pdf

- Organización Mundial de Comercio. Glosario de términos. [En línea] Fecha Consulta: 18/05/2011. Disponible en web: https://www.wto.org/spanish/thewto s/glossary s/glossary s.htm 
comparado"

- Organización Mundial del Comercio. Información técnica sobre salvaguardias.

Disponible

en:

http://www.wto.org/spanish/tratop s/safeg s/safeg info s.htm

- Recursos propios. Síntesis de legislación de la UE. Última modificación: 04.09.2007. Consultada 20/08/2010. En el link: http://europa.eu/legislation summaries/budget//34011 es.htm

- Secretaría de Economía del Gobierno de la Republica. Países con Tratados y Acuerdos firmados con México. Consultado el 14/07/14, en la dirección electrónica: http://www.economia.gob.mx/comunidad-negocios/comercioexterior/tlc-acuerdos .

- SILVA HERZONG, J. "El Comercio de México durante la época colonial". Memorias del Colegio Nacional. Disponible en web: http://www.colegionacional.org.mx/SACSCMS/XStatic/colegionacional/templ ate/pdf $/ 1956 / 05 \% 20 \% 20$ Ciencias\%20Economicas\%20y\%20Sociales $\% 20$ E 1\%20comercio\%20de\%20Mexico\%20durante\%20la\%20epoca\%20colonial\% 20por\%20Jesus\%20Silva\%20Herzog.pdf.

- Suprema Corte de Justicia de la Nación. Acuerdo General Plenario. AnexoAGP_9_11. Disponible en la página web: https://www.scin.gob.mx/libreria/Documents/AcuerGralesJurisdicPermVig/A nexo-AGP 9 11.pdf

- VICTOR DE FRANCISCO. "contingentes arancelarios y contingentes cuantitativos: rebajas y veda en el comercio internacional". Disponible en

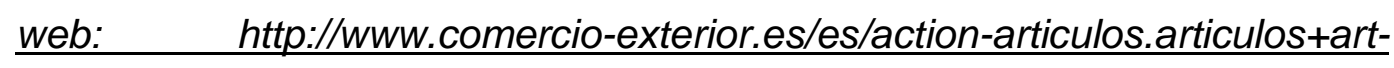
$\underline{78+\text { cat }-10+\text { pag- }}$

/Articulos $+d e+$ comercio+exterior/Aduanas/Contingentes+arancelarios $+y+c 0$ ntingentes+cuantitativos+ +rebajas+y+veda+en+el+comercio+internacional. $\underline{h t m}$ 
Carlos Gerardo Herrera Orozco $\quad 354$

“El nacimiento de la deuda aduanera en la Unión Europea y México. Estudio comparado" 


\section{JURISPRUDENCIA}

\section{TRIBUNAL DE JUSTICIA DE LA UNIÓN EUROPEA}

SENTENCIAS

\begin{tabular}{|c|c|}
\hline & FECHA \\
\hline ASUNTO(S) & SENTENCIA \\
\hline C-6/64 & $15 / 07 / 1964$ \\
\hline C-2/69 Y C-3/69 & $01 / 07 / 1969$ \\
\hline C-8/73 & $27 / 06 / 1973$ \\
\hline C-37 Y 38/73 & $13 / 12 / 1973$ \\
\hline C-1/75 & $11 / 11 / 1975$ \\
\hline C-41/76 & $15 / 12 / 1976$ \\
\hline C-106/77 & $09 / 03 / 1978$ \\
\hline C-170/78 & $27 / 02 / 1980$ \\
\hline C-15/81 & $05 / 05 / 1981$ \\
\hline C-184/1981 & $16 / 11 / 1981$ \\
\hline C-186 Y 187/82 & $05 / 10 / 1983$ \\
\hline C-174/84 & $18 / 02 / 1986$ \\
\hline
\end{tabular}


Carlos Gerardo Herrera Orozco

\begin{tabular}{|c|c|}
\hline C-45/86 & $26 / 03 / 1987$ \\
\hline C-356/85 & $09 / 07 / 1987$ \\
\hline C-165/87 & $27 / 09 / 1988$ \\
\hline C-111/92 & $02 / 08 / 1993$ \\
\hline C-1/94 & $15 / 11 / 1994$ \\
\hline C-125/1994 & 05/10/1995 \\
\hline C-238/95 & $14 / 03 / 1996$ \\
\hline C-3/97 & $28 / 05 / 1998$ \\
\hline C-3/97 & $28 / 05 / 1998$ \\
\hline C-283/95 & $11 / 06 / 1998$ \\
\hline C-158/98 & $29 / 06 / 1999$ \\
\hline C-455/98 & $29 / 06 / 2000$ \\
\hline C-455/98 & $29 / 07 / 2000$ \\
\hline C-371/99 & $11 / 07 / 2002$ \\
\hline C-30/01 & $23 / 09 / 2003$ \\
\hline C-337/01 & $12 / 02 / 2004$ \\
\hline C-338/01 & $29 / 04 / 2004$ \\
\hline C-222/01 & $29 / 04 / 2004$ \\
\hline C-338/01 & $29 / 04 / 2004$ \\
\hline
\end{tabular}


Carlos Gerardo Herrera Orozco

\begin{tabular}{|c|c|}
\hline C-300/03 & $20 / 01 / 2005$ \\
\hline C-195/03 & $03 / 03 / 2005$ \\
\hline C-484/03 & $12 / 01 / 2006$ \\
\hline $\begin{array}{c}\text { C-354/03 acumulados C- } \\
355 / 03 \text { y C- } 484 / 03\end{array}$ & $12 / 01 / 2006$ \\
\hline $\begin{array}{c}\text { C-439/04 y acumulado C- } \\
440 / 04\end{array}$ & 06/06/2006 \\
\hline C-467/04 & $15 / 06 / 2006$ \\
\hline C-459/07 & $02 / 04 / 2009$ \\
\hline C-410/08 Y & \\
\hline ACUMULADOS & 17/12/2009 \\
\hline C-410/08 & $17 / 12 / 2009$ \\
\hline C-230/08 & $29 / 04 / 2010$ \\
\hline C-230/08 & $29 / 04 / 2010$ \\
\hline C-248/09 & $29 / 07 / 2010$ \\
\hline C-213/09 & $25 / 11 / 2010$ \\
\hline C-262/10 & $06 / 09 / 2012$ \\
\hline C-273/12 & $11 / 07 / 2013$ \\
\hline C-75/13 & $12 / 06 / 2014$ \\
\hline C-28/11 & 06/09/20012 \\
\hline
\end{tabular}


Carlos Gerardo Herrera Orozco 358 "El nacimiento de la deuda aduanera en la Unión Europea y México. Estudio comparado"

\begin{tabular}{|l|l|}
\hline C-533/10 & $14 / 06 / 20012$ \\
\hline
\end{tabular}




\section{CONCLUSIONES ABOGADO GENERAL}

\begin{tabular}{|c|c|}
\hline Asunto & Fecha \\
\hline C-8/73 & $27 / 06 / 1973$ \\
\hline C-459/07 & $04 / 11 / 2008$ \\
\hline C-467/04 & $15 / 06 / 2006$ \\
\hline C-195/03 & $30 / 09 / 2004$ \\
\hline C-314/06 & $18 / 07 / 2007$ \\
\hline
\end{tabular}


\begin{tabular}{l|l} 
Carlos Gerardo Herrera Orozco & 360
\end{tabular} comparado"

\section{TRIBUNAL DE JUSTICIA DE PRIMERA INSTANCIA DE LA COMUNIDAD EUROPEA}

\begin{tabular}{|c|c|}
\hline Asunto & Fecha sentencia \\
\hline T-115/94 & 22-ene-97 \\
\hline
\end{tabular}



comparado”

\section{TRIBUNAL CONSTITUCIONAL ESPAÑOL}

\begin{tabular}{|c|c|}
\hline Fecha sentencia & asunto \\
\hline $16 / 11 / 1981$ & $184 / 1981$ \\
\hline $29 / 11 / 1988$ & $227 / 1988$ \\
\hline $14 / 12 / 1995$ & $185 / 1995$ \\
\hline
\end{tabular}




\section{PODER JUDICIAL DE LA FEDERACIÓN (MÉXICO)}

\begin{tabular}{|c|c|c|}
\hline Tipo & Época & registro \\
\hline Jurisprudencia & $10 a$ & 2007408 \\
\hline Jurisprudencia & $10 a$ & 2002128 \\
\hline Jurisprudencia & $10 a$ & 2002246 \\
\hline Jurisprudencia & $10 a$ & 2005184 \\
\hline Jurisprudencia & $10 a$ & 2006224 \\
\hline Jurisprudencia & $10 a$ & 2006808 \\
\hline Jurisprudencia & $10 a$ & 2001705 \\
\hline Jurisprudencia & $7 a$ & 232308 \\
\hline Jurisprudencia & $8 a$ & 205596 \\
\hline Jurisprudencia & $8 a$ & 389668 \\
\hline Jurisprudencia & $9 a$ & 165045 \\
\hline Jurisprudencia & $9 a$ & 165006 \\
\hline Jurisprudencia & $9 a$ & 164509 \\
\hline Jurisprudencia & $9 a$ & 165045 \\
\hline Jurisprudencia & $9 a$ & 166883 \\
\hline
\end{tabular}




\begin{tabular}{|c|c|c|}
\hline Jurisprudencia & $9 a$ & 167414 \\
\hline Jurisprudencia & $9 a$ & 171828 \\
\hline Jurisprudencia & $9 a$ & 175077 \\
\hline Jurisprudencia & $9 a$ & 189109 \\
\hline Jurisprudencia & $9 a$ & 189110 \\
\hline Jurisprudencia & $9 a$ & 189172 \\
\hline Jurisprudencia & $9 a$ & 190669 \\
\hline Jurisprudencia & $9 a$ & 191360 \\
\hline Jurisprudencia & $9 a$ & 192849 \\
\hline Jurisprudencia & $9 a$ & 173020 \\
\hline Jurisprudencia & $9 a$ & 167856 \\
\hline Jurisprudencia & $9 a$ & 169484 \\
\hline Tesis & $9 a$ & 192867 \\
\hline
\end{tabular}


TRIBUNAL FEDERAL DE JUSTICIA FISCAL Y ADMINISTRATIVA (ANTES TRIBUNAL FISCAL DE LA FEDERACIÓN) MÉXICO

\begin{tabular}{|l|l|}
\hline \multicolumn{1}{|c|}{ Tipo } & \multicolumn{1}{|c|}{ Época } \\
\hline $\begin{array}{l}\text { Jurisprudencia Plenaria de } \\
\text { fecha16 de noviembre de } \\
1937\end{array}$ & \\
\hline
\end{tabular}




\section{LEGISLACIÓN}

\section{UNIÓN EUROPEA}

Acto del Consejo de 18 de Diciembre de 1997 (98/c/24/01)

Código Aduanero Comunitario

Código Aduanero de la Unión

COM final 2010608 de fecha 27 de Octubre de 2010. Hacia un Acta del Mercado Único.

Comunicación de la Comisión 2003/C 103/01 de fecha 30 de abril de 2003

Comunicación de la Comisión 2003/C-103/01 de 30 de abril de 2003

Decisión del Consejo de 07 de Junio de 2007 (2007/436/CE,EURATOM)

Directiva 112/2006

Directiva 118/2008

Directiva $88 / 2010$

Nota de prensa del TJCE 57/99

Opinión del Parlamento Europeo PE 364.661v01-00, Asunto: "Fundamento jurídico de la propuesta de Directiva del Consejo relativa a medidas comunitarias de lucha contra la influenza aviar (COM(2005)0171 -C6 0195/2005 2005/0062(CNS))"

Reglamento 1225/2009 
Reglamento 1416/1995

Reglamento 1864/2004

Reglamento 215/2000

Reglamento 2454/1993

Reglamento 2505/92

Reglamento 260/2009

Reglamento 2658/1987 (Nomenclatura Arancelaria)

Reglamento 2913/1992 (Código Aduanero)

Reglamento 3665/1993

Reglamento 450/2008 (Código Aduanero Modernizado)

Reglamento 493/2005

Reglamento 82/1997

Reglamento 838/2006

Reglamento 918/1983

Reglamento 948/2009

Reglamento 950/1968

Reglamento 952/2013 (Código aduanero de la Unión)

Tratado CECA (1951) 
Tratado de Amsterdam (1997)

Tratado de Funcionamiento de la Unión Europea

Tratado de Lisboa (2007)

Tratado de Roma (1957) C.E.E

Tratado de Roma (2004) Constitución Europea

Decisión del Consejo 93/329/CEE 


\section{ESTADOS MIEMBROS DE LA UNIÓN EUROPEA}

Constitución Española

Ley General Tributaria (España)

Lei Geral Tributaria (Portugal)

Code des dounes national (Francia)

Real Decreto 1299/86

Ley Orgánica 6/2011 de 30 de junio de 2011 (España).

Ley Orgánica 12/1995 de 12 de Diciembre 


\section{ESTADOS UNIDOS MEXICANOS}

Decreto que establece la devolución de impuestos de importación a los exportadores. De fecha 29 de Diciembre del 2000

Código Aduanero (Abrogado)

Código Fiscal de la Federación

Constitución Política de los Estados Unidos Mexicanos

Constitución Política de los Estados Unidos Mexicanos 1857

Ley Aduanera

Ley de Comercio Exterior

Ley Federal de Derechos

Ley General de los Impuestos Generales a la Importación y Exportación

Ley Reglamentaria del artículo 131 de la Constitución Política de los Estados Unidos Mexicanos (Abrogada) 


\section{ACUERDOS CONJUNTOS UNIÓN EUROPEA - MÉXICO}

Acuerdo de Asociación Económica, Concertación Política y Cooperación entre los Estados Unidos Mexicanos y la Comunidad Europea y sus Estados Miembros, la Decisión del Consejo Conjunto de dicho Acuerdo; y la Decisión del Consejo Conjunto del Acuerdo Interino sobre Comercio y Cuestiones Relacionadas con el Comercio entre los Estados Unidos Mexicanos y la Comunidad Europea

ANEXO III del TLC México - Comunidad Europea

Decisión 2/2000 del Consejo Conjunto Comunidad Europea - México 


\section{TRATADOS, CONVENCIONES Y PROCEDIMIENTOS}

\section{INTERNACIONALES}

Convención de Viena sober el derecho de los Tratados de 1969

Acuerdo General Ronda de Uruguay de la Organización Mundial de Comercio.

Acuerdo General sobre comercio y aranceles aduaneros 1947 (G.A.T.T.)

Anexos E y B del Convenio de Estambul.

Capítulo 2 del Anexo General de la Convención de Kyoto

Convenio Internacional de Estambul relativo a la importación temporal de 26 de Junio de 1990 .

Convenio Internacional sobre el Sistema Armonizado de Designación y Codificación de mercancías, hecho en Bruselas el 14 de junio de 1983, y su protocolo de enmienda, hecho en Bruselas el 24 de junio de 1986.

Entendimiento relativo a la interpretación del artículo XXIV del Acuerdo General sobre comercio y aranceles aduaneros de 1994

RONDA DE URUGUAY. Acuerdo sobre la Agricultura. Parte III Solicitud de Solución de Diferencias ante la OMC expediente DS 315 